\title{
De invloed van klasse, status en burgerschap op subjectieve gezondheid
}

Citation for published version (APA):

Joosten, J. (1995). De invloed van klasse, status en burgerschap op subjectieve gezondheid. [Doctoral Thesis, Maastricht University]. Datawyse / Universitaire Pers Maastricht.

https://doi.org/10.26481/dis.19950407jj

Document status and date:

Published: 01/01/1995

DOI:

10.26481/dis.19950407jj

Document Version:

Publisher's PDF, also known as Version of record

\section{Please check the document version of this publication:}

- A submitted manuscript is the version of the article upon submission and before peer-review. There can be important differences between the submitted version and the official published version of record.

People interested in the research are advised to contact the author for the final version of the publication, or visit the DOI to the publisher's website.

- The final author version and the galley proof are versions of the publication after peer review.

- The final published version features the final layout of the paper including the volume, issue and page numbers.

Link to publication

\footnotetext{
General rights rights.

- You may freely distribute the URL identifying the publication in the public portal. please follow below link for the End User Agreement:

www.umlib.nl/taverne-license

Take down policy

If you believe that this document breaches copyright please contact us at:

repository@maastrichtuniversity.nl

providing details and we will investigate your claim.
}

Copyright and moral rights for the publications made accessible in the public portal are retained by the authors and/or other copyright owners and it is a condition of accessing publications that users recognise and abide by the legal requirements associated with these

- Users may download and print one copy of any publication from the public portal for the purpose of private study or research.

- You may not further distribute the material or use it for any profit-making activity or commercial gain

If the publication is distributed under the terms of Article $25 \mathrm{fa}$ of the Dutch Copyright Act, indicated by the "Taverne" license above, 


\section{DE INVLOED VAN KLASSE, STATUS EN BURGERSCHAP OP SUBJECTIEVE GEZONDHEID}

Ter nagedachtenis aan mijn vader. Jan (Johannes Petrus) Joosten 
CIP DATA KONINKLLIAKE BIBLIOTHEEK, DEN HAAG

Jarn doosten

De invloed van klase, status en burgerschap op subjectieve gezondhaid / Jam Joosten. - Meastricht : Uniwersitaire Pers Maastricht. - III., schema's, tab.

Proefschrift Aijksuniversitelt Limburg Maastricht. - Met lit. opg. , reg.

ISBN 90-5278-180-X.

Trefw: gezondheld; sociaal-economische aspecten / epidemiologie / medische sociologie.

Boekproduktie: Datawyse I Universitaire Pers Maastricht 


\title{
DE INVLOED VAN KLASSE, STATUS EN BURGERSCHAP OP SUBJECTIEVE GEZONDHEID
}

\author{
PROEFSCHRIFT
}

ter verkrijging van de graad van doctor, aan de Rijksuniversiteit Limburg te Maastricht, op gezag van de rector magnificus Prof. Mr. M.J. Cohen, volgens het besluit van het College van Decanen

in het openbaar te verdedigen op vrijdag 7 april 1995 om 14.00 uur

door

JAN JOOSTEN

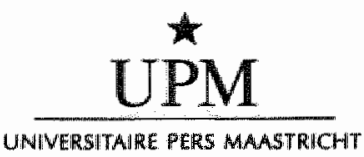




\section{Promotor:}

Prof. Dr. M.J. Drop

Beoordelingscommissie:

Prof. Dr. A. Appels (voorzitter)

Prof. Dr. J.P. Mackenbach (Erasmus Universiteit Rotterdam)

Dr. M. Mootz (Sociaal Cultureel Planbureau)

Prof. Dr. G. de Vries

Prof. Dr. J. van der Zee

Een deel van dit onderzoek werd uitgevoerd in het kader van het Programma 'Sociaal-Economische Gezondheidsverschillen" en mogelijk gemaakt door een subsidie van het Ministerie van Welzijn, Volksgezondheid en Cultuur. Het CBS verleende toestemming om de gegevens van de leefsituatie-onderzoeken van 1974 tot 1983 te analyseren. 


\section{VOORWOORD}

Het onderwerp van dit proefschrift, verschillen in gezondheid tussen mensen wan verschillende rang en stand, lijkt bijkans een wat afgezaagd onderwerp. Bestaan er immers al niet sinds vele eeuwen duidelijke oordelen over waarom mensen in de lagere echelons van de samenleving ongezonder zijn dan die in de hogere regionen? Leiden de laatsten niet een gemakkelijk en gezond leven, en moeten de eersten niet in het zweet huns aanschilns hun karig dagelijks brood verdienen? Is het bovendien niet $z o$, dat over zaken als gezondheid en ziekte of leven en dood mensen zelf weinig zeggenschap hebben? is niet het merendeel van de West-Europese bevolking, door de werbeterde leefomstandigheden een lang leven beschoren, dat ze, dankzil de toegenomen kennis en kunde op medisch gebled, wrij lang leiden zonder geplaagd te worden door restverschijnselen van eerder doorgemaakte ziekten?

Al zou er een sociale gradiënt in gezondheid en ziekte bestaan, hoe zou deze zijn te beinvloeden? Gedrag is immers vooral cultureel verankerd en daarmee moeilijk bereikbaar voor verandering. ondanks voorlichtingscampagnes en rationele informatie.

Vanuit deze gezichtspunten moet je wel socioloog zijn om op dit gebied nog onderzoek te ondernemen. In de publieke opinie houdt hij zich immers bezig met vragen waar ieder het antwoord toch al op kent.

Toen in 1989 de mogelijkheid zich voordeed subsidie voor de hier verslaglen studie te verwerven bij de toenmalige Programmacommissie Sociaal-Economische Gezondheids-Verschillen (SEGV) lag mijn belangstelling niet bij het beschrijven van verschillen in gezondheid tussen de sociale lagen. Mijn primaire interesse voor dit onderwerp kwam voort uit de vraag, in welke mate onderscheiden begrippen voor sociale differentiatie een verklaring voor deze verschillen leveren. Met andere woorden, zijn de leefomstandigheden, waar indelingen in sociale klassen naar verwijzen, meer bepalend voor verschillen in gezondheid dan indelingen naar sociale status die eerder de verschillen in leefstijl verantwoordelijk achten, of zijn beide zo werstrengeld dat ze elkaars invloed teniet doen?

Bij de voarbereiding van de subsidie-aanvraag bleek in de literatuur over sociale differentiatie. dat onder invloed van het Tatcherisme naast klasse en status, ook burgerschap een verklaring biedt voor socialle gelaagdheid. Opgevat als de mate waarin men deell mag en kan hebben aan de samenleving, lijkt dit begrip een verbinding te leggen tussen kenmerken van hett individu, diens participatie in socilale netwerken en de maatschappelijke structuur en organisatie. Van sociale integratie wan het individu is de invloed op gezondheid beschreven, maar tot op heden ontbreekt een theorie die sociale participatie en kenmerken van netwerken verbindt met sociale differentiatie. De vraagstelling van dit onderzoek "de mate waarin de verschillende aspecten van sociale differentiatie gezondheid beïnvoeden, is dan ook verder theoretisch sociologisch dan praktisch of beleidsmatig gericht. Dit betekent evenwel niet dat de resultaten voor belleid niet relevant zijn.

In de afgelopen week is de Engelse regering door de Rowntree-foundation gewaarschuwd voor het verder laten groeien van de kloof tussen rijk en arm in die samenleving. Een verdergaande tweedeling van de samenleving zou contraproductief zijn en meer geld kosten dan het arm houden van de bevolking zou opbrengen. In Nederland blijkt in de discussies over 'paars' de vraag naar de plaats en functie van sociale zekerheid en van de gevaren van een mogelijke tweedeling in de samenleving opnieuw aan de orde te worden gesteld. Het onderwerp en de uitkomsten van deze studie likken daardoor actueler dan ik bij aanvang voor mogelijk hield.

Het schrijven van een proefschrift gebeurt enerzijds in volstrekte eenzaamheid en anderzijds voor het front van de wetenschap. Het lezen en bedenken wan een vraagstelling, wan analyses en het schrijven van een verslag wordt weliswaar alleen, achter boek, schrijf-, of rekentuig 
De invloed war klasse, status en burgerschap op subjectieve gezondheid

uitgevoerd, in de voorbereiding van deze activiteiten en in de gesprekken over de produkten ervan vinden de belangrijkste ontwikkelingen plaals. Mijn promotor Prof.Dr.M.J. Drop heeft herin een zeer belangrike rol gespeeld. Alet, in de vele gesprekken die we hebben gevoerd over deze en andere onderwerpen heb ik veel van je geleerd. Jouw nauwgezette lezing van min concepten en je voorstellen tot werbetering, hebben mij de zekerheid gegeven dat niet mijn gedachtenspinsels verbetering behoefden, maar dat de verpakking moest worden aangepast. Je hebt me geleerd om slechts eén onderwerp per zin te behandelen en in én alinea hooguit twee gedachten met elkaar te verbinden. Jouw voortdurende bereidheid om miln gedachtengang te volgen en de inconsistenties in redeneringen aan te wijzen, hebben me de zekerheid gegeven dat het de moeite waard was om deze onderneming door te zetten. In ieder geval heeft je begeleiding zijn doel, het maken van een consistent verhaal niet gemist. Zonder jouw voortdurende bemoediging en belangstelling had dit boek hier niet gelegen.

Dat het opschonen, controleren en op elkaar afstemmen van 5 CBS bestanden en het panelonderzoek de hele subsidie van de programma-commissie zou opslorpen, hadden noch ik noch mijn promotor in 1989 verwacht. Het zeer nauwgezette werk van Drs. John Mullink heeft in het latere stadium; toen ith zelf de verdere indexen moest maken en de analyses uitvoeren, zijn wuchten dubbel en dwars opgebracht. Daarbij was het een sport om op basis van de uitgevoerde analyses te kunnen zeggen, "John, er moeten toch nog een aantal foute coderingen in die en die variabele zitten!'.

Van de overige leden van de vakgroep verdient met name Dr.J.P.M. Diederiks bijzondere dank. Jos, bij jou kon ik op elk ongewenst ogenblik even binnervallen om een boom op te zetten over een sociologisch, methodologisch of statistisch probleem dat me op dat moment dwars zat. Daarnaast heb ik nuttig advies en commentaar gekregen voor de statistische verwerking van Drs. Lex Vollovich van de vakgroep Medische Informatica en Statistiek. In een eerder stadium heeft $\mathrm{Dr}$. Tj. Imbosch van dezelfde vakgroep de analyses kritisch bekeken. Fouten hierin blijven evenwel geheel mijn verantwoordelijkheid. De medewerkers van de systeemgroep van het ICA waren steeds bereid om mij meer schijfruimte te geven wanneer ik dacht dat nodig te hebben of om user81: of om een tape op de VAX te zetten.

Drs. M.A. Scholten s.s.t.t. heeft mij materieel en geestelijk gesteund als dat nodig was. Maria, je gekke invallen en grote belezenheid maken dat gesprekken met jou vele onverwachte en grappige wendingen nemen. Je nauwgezette lezing van de verschillende drukproeven hebben veel fouten uit de tekst gehaald. Dr. F.G.E.M. van der Hors! heeft op eenzelfde wijze maar doorgaans op andere tijdstippen, eenzelfde stimulierende rol vervuld. Frans, je woortdurende belangstelling voor de vorderingen van dit project, lieten me zien dat het onderwerp van dit boek niet geheel vanzelfsprekend is.

Wetenschap zou eigenlijk alleen door monniken moeten worden bedreven. Het lezen en verteren van literatuur, het bedenken van analyses en de interpretaties van hun uitkomsten, het bedenken van 'het verhaal', ziljn actiwiteiten die zich niet aan kantoortijden houden. Bety en Jasper hebben mij regelmatig moeten waarschuwen dat zij er ook nog waren en mijn aandacht verdienden. Ik hoop dat zij, nu het boek klaar is, deze onachtzaamheid kunnen begri]pen. In leder geval zal ik proberen in dit opzicht mijn leefstijl te beteren.

Pas in een heel laat stadium ben ik mij gaan realiseren dat de praktische consequenties van dit onderzoek: laat mensen in goede huizen wonen en onder menswaardige omstandigheden loven en werken, beheers jezelf, houd greep op je omgeving en laat je niet door anderen leven, en wees betrokken op anderen, mij zo bekend voorkwamen omdat zij mij door mijn ouders zijn voorgeleefd. Wellicht daarom weet ik ook dat het gemakkelijker is deze geboden op te schrijven dan consequent uit te voeren. Mijn vader vond in zijn geloof een fundament voor deze geboden. In deze studie komen ze in seculiere vorm terug. Daarom draag ik dit boek op aan de nagedachtenis van Jan (Johannes Petrus) Joosten. 
1 GEZONDHEIDSVERSCHILLEN ALS MAATSCHAPPELIJK VERSCHIJNSEL

1.1 Inleiding 13

1.2 De sociale gelaagdheid in de tweede helft van de $20^{\text {ste }}$ eeurw

$\begin{array}{ll}1.3 \text { Hedendaagse gezondheidsverschillen } & 17\end{array}$

$\begin{array}{ll}\text { 1.3.1 Epidemiologisch profiel } & 17\end{array}$

1.3.2 Het Black Report 18

1.3.3 Sociaal-economische gezondheidsverschillen in Nederland 19

1.3.4 Verklaringen voor sociaal-economische gezondheidsverschillen 20

1.4 Het onderhavige onderzoek 23

2 THEORETISCHE UITGANGSPUNTEN EN ONDERSTELLINGEN 27

$\begin{array}{ll}2.1 \text { Inleiding } & 27\end{array}$

2.2 Het begrip gezondheid 27

2.3 Theorieën over sociale differentiatie 28

2.3.1 Concepten waarmee sociale differentiatie wordt beschreven 28

2.3.2 Opvattingen over maatschappelijke differentiatie 30

2.3.3 De mechanismen van maatschappelijke differentiatie 31

2.4 Sociale gelaagdheid en gezondheid 32

2.5 Leeftijd, geslacht en sociaal-economische gezondheidsverschillen 34

2.6 Modellen voor de verklaring van sociaal-economische gezondheidsverschillen 35

2.6. 1 Overwegingen 35

$\begin{array}{ll}2.6 .2 \text { Onderstellingen } & 38\end{array}$

3 MATERIAAL EN METHODEN 39

$\begin{array}{ll}3.1 & \text { Inleiding } \\ 39 & 39\end{array}$

3.2 Databestanden 39

3.3 Beperking tot hoofden van huishoudens 41

3.4 Onderlinge afstemming van de data-bestanden 42

3.5 Indicatoren 44

3.5.1 Gezondheid 44

3.5.2 Sociale differentiatie 46

3.6 Methoden 47

3.6.1 Inleiding 47

3.6.2 Metrische en niet-metrische Principale Componentenanalyse 48

3.6.3 Schaalanalyse volgens Mokken. $\quad 50$

3.6.4 Multiple Regressie Analyse 50

3.6.5 OLS Regressie 50

3.6.6 Logistische regressie $\quad 52$

3.6.7 Bewerkingen materiaal 52 
4. INDICES VOOR SOCIALE DIFFERENTIATIE: STATUS, KLASSE EN BURGERSCHAP

4.1. Een index woor sociaaleconomische differentiatie 55

4.2. Indicatoren voor klasse $\quad 60$

4.2. Woonsituatie $\quad 61$

4.2 .2 Kwaliteit van de woonomgeving 61

4.2 .3 Werksituatie $\quad 62$

4.2 .4 Bezüt 63

4.3. Indicatoren voor status $\quad 64$

4.3 .1 Geloofsovertüging en politieke voorkeur $\quad 64$

4.3.2 Vrije tijdsbesteding 65

4.3.3 Leefwilze: roken en alcoholgebruik $\quad 67$

4.4. Indicatoren woor burgerschap 68

4.4 .1 Burgerlijke staat 68

4.4.2 Lidmaatschap van en activiteiten in verenigingen 68

4.4.3 Maatschappelike activiteiten $\quad 69$

$\begin{array}{ll}4.4 .4 \text { Gebruik van voorzieningen } & 70\end{array}$

5. RESULTATEN 73

5.1. Sociaal-economische gezondheidsverschillen onder Nederlandse hootden van huishoudens

$\begin{array}{lll}\text { 5.2. Sociaal-economische gezondheidsverschillen als artefact } & 75 \\ \text { 5.3. Sociaal-economische gezondheidsverschillen als gevolg van selectie en drift } & 76\end{array}$

5.4. Verklaringsmechanismen van sociaal-economische gezondheidsverschillen 76

5.5. Relatios tussen de onderscheiden mechanismen 77

5.5.1 Klasse, status, burgerschap: complementaire of concurrerende verklaringen? 77

5.5 .2 Verklaringsmechanismen en SES-index

5.5.3 Aspecten van leefsituatie, leefwijze, sociale participatie en gezondheidsverschillen

5.6. Leeftij, gesiacht en sociaal-economische gezondheidsverschillen 82

6. CUMULATIE EN SOCIALE CONSISTENTIE VAN GEZONDHEID-

BEINVLOEDENDE FACTOREN: Effecten van kiasse, status en burgerschap op. verschillen in gezondheid

6. 1. Inleiding

6.2. Aanzetten tot het mechanisme van sociaal-economische gezondheidsverschillen 89

6.2.1 Cumulatie van effecten $\quad 90$

6.2.2 Sociale inconsistentie 91

$\begin{array}{ll}\text { 6.3. Methode } & 92\end{array}$

6.3. Het meten van cumulatie van belastende omstandigheden 93

6.4. Resultaten 96

6.4.1 Het cumulatie-model $\quad 97$

6.4.2 Het sociale inconsistentie-model 99

6.5. Discussie: Cumulatie en Consistentie 102 
7. SAMENVATTING VAN DE BELANGRIJKSTE UITKOMSTEN

7.1. Vraagstelling en concepten

7.1.1 Vraagstelling:

7.1.2 Concepten

7.2. Materiaal en methode

7.3. Samenvatting van de bevindingen

7.4. Betrouwbaarheid en geldigheid van de resultaten

8. THEORETISCHE EN PRAKTISCHE RELEVANTIE VAN DE RESULTATEN 115

8.1. Nadere specificatie van de uitkomsten woor klasse, status en burgerschap 115

8.1.1 Klasse en gezondheid $\quad 115$

8.1.2 Status en gezondheid $\quad 116$

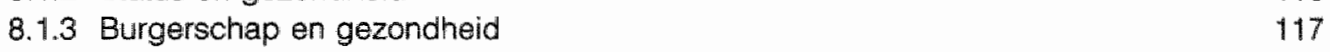

8.2 Burgerschap en gezondheid: een theoretische beschouwing 117

8.2.1 De betekenis van burgerschap $\quad 118$

8.2.2 Burgerschap en 'sense of coherence" 120

8.3. Betekenis van de resultaten voor onderzoek en beleild 123

$\begin{array}{ll}\text { 8.3.1. Conclusies voor onderzoek } & 123\end{array}$

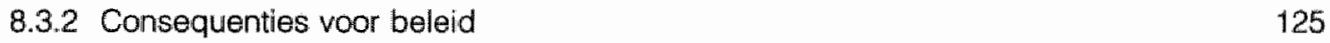

$\begin{array}{lr}8.4 & \text { Epiloog } \\ \end{array}$

$\begin{array}{lr}\text { SUMMARY } & 129\end{array}$

$\begin{array}{ll}\text { LITERATUUR } & 137\end{array}$

$\begin{array}{ll}\text { BIILAGE } & 145\end{array}$

CURRICULUM VITAE 


\section{SCHEMATA}

Schema 1 De relatie van sociale gelaagcheid met gezondheid

Sohema 23 modellen voor de verklaring van social-economische gezondheidswerschillen

Schema 3 Indicatoren wan sociale gelaagdheid en thun meting.

Schema 4. Factoren in de leefsituatie, leefstij en sociale participatie die met name verariwwoordelijk zijn voor verschillen in gezondheid

Schema 5 De relatie tussen klasse, status, burgerschap, sense of coherence, distress en gezondheid

Schema A Rubrieken van gebrukte variabelen en hun wookomen in de onderscheiden steekproeven van de Nederlandse Bevolking

Schema B De gebruikte concepten en indiceringen, en hun onderlinge relatie

\section{TABELLEN}

Tabel 1 Aantallen ondervraagde personen en hoofden van huishoudiens in de gebruikte steekproeven

Tabel If Procentuele werdelingen optimale schaling van antwoordcategorieên op vragen in de surveys naar lawaal op het werk

Tabel III Oordeel eigen gezondheid van hoofden van huishoudens in de Nederlandse bevolking 1974-1983 in procenten

Tabel IV Voeg-scores van hoofden van huishouidens uit de Nederlandse bevolking $1974-1983$ in procenten

Tabel $V$ Beroep (sociale groep) in de onderscheiden steekproeven uit de Nederlandse bevolking

Tabel VI Ondenwijsniveau van de respondenten in de onderscheiden steekproewen uit de Nederlandse bevoiking

Tabel VII Gemiddeld jaarinkomen en spreiding (mediaan en interkwartiel-range) in de onderscheiden steekproeven uit de Nederlandse bevalking

Tabel VII Optimale schaalwaarden (HOMALS) woor de kenmerken van de kwaliteit van do woning in 1983

Tabel IX Percentage hoolden van huishoudens natar de kwaliteit van de woonomgeving in de periode 1974-1983

Tabal X Optimale schaalwaarden (HOMALS) voor kenmerken wan het werk in 1983

Tabel $X 1$

Werkornstandigheden wan hoofden van hulshoudens (\%) naar bestand

Tabel $X \| l$

percentage hootden van huishouden naar het bezit van duurzame consumpliegoederen voor hel huishouden en voor de vrije tijd in de periode 19741983

Tabol XIII Mate van deelname aan culturele activiteiten (\%) in de urije tijd

Tabel XIV Mate van dgelname aan sportieve activiteiten (\%) in de vrije tijd

Tabal XV Percentage hoofden van huishoudens en hun mate van alcoholgebruik en roken in de periode 1974-1983

Tabal XVI Principale Componenten van Iidmaatschappen woor het survey 1983

Tabel XVII Principale Componenten van wrijwilligerswerk voor het survey 1983

Tabel XVIII Principale Componenten in het gebruik van voorzieningen in het survey 1983

Tabel $X I X$ Veranderingen in verklaarde variantie voor gepercipieerde en ervaren gezondheid bij invoering van verschillende mechanismen voor SEGV

Tabel XX Veranderingen in verklaarde variantie in gezondheid bij afzonderlike en gezamenlike analyse van de klasse, status en burgerschap

Tabel $X X \mid$ Relatie tussen de verschillende indicatoren voor gezondheid en de SES-index vóor en na invoering van drie mechanismen van SEGW 
Tabel XXII Samenhang (B) wan kenmerken wan klasse met het oordeel over de eigen gezondheid, de envaren gezondheid en de aanwezigheid van chronische aandoeningen (b)

Tabel XXIII Samenhang (B) van kenmerken wan status met het oordeel over de eigen gezondheid en de ervaren gezondheid

Tabel XXIV Samenhang (b) tussen kenmerken wan status met de aanwezigheid van chronische aandoeningen

Tabel XXV Samenhang (B) wan kenmerken wan burgerschap met het oordeel over de eigen gezondheid en de ervaren gezondheid

Tabel XXWI Samenhang (b) van kenmerken van burgerschap met de aanwezigheid var chronische aandoeningen

Tabel XXVII B-coefficienten van leeftijd en geslacht met drie maten van subjectieve gezondheid voor en na imvoering van kenmerken van sociale differentiatile

Tabel 1 Aantall chronisch zieke hoofden van huishoudens (\%) in de Nederlandse bevolking 1974-1983

Tabel 2 Geloof en politiek voorkeur van hoofden wan huishoudens (\%) in surveys en panel

Tabel $6 \quad$ Aantallen (\%) hoofden van huishoudens naar kenmerken van het werk voor antwoordcategorieên met een schaalwaarde kleiner dan $* 11$ of met de kleinste schaalwaarde in het survey 1983

Tabel 7 Werkomstandigheden van hoofden wan huishoudens (5) naar bestand

Tabel 8 Bezit van goedleren onder hoofden wan huishoudens (\%) naar bestand

Tabel 12 Percentage hoofden van huishoudens dat gebruik maakt van bepaalde voorzieningen

Tabel 13 Veranderingen in verklaarde variantie voor gepercipieerde en ervaren gezondheid en de aanwezigheid van chronische aandoeningen bij invoering van het cumulatiemodel

Tabel 14 Samenhang ( $\beta$ ) wan cumulatiekenmerken met gepercipieerde en ervaren gezondheld

Tabel 15 Samenhang (b) van cumulatietermen met de aanwezigheid van chronische zieikten 


\section{AFBEELDINGEN}

Afbeelding 1 SESindex naar opleiding per bestand 59

Afbeelding 2 SESindex naar inkomen per bestand 59

Afbeelding 3 SES-index maar sociale groep per bestand 60

Albeelding 4 De beschrijuing van de activiteiten in de vrije tijd van de niet en wel gehercodeerde vragen uil het survey $1977 \quad 66$

Afbeelding 5 Socialateconomische ongelijkheid in chronische ziekten in de periode 19741983

Afbelding 6 Sociaaleconomische ongelijkheid in oordeel over de eigen gezondheid in de periode 1974-1983

Afbeelding 7 Sociaal-economische ongelifkheid m.b.t. ervaren gezondheid in de periode 1974-1983

Afbeelding 8 Partivle carrelaties tussen de SES-idex en gezondheidsindicatoren 

VERSCHIJNSEL

\subsection{Inleiding}

Sinds lang is bekend dat gezondheid en ziekte in de samenleving niet gelijk zijn verdeeld. Al vór de grote pestepidemie halverwege de veertiende eeuw wordt door tijdgenoten waargenomen dat de 'zwarte dood' niet volstrekt willekeurig om zich heen grijpt, maar de armen heviger treft dan de rijken. Kroniekschrijvers uit die tijd stellen vast dat de pest "wooral de lagere soort en gewoon volk aanvalt - zelden de magnaten'. Zil schrijven dit toe aan de misere, behoeftigheid en het harde leven, die de armen vatbaarder maakten. (Tuchman 1979, Cipolla 1976). De belangrijke rol van geld bij het overleven wordt "bezongen" in het dertiende eeuwse gedicht van de 'Arcipreste de Hita' uit Spanje. Hij had waargenomen dat geld' "recht maakt wat krom is en wat krom is recht' en dat 'waar geld is veel wierook wordt gebrand" ofwel dat kerk en rijkdom innig waren verstrengeld (Juan Ruiz (1283-1350), Libro de buen Amor). De levenskansen van de rijken werden zowel hier op aarde als in het hiemamaals hoger geschat dan die van mensen zonder geld. Geld en aanzien werden dus al vroeg herkend als middelen waarmee het individu zijn levenskansen kon beïnwloeden. Hoewel tegenwoordig ook de bevalkingsconcentraties in de steden, de vaak erbarmelijke hygiënische omstandigheden en gebrekkige huisvesting, het gebrek aan riolering en schoon drinkwater mede als corzaken voor de epidemieèn worden aangewezen, hebben deze observaties nog steeds niet aan kracht ingaboet bij de verklaring van sociaal-economische gezondheidsverschillen (Sen 1992; Lundberg 1991). In veel steden werd aan het begin van de moderne tijd gepoogd pauperisme tegen te gaan door voorzieningen voor de armen te treffen. Dikwils werden deze activiteiten als ketterij veroordeeld (bijvoorbeeld in Lyon en leperen aan het begin van de vifftiende eeuw). Tot de doorbraak van de Verlichting in de $18^{\circ}$ eeuw, werden verschillen tussen rijk en arm gezien als 'natuurlijk' of 'van God gegeven'. Het bestaan van armoede sitelde de rijken in staat zich barmhartig te tonen en aalmoezen te geven (Davis 1965). Verzet tegen de ongelijke verdeling van goederen en tegen de maatschappelijke orde, werd beschouwd als verzet tegen God of in leder geval tegen de kerkelikke orde. Armoede en de opheffing ervan worden in die tijd als een individueel en niet als een collectief probleem beschouwd.

Pas de laatste twee eeuwen heeft de idee veld gewonnen dat mensen wan nature gelijk zijn en dat de 'natuurlike', 'van God gegeven' orde door de mens zelf wordt gecreeerd en dat de ongelijkheid uitkomst is van menselijke streven en handelen. Ofschoon daarmee de sociale ongelijkheid tussen mensen en bijgevolg ook de verschillen in gezondheid tussen sociale lagen in de samenlewing ten principale problematisch zijn geworden, duurt het toch tot het einde van de $19^{*}$ eeuw, voordat het politiek-filosofisch gelijkheidsideaal in de praktik van het maatschappelijk leven gestalte krijgt. Binnen de bestaande machtsverhoudingen in de samenleving regeert vooreerst nog het primaat wan de industrieel-technologische ontwikkeling.

Vooral voor de $19^{*}$ eeuw zijn de leefornstandigheden en gezondheidsproblemen van do laagste klassen goed gedocumenteerd. In Engeland worden de gevolgen van de Industriële Revolutie met de instroom van goedkope, ongeschoolde arbeiders van het platteland in overvolle steden en slecht geëquipeerde tabrieken in tall van rapporten beschreven (Chadwick, Farr, Greenhow. Guy. Simon. Smith). De stijgende mortaliteit, de epidemieen van allerlei 
infectieziekten, waaronder met name tuberculose, worden daarin toegeschreven aan de overbsvolking, slechte behuizing, gebrekkige samitaire voorzieningen in de steden, armoede. ondervoeding, harde arbeid en verschrikkelijke arbeidsomstandigheden van de "working classes: (Fosen 1973).

In Nederland komt men tot soortgelike conciusies (Verdoom 1981). Verdoom concludeert dat "chronisch onvoldoende en ondoeimatige voeding. zware en uitputtende arbeid met te korte rustperioden, slechte huiswesting, onhygienische toestanden als gevolg van overbevolking en het ontbreken van zelfs minimale sanitaire voorzieningen, door de economische situatie bepaalde slechte verzorging van kleine kinderen en in het bijzonder wan zuigelingen, ....." er de oorzaak van zijn dat 'de morbiditeit en de mortaliteit van de mindere welvaartsgroepen gedurende de gehele $19^{\circ}$ eeuw zo aanzienlijk veel hoger zijn geweest dan die van de welgestelde burgeri].".

Pas na 1880 zette zich in Noord-Europa en ook in Nederland een versnelde en blivende daling in van het sterfteciffer, gedeeltelijk tengevolge van succesvolle medische en technische maatregelen zoalis de pokkenvaccinatie en de aanleg van waterleidingen en rioleringen. Vờr die tijd vonden sociaal-geneeskundigen als Chadwick in Engeland en Coronel in Nederland nauwelijks gehoor voor hun opvatting dat de stedelijke ziektepatronen door maatschappelije factoren werden bepaald. In het fiberale denken van die tijd bestond weinig begrip voor de maatschappelijke bepaaldheid van het lot van de enkeling en paste zeker geen (overheids)ingrijpen in de samenleving. Ook de klassestructuur speelde een belangrijke rol in de terughoudendheid wan medische stand en overheden ten aanzien van het sociale vraagstuk van de armoede en haar gevolgen.

Ongetwiffeld deed zich tot in de tweede helft wan de $19^{\circ}$ eeuw de invloed gelden van de "Doctrine van het nut van de armoede", passend in het $17^{\circ}$ en $18^{\circ}$ eeuwse mercantilistische streven naar nationale rijkdom en macht: 'de zekerste rijkdom is gelegen in een grote massa van hardwerkende amen'. Zolang de toestroom van goedkope arbeidskrachten verzekerd bleef, bestond er in het sterk economisch georiënteerde liberalisme weinig geneigdheid om in de factor arbeid te invasteren, noch in de scholing. noch in de gezondheid van arbeiders (Airnlinger 1966). Armoede wordt gezien als motor voor de economie (Verdoorn 1981). Armoede zou voarkomen dat mensen niets om handen zouden hebben en hun tijd in ijdelheid zouden sliften en zou hen aanzetten tot inventiviteit en tot werken om zich in de strijd om het bestaan overeind te houden. Niemand zou immers vrijwillig tot het leger van leaglopers willen behoren. In Engeland en in Nederland leidde deze zienswijze tot het onderscheid tussen mensen die buiten hun schuld in behoeftige omstandigheden verkeerden (weduwen met kinderen; zieken en gebrekkigen: "the deserving poor' of "échte armen") en mensen die hun misere aan zichzelf hadden te danken (gokker's, drinkers, leeglopers, goddelozen).

De liberalie verklaring van de status quo als onvermijdbaar resultaat van ijzeren economische wetten' vond steun in de leer van de kerken, volgens welke de 'standen" moesten worden gezien als de door God verordonneerde maatschappelijke orde, waarin iedereen zijn plaats heeft (en ook moet houden). Tot zijn verdriet heeft ook Thorbecke, die het probleem van de toenemende welvaart en de ongelike verdeling daavan onderkende, het verbond tussen iberale bourgeoisie en kerk niet weten te doorbreken: 
nieuw een deel "eene klasse wan het wolk. Temidden eener maarschappil op gementecht der leden gebouwd. word een onowerklimbare grens tussen bewoegden an onbovoegden gestiokt." (Citaat in Verdoorn 19811 )

Dankzil de opkomende, uit een rijkgeschakeerd gedachtengoed gevoede arbeidersbeweging. waarin werklieden en arbeiders zich door veel strijd en vaak grote persoonlijke offers organiseerden en actie voerden, in samenwerking met, soms onder leiding van dissidente bourgeois intellectuelen, slaagden de progressieve krachten in de samenleving er in deze "jzeren wetten" te doorbreken. Het socialisme, in vele gedaanten (en met veel onderlinge gekrakeel) heeft daarin een belangrijke rol gespeeld en bijgedragen tot verbeteringen op het gebied van lonen, arbeidswetgeving en tot de vorming van politieke partijen, die uiteindelikk participeerden in het bestel van de parlementaire democratie (Schouten 1976).

Met de voortschrijdende industriële oniwikkeling kwamen trouwens werkgevers geandeweg tot het inzicht dat afgebeulde kinderen voor de toekomst niet de geschilktste arbeidskrachten opleveren en dat de indusitrielle bedrijvigheid evenmin gebaat is bij ondervoede arbeiders die nauwelijks in staat zijn het zware fabriekswerk te verrichten (Verdoorn 1981). Eerst in Duitsland. later ook in andere zich industrialiserende landen, ontstond dan wat kan worden genoemd de 'Doctrine van het economisch nut van de gezondheid" - de opvatting dat investeringen in de sociale zekerheid en de gezondheid van arbeiders ruimschoots worden terugverdiend door een verhoogde produktiviteit als gevolg van een verbeterde conditie van de arbeider, lager ziekteverzuim en minder bedrijfsongevallen (Rimlinger 1966; Zola 1973). De Swaan wijst or op dat ook de overlast en de bedreiging die van de armen uitging voor de openbare orde, de gezondheid en het welzijn wan de gegoede burgerij, een belangrijke rol hebben gespeeld in de totstandkoming van collectieve maatregelen door stedelijke en centrale overheden op het gebied van hygiëne, gezondheidszorg en onderwijs (de Swaan 1989).

\subsection{De sociale gelaagdheid in de tweede helft van de $20^{\text {stes }}$ eeuw}

Bekende ontwikkelingen, zoals het proces van arbeidsdeling, het toegankelijk maken van gezondheidszorg, onderwijs en welzijn voor brede lagen van de bevolking, van democratisering, rationalisering en bureaucratisering van de samenleving, de enorme groei in vooral natuurwetenschappelijke kennis, met toepassingen op het gebied van de techniek en ook de medische wetenschappen, de sterke stijging in weVaart na WO II, brengen dan in WestEuropa een samenleving teweeg. waarin weliswaar standskenmerken nog steeds geldigheid bezitten en de sociale gelaagdheid even onvermijdelikk wordt geacht als een eeuw geleden, maar de sociale ongelijkheid niet meer door 'natuurlijke' of 'door God gewilde" verschillen tussen mensen wordt gelegitimeerd. Er bestaan verschillende verklaringen voor de bestaande ongelijkheid naast elkaar, zoals de Marxistische opvatting van een unidimensionele basis van sociale ongelijkheid, het wel of niet bezitten van de produktiemiddelen (kapitaal en grondbezit) en de dominante, (neo)Weberiaanse verklaring volgens welke naast de economische basis ook andere dimensies (kennis, prestige, leefstij) de sociale gelaagdheid bepalen. lemands socialle positie (of zijn staatsburgerschap) wordt niet meer gedetermineerd door zijn milieu van her. komst. Recht van vereniging en wergadering en stemrecht gelden vanzelfsprekend voor alle leden van de samenleving en door prestatie en vooral door het volgen van onderwijs is stijging op de maatschappelijke ladder eerder norm dan toevallige uitzondering.

Met de ratificatie van de Universele Verklaring van de Rechten van de Mens gaan soclale maatregelen, die voorzien in materiële bijstand, toegang tot onderwijs en gezondheidszorg. bescherming van werknemers en toezicht op de woonomstandigheden, tot de expliciete verantwoordelijkheid van de staat behoren. Na twee wereldoorlogen en de economische crisis 
van de jaren dertig, was duidelik geworden dat een zuiver juridisch geformuleerd burgerschap niet vanzelf ook stands- en statusverschilien opheft.

Artikel 25. 1 van de Universele Verklaring wan de Rechten van de Mens luid::

Een ieder heeft recht op en lewensstandatal, die hoog genoeg is woor de gezondheid en het

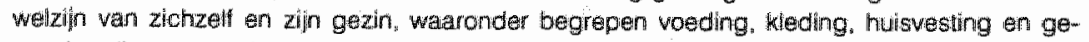
neestundige werzorging en de noodzakelfke sociale diensten, alsmede het rech op voorzieningen in gaval van werkloosheid, zlekte, inwaliditeit, overiligen van de echtgenoot, ouderdom of oen ander gemis aan bastaeinsmiddelen onstaan ten gevolge van omstandigneden, onafharketilk wan zin wil.

Deze sociale grondrectiten zijn in de Nederlandse grondwet opgenomen:

Arl. 19.1 Bevordering van voldoende werkgelegenheid is voowerp van zorg voor de overheid.

2. De wel stelt regels omtrent de rechtspositie wan hen die arbeid werrichten en hum bescherning daarbil. alsmede omtrent medezeggenschajp.

Art. 20.1 De besttanszekerheid der bevolking en spreiding van weivaart zijn voowerp van: zorg vari de overheid.

2 De wet stelt regeis omtrent de aansoraken op sociale zekerheid.

3 Nederlanders hier te lande die niet in hun levensonderhoud kunnen voorzien. heboen een bill de wet te regeten recht op bilstand van overheidswege.

Art. 21 De zorg van de overheild is gericht of de bewoonbaarheid van he? land an de bescherming an verbetexing van met leefmilieu.

Art. 22.1 De overheid trelt matregelen ter bevordering van de volksgezondheid.

2 Bevordefing van woldoende woongelegenheid is voonwerp van zorg voor de overhaid.

3 Zij schept voorwaarden voor maatschappelijke en culturele ontplooing en voor vilietijdsbesteding.

Het is de taak van de overheid om via een gedifferentieerd systeem van basis- en voorgezet onderwijs gelijke (stijgings)kansen voor haar burgers te creëren. Inkomenstegenstellingen worden ingeperkt door een progressief belastingsysteem. Voor de onderste lagen stelt de overheid zich garant voor een minimum leefbaarheid via een stelsel van sociale zekerheid, minimumloon, ouderdornspensioenen, sociale woningbouw, subsidies (huren, kinderbijslag. onderwijs, cultuur) Een stelsel van loondervingswetten en ziektekostenverzekeringen stelt alle burgers in staal gebruik te maken van een gedifferentieerd gezondheidszorgsysteem.

Met deze sociale rechten hebben de inwoners van de nationale staten binnen Europa niet alleen nominaal, maar ook substantieel het burgerschap verworven dat Thorbecke een eeuw eerder voor ogen had, althans in principe. De Engelse socioloog Marshall wijst er op dat er feitelijk, naast verschillen in stand, kllasse of status, ook verschillen in burgerschap bestaan, dat wil zeggen in de mate waarin mensen aanspraak kunnen maken op politieke en sociale rechten, deel kunnen nemen aan de samenleving en gebruik kunnen maken van de voorzieningen die de staat voor haar burgers heeft getroffen, en dat nog steeds afkomst of etniciteit, opleiding, bezit of leefwijze van invloed zijn op de mate waarin mensen hum burgerrechten kumnen uitoefenen (Marshall 1969). Het door Deleeck gesignaleerde 'Mattheus effect' "namelijk dat onder invloed van sociaal-culturele factoren een groot aantal voordelen van het sociaal overheidsbeleid verhoudingsgewijs meer naar hogere dan naar lagere sociale categorieèn gaat, maakt duidelijk dat het bestaan van sociale regelingen nog geen garantie vormt dat ze overeenkomstig de bedoeling uitwerken (Deleeck 1988).

Overigens lagen aan het inkomens- en sociale zekerheidsbeleid van de overheid van de zestiger en begin zeventiger jaren behalve saciaal-democratische principes van sociale 
rechtvaardigheid, ook inzichten uit modeme economische theorieen ten grondslag. met name de gedachte dat voor een op massaproduktie gericht produktiesysteem de koopkracht van de massa's een essentiele voorwaarde is.

Vanaf eind zeventiger jaren noodzaken een stagnerende economie en tinancieingstekorten de overheid tot steeds ingrijpender bezuinigingen op de collectieve uitgaven. In heel West-Europa doen overheden verwoede pogingen greep te krijgen op de ontwikkelingen in de gezondheidszorg en de saciale zekerheid en de kosten ervan terug te dringen. Een groot probleem daarbij is dat een belangrijk deel van de kosten het onvermijdelijke gevolg is van de effecten van een hoge levensstandaard en een sucicesvolle medische zorg, namellik de veroudering wan de bevolking. In ieder geval in Nederland spelen daarbij ook moeilijk te beinvioeden ontwikkelingen in de samenleving een rol: een tendens de ziektelast af te wentelen op de professionele zorg, een werslechterde arbeidsmarkt woor gehandicapten en een toename van de psychische belasting in het werk (SCP 1990). In toenemende mate wordt het overheidsbeleid op hett gebied van onderwijs "werkgelegenheid, inkomensontwikkeling. sociale zekerheid en gezondheidszorg gebaseerd op technische rekenmodellen, met behulp waarvan sociaall-democraten en liberalen, al dan niet gezamenlijk, zoeken naar een optimum tussen behoud wan koopkracht, werkgelegenheid en sociale zekerheid enerzijds en kosten van de factor arbeid en sociale lasten voor bedrijfsleven en financierbaarheid van de collectieve voorzieningen anderzijids. Het sociale zekerheidsstelsel is ernstig onder druk komen te staan. De (centrum-rechtse) overheid roept op tot een 'zorgzame samenleving' waarin burgers zorg hebben voor elkaar en zelf verantwoordelijkheid nemen voor ziekenzorg en gezond, preventiel gedrag, in welke visle overigens de benadrukking van ongezonde en riskante leefwijzen als belangrike oorzaken van zlekten en wan sociaal-economische gezondheidsverschillen past. In de discussies over bijstelling, omvorming of afbraak van de verzorgingsstaat blijkt het oude liberale onderscheid tussen 'echte armen' en leeglopers nog steeds opgeld te doen. Nu heten ze 'meerjarige echte minima' of "WAO'ers auder dan 50 jaar' dan wel 'fraudeurs' of 'werkonwilligenen". De bezorgd. heid in het sociaal-democratische kamp over een tweedeling van de samenleving op de grens van het minimum inkomen geeft aan dat het voor de sociaal en economisch zwakkeren in de samenleving (nog) moeilijker is geworden om hum burgerschap te realiseren. Zij moeten bovendien ervaren dat het gebruik van de sociale grondrechten, zoalis het claimen en ontvangen van een uitkering wegens werkloosheid, ziekte of gebrek, hum burgerschap aantast, omdat ze erop worden aangekeken en vaak als 'tweederangs burgers' worden beschouwd (Marshall 1969; Culprit 1992; Tumer 1993).

\subsection{Hedendaagse gezondheidsverschillen}

\subsubsection{Epidemiologisch profiel}

Ook op het gebied van gezondheid is de samenlewing ingrijpend veranderd. Kenmerkend voor het epidemiologisch profiel van dit tijdperk van de 'man-made diseases' (Omran 1979) zijn de sluipend verlopende degeneratieve ziekten (hart-en vaatziekten, kanker, ALDS), de hoge aantallen verkeers- en sportongevallen. Typerend voor deze tijd is dat veel ziekten geen latale afloop meer hebben. De mortaliteit ligt aanzienlik lager dan de morbiditeit. Verouidering van de bovolking en de groei van medische kennis en technologie dragen bij tot het historisch unieke verschijnsel van een groot en nog steeds groeiend aantal chronisch zieken en gehandicapten. In Nederland komt voor de beroepsbevalking het hedendaagse probleem van chronische ziekten als medisch en als sociaal verschijnsel pregnant tot uiting in enorme stijging van de WAO/ AAW uitkeringen. Behalve het succes en tegelijkertijd de beperkingen van de biomedische geneeskunde, die resulteren in grote aantallen weliswaar overlevende, maar niet volledig te genezen en geïvalideerde, chronische patiemten, dragen andere factoren als arbeidsmarkt- 
situatie, economische reorgariisaties in het bedrijfsleven, zlekteopvattingen bij werknemers en taakopvattingen bij de keuringsartsen bil aan andere opvattingen over chronische aandoeningen en ziekten en de mate waarin deze voor mensen een handicap vormen, dat wil zeggen met de 'sociale constructie' van de handicap (Diederiks, Joosten, Vlaskamp 199i: Nijhof 1991). Echter, gemeten aan de klassieke indicatoren mortaliteit en levensverwachting staat de gezondheidstoestand van de bevolking op een ongekend hoog peil: bij hun geboorte hebben Nederlanders gemiddeld 76.8 jaren voor de boeg. Infectieziekten zilin succesvol bestreden, longontsteking, bronchitis, griep, soms ook tuberculase komen nog wel voor, maar behoeven dankzij de grotere weerstand van de bevolking en de beschikbare medicijnen niet meer dodelijk te zijn. In Wost-Europese landen manifesteert de kwetsbaarheid van het bestaan zich niet meer in directe confrontatie met massale of vroegtijdige dood (Philipsen 1978).

Dat wil niet zeggen dat in de hedendaagse samenleving zich geen verschillen in gezondheid meer voordoen. Individuen verschillen van elkaar in gezondheid als gevolg van verschillen in genetische uitrusting. geboortetrauma, ziekte in de vroege kinderjaren, expositie aan adversieve leefomstandigheden. met name aan toxische agentia, en verschillen in eet-en drinkgewconten en riskant gedragingien, zoals roken. Deze individuele verschillen zijn evenwel miel altijd of volledig te verklaren als idiosyncratisch, toevallig of thet gevolg van biologische factoren zoals leeftijd en, tot op zekere hoogte, geslacht. Voor een deel zijn ze uiting van de ongelijke verdeling van schaarse goederen in de bevolking of het gevollg daarvan. Een laag geboortegewioht, complicaties bij de geboorte en ziekte in het eerste levensjaar, komen veel meer voor bij kinderen in de lagere sociale lagen, van bijstandsmoeders en van allochtonen dan bij kinderen in de hogere statuscategorieern, in volledige gezinnen en in de autochtone bevalking (Oakly 1994). Bepaalde riskante gedragingen zijn vaker te vinden in de lagere statusgroepen: mannen uit de lagere statusgroepen roken meer, bewegen minder, eten vetter en hebben een grotere kans met geweld in aanraking te komen dan mannen in hogere statusgroepen. Deze en dergelijke individuele gezondheidswerschillen dragen op geaggregeerd niveau bij aan systematische gezondheidsverschillen tussen lagere en hogere milieus.

\section{3 .2 Het Black Report}

Hoewel het niet erg aannemelijk is dat zich tussen eind vorige eeuw en de zeventiger, tachtiger jaren van deze eeuw geen sociaal-economische verschillen zouden hebben voorgedaan. is in die periode noch door de overheid noch door de wetenschap aandacht besteed aan dit probleem, waarschijnijk in de overtuiging dat door welvaartsstiging, inkomensnivellering. sociale zekerheidsstelsel en een algemeen toegankelijk gezondheidszorgsysteem sociaaleconomische gezondheidsverschillen tot hat verleden behoorden. Pas de afgelopen viftien, twintig jaren zijn beleidmakers en wetenschappers zich (weer) bezig gaan houden met gezondheidsverschilen tussen de sociale klassen. In Engeland was bezorgdheid over groter wordende verschillen in montaliteit tussen de sociale klassen en vooral ook het achterblijven blj andere (rijke) landen in de daling van sterfteciffers, voor de Britse minister van Sociale Zaken in 1977 aanleiding tot de instelling van een speciale werkgroep onder voorzitterschap van Sir Douglas Black met de opdracht sociaal-economische gezondheidsverschillen te onderzoeken. Op grond van literatuurstudies werd in het rapport van de werkgroep (het zgn. Black Report) geconcludeerd, dat er weliswaar een algemene verbetering van de mortaliteit en morbiditeit van de Engelse bevolking was waar te nemen, maar dat er toch in een rijk land als Engeland niet te accepteren sociale verschillen in gezondheid en in beschikbaarheid en gebruik van gezondheidszorgvoorzieningen bestonden, die in de periode 1950-1970 waren toegenomen (Townsend, Davidson 1982). In een latere studie, waarin ook gegevens uit de jaren zeventig werden verwerkt, bleken de sociaal-economische verschillen in gezondheid in dat decennium nog pregnanter naar voren te komen (M. Whitehead 1988). 
Misschien juist doordat de Britse regering beide rapporten in eerste instantie wilde negeren, kregen deze rapporten, onder druk van de medische stand en de publieke pers nogal wat publiciteit en konden ze een belangrijke rol spelen in de internationaal hemieuwde belangstel ling voor het probleem van de sociaal-economische gezondheidsverschillen.

De persistentic wan gezondheidsverschillen tussen en binnen landen was in 1984 aanleiding voor de Europese lidstaten van de Wereldgezondheidsorganisatie woor de instelling wan het programma 'Health for All in the Year 2000. Een van de doelstellingen van dit progranma is de vermindering van gezondheidsverschillen tussen sociale groeperingen binnen de nationale staten.

\subsubsection{Sociaal-economische gezondheidsverschillen in Nederland}

Ook in Nederland werd gaandeweg duidelijk dat gezondheid (nog steeds) ongelijk is verdeeld over sociale status categorieen. Uit Amsterdams buurtonderzoek kon worden geconcludeerd dai in de perioden 1972-1976 en 1977-1983 sociaal-economisch laag geklasseerde buurten op indicatoren als sterte, ziekenhuisopnamen, arbeidsongeschiktheid slechter scoorden dan de rijkere buurten (van der Maas, Habbema, van den Bos e.a. 1987). Op het niveau van gemeenten bleek de combinatie van deprivatie vam recreatieve en gezondheidszorgvoorzieningen, bevolkingsdichtheid, woningnood en atnemende industrialisatie (gegevens Votkstelling 1960) samen te gaan met relatief hoge ciffers voor doodgeboorte, infectieziekten als dysenterie, roodvonk , salmonellosen, hepatitis infectiosa en afgekeurden voor militaire dienstplicht wegens S5 (Drop 1979). Al in de zeventiger jaren, kort na de inwerkingtreding van de Wet op de Arbeidsgeschiktheid, was bekend dat de 'instroom' van arbeidsongeschikten vooral bestond ult ouderen met een relatief geringe scholing en werkzaam in structureel-economisch zwalkke bedrijfstakken. Met name de jongere arbeidsongeschikt-verklaarden kenmerkten zich door een laag opleidings- en beroepsniveau (Grosveld 1981).

De participatie aan het WHO-programma droeg er toe bij dat ook in Nederland de sociaal. economische gezondheidsverschillen weer op de politieke agenda werd geplaatst.

In 1987 werd door de Nederlandse staatssecretaris voor Volksgezondheid een Programmacommissie Sociaal-Economische Gezondheidsverschillen ingesteld om het wetenschappelijk onderzoek naar deze verschillen in gang te zetten en te stimuleren. Een eerste inventarisatie van onderzaek over de periode 1982-1987 (Mackenbach, Stronks 1988), leidde tot de conclusle dat in Nederland hoger op de maatschappelijke ladder geplaatsten een betere gezondheid genieten dan de lager geplaatsten. Het ziet er naar wit dat de gezondheidsindicatoren geboortegewicht, lichaamsiengte van volwassenen, gezondheidsklachten, (meeste) langdurige aandoeningen, lichamelike beperkingen, arbeidsongeschiktheid en sterte van volwassenen ongunstiger zijn bij een lagere sociaal-economische status. In een specifieke studie werd aandacht besteed aan chronische aandoeningen "hiervoor al gesignaleerd als een van de belangrijkste gezondheidsproblemen van deze tijd. Voor elk van de drie gehanteerde indicatoren voor sociaat-economische status (beroep, opleiding en inkomen) werd een negatieve samenhang met de prevalentie van chronische aandoeningen gerapporteerd, zij het dat zich afwijkingen en uitzonderingen voordeden. Zo meldden bijvoorbeeld ouderen met eeri hogere beroepsopleiding meer chronische aandoeningen dan op grond van een lineair verband zou mogen worden verwacht, rapporteerden wrouwen ongeacht beroep, opleiding, inkomen of leeftijd meer chronische aandoeningen dan mannen en kwamen sommige aandoeningen (bivoorbeeld schildklierafwikingen, prostaatklachten, nierziekten) meer voor in de hogere dan in de lagere sociaal-economische klassen. Voor de drie sociaal-economische indicatoren gezamenlijk waren de (negatieve) verschillen tussen de hogeren en de lagere klassen het sterkst voor chronische bronchitis en andere longziekten, ziekten van het zenuwstelsel beroerte en suikerziekte (van den Bos, Lenoir 1991). 
Hoewel het er near uitziet dat evenals in Engeland, de sociaal-economische gezondheidsverschillen in Nederland in de zevertiger en tachtiger jaren zijn toegenomen (Mackenbach 1994), zijn in Wederland, evenals in de Scandinavische landen, de sociaal-economische gezondheidsverschillen relatief gering, zeker waar het gaat om verschillen in mortaliteit (Kunst, Mackenbach 1993; Fox 1989). De laatste bevinding stemt overeen met de resultaten van een analyse van Wilkinson, waarin werd aangetoond dat in landen, waar door inkomensnivellering en sociale zekerheid de inkomensverschillen naar verhouding gering zijn (Nederland, Zweden, Noorwegen), de mortaliteit lager is en dat (rijke) landen waar de inkomensverdeling erg scheef is, worden gekenmerkt door een hoge mortaliteit (Verenigd Koninkrijk, Frankrijk, voormalig WestDuitsland) (Wilkinson 1990). In Nederland leven mensen met een hogere opleiding gemiddeld 4.5 jaar langer dan laag opgeleiden. De verschillen in gezonde lewensverwachting zijn groter. Op 65-jarige leeftijd hebben mannen met een hogere opleiding nog 10.6 gezonde levensjaren voor zich en 5.8 jaren met een minder goede gezondheid; mamnen met alleen lager onderwijs wachten nog 7.2 gezonde levensjaren wachten en 6.1 jaar met gezondheidsproblemen (Boshuizen, van de Water, Perenboom 1994). De verschillen in gezonde levensverwachting van Engelse mannen is ongeveer even groot, maar voor blanke manmen in North Carolina in de VS en in Nieuw Zeeland zijn de verschillen geringler. Ook verschillen in subjectieve gezondheid zijh in Nederland ten opzichte van deze beide landen gering, maar toch groter dan in Zweden en het Verenigd Koninkrijk (CBS/EUR 1992). Voorzover het deze gezondheidsindicator aangaat, behoont in de internationale vergelijking Nederland qua omvang van de sociaal-economische gezondheidsverschillen tot de middenmoot.

\subsubsection{Verklaringen voor sociaal-economische gezondheidsverschillen}

Klaarblijkelijk is een geavanceerde, woor iedereen toegankelijke gezondheidszorg van hoge kwaliteit niet voldoende om gezondheidsverschillen tussen de hogere en lagere milieus te voorkomen. Het ligt dus niet erg voor de hand te verwachten dat verdergaande investeringen in de curatieve zorg veel zullen bijdragen aan de opheffing van de socialal-economische gezondheidsverschillen.

De onderstelling dat de verschillen in gezondheid tussen de sociale lagen zijn te verklaren wit selectieprocessen, wia welke alleen gezonden worden toegelaten tot functies met een hoog maatschappelijk prestige, of uit drift naar lager gewaardeerde posities of zelfs uit de beroepenthierarchie van ziekgeworden werknemers, biedt evenmin veel aanknopingspunten voor de oplossing van de bestaande gezondheidsverschillen. Otschoon lichaamslengte lijkt te werken als een selectiecriterium voor goede banen en voor het werven wan een rijke echtgenoot (IIlsley 1990; Willkinson 1986), zijn uit onderzoek geen aanwijzingen naar voren gekomen dat selectie of 'drift' een belangrijke rol zouden spelen in het woorkomen van sociaal-economische gezondheidsverschillen. Deze conclusie sternt overeen met bevindingen van sociologisch mobiliteitsonderzoek. Weliswaar blijkt gezondheid van invloed te zijn op de toegang tot het onderwils (een belangrijke factor in de latere positietoewijzing), (Illsley 1990; van der Lucht 1993), maar ne de initiele positietoewijzing bil de entree op de arbeidsmarkt (van overwegend gezonde, jonge mensen) vinden er in de verdere loopbaan geen grote veranderingen meer plaats: men stijgt (of daalt) binnen de bandbreedte van de "eigen" sociale laag. Daarbij dient te worden aangetekend dat in Nederland het sociale zekerheidsstelsel zoals dat de achierliggende decennia heeft gefunctioneerd, voor veel mensen im ieder geval wat hun inkomen betreft een daling naar een lager milieu tengevolge van ziekte of ongeval heeft voorkomen. Kan daaruit enerzijds worden geconcludeerd dat het sociale zekerheidssteisel een belangrijk instrument kan zijn in de preventie van (nog ernstiger) verschillen in gezondheid tussen de sociale lagen, anderzijds behoeven juist daarom de bestaande sociaal-economische gezondheidsverschillen nadere verklaring. 
In de literatuur worden twee, soms expliciet als concurrerend gepresenteerde visies op sociaal economische gezondheidsverschillen aangetroffen: die waarin deze worden verklaard uit verschillen tussen de sociale lagen in (materiele) leefomstandigheden en die waarin de gezondheidsverschillen worden toegeschreven aan verschillen tussen de lagen in leefwijzen en riskante gewoonten. Hoewel door onderzoek voor beide verklaringen empirische evidentie wordt aangedragen, is het onderzoek naar de relatieve bijdrage vam beide theorieen aan de verklaring van sociaal-economische gezondheidsverschillen schaars. Zoals hiervoor in wogelviucht geschetst, hebben beide verklaringen hun wortels in de geschiedenis van liberale en socialistische of sociaal-democratische politieke denkbeelden en praktijken; ze zijn daardoor eerder ideologisch dan wetenschappelijk bepaald.

De nadruk op leefwijzen als verklaring en 'health promotion' als oplossing voor de gezondheidsverschillen tussen de hogere en lagere milieus past in de individualistische liberale traditie, waarin mensen worden geacht zelf verantwoordelijk te zijn voor eigen lot en leven en de overheid alleen de taak heeft de randvoorwaarden te scheppen waarbinnen de burgers hun verantwoordelikkeil kunnen realiseren (onderwijs, voorlichting, gezondheidszorg. De verklaring, waarin het probleem van sociaal-economische gezondheidsverschillen wordt geindividualiseerd door het te herleiden tot (de keuze van) leefwijzen en gewoonten wan individuen, is niet alleen favoriet bij de medische professie met zijn sterk individualiserende benadering van gezondheidsklachten, maar ook bil politici en beleidmakers die er weinig voor voelen de bestaande orde ingrijpend te veranderen en bovendien kampen met financieringsproblemen. De uitspraak van de Engelse onderstaatssecretaris voor Gezondheid an Sociale Zekerheid Sir George Young naar aanleiding van het "Black Report' is in dit werband illustratief:

\footnotetext{
I see progress being made by encouraging health education, personal responsibility for health, and encouraging voluntary organizations to help in the personal social services and helping to complement the NHS. That is the right way fonward, given the difficult economic circumstances in which we find ourselwes, rather than committing ourselves to the rather expensive solutions outu ined by the Black Peport, which we are not absolutely convinced would deliver the goods". (Townsend, Davidson 1982).
}

In de collectivistische zienswijze, zoals bijvoorbeeld verwoord door de Amerikaanse socioloog Navarro, wooronderstelt de concentratie op leefwijze als oorzaak van ziekte, zonder rekening te houden met de omgeving die deze leefwijzen bepaalt, een illusoire onathankelijkheid en vrijheid van het individu. Volgens Navarro is sprake van 'blaming the victim', waardoor de structurele en collectieve problemen van een samenleving tot probiemen van de individuele burgers worden gemaakt (Navarro 1976).

Blane constateert in zijn bespreking van verschillende verklaringen van de sociaal-economische gezondheidsverschillen dat, ondanks een formidabele hoeveelheid bewijs voor een relatie ussen riskante gedragingen als roken, vet eten, alcoholgebruik, te weinig beweging e.d. en doodsoorzaken als coronaire hartziekten, longlkanker en chironische bronchitis, de "leetwijze werklaring" blootstaat aan forse kritiek (Blane 1985). Sommige critici accepteren weliswaar de etiologische betekenis van deze gedragsfactoren, maar ontkennen dat deze een autonome rol zouden spelen. Zij zien hel gedrag als geconditioneerd door de sociale en materiële context waarin het plaatsvindt. In hun optiek moeten gedragsfactoren worden gezien als intermediërende variabelen tussen sociale structuur en ziekte. Ze zijn verbonden met de sociliale structuur door factoren als toegang tot onderwijs, kennis, gedeelde normen en waarden. Door gedragingen van hun sociale context te abstraheren, kunnen ook de functies van 'pathologisch' gedrag worden miskend. Zo kan het vele roken door de 'working class' worden begrepen uit de "obvious match' tussen de farmacologische eigenschappen van de nicotine ('allays fatigue and 
maintains perfornance during monotonous lasks'. 'serves as a means of maintaining a constant mood in situations of stress') en de arbeidsomstandigheden van veel arbeiders.

Andere critici stellen de etiologische betekenis van de "riskante" gedragingen ter discussie. Zij zien deze gedragingen als indicatoren voor andere werschijnselen, die direct werband houden met de sociale structuur en de eigenilike etiologische factoren zijn. De sigarettenroker bijvoorbeeld zou ook well eens blootgesteld kunnen zijn aan luchtwervilling thuis en aan stof en dampen op het werk ('Does smoking kill workers or working kill smokers?" Sterling 1978). Wolgens Blane zelf ligt er voor de "leewvijze benadering" een belangrijk historisch precedent in de negentiende eewwse pogingen de slechte gezondheid van arbeiders en hun gezinnen te begripen uit vuil, viezigheid en gebrek aan hygiëne. Hoewel deze factoren inderdaad een rol speelden in bijvoorbeeld typhus en daminfecties, verwezen ze naar andere, belangrijker factoren, zoals onvoldoende voeding en chronische uitputting van de wrouwen tengevolge van overwerk en vele zwangerschappen. Naar zijn mening wordt het belang van culturele en gedragsmatige verklaringen van sociaal-economische gezondheidsverschillen overschat en wordt er in onderzoek en in beleid te weinig aandacht besteed aan materiële verklaringen. volgens welke klasse-verschillen in gezondheid worden gezien als het resultaat van structureel bepaalde verschillen in leven, wonen en werken van deze klassen (Black Report). Behalve arbeidsomstandigheden, variërend wan stukwerk, monotonie, gebrek aan controle over lawaai, temperatuunwisselingen, toxische stoffen, worden in de literatulu luchtvervuiling van de woonwijk, vochtige en tochtige huizen, geldzorgen, als factoren genoemd waarvan de etiologische werking is aangetoond dan wel nader onderzoek behoeft: 'Factors which may' be important have been largely ignored despite the fact that they are widespread, obviously class related and plausible hypotheses exist suggesting how they produce disease' (Blane 1985). Het concept sociale kasse verwijst naar een combinatie van voordelen en deprivaties, die zijn verbonden aan een bepaalde positie in de sociale hiërarchie. Er zou daarom meer onclerzoek moeten worden gedaan naar de cumulatieve en interactieve effecten van verschillende oorzakelike lactoren, materiele (bijvoorbeeld werk- èn woonomstandigheden) en culturele of gedragsmatige factoren (Townsend. Davidson 1982; Blane 1985). Bovendien zou aandacht moeten worden besteed aan de verklaring van een omslag in de sociaal-economische gradient, zoals zich bijwoorbeeld heeft voorgedaan voor hart-en vaatziekten, die na de tweede werelcoorlog veranderden van managersziekte tot volksziekte (Kunst, Mackenbach 1990) en van gezondheidsproblemen met een omgekeerde sociale gradient, zoals bijvoorbeeld allergieen en kanker van de alvleesklier. Door het geringe aandeel in de totale mortaliteit en morbiditeit van de laatst genoemde categorie ziekten ten opzichte wan de ware "volksziekten" hart-en vaataandoeningen, longkarker en CARA die de sterkste sociale gradiënt vertonen (Illisley, Carr-Hill 1987), word weliswaar de algemene trend van sociaal-economische gezondheidsverschillen niet verstoord, maar hun voorkomen geeft aan dat algemene verklaringen, zoals hiervoor besproken, niet toereikend zilin om ziekte-specifieke verschillen in morbiditeit en mortaliteit van bepaalde bevolkingscategorieën te verklaren. Gezien de clifermatige verhoudingen in de prevalenties var de werschillende diagnosecategorieën kunnen deze algemene verklaringen echter wel belangrijke aanwijzingen geven omtrent die mogelijke oorzaken van sociale verschillen in gezondheid. 


\subsection{Het onderhavige onderzoek}

De Nederlandse inventarisatie van het onderzok naar socialweconomische gezandheidswerschillen toonde vergellikbare lacunes aan, niet alleen wat betreft de gezondheidsaspecten (er is te weinig aandacht woor specifieke ziekteproblemen. waarvoor de sociale gradient niet steeds dezelfde blijkt te zijn), maa ook ten aanzien van verklarende variabelen die niet of nauwelijks in onderzoek worden betrokken (0.a. materiële voorzieningen in de privésfeer). Evenzo zijin er nog nauwelijks studies verricht, waarin de verschillende factoren die als werklaring voor het ontstaan van de gezondheidsverschilen tussen socialle status categorieën worden genoemd, in hun onderlinge samenhang zijn onderzocht en hun relatieve bijdragen zijn bepaald (Mackenbach 1994: Stronks, Mackenbach 1988). De oorzaken van de sociaal-economische gezondheidsverschillen in Nederland zijn nog verre van duidelijk (Gunning-Schepers 1991). Het in 1988 ingestelde Programma Saciaal-Economische Gezondhaids verschillen was er op gericht in deze lacumes te voorzien. Inmiddels zijn in het kader van dit programma tal van studies verricht, waarvan de resultaten zijn gepubliceerd in de reeks "Sociaal-Economische Gezondheidsverschillen Onderzocht". Het onderzoek dat thier wordt verslagen, is mede mogellijk gemaakt door ean subsidie uit dit programma.

Met dit onderzoek, waarin de mechanismen van de relatie tussen sociaal-economische status en gezondheid centraal staan, wordt beoogd een bijdrage te leveren aan de verklaring van de ongelijke verdeling van gezondheid over sociale status-categorieën. Het is verricht vanuit de opvatting dat systematische verschillen in gezondheid tussen bepaalde bevolkingscategoriesn geen natuurlijk gegeven zijn, maar in hoge mate worden bepaald door sociale en culturele factoren die samenthangen met de ongelijke verdeling van schaarse goederen in de bevolking en die, zoals in het verleden herhaaldelijk is gebleken, beinwloedbaar zijn door politieke besiluitvorming. In dit opzicht is de maatschappelijke relevantie van deze studie gelegen in de vraag welke door politiek en beleid beïnwloedbare factoren verantwoordelijk zijn woor de gezondheid van mensen in de verschillende lagen van de bevolking. In concreto gaat het hier om de keuze van variabelen als werk- en woonomstandigheden, die anders dan bijwoorbeeld de demografische opbouw van de samenleving. zich lenen voor beleidsmaatregelen door de overheid zonder dat imbreuk behoeft te worden gemaakt op de persoonlike levenssfeer (vergelijk bijwoorbeeld wetgeving op het gebied van arbeidsomstandigheden en voorschriften voor woningbouw met regelingen op het gebied van partnerkeuze, kindertal of preventief genetisch onderzoek).

Het wetenschappelifk belang van het onderzoek bestaat in de eerste plats uit het streven een bijdrage te leveren aan de invulling van éen wan de nationaal en internationaal gesignaleerde lacunes in het onderzoek naar sociaal-economische gezondheidsverschillen: de analyse vam zowel de afzonderlijke bijdragen wan materiele factoren (woon-en werkomstandigheden) en culturele factoren (leefwijzen) aan de verklaring van deze verschillen, als de cumulatieve en interactieve effecten van deze beide categorieën oorzakelijke factoren op de sociale gelaagd. heid van gezondheid.

De theoretische relevantie van de studie ligt in de poging de onderzochte mechanismen van de samenhang tussen sociaal-economische status en gezondheid te funderen in sociolagische theorieèn over sociale stratificatie en te relateren aan de begrippen klasse en status en in de introductie en uitwerking van het begrip burgerschap als een lot op heden niet eerder met sociaal-economische gezondheidswerschillen in verband gebracht aspect van sociale differentiatie.

De analyses ziljn uitgevoerd op gegevens uit de Leefsituatieonderzoeken 1974, 1977, 1980 en 1983 van het Centraal Bureau voor de Statistiek en de Panelstudie naar de gezondheid van de Nederlandse bevolking, in 1981 en 1983 uitgevoerd door de vakgroep Medische Sociologie van de Rijksuniversiteit Limburg. Het gebruik van deze databestanden heeft ondermeer als 
consequentie dat het onderzoek betrekking heeft op algemene verklaringen van verschillen in subjectieve gezondheid en zelf-gerapporteerde chronisch zieken.

In hel voorgaande is beschreven dat de relatie tussen sociaal-economische status en gezondheid weliswaar nauwelijks meer wordt betwiffeld, maar dat tegelijkertijd de verklaning van deze verschillen tamelijk gecompliceerd is. Het onderzoek naar deze gezondheidsverschillen en met name het onderzoek naar hel samenstel van factoren, dat deze verschillen zouden kunnen verklaren, is evenredig ingewikkeld. Bij de formulering van de vraagstelling, de keuze van opzet en variabelen en bij de interpretatie van de uitkomsten, moet met een aantal zaken rekening worden gehouden:

a. Ofschoon reeel, zijn dankzij het (nog steeds) hoge welvaartsniveau, de sociale zekerheid, het hoge gemiddelde opleidingspeil, de goede kwaliteit van, voor iedereen bereikbare, gezondheidszorg, in Nederland verschillen in gezondheid, ook die naar sociaal-economische status, niet erg groot. Dat impliceert dat van de verschillende corzakelijke factoren ook geen sterke verbanden mel gezondheidsindicatoren kunnen worden verwacht.

b. Sociaal-economische gezondheidsverschilen wariëren naar leeftijd en geslacht, alsook naar soort gezondheidsklachten. Dit laatste kan leiden tot onderschatting van causale effecten bij gebruik van algemene, a-specifieke gezondheidsindicatoren, zoals gemeenlijk onderzocht in surveyonderzoek.

c. Het belang van de onderscheiden dimensies van sociaal-economische status (en hun indicatoren beroep, opleiding, inkomen) is onderwerp van discussie. In onderzoek zijn voor opleiding en inkomen verschillende effecten op gezondheid geconstateerd: een slerk effect van verschillen in opleiding op de sterfte van wrouwen, maar van inkomensverschillen op sterfte van mannen (Williams 1990). Er zal dus niet alleen aandacht moeten worden besteed aan de relatieve bijdrage van de onderscheiden dimensies van sociaal-economische status, maar ook aan de specificiteit van hun relaties met gezondheidsindicatoren.

d. De afstand in de causale keten tussen sociaal-economische status en gezondheid is groot. De effecten wan sociaal-economische status verlopen via dichter bij de gezondheidsuitkomst gelegen omstandigheden en gedragingen. De relatie tussen (indicatoren wan) sociaal-economische status en gezondheid is daarom minder consistent dan die tussen de dichterbij gelegen oorzaken (roken, voeding, milieuvervuiling e.d.) en gezondheid (van Berkel-van Schailk, Tax 1990), Er dient derhalve te worden gecontroleerd op consistentie en stabiliteit van onderzoeksuitkomsten, bijwoorbeeld in verschillende steekproeven en over verschillende perioden.

e. Sociaal-economische status houdt verband met zeer viteenlopende levensomstandigheden. die alle gezondheid kunnen beinvloeden. De specificiteit van de relatie tussen sociaaleconomische status en gezondheidsproblemen is daardoor gering. Het is daarom zaak de betekenis van de onderscheiden dimensies van sociaal-economische status voor de verschillende bereiken van het leven en hun relatie met gezondheidsrisico's te specificeren.

f. In de relatie tussen sociaal-economische status en gezondheid kunnen verschillende factoren tegelikertijd werkzaam zijn. waardoor afzonderlijke effecten van onderzachte factoren kunnen worden over- of onderschat. Zo kunnen gelijktijdige effecten van luchtverontreiniging of stoffige werkomstandigheden en roken op luchtwegaandoeningen leiden tot overschatting van het effect van roken (Sterling 1978, Blane 1985). Met beroep en inkomen samenhangende factoren kunnen leiden tot gezondheidsklachten en ziekte, welke op hun beurt sociale stijging verhinderen of zells leiden tot lager geklasseerd werk en inkomensdaling. De werking van selectie- en/of driftmechanismen kan leiden tot overschatting van de sterkte van de causale effecten van beroep of inkomen (Williams 1990). 
In deze studie worden op basis van de huidige theorieen over sociale differentie, de afzonder. lijke dimensies van sociaal-economische status geconceptualiseerd en geindiceerd. De gevolgen van de onderscheiden dimensies voor woon en werkomstandigheden, leefstijl van mensen worden, voorzover het beschikbare materiaal dat toestaat, geoperationaliseerd en zowel afzonderlijk als gezamenlijk in verband gebracht met indicatoren voor chronische ziekten en subjectieve gezondheid.

In hoofdstuk twee worden de begrippen, waarmee sociale differentiatie is omschreven, nader onderzocht op hun betekenis voor het verklaren van sociaal-economische gezondheidsverschilien. Het word afgesloten met de formulering van de onderstellingen van het onderzoek. In hoofdstuk drie worden opzet en methoden van het empirisch onderzoek beschreven, alsook het datamateriaal waarop de analyses worden ütgevoerd. Hoofdstuk vier is gewijd aan de operationalisatie van de gebruikte begrippen. De hoofdstukken viff en zes bevatten de resultaten van het onderzoek. In hoofdstuk vijf worden de afzonderlijke bijdragen van klasse, status en burgerschap aan de verklaring van de sociaal-economische variatie in gezondheid gepre. senteerd, in hoofdstuk zes wordt nader onderzocht of en in hoeverre cumulatie dan wel inconsistentie van de indices van klasse, status en burgerschap bijdragen aan de verklaring van de gezondheidsverschillen. In het zevende en laatste hoofdstuk worden de resultaten samengevat en besproken en wordt nagegaan welke aanbevelingen voor beleid, dat is gericht op vermindering van sociaal-economische gezondheidsverschillen, aan de uitkomsten van het onderzoek kunnen worden ontleend. Aan het boek is nog een appendix met tabellen van de gebruikte variabelen en indexen toegevoegd. 



\section{$2.1 \quad$ Inleiding}

De vraagstelling van deze studie, verklaringen te winden voor het bestaan van verschillen in gezondheid tussen de sociaal-economische lagen, is in eerste en laatste instantie niet een vraag naar gezondheid, maar een vraag naar aard en effecten van sociale gelaagdheid. Daarbij wordt gezondheid niet opgevat als uitsluitend de aan-of afwezigheid van bepaalden objectiveerbare lichamelijke of geestelijke aandoeningen ("diseases'), maar als een maatschappelijk goed, zoals macht, aanzien, bezit, opleiding of sociale relaties (coninecties), waarover mensen in meer of mindere mate beschikken. Er kain alleen dan van sociaal-economische gezondheidswerschillen worden gesproken indien kan worden aangetoond dat maatschappelijke omstandigheden verantwoordelijk zijn voor de ongelijke verdeling over de sociale lagen van de risico's op objectieve of subjectieve gezondheidsstoornissen. Uit het hoge ziekteverzuim onder bouwwakkers en het frequent voorkomen van gewrichtsklachten in deze beroepsgroep in vergelijking tot beroepsgroepen met meer sociaal prestige mag bijvoorbeeld niet worden afgeleid dat in de bouw vooral ongezonde mensen werken. Er kan eventueel wel worden geconcludeerd dat de arbeidsomstandigheden in de bouw te wensen overlaten en er is sprake van sociaal-economische gezondheidsverschillen indien de slechtere arbeidsomstandigheden uitdrukking zijn van de ongelijke verdeling van macht, aanzien en gewin in de samenleving. Het vraagstuk van de sociaal-economische gezondheidsverschillen is daarmee een verdelingsprobleem. Niet het vórkomen van ziekten in verschillende sociale categorieën is het probleem, maar de ongelijke spreilding van gezondheid over door sociaal-economische verschillen gedefinieerde lagen van de bevolking; niet de ongelijke verdeling van risicofactoren voor een bepaalde aandoening, maar de verklaring voor hun angelijke verdeling over de sociale lagen is de kern van de vraagstelling. Om deze vraagstelling te onderzoeken dienen niet de ziekten en hun risicofactoren als zodanig te worden bestudeerd, maar de aard van de maatschappelijke gelaagdheid die verantwoordelijk is voor de ongelijke verdeling ervan.

Gezondheid wordt in deze vraagstelling dus beschouwd als een sociaal kenmerk, ongeacht de opvatting van gezondheid als de afwezigheid van objectieve, aantoonbare aandoeningen den wel als subjectief ervaren geestelijke en lichamelijk welzijn. De werklaring van sociaal-economische gezondheidsverschillen vereist derhalve een nadere bepaling van de begrippen gezondheid en sociale differentiatie en van het verband dat tussen beide bestaat.

\subsection{Het begrip gezondheid}

Kan ongezondheid worden opgevat als de aanwezigheid van objectief aantoonbare aandoeningen, de afwezigheid van ziekte is niet toereikend om gezondheid volledig te definieren. Men kan zich zilek woelen ('iliness'), zonder dat daarvoor een afwijking is aan te wijzen; evenzo kan men zich als zieke gedragen ('sickness"), ongeacht of men zich ziek voelt of een aandoening heeft (Freidson 1970). Ook het omgekeerde is mogelijk. Van der Horst (1988) laat zien. dat velen die zich ziek voelen en een aandoening hebben, zich als gezonden gedragen: ongeacht hun objectieve conditie en subjectieve ervaring blijen deze mensen betaald werk verrichten. 
In studies naar opvatingen over gezondheid blikt dat in Nederland (Joosten 1988), het Verenigd Koninkrijk (Currer, Stacey 1986; Williams 1983). Frankrijk (d'Houtaud, Field 1984, 1986; Herzlich 1973) en de Verenigde Staten (Baumann 1961) gezondheid drie onafhankelik van elkaar variërende aspecten kent, te weten gezondheid als de mogelikheid alles te kunnen doen (activiteit of "functional fitness'), als het beschikken over een sterk gestel (kracht) en als een waardering van een toestand (evaluatie). Al deze aspecten van gezondheid verwijzen naar subjectieve ervaringen: (onjgemak bij het uitvoeren van activiteiten, oardeel over de kracht van het eigen gestel in vergelijking met anderen en gevoelens van lichamelijk (onwwelbevinden. Deze gevoelens komen onafhankelijk van elkaar voor: men kan zich honds beroerd voelen en zich toch gezond achten, omdat men meent over een gezond gestel te beschikken; men kan in zijn activiteiten beperkt zijn, maar zich gezond voelen omdat men optimistisch en evenwichtig is. Deze condities kunnen gepaard gaan met objectief aantoonbare aandoeningen (koorts, aanwezigheid van chronische aandoeningen), maar zijn daarwan niet afhankelifk. Deze verschillende facetten van gezondheid kunnen zowel binnen als tussen mensen variëren.

Deze opvattingen en bevindingen impliceren de conclusie dat geen van de opvattingen van gezondheid of ongezondheid en de daarbij behorende indicatoren een wolledig beeld van de gezondheidstoestand van een populatie zal opleveren, ook (kostbare) objectieve medische scireeningsmethoden niet, zelfs niet in het geval van een hoge sensitiviteit en specificiteit van de gebruikte diagnostische tests. De medische ziekte- (of gezondheids)definitie zegt immers niets over de subjectief ervaren kwaliteit van de gezondheid. McDowell en Newell benadrukken als een belangrijk voordeel van subjectieve gezondheidsmetingen dat deze niet alleen verwijzen naar objectief aanwezige aandoeningen (in welk opzicht "subjectieve measures are, of course, little different from the data collected for centuries by physians when taking a medical history'), maar zil geven ook inzjcht in andere aspecten van het ziek-zijn of van het genieten van een goede gezondheid. Als andere voordelen var subjectieve gezondheidsmetingen noemen zil nog dat deze metingen niet beperkt behoeven te blijen tot relatief kleine selecties van patienten die hebben besloten met hun klachten naar de dokter te gaan, maar betaalbaar kunnen worden afgenomen bij grote steekproeven uit de algemene populatie en dat ze, anders dan de anamnese van de arts, zijn gevalideerd en gestandaardiseerd en statistisch kunnen worden bewerkt (McDowell, Newell 1987).

Bij de keuze wan het datamateriaal voor deze studie heeft de overweging dat op geen enkele andere financierbare wijze gegevens over de algemene gezondheidstoestand wan de Nederlandse bevolking zouden kunnen worden verkreglen, die in werband konden worden gebracht met een breed spectrum aan gezondheidsbevarderende of wdreigende factoren, zeker een belangrijke rol gespeeld. Daarnaast bestaat evenwel de overtuiging dat met de beschikbare (en gevalideerde) subjectieve gezondheidsmetingen de opvaltingen van de mensen zelf over de kwaliteit van hun gezondheid het dichtst worden benaderd. Bovendien bliken subjectieve gezondheidservaringen nauw samen te hangen met meer te objectiveren aspecten van gezondheid zoals de morbidi- en mortaliteit op lange termijn (Kaplan, Camacho 1983; Kaplan. Kotier 1985; Kaplan e.a. 1989), met doktersbezoek (van der Zee 1982; Visser 1983; van Sonsbeek 1990) en met de aanwezigheid van chronische condities (Visser 1983: van Sonsbeek 1990; van der Zee 1982), zodat niet veel wordt afgeweken van hetgeen in de medische wereld onder gezondheid en ziekte wordt verstaan.

\subsection{Theorieèn over sociale differentiatie}

\subsubsection{Concepten waarmee sociale differentiatie wordt beschreven}

Het verschijnsel dat tussen mensen verschillen bestaan in aanzien en macht en in de beschikking over economische en sociale hulpbronnen, vormt de kern van alle sociologische beschou- 
wingen over sociale gelaagdheid. De begrippen waarmee dit verschijnsel wordt beschreven, te weten stand, status of klasse, impliceren een keuze voor een bepaalde zienswijze op deze differentiatie. De onderscheiden concepten weerspiegelen verschillende opvattingen over de oorzaken en legitimering van de sociale stratificatie.

Het begrip stand impliceert de legitimatie van sociale ongelikheid door deze toe te schrijven aan 'natuurlijke" bij geboorte gegeven verschillen waardoor in een van God gewilde orde ieder zijn plaats en functie heeft. Kenmerkend voor de relatief gesloten standenmaatschappij is dat standen niet alleen de toegang tot schaarse middelen (macht, aanzien, gewin) bepalen, maar ook de interacties tussen mensen (binnen en tussen standen), evenals de normen en waarden waarop die zljn gebaseerd. Afstamming etmische achtergrond en geslacht bepalen iemands positie in de standenmaatschappij (Giddens 1989).

Het begrip sociale klasse, door Marx theoretisch uitgewerkt in de context van de schrijnende gevolgen van de Industriële Revolutie, legt de corzaak van de sociale stratificatie bij de ongelijke toegang tot schaarse goederen ten gevolge van verschillen in bezit van economische macht (Martin 1987).

De differentiatie naar maatschappelijk prestige en beroep vormt de kein van het begrip sociale status. Het is geworteld in de structureel-functionalistische benadering van de sociale gelaagdheid, waarbij de ongelijke verdeling van schaarse goederen wordt toegeschreven aan de gevolgen van arbeidsdeling en de daaruit voontwoeiende sociale en culturele differentiatie tussen sociale categorieèn (Luhmann 1985a).

In deze structureel-functionalistische benadering wordt de arbeidsdeling gekenmerkt door een 'objectieve' en een 'subjectieve' structuur. In de objectieve structuur worden de verschillende beroepsgroepen gewaardeerd naar hum bijdrage aan of hun functie voor de maatschappij (latente functie) (Merton 1968). De subjectieve structuur geeft de beloning (inkomen, prestige) weer woor het vervullen van de objectieve functie en de moeite (opleiding), die mensen daarvoor hebben moeten doen. In deze visie bestaan sociale lagen uit groeperingen, die min of meer gelijk gewaardeerde functies hebben in de arbeidsstructuur; sociale status representeert de positie van een individu in die lagenstructuur (Tumer 1988; Luhmann 1985a).

Ondanks de ver doorgevoerde arbeidsdeling kan niet ieder op basis wan zijn of haar beroep worden geplaatst in de objectieve of subjectieve structuur. Werklozen, arbeidsongeschilkten, moeders van jonge kinderen en gepensioneerden komen niet in de beroepenstratificatie voor. Niettemin maken ze allen deel uit van de samenleving en hebben zij er een plaats in. Van oudsher ontvangen kinderen die plaats door hun ouders. Dezen geven het kind een naam en via hun beider families een identiteit en een plaats in sociaal netwerk. De zorgplicht ten opzichte van kinderen, alsook voor zieken, gebrekkigen en ouden van dagen, wordt in de morele code van de samenleving gespecificeerd door de afstamming, die vaak "maar niet per se biologisch is bepaald (adoptiekinderen worden bijvoorbeeld juridisch gelifkgesteld aan natuurlijke kinderen). Omdat in de praktijk deze zorgplicht niet altijd werd vervuld, bijvoorbeeld omdat er geen tamilieleden meer in leven waren, zijn or al sinds de middeleeuwen door de kerken en de (stedelike) overheden woorzieningen voor zorgbehoeftigen getroften. Toewijzing van deze voorzieningen was afhankelijk van particularistische overwegingen.

Zoals in het vorig hoofdstuk werd beschreven, betekende de doorbraak van de gelijkheidsidee van de Verlichting en de opkomst van de nationale staten met hun bureaucratisch apparaat dat gaandeweg plichten en rechten, waaronder die op voorzieningen voor hulp en bijstand, geformaliseerd en vastgelegd in universele, dat wil zeggen voor alle burgers op gelijke wijze geldende, regels. Burgerschap wijst op het verschijnsel dat in de moderne staat mensen, los van hun plaats in de beroepenstructuur, aan hun lidmaatschap van de samenteving bepaalde rechten kunnen ontlenen. Via dat burgerschap kumnen mensen, ongeacht hun afstamming of 
arbeidsstatus, hun positte in de samenteving verbeteren door zich met anderen te associëren (Turner 1988).

Marshall (1967) beschrift de ontwikkeling naar buirgerschap in Engeland vanaf de eltide eeuw als het proces waarin individuele burgers op steeds meer terreinen autonomie verwerven: vrijheild wan godsdienst, van spreken, van drukpers, recht op rechtspraak, onvervreemdbaar bezit en op het afsluiten van contracten. De koninkijke gerechtshoven, die het plaatselike (gewoonte) recht steeds meer verdrongen, waren bil de uniformering van deze regels en hun implemerntatie een belangrifk instrument: Zoals geschetst heeft in de negentiende eeuw de arbeidende klasse door vakbondsstrijd en via coalities met liberalen het politiek burgerschap bevochten (stemrecht en het recht tot vertegenwoordiging). Het duurde tot zo'n kwart eeuw na de Tweede Wereldoorlog voordat, door de opbouw van de verzorgingsstaat op basis van de geciteerde mensenrechten, het sociaal burgerschap werd verwezenlijkt. De verbreding van de toegang tot het onderwijs en de sociale verzekeringen zijn de belangrijkste instrumenten voor de realisatie van het sociaal burgerschap: de mogelikheid voor ieder om volledig deel te nemen aan het sociale en culturele leven (Marshall 1969). Burgerschap is nauw verbonden met sociale orde en sociale ordening (Tumer 1993): het definieert sociale lagen, ongeacht materiële weilstand en leefstifl (Marshall 1993).

\subsubsection{Opvattingen over maatschappelike differentiatie}

De begrippen stand, klasse, sociale status en burgerschap verklaren de sociale differentiatie op verschillende wijze. Is in de standenmaatschappij de bestaande ongelijkheid tussen mensen een "natuurlijk" of "van God gegeven" verschijnsel, met de opkomst van de burgerij en de val van het Ancien Régime wordt deze ongelijkheid in de begrippen klasse en status geproblematiseerd (Luhmann 1985b). De vraag waarom de ene mens wel macht en aanzien verwerft en de andere niet, ligt sindsdien ten grondslag aan de politieke belangstelling voor het verschijnsel sociale ongelikkheid (Verhoogt 1983). In de West-Europese samenlevingen is vanaf de Tweede Wereldoorlog vooral door sociaal-democratische partijen het onderwijs gezien als middel tot sociale stijging. Door scholing zouden mensen, gegeven hun intellectuele mogelijkheden, in ieder geval aan de start gelijke kansen hebben. Omdat niet ieder zijn kansen daarna volledig benut, bliven burgers zich naar inkomen, opleiding en socilaal prestige onderscheiden. Deze differentiatie betreft zowel verschillen in het prestige dat men zich tijdens zilin leven weet te verwerven als verschillen in economische macht en in burgerschap. Op deze wijze kumnen in een samenleving, die de gelijkheid van mensen vooropstelt, personen toch worden gedifferentieerd: naar hun politieke invloed of geloofwaardigheid (gezag), naar hun economische macht (door anderscheid te maken tussen mensen die sturende functies hebben en uitwoerenden), naar mensen die hun claims op de samenleving te gelde moeten maken (bijstandsmoeders, uitkeringsgerechtigden) dan wel deze claims als sociaal kapitaal met zich meedragen zonder er (vooralsnog) een beroep op te behoeven doen (Turner 1988).

Lange tijd waren opleiding, inkomen en beroep de belangrijkste, vrije stabiele individuele kenmerken op basis waarvan verschillen in sociale status, tot uiting komend in deelname aan sport en cultur, in leefstijl en levensovertuiging, in tijdsbesteding en in maatschappelijke participatie, adequaat konden worden beschreven. Door de ver doorgevoerde arbeidsdeling in de huidige maatschappij is de relatie tussen opleiding, beroep en inkomen evenwel geërodeerd en hebben kenmerken van het beroep, zoals arbeidssector en bron van inkomen aan belang gewonnen voor het beschrijven en verklaren van verschillen in sociaal, cultureel en maatschappelijk functioneren (Berting 1983). Bovendien hebben volks-en werknemersverzekeringen de relatie tussen inkomen en beroep losser gemaakt en heeft de betere toegankelijkheid van het onderwijs een groot aantal relatief hoog geschoolden opgeleverd. Hoewel opleiding nog steeds een belangrijke voorwaarde is voor het vervullen van een groot aantal beroe. 
pen, concurreert het leger goed geschoolden mell lager geschoolden om dezelfde (schaarse) banen. waardoor in bepaalde sectoren van de arbeidsmarkt de relatie lussen opleiding en beroep minder sterk is dan op een nog niet verzadigde markt.

Burgerlike staat en lidmaatschap van verenigingen zoals wakbond, politieke partij of kerkgenootschap, zijn, als indicatoren woor de mate waarin men zijn rechten van vrije associatie kan ultoefenen, aspecten van burgerschap (Tumer 1988; King. Waidron 1989). Eohter, economische onzekerheid bemoeilijkt het aangaan van vaste relaties an als financiele middelen ontbreken bestaat de neiging zich uit het maatschappelijk leven terug te trekken. Door dergelijke ontwikkelingen is het mogelijk mensen te onderscheiden naar de mate waarin ze deeinemen aan en deel uitmaken van de samenleving. Verschillen in burgerschap impliceren niet alleen verschillen ten opzichte van andere leden van de samenleving (burgerrechten), maar ook verschillen in ideeên en gedachten over de manier waarop de samenleving in elkaar zit en over wat in het leven belangrijk is (waardenpatronen). In dat opzicht is het begrip nauw verwant aan het begrip status (Hill 1990).

De mate van burgerschap varieert bijwoorbeeld naar etniciteit: allochtonen hebbein in Nederland weliswaar recht op uitkeringen krachtens de volksverzekeringen, maar zij bezitten geen stemrecht en op de huizen- en arbeidsmarkt is hun positie zeer zwak. Ook voor ouderen en voor mensen die hun inkomen verwerven krachtens een van de loondervingswetten of volksverzekeringen geldt, dat hun positie op de arbeidsmarkt zwak is en dat met de duur van de werktoosheid of arbeidsongeschiktheid hun contacten met anderen en hun verbondentheid met de samenleving afnemen (Merens-Aledstra 1982; Sprenger, Tazelaar 1987; van der Horst 1988; van der Horst, Halfens, Philipsen, Joosten 1987).

\subsubsection{De mechanismen van maatschappelijke differentiatie}

Voor de vraagstelling van het hier gerapporteerde onderzoek zijn de onderscheiden begrippen van belang, omdat ze verwijzen naar verschillende eigenschappen van de sociaal-economische gelaagdheid die elk een eigen invloed op gezondheid kunnen hebben. Zo verwijst stand naar het verschijnsel dat er verschillen bestaan in de wijze waarop mensen zijn toegerust om zich in de samenleving staande te houden (geslacht, leeftijd, etniciteit, handicap) welke onder andere tot uiting komen in verschillen in kleding en gedrag (spraak, huwelijksvoorkeur). Status verwijst naar verschillen in normen en waarden. Deze komen tot uiting in verschillen in leefstijl (rokem, drinken, vrijetijdsbesteding), houdingen en meringen (partijpolitieke voorkeur) en denkbeelden (gelootsovertuiging; waardenoriëntatie). Zowel stand als status wijzen op verschillen in maatschappelijk prestige op basis waarvan men in meer of mindere mate in staat is zijn eigen sociale identiteit te handhaven. Bij stand is dit prestige toegeschreven, bij status moet het prestige zelf worden verworwen. Klasse impliceert werschillen in zeggingsmacht over het eigen leven en verschillen in macht om anderen in hun gedragsalternatieven te beperken. Deze verschillen komen onder andere tot uiting in verschillen in financiële armslag, in bezit, in woon-en werksituatie. Burgerschap ten slotte, houdi in dat mensen zowel verschillen in het beroep dat ze op de samenleving kunnen doen (gebruik van voorzieningen), als in de mate waarin ze daarin zijn geintegreerd (burgerlijke staat, lidmaatschap van verenigingen, het doen van viliwiligerswerk) (Turner 1990, 1988; Giddens 1989).

De onderscheiden begrippen verwijzen naar het verschijnsel dal in de gelaagdheid van onze samenleving de politieke (status), economische (klasse) en sociale dimensie (burgerschap) tot op zekere hoogte onafhankelijk van elkaar kunnen variëren, hetgeen in de standenmaatschappij net het geval was.

De begrippen stand, status, klasse en burgerschap geven de verschillende mechanismen aan waardoor de sociale gelaagdheid van de samenleving tot stand kormit. Daarbij blijken oplleiding. 
beroep en inkomen, alsook bron van inkomen belangrijke individuele kenmerken, die bij elke beschriving van deze differentiatie een rol spelen. Vanwege deze gemeenschappelijke basis is het onmogelijk status, klasse en burgerschap onathankelijk van elkaar te operationaliseren. Deze begrippen kunnen echter wel worden geïdiceerd aan de hand van hun gevolgen, te weten leefstijl voor status, leefsituatie voor Klasse en maatschappelike participatie voor burgerschap. De kenmerken, die deze drie theoretische begrippen gemeenschappelijk hebben, te weten opleiding, inkomen, beroep en bron van het inkomen, kunnen dienen als grove index van de maatschappelijke gelaagdheid (SES), waarmee de overlap tussen deze begrippen zichtbaar kan worden gemaakt.

\subsection{Sociale gelaagdheid en gezondheid}

Het hierboven uitgewerkte onderscheid in sociale gelaagdheid naar status, klasse en burgerschap is hier slechts interessant voor zover de onderscheiden mechanismen verwijzen naar verschillende verklaringsmogelijkheden woor verschillen in gezond heid ussen de sociale lagen. Hoewel over elk van deze begrippen veel meer is geschreven, halen we hier slechts de essentie van deze begrippen naar voren (Turner 1988; Bendix, Lipset 1966; Barber 1957).

Verschillen in sociale status zijn met name gebaseerd op verschillen in opleiding en in de mogelijkheid om anderen voor zich te winnen. Kennis van de samenleving maakt deze beter beheersbaar. Mensen die hun situatie en omgeving denken te beheersen vertonen minder 'distress', hetgeen een risico is voor ongezondheid. Bovendien ziln mensen met een hoge opleiding beter op de hoogte van gezondheidisbevorderende of schadende gedragingen. Hoewel dit nog niet wil zeggen dat zij dit inzicht ook altijd in hun gedrag verdisconteren, kunnen ze well schadelijke gevolgen van hun gedrag eerder onderkennen en eventueel tegengaan. Hierbij kan worden gedacht aan de keuze voor woedsel en genotmiddelen, aan de wijze van ontspanning en aan vrijetijdsbesteding. Roken en het drinken van alcoholische dranken zijn vanuit dit gezichtspunt kenmerken van leefstijl en daarmee van status. In deze visie geeft status aan dat roken en drinken niet gelijk over de bevolking zijn verdeeld. Dat deze gedragingen de gezondheid negatief kunnen beïnloeden, maakt onder andere de relatie tussen status en gezondheid begrijpelijk. Van confounding is in dit geval geen sprake. Het roken staat immers niet los van iemands sociale status, het maakt er deel van uit. Bovendien is de relatie tussen roken en drinken enerzijds en gezondheid anderzijds op individueel niveau niet erg direct. Niet alleen krigt niet elke roker een (long)ziekte en moeten de rokers die een longziekte krijgen daar meestal lang voor roken, maar ook zijn de meeste in leven zijnde rokers niet ziek, net zo min overigens als de regelmatige gebruikers van alcohol. Bovendien is de kans groot dat mensen met bepaalde chronische aandoeningen (bijvoorbeeld hart- en vaten; respiratoir e.d.) als ze ziek zijn geworden stoppen met roken en drinken en blijven anderzijds mensen roken en alcohol drinken zolang ze hun gezondheid als goed ervaren. Sociale status impliceert daarom de mate van waarschijnlijkheid waarin mensen door hun gedrag hun eigen gezondheid positief of negatief beinvloeden (Blaxter 1990).

De socilale klassen verschillen in de mate waarin zij toegang geven tot schaarse middelen: adequate huisvesting. gunstige arbeidswoonwaarden, een schoon leefmilieu en maatschappelijke zekerheild. Leden van de onderscheiden sociale klassen staan daardoor in meer of mindere mate bloot aan kou, vocht en tocht in hun woning, aan toxische stoffen, lawaaj- en stankoverlast in de leef-en werkarngeving, aan adversieve levenservaringen en, gezien de maatschappelijke (on)zekerheid, aan 'distress'. Sociale klasse geeft derhalve de kans aan dat iemand wordt blootgesteld aan deze factoren zonder dat hij zich er aan kan onttrekken of zich er tegen 
Schema 1 De relatie van sociale gelaagdheid met gezondheid

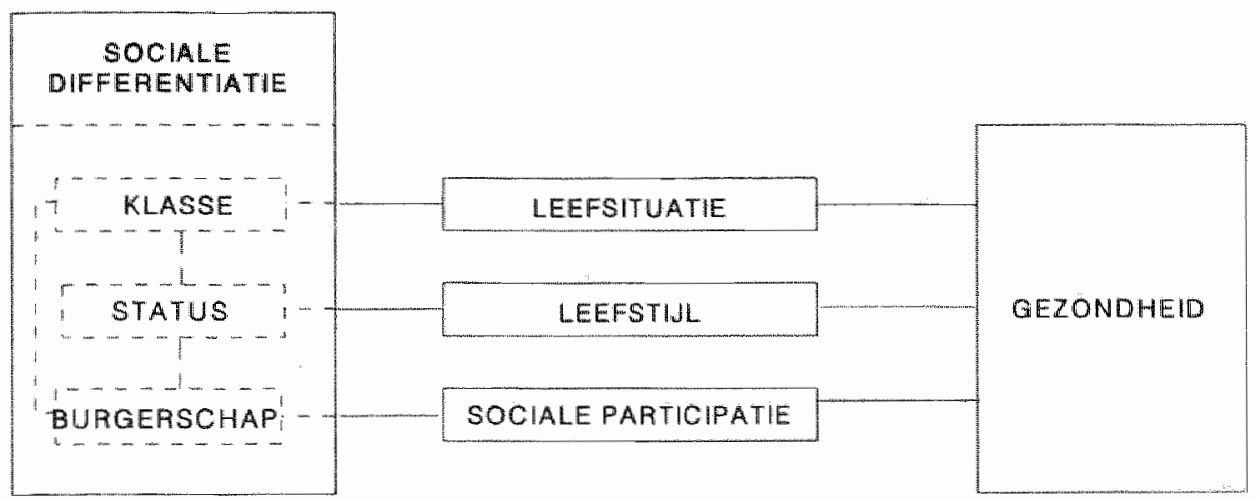

kan verweren (Blane 1991; Townsend, Davidson 1983).

Verschillem in burgerschap zijn gebaseerd op de ongelijke bescherming die de samenteving biedt. Mensen die in staat zijn hun burgerlijke rechten te doen gelden, een partner of kinderen hebben, lid zijn van verenigingen, zich omringd of ondersteund weten door familie en vrienden, kunnen niet alleen hun leven beter beheersen waardoor ze minder kans hebben op stress" Volgens de buffer-theorie lopen ze ook minder kans op stress omdat hun sociale omgeving hen beschermt tegen situaties die onzekerheid en stress zouden kunnen oproepen (Berkman. Syme 1979; Dohrenwend, Dohrenwend 1981).

Zo hebben mannen en vrouwen, die gehuwd zijn of samenwonen doorgaans een betere gezondheid dan mensen die gescheiden zijn of verweduwd (Verbrugge 1985; Chenu 1988). Ook nimmer gehuwden hebben doorgaans een goede gezondheid "hoewel dit meer voor vrouwen dan voor mannen geldt (Verbrugge 1985); vrienden en kennissen hebben een sanogeen effect (Kaplan, Salonen, Cohen e.a. 1988; Seeman, Kaplan, Knudsen e.a. 1987). De gezondheid van mensen zonder werk is, woor zover het om gepensioneerden en WAO-ers gaat, per definitie slechter dan die van de werkende bevolking. Maar ook de gezondheid van langdurig werklozen likkt slechter dan die van werkendem; het is nog onduidelijk in hoeverre de gezondheid van mensen die pas kort zonder werk zijn afwijkt van die van de werkende bevolking. Wel geldt dat voor mensen zonder werk de contacten met anderen afnemen, hetgeen indirect de gezondheid negatief kan beilnvloeden (wan der Horst 1988; Verkley 1988). De gezondheid van etnische minderheden, in hel gastland marginale groeperingen, wijkt negatief at van die van de autochtone bevolking (Leeflang. Spruit 1991; Marmot 1986). Geschat wordt dal een kwart tot eenderde van de dak- en thuislozen een psychische aandoening heeft en velen zijn verstandelijk gehandicapt, verslaafd, of hebben een chronische aandoening. Doorgaans hebben deze mensen meer dan éen van de hier genoemde kenmerken. Burgerschap lijkt daamee naast status en klasse een verklaring te kunnen geven voor sociaal-economische gezondheidsverschillen. Schema 1 geeft van deze relaties een overzicht. 


\subsection{Leeftijd, geslacht en sociaal-economische gezondheidsverschillen}

De verschillende begrippen, waamee hier de sociale differentiatie is beschreven, duiden zowel op ongelijke blootsteling aan adversieve levensomstandigheden, ais op verschillen in de manier waarop met gezondheidsschadende effecten van deze adversieve levensomstandigheden wordt omgegaan. De arvalyses, die in deze studie worden beschreven, beogen niet nieuwe inzichten te leveren in de mechanismen die bij individuen ziekten veroorzaken. Ze zijn er op gericht nieuwe informatie te gever over de verdeling van gezondheidbedreigende factoren over de sociale lagen en met name over de mate waarin deze factoren eikaar versterken of juist tegerwerken.

Echter, prealabel aan de analyse van deze verklaringen van sociaal-economische gezondheidswerschillen, is de vraag of die gezondheidswerschillen niet zijn te herieiden tot andere factoren, zoals verschillen in gezondheid op basis van leeftijd en gestacht. Door ziekte kan men in lagere sociale lagen terecht komen (drift) of in een lagere posities "gevangen" blijen (selectie) (Spruit 1988). Bovendien zijn sommige hogere sociale posities slechts te bereiken door ouderen met een goede gezondheid (Whitehead 1988).

Wat betreft de relatie leeftijd, SES en gezondheid geldt voor de huidige generatie ouderen, dat. zij vaak een lagere opleiding en een geringer inkomen hebben dan jongeren, terwij doorgaans ook hun gezondheid slechter is dan die van jongeren. Naar de mate waarin deze relaties gelden, zouden de sociaal-economische gezondheidsverschillen geheel of gedeeltelijk als artefact moeten worden beschouwd (Macintyre 1986).

Ook geslacht zou een dergelijke rol kunnen spelen in sociaal-economische gezondheidsverschillen. Vrouwen hebben in Nederland een gering aandeel in de arbeidsmarkt, ze zijn gemiddeld lager opgeleid dan mannen, vervullen veelal lager gewaardeerde functies, waarvoor ze vaak minder worden betaald dan mannen. Tegelijkertijd bestaan er in een aantal opzichten verschillen in gezondheid tussen mannen en vrouwen. Hoewel biologische verschillen tussen mannen en vrouwen een rol spelen (denk bijwoorbeeld aan de bescherming die het oestrogeen vrouwen tot de menopauze biedt tegen hartinfarct en aan het vaker voorkomen van osteoporose bij oudere vrouwen vanwege juist het dalen van de oestrogeenspiegel) vormen ze toch niet de belangrijkste reden voor deze gezondheidswerschillen (Waldron 1983a, 1983b). Belangrijker is het verschil in subjectieve gezondheid tussen mannen en vrouwen. Vrouwen ervaren over het algemeen meer lichamelijke klachten dan mannen (Joosten, Drop 1988; Mechanic 1980) en tonen zich doorgaans ook lets bezorgder of pessimistischer over hun gezondheid (Verbrugge 1990). In de literatuur zijn niet zozeer deze gezondheidsverschillen, alswel hun werklaring onderwerp van discussie (Verbrugge 1990). Algemeen wordt aangenomen dat, als er verschillen bestaan en deze dus niet op een artefact berusten, de verkiaring daarvoor zowel biologisch als sociaal van aard is. Echter, saciale omstandigheden kunnen zowel in het voordeel van het ene als van het andere gesiacht werken "zoals ook de fysieke uitrusting nu eens de gezondheid van mannen dan weer die van wrouwen beschermt. Verbrugge (1990) heeft aangetoond dat, indien wordt gecontroleerd voor een aantal kenmerken uit de leefsituatie, niet alleen de levensduur (bij uitstek een indicator voor objectieve gezondheid), maar ook de subjectieve gezondheid van mannen achterblijt bij die van wrouwen. De aard van deze sexegebonden gezondheidsverschillen kan echter variëren met leeftijd en sociale omstandigheden. Blaxter (1990) laat zien dat vrouwen uit huishoudens met een gering inkomen in hun wruchtbare jaren meer gezondheidsproblemen ervaren dan mannen, maar dat mannen van 45 jaar en ouder uit huishoudens met een gering inkomen meer gezondheidsproblemer hebben dan vrouwen uit deze leeftijds- en inkomensklasse. Voor een aantal aspecten van gezondheid ('ilhess", "fitness', 'disability') beschrijft zij hoe deze tussen mannen en vrouwen niet alleen naai" 
sociale laag. maar ook per leeftijdscategorie verschillen (pag. 64-65). Ze laat ook zlen dat al naar gelang de leeftijd, risicofactoren als roken, drinken, voeding, beweging verschillende effecten hebben op de gezondheid van mannen en vrouwen (pag. 190 e.v.). Klatbilijkelijk verwizen leeftijd en geslacht niet alleen naar biologische veroudering on lichamelijke verschillen, maar ook naar sociale verschillen. Leettijd en geslacht zijn basale, door de "natuur" gegeven kenmerken waarop voor een deel de sociaal-economische differentiatie berust (bij. lagere of achterblijende scholing, belemmerde toegang tot het arbeidsproces van ouderen en/of vrouwen). Door de interactie tussen de biologische effecten (veroudering, biologische uitrusting) en de sociale consequenties (leeftijds- en geslachtsrollen) is in elk onderzoek naar sociaal-economische gezondheidsverschillen de betekenis van leeftijds- en geslachtseffecten dubbelzinnig.

Bovendien is de sociale betekenis van leeftijd en geslacht niet eenduidig te interpreteren. Sommigen beschouwen geslacht als klasse kenmerk vanwege de verschillen tussen mannen en vrouwen in economische macht. Anderen wijzen erop dat leeftijd en geslacht specifieke status-rollen zijn, die als het ware alle andere sociale rollen kleuren: zij specificeren specifieke leefstijlen. Daarnaast zijn veel burgerrechten gedefinieerd op basis van leeftijd en geslacht. Beide begrippen vormen daarmee kennelijk een belangrijke pijler van de sociale differentiatie. Aangezien de begrippen leeftijd en geslacht in alle drie concepties van sociale differentiatie een even belangrijke, maar verschillende, rol spelen, zij de kern vormen van alle sociale differentiaties en gebaseerd zijn op 'natuurlijke', 'aangeboren' kenmerken, passen zil het nog het beste in hel authentieke begrip voor sociale differentiatie, namelijk stand.

Door hier leeftijd en geslacht als indicator voor kenmerken van stand op te vatten "worden de meervoudige betekenissen verzoend; standskenmerken berusten immers per definitie op toegeschreven eigenschappen. In deze optiek is ook leeftijd geen continue, maar een discrete variabele met verschillende, sociaal-cultureel of sociaal-economisch bepaalde breukpunten (bijv. leerplichtige leeftijd, huwelijksleeftijd, pensioengerechtigde leeftijd).

\subsection{Modellen voor de verklaring van sociaal-economische gezondheidsverschillen}

\subsubsection{Overwegingen}

Op grond van het voorgaande ligt het woor de hand in de analyses eerst na te gaan inhoeverre de verschillen in (subjectieve) gezondheid tussen de sociaal-economische strata zijn toe te schrijven aan verschillen in leeftijd en geslacht, d.w.z. als een artefact zijn te beschouwen. (Schema 2). Wordt deze onderstelling verworpen, dan zal vervolgens worden gepoogd na le gaan of de sociaal-economische gezondheidsverschillen het gevolg zijn van de eerdere gezondheidstoestand, d.w.z. te herleiden zijn tot drift of selectieprocessen. In dit transversale onderzoek zullen de bijdragen van deze processen als 'chronische ziekte' in het model worden vertegenwoordigd. Volgens de selectie en drift hypothesen zou immers de aanwezigheid van chronische aandoeningen sociale status, klasse en burgerschap negatief beinvloeden.

Tenslotte zullen in thet model de relaties tussen de gevolgen van sociale status, klasse en burgerschap worden gespecificeerd. De cruciale vraag in dit onderzoek is of de mechanismen van status, klasse en burgerschap slechts verschillende uitingsvormen zijn van 'distress' dan wel een eigen, onafhankelijk effect op gezondheid hebben. In het eerste geval veronderstellen sociale status, klasse en burgerschap elkaar en voegen ze niets toe aan de effecten van de kenmerken die ze gemeenschappelijk hebben (opleiding inkomen en beroep). in het tweede geval leveren ze een significante eigen bijdrage aan de verklaring van de gezondheidsverschillen. Omdat tot op heden niet meer bekend is dan dat leefstijl (sociale status), leefsituatie (klasse) en sociale participatie (burgerschap) gezondheid beinvloeden, is het moeilijk over de relatieve bijdrage van elk van de drie mechanismen aan (on)gezondheid specifieke hypothew 
sen te genereren. Hooguit kan worden gesteld, dat ek een noodzakelijke maar zeker geen voldoende voorwaarde vormt woor het bestaan van sociaal-economische gezondheidsverschitlen. De sociale gelaagdheid impliceert immers een ongelije verdeling zowel wan schaarse goederen als van gezondheidsbevorderende en schadende gedragingen. De vraag is dan nief of leefstifl of leefsituatie gezondheid negatief beinvloedt, maar onder welke condities do leefsituatie en leefstijl een bijdrage leveren aan de verklaring van verschillen in gezondheid. Leetstijl en leefsituatie zullen elk slechts een deel van de verschillen in gezondheid verklaren. (Macintyre 1986).

Het is denkbaar dat de ondierscheiden mechanismen ekkaar versterken of juist opheffen "of dat bepaalde aspecten van de leetstill, de leefsituatie en van de sociale participatie interacteren in hun effecten op gezondheid. Everzo is niet uit te sluiten dat de genoemde verklaringen voor verschillen in gezondheid tussen de sociaal-economische lagen, elk geldig zijn voor andere aspecten van (on)gezondheid. Op dit terrein heeft tot op heden weinig formele theorievorming plaatsgevonden, ook ontbreekt empirisch onderzoek. Als al aandacht wordt besteed aan interactie tussen verschillende oorzakelijke factoren, dan gaat het om effecten van roken en drinken of van roken en eetgewoonten. Uit de bestaande theorieën zijn geen preciezere uitspraken omtrent aard of richting van dergelijke interacties aft te leiden.

In het geval blootstelling aan adversieve levensomstandigheden het verklarend mechanisme vormit "Ijkt het aannemelijk cen cumulatie van effecten te mogen werwachten bij blootstelling aan verschillende gezondheidschadende factoren tegelijkertij. Een dergelijk cumulatief effect onderstelt echter dat deze factoren niet ondering afhankelijk zijn of vrijwel altijd gezamenlijk voorkomen: dat wil zeggen dat wordt ondersteld dat mensen die veel roken niet vrijwel altijd ook zwaar drinken (een loze aanname (Kozlowski. Ferrence 1990)) of dat slechte werkomstandigheden vrijwel nooit samengaan met inadequate woonomstandigheden (hetgeen in strijd is met onderstellingen uit theorieèn over sociale klasse).

In dit verband moet ook aandacht worden besteed aan een sociologische traditie, waarin inconsistenties binnen en tussen status, klasse en burgerschap verantwoordelijk worden gesteld voor spanningen tussen de verschillende levensgebieden van het individu, die gezondheid negatief zouden beilnvloeden en zouden leiden tot lichamelijke klachten en psychische problemen. Statusinconsistentie, het uiteenlopen in een persoon van klasse-kenmerken en leefstijl of van leefstij en burgerschap of van alie drie, wordt verondersteld via het mechanisme van chronische stress het ontstaam van cardio-vasculaire aandoeningen te beilnvloeden (Dressler 1988;1993, Siegrist 1991). Dit verband is tot op heden echter niet overtuigend aangetoond. Discrepanties tussen leefstijen en klasse zouden ook een uiting kunnen zijn vam een gebrekkig vermogen on de omgeving te beheersen. Siegrist (o.c.) laat zien dat dit gebrek aan controle en hoge werkdruk elkaar versterken bij het ontstaan van cardiomasculaire aandoeningen.

Gezien de gebrekkige kennis op dit terrein wordt het verklaringsmodel voor sociaal-economische gezondheidsverschillen niet direct uitgebreid met mogelijke interacties. Eerst wordt nagegaan of en in hoeverre de gespecificeerde mechanismen elkaar onderling beïnloeden en daarna zal binnen de onderscheiden mechanismen worden nagegaan of cumulatie van adversieve levensomstandigheden of sociale inconsistenties in klasse "status en burgerschapskenmerken een extra bijdrage leveren aan de verklaring van verschillen tussen mensen in gezondheid. Vanwege de onduidelijkheid over de precieze relaties tussen klasse, status en burgerschap enerzijds en van deze mechanismen met gezondheid anderzijds wordt in dit onderzoek geen poging gedaan tussen deze mechanismen interactie-effecten te specificeren.

Tenslotte is het nodig nog iets nader in te gaan op de wijze waarop leettijd en geslacht de relaties tussen status, klasse en burgerschap enerzijds en gezondheid anderzijds beiinvloeden. 
Schema 23 modellen voor de verklaring van sociaal-economische gezondheidsversohillen

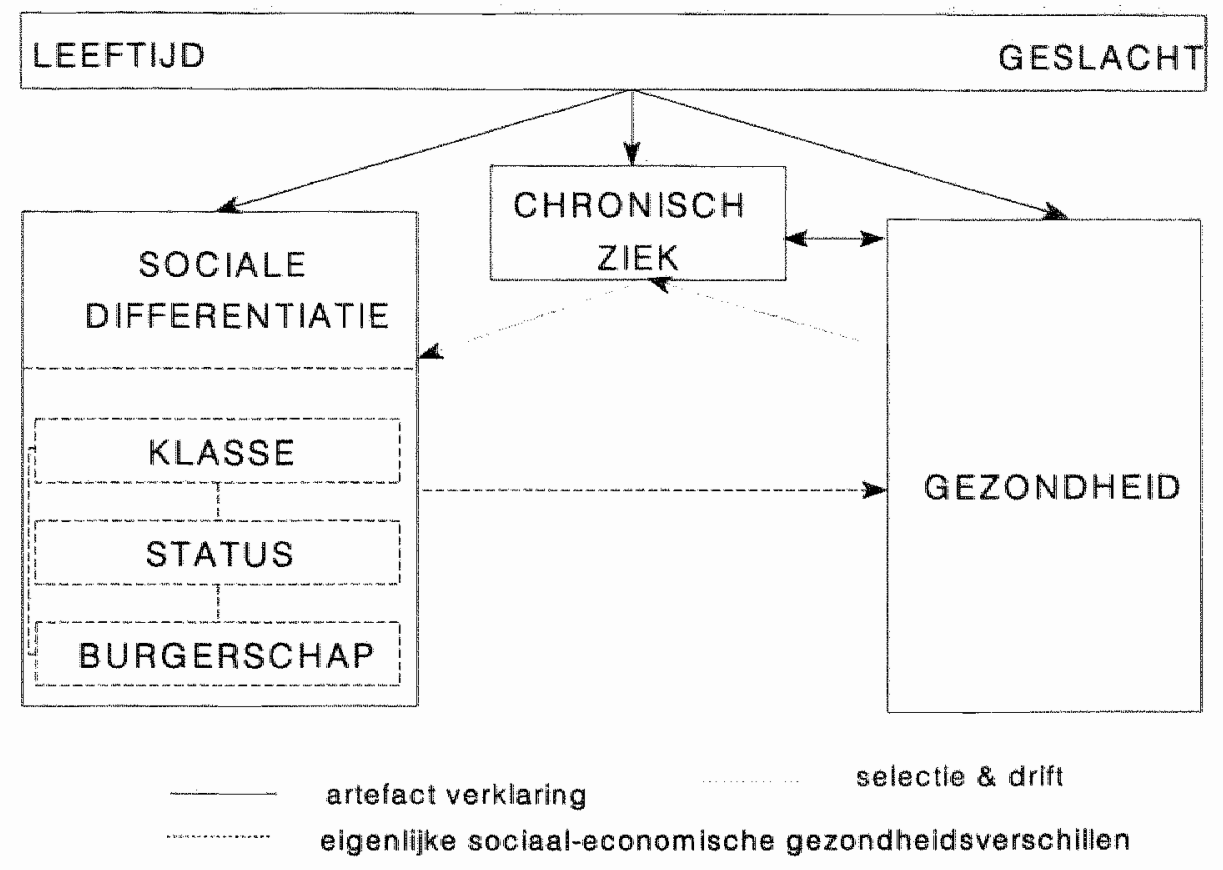

Zoals hiervoor werd betoogd zijn leeftijd en geslacht als kenmerken van sociale differentiatie (stand) en als biologische determinanten van gezondheid te beschouwen. Omdat zij als zodanig de relaties van status, klasse en burgerschap met subjectieve gezondheid versluieren, worden al deze relaties getoetst onder uitschakeling van de leeftijd en geslacht. Het gaat immers niet aan verschillen in gezondheid, die samenhangen met verschillen in leeftijd en geslacht, te beschrijven als sociaal-economische verschillen. Vanuit theoretisch standpunt is strikt genomen deze procedure echter niet goed houdbaar. Volgens de cultureel-antropologische en de sociologische theorie vormen immers juist leeftijd en geslacht de basale kenmerken waarop socialle differentiatie berust, wat met betrekking tot de hier onderzochte gezond. heidsverschillen inhoudt dat hun invloed op gezondheid verloopt via de dimensies van socialle differentiatie: Klasse, status en burgerschap. In het geval deze redenering juist is, zullen leeftijd en geslacht geen verklaring meer toevoegen aan die welke reeds door de onderscheiden kenmerken van sociale differentiatie wordt gegeven. De plausibiliteit van deze redenering moge bliken uit de bevindingen van Verbrugge (1990), die aantoonde dat leefsituatie en leefstijl verantwoordelijk zijin voor de verschillen tussen mannen en vrouwen in objectieve en subjectieve gezondheid. In het onderhavige onderzoek wordt verwacht dat gezondheidsverschillen naar leeftijd en geslacht zijn terug te woeren op de samenhang van beide kenmerken met sociale differentiatie. Met andere woorden "er wordt aangenomen dat in een model waarin alle aspecten van sociale differentiatie zijn opgenomen, leeftijd en geslacht geen afzonderlijke verklaringen meer bieden voor sociaal-economische gezondheidsverschillen. 


\section{6 .2 Onderstellingen}

De viff belangrikste onderstelingen wan dit onderzoek kunnen nu als volgt worden geformu. leerd:

1. Leeftifd, geslacht en sociaal-economische gezondheidswerschillen

De relatie ussen de gemeenschappelike kenmerken war status, klasse en burgerschap (SES) enerzijds en subjectieve gezondheid anderzijds wordi volledig beschreven door leeftijd en geslacht.

2. Chronische ziekte en sociaal-economische gezondheidswerschillen

Bij constant houden van de effecten van leeftijd en gestecht en van het oordeel over de eigen gezondheid en het aantal lichamelike klachten, bestaat er tussen de gemeenschap. pelijke kenmerken van klasse, status en burgerschap (SES) enerzijds en de aamwezigheid van chronische aandoeningen anderzijds een duidelijke relatie.

3. Stalus, klasse, burgerschap en sociaal-economische gezondheidsverschillen Onder uitschakeling van leeftijd en gesiacht hebben status, klasse en burgerschap een van hun gemeenschappelijke kenmerken opleiding, inkomen en beroep (SES) onathankelijk effect op subjectieve gezondheid.

4. Sociale gelaagdheid, leeftij, geslacht en sociaal-economische gezondheidsverschilen De effecten van leeftijd en geslacht op sociaal-economische gezondheidsverschillen verdwijnen wanneer alle kenmerken voor sociale gelaagdheid zijn gebruikt om verschillen in gezondheid te verklaren.

5. Interacties tussen kenmerken ven respectievelikk klasse, status en burgerschap en sociaateconomische gezondheidsverschillen

Twee modellen worden ontwikkeld om verschillen in gezondheid tussen de sociale lagen te beschrijven. Enerzijds worden de verschillen toegeschreven aan de cumulatie van adversieve of juist gezondheidbevorderende eigenschappen van de kenmerken van de klasse, status en burgerschap en anderzlids aan de sociale consistentie van de gebruikte indica. toren. 


\section{$3.1 \quad$ Inleiding}

De hiervoor geformuleerde onderstellingen geven slechts globaal het mechanisme aan dat verantwoordelijk is voor sociaal-economische gezondheidsverschilen. Toetsing van deze onderstellingen beantwoordt weliswaar de vragen naar de basale mechanismen waarop sociaal-economische gezondheidsverschillen en hun onderlinge samenhang berusten, maar geeft geen inzicht in de precieze wijze waarop deze mechanismen werken. De literatuur op dit gebied biedt evenmin veel houvast. Er wordt in beschreven dat er verbanden bestaan tussen status, klasse en burgerschap enerzilds en gezondheid anderzijds (Söderfeldt, Danermark, Larsson 1989; Lahelma, Volkonen 1990; Spruit 1990; Diderichsen 1990; Leclerc, Lert, Fabien 1990; Whuk-Lipinski 1990; Kunst, Mackenbach 1992; CBS/EUR 1992), maar er word nauwe. lijks ingegaan op de vraag waarom deze verbanden bestaan (Uitee 1988; van der Lucht 1992 ; Wilkinson 1990;1986).

Een nauwgezette beschrijuing van de relaties van status, klasse en burgerschap met gezondheid zou deze mechanismen nader kunnen preciseren. Echter, eenmaal met behulp van bepaalde bevolkingsgegevens beschreven, kunnen deze specificaties niet meer op hetzelfde materiaal worden getoetst. Door met meer steekproeven uit dezelfde bevalking te werken. kunnen verbanden die voor éen bestand worden beschreven, in andere worden getoetst.

De relatie tussen sociale differentiatie en gezondheid kan bovendien vrij zwak en statistisch nauwelijks aantoonbaar zijn. Bij gebruik van gegevens uit éen steekproef uit de Nederlandse bevolking bestaat dan de kans dat over het bestaan en de aard van deze relaties ongeldige conclusies worden getrokken. Echter, indien in steekproeven, die op verschillende tijdstippen uit de Nederlandse bevolking zijn getrokken, telkens dezelfde zwakke, per steekproef statistisch niet overtuigende "relaties worden gewonden, dan zijn deze zwakke relaties op grond van hun stabiliteit wel serieus te nemen. Immers, zouden zij niet bestaan, dan zou hoogstwaarm schijnlikk de richting van deze zwakke relaties per steekproef verschillen. Bij vijf onafharkelikke steekproeven is bifvoorbeeld de kans dat de richting van toevallige relaties steeds dezelfde is. veel kleiner dan vijf procent $\left(.5^{5}=.031\right)$. Bij een toetsingsdrempel wan $10 \%$ respectievelijk $5 \%$ is volgens de binomiaalverdeling de kans, dat de onderzochte relatie zlch in twee van vijf onafhankelijke steekproeven voordoet, $7 \%$ respectievelijk $2 \%$. De kans dat deze relatie in meer dan twee steekproeven aantoonbaar is, is voor beide drempelwaarden kleiner dan éen procent. Alle onderzochte samenhangen kunnen op deze wijze op stabiliteil worden getoetst, hetgeen de resultaten aan overtuigingskracht doet winnen, omdat de "power" wan de test wordt verhoogd. In dit onderzoek is voor deze werkwijze gekozen (Galtung 1967).

\subsection{Databestanden}

Voor de analyses in dit onderzoek is gebruik gemaakt van de surveys van het Leefsituatie onderzoek (LSO) uit 1974, 1977, 1980 en 1983 van het Centraal Bureau voor de Statistiek (CBS) en van het Panelonderzoek naar de gezondheid van de Nederlandse bevolking in 1981 en 1983 van de vakgroep Medische Sociologie van de Rijksuniversiteit Limburg. Voor deze onderzoeken zijin 'random' steekproeven uit de Nederlandse bevolking getrokken van 18 jaar 
en ouder. In het survey in 1977 lag de ondergrens op 15 jaar en in het Panelonderzoek mochten de respondenten in 1981 niet ouder zin dan 65 jaar.

Ondanks het feit dat in de surveys de non-response met name in de grote steden wrij hoog is (1ot 60\%) en in het panelonderzoek door de steekproeftrekking de bevolking ten plattelande lets is oververtegenwoordigd, ziln de steekproeven representatief voor de Nederlandse bevol. king. De kenmerken van deze steekproeven zijn elders beschreven (CBS 1975, 1978, 1980, 1984a, 1984b, Adriaanse, Drop, Halfensi, Philipsen 1981: Halfens, Drop. Philipsen 1983). Tabel I geeft oen over zicht van de non-response in de onderscheiden bestanden.

Tabel I Aantallen ondervraagde personen en hoofden van huishoudens in de gebruikte steekproeven.

\begin{tabular}{|c|c|c|c|c|c|c|}
\hline \multirow[b]{2}{*}{ BESTANO } & \multirow[b]{2}{*}{ JAAP } & \multicolumn{2}{|c|}{ TOTALE STEEKPROEF } & \multicolumn{3}{|c|}{ HOOFDEN WAN HUISHOUDEN } \\
\hline & & $\begin{array}{c}\text { PRESPONSE } \\
\text { N }\end{array}$ & $\begin{array}{l}\text { \% NON- } \\
\text { PRESPONSEE }\end{array}$ & N & $\begin{array}{l}\text { \% PER } \\
\text { BESTAND }\end{array}$ & $\begin{array}{l}\text { \% VAAS } \\
\text { TOTAAL }\end{array}$ \\
\hline survey & 1974 & 4906 & 28.2 & 1966 & 41 & 21 \\
\hline sunvay & 1977 & 4159 & 29.7 & 1767 & 43 & 19 \\
\hline sumey & 1980 & 6813 & 38.7 & 3097 & 53 & 33 \\
\hline survey & 1983 & 3987 & 35.1 & 1610 & 40 & 17 \\
\hline paneler & 1981 & 1278 & 42.2 & 404 & 46 & 4 \\
\hline panel"83 & 1983 & 1193 & & & & \\
\hline TOTAL & & 21716 & & 9525 & 45 & 95 \\
\hline UTVRAL PAHEL & 1981 & & & 193 & 54 & 2 \\
\hline NIEUW PANEL & 1983 & & & 253 & 81 & 3 \\
\hline \multicolumn{2}{|c|}{ RLLE STEEKPFOEVEN } & & 9971 & 46 & 100 & \\
\hline
\end{tabular}

Besloten is geen poging te doen een perfecte weersplegeling van de Nederlandse bevolkins to verkrijgen door middel van weging van respondent-categorieën in de verschillende databe standen. Bij deze aantallen heeft weging slechts een gering effect op de uiteindelijke resulta ten. Bovendien is het niet duidelijk is thoe geldig deze weging is bij multivariate relaties.

In dit onderzoek wordt zo veel mogelik het Leefsituatieonderzoek uit 1983 gebruikt orn ver schillen in subjectieve gezondheid te beschrijuen en nader wit te werken. In dit onderzoel waren thet merendeel van de gebruikte variabelen voorhanden. De gevonden relaties worder getoetst op de steekproeven, die in de periode van 1974 tot 1983 voor dat onderzoek uit di Nederlandse bewolking zijn getrokken en op het Panelonderzoek naar de gezondheid van di Nederlandse bevolking uit 1981 en 1983. In deze periode hebben zich de gevolgen wan twe oliecrises doen voelen, en werd anderzijds de verzorgingsstaat in deze periode voltooid. Qu sociaal-economische ontwikkeling is deze periode van 10 jaar niet te kenschetsen als stabiel c rustig. Het is evenwel te verwachten dat de mechanismen die ten grondslag liggen aa sociaal-economische gezondheidsverschillen in deze periode niet zijn veranderd; wel kunne de condities voor gezondheid of ongezondheid die door deze mechanismen worden geimpl ceerd in de loop van deze periode in frequentie zijn toe- of afgenomen.

Een studie naar de relatie tussen sociale differentiatie en gezondheid vooronderstelt vanzel sprekend dat beide kenmerken aan de onderzochte eenheden of respondenten zijn gemeter De gekozen opzet vereist bovendien dat de gegevens wit de onderscheiden bestanden onde ling vergelijkbaar zijn. In het onderzoek is dan ook veeli tijd en aandacht besteed aan d vergelijkbaarheid van de gegevens. Hieroncier wordt achtereenvolgens beschreven welk 
bewerkingen zijin uitgevoerd om het materiaal hanteerbaal en vergelijkbaar te maken en welke analysemethoden zijn gebruikt.

\subsection{Beperking tot hootden van huishoudens}

On de validiteit van de resultaten van onderzoek te kunnen bepalen, is het niet alleen van belang te weten of de te onderzoeken kenmerken geldig en betrouwbaar zijn gemeten, maar ook of de eenheden waaraan de kenmerken zijn gemeten, de respondenten, daadwerkelijk door deze kenmerken worden gekarakteriseerd.

Werkzoekenden, werklozen; arbeidsongeschikten en gepensianeerden kunnen niet op basis van hun beroep worden geclassificeerd, evenmin als veel Nederlandse vrouwen die, zeker tot het eind van de jaren zeventig. in vergelijking tot vrouwen in andere Europese landen, weinig actief waren op de arbeidsmarkt. Bovendien bliven Nederlandse vrouwen in opleiding achter bij mannen. De traditionele indicatoren voor het bepalen van sociaal-economische status (SES) zijn op hen derhalve niet goed toepasbaar. Dit probleem wordt wel met proxy"s opgelost, bijvoorbeeld door vrouwen de status van hun echtgenoten toe te kennen of door mensen zonder werk te classificeren op basis van hun laatste werkkring. Dit is evenwel geen bevredigende methode nu de vraagstelling zich juist richt op de mechanismen, die verantwoordelijk zijn woor sociaal-economische gezondheidsverschillen. In dit geval dienen SES en subjectieve gezondheid adequaat aan de onderzochte persoon zelf te worden gemeten. Immer's, verschillen tussen echtelieden zouden juist als zodanig een reden kunnen zijn voor gezondheidsverschillen (Bosma, Appels, Sturmans e.a. 1991).

Opleiding, beroep en inkomen hebben als kenmerken van individuele sociaal-economische status slechts betekenis als ze op de respondent zelf betrekking hebben. Dit is slechts het geval voor hoofden van huishoudens, de volwassen man of vrouw die het meest bijdraagt aan de inkomsten van het huishouden. Oak dan nog dienen pensionering, arbeidsongeschiktheid en werkloosheid als aparte categorieën te worden opgenomen in de classificatie van beroepsgroepen waartoe de respondent behoort. Het is immers niet erg reëel om mensen die langere tijd niet meer op de arbeidsmarkt actief zijn, nog het prestige van hun voormalige beroep toe te kennen. Door het onderzoek tot hoofden van huishoudens te beperken, kan de indicering van de positie in de sociale gelaagdheid worden gebaseerd op individuele kenmerken van respondenten. Deze sociale positie kan nu zonder meer in verband worden gebracht met de gezondheid van de respondent, het andere individuele kentmerk dat in deze studie centraal staat.

Door deze selectie bestaan de steekproeven wrijwel geheel (meer dan 80 procent) uit mannen. De vrouwen in deze bestanden hebben met elkaar gemeen dat zil het beuwedeel genereren van het inkomen van het huishouden waar ze deel van uitmaken. Dit inkomen kunnen ze zich zowel door betaalde arbeid als door uitkeringen (alimentatie, bijstand) of vermogem verwerven. Gezien de discriminatie van gehuwde vrouwen op de arbeidsmarkt zijn de meeste vrouwen die in dit anderzok zijn opgenomen owerwegend alleenstaand of alleenstaande ouder. Ze zijn ofwel jong, hoog opgelleid en nemen deel aan het arbeidsproces of ze zijn oud en verweduwa. Vrouwen met een lage opleiding, die geen beroepsarbeid verrichten en gehuwd zijn met een man met een hoge opleiding komen niet voor in dit onderzoek, evenmin trouwens langdurig werkloze marnen van wie de partner werkt of werkende mannen die minder verdienen dan hun partner. Wel zijn er onder de respondenten mannen die langdurig werkloos en gehuwd zijn en van wie de partner geen betaalde arbeid verricht.

Hoewel de keuze voor hoofden van huishoudens als de eenheid van onderzoek een tamelifk aspecifieke selectie van vrouwen of vrouweriollen oplevert, is er toch van afgezien alle vrouwen uit het onderzoek te verwijderen. Kennelijk is in de Nederlandse samenleving de sociale 
status en positie van wrouwen zodanig. dat zij nauwelijks te winden zijn in positio- en statusrollen welke met die van mannen zijn te vergeliken. Als er dan een gering aantal vrouwen overblijt voor wie status en posities wel vergelikbaar zijn met die van mannen, moeten zij niet als anomalieën uit het onderzoek worden verwijderd; daardoor zouden sociaal-economische gezondheidsverschillen op basis van de geslachtsrol worden verdoezeld. Bovendien heeft Verbrugge (1990) aangetoond dat de verschillen tussen mannen en vrouwen in envaren gezondheid en in het gebruik van gezondheidsvoorzieningen vrijwel verdwijnen wanneer wordt gecontroleer w voor werk, samenwonen en sociale participatie.

In Tabel I wordt een overzicht gegeven van de steekproeven waarop de analyses zijn uitgevoerd, het percentage hoofden van huishoudens in de gebruikte bestanden en het percentage hoofden van huishoudens per bestand. Het percentage hoofden van huishoudens varieert per bestand van 40 tot 53 procent. In het Panelonderzoek zijn 882 personen zowel in 1981 als in 1983 onderzocht. Van hen waren $404(46 \%)$ hoofd van een huishouden. Opvallend is dat in het panelonderzoek de uitval iets hoger en met name de vervanging groter was in de categorie van hoofden van huishoudens. Het totaal aantal ondervraagde personen bedraagt 21.646, van wie $46 \%$ (9971) hoofd van een huishouden is. Daarvan zijn er 8844 in het onderzoek betrokken. De jongste hoofden van huishoudens zijn amper 20 jaar, de oudsten zijn in de negentig. De mediaan van de leeftijdsverdeling in de verschillende bestanden ligt rond de 42 tot 45 jaar.

\subsection{Onderlinge afstemming van de data-bestanden}

Hoewel de Leefsituatieonderzoeken van het CBS een gemeenschappelijke noemer hebben, is hun inhoud zeer verscheiden. Niet alleen zijn in de opeenvolgende jaren over hetzelfde onderwerp verschillende vragen gesteld, waardoor een bepaalde reeks van vragen de ene keer wel en de andere keer niet zijn gebruikt, ook variëren de antwoordcategorieën op dezelfde vraag over de jaren. Bovendien zijn in 1980 in het Leefsituatieonderzoek door het CBS en het Sociaal Cuitureel Planbureau (SCP) verschillende vragenlijsten gebruikt, waardoor voor een deel van de respondenten bepaalde gegevens ontbreken of vragen op een lets andere wijze zijn gesteld. Daamaast verschilt de volgorde van de vragen per bestand. Geldigheid en betroum baarheid van dezelfde vraag kunnen daardoor per onderzoek verschillen.

Om de onvangrijke bestanden met elkaar vergelijkbaar te maken en snel de aanwezige variabelen te kunnen opsporen, ziln de volgende bewerkingen uitgevoerd:

1. Herbenoemen van variabelen

2. Hercoderen van antwoordcategorieèn van variabelen

3. Rubriceren van variabelen

4. Creëren van nieuwe bestanden

\section{Ad 1. Herbenoemen van variabelen}

Alle variabelen, per bestand variërend van 600 tot 900 zijn herbenoemd. Hun nieuwe naam verwijst nu rechtstreeks naar het nummer van de vraag in de vragenlijst.

\section{Ad 2. Hercoderen van antwoordcategorieen wan variabelen}

Alle variabelen zijn gehercodeerd om zodoende in alle bestanden gelijke antwoordcodes te verkrijgen. Om vergissingen bij interpretaties te voorkomen is in elk bestand de richting van de codering gellikgeschakeld: een laag getal betekent steeds dat het attribuut niet of in geringe mate aanwezig is of dat men het met de voorgelegde uitspraak (zeer) oneens is, een hoog getal geeft altijd aan dat het attribuut (in rume mate) voorhanden is of dat men het met het gestelde (zeer) eens is. Voor de variabelen die in dit onderzoek worden gebruikt, zijn vervolgens de antwoordcategorieen zo op elikaar afgestemd dat zij ondering zijn te vergelijken. 
Deze laatste bewerking leverde in een aantal gevallen grote problemen op. Ter illustratie daarvan kan het volgende voorbeeld dienen. Alle vragen in Tabel Il gaan ower lawaai in de werkomgeving. Het is echter onduidelik hoe de indeling in 'ja' / 'nee' zich verhoudt tot de vijt categorieen op de schaal 'erg veel' t/m 'nooit'. Al helemaal onduidelik is hoe de vragen naar de aanwezigheid van lawaai in de werkomgeving zich verhouden tot de vraag naar de last van dal lawaai met antwoord categorieen 'fa' / 'ja samenvoegen van antwoord categorieën is daarom niet te geven.

Omdat mensen die last hebben van het lawaai op hun werk de vraag naar de aanwezigheid van dit lawaai waarschijnlijk wel positief zullen beantwoorden, kan de procentuele verdeling van de antwoorden op de 'ja'/ 'nee' vraag als richtsnoer dienen bij hercodering. Om na te gaath in welke mate de antwoordcategorieen op de vraag uit het survey uit 1977 (Tabel II) zich van elkaar onderscheiden, zijn de vragen binnen de rubriek 'werkomstandigheden' gekwantificeerd met behulp van correspondentie-analyse (HOMALS). Ditzelfde is gedaan voor de vraag uit de CBS-versie van het survey in 1980. Met behulp van deze analyse is de relatieve afstand van de antwoordcategorieën per gegevensbestand te bepalen. Antwoordcategorieën met kwantificaties die dicht bij elkaar liggen, kunnen dan worden samengevoegd omdat zij meer "op elkaar lijken" dan antwoordcategorieën met een grote onderlinge afstand (Gifi 1981).

Tabel II Procentuele verdelingen optimale schaling van antwoordcategorieèn op vragen in de surveys naar lawaai op het werk.

\begin{tabular}{lllcc}
\hline & ANTWOORD- & \multicolumn{3}{c}{ OPTIMALE } \\
WRAAG: & CATEGORIE & $\%$ & SCHAALWAARDE CODERING \\
- Werkt U in een lawaailge amgeving? & ja & 31 & 1 & 1 \\
(survey 1974; wraag 63) & nee & 69 & 0 & 0 \\
- Is er veel lawaal in UW werkomgeving? & erg veel & 12 & 1.04 & 1 \\
(survey 1977; vraag 321.1) & tamelijk veal & 19 & .38 & 0 \\
& niet zoveel & 19 & .29 & 0 \\
& weinig & 23 & -.20 & 0 \\
- Heeft U zelf last op het werk van lawaai? & vrijwel noolt & 27 & -.76 & 0 \\
(survey 1980 versie CBS; vralag 17g) & ja, soms & 22 & 1.25 & 1 \\
& nee & 64 & .14 & 0 \\
- Werkt U in een lawaaierige omgeving? & ja & 26 & -.50 & 0 \\
(survey 1980 versie SCP; vralag 85) & nee & 74 & 0 & 1 \\
- Werkt U in een lawaaierige omgeving? & ja & 26 & 1.24 & 0 \\
(survey 1983; vraag 34) & nee & 74 & -.40 & 0
\end{tabular}

Op basis wan deze bewerkingen was het mogelijk de antwoordcategorieën van de vragen uit de verschillende bestanden te comprimeren en de meeste vragen uit de verschillende ander. zoeken met eenzelfde domein onderling vergelijkbaar te maken. In de bijlage zijn de frequentie-verdelingen opgenomen van de gebruikte variabelen waarvan de antwoordcategorieenn in de verschillende bestanden op elkaar zijn afgestemd.

\section{Ad 3. Rubriceren van variabelen}

De variabelen zijn gegroepeerd in categorieën, die woor dit onderzoek relewant zijn.

Onder klasse worden kenmerken van huisvesting, woonomgeving, werksituatie en bezit ondergebracht. Onder status worden kenmerken van geloofsovertuiging, politieke voorkeur en riskante gewoonten gerubriceerd, alsmede kenmerken van de vrije-tijdsbesteding en onder 
burgerschap burgerlịke staat, lidmaatschap van werenigingen, het doen van vrijwilligerswerk en het gebruik van maatschappelike voorzieningen. Schema. A (Bijlage) geeft een owerzicht van de variabelen die in de onderscheiden rubrieken in de verschillende bestanden voorkomen.

\section{Ad 4. Credren van nieuwe bestanden}

Van de gehercodeerde en herbenoemde gegevens ziln nieuwe ruwe data bestanden gemaakt met een daerbil behorende beschriving die door SPSSX is te lezen. Op deze wijze kunnen ook andere en nieuwe versies van programma's voor statistische analyse worden gebruikt.

\section{$3.5 \quad$ Indicatoren}

Uit het voorgaande volgt dat de wijze waarop de centrale begrippen in dit onderzoek worden geindiceerd, sterk afhankelik is van hetgeen in de gebruikte bestanden aan vragen is opgeno men. Deze omstandigheid brengt met zich mee dat op sommige terreinen de indicering gelukkiger is untgevallen dan op andere.

\subsubsection{Gezondheid}

Gezondheid is meer dan de afwezigheid van ziekte. Door gebruik te maken van subjectieve gezondheidsmaten wordt enerzijds recht gedaan aan de kwaliteit van leven, welke nauw samenhangt met gezondheid, en anderzijds aangesloten bij hetgeen in de medische wereld onder ziekte wordt verstaan omdat subjectieve gezondheidsmaten een sterke samenhang vertonen met de aanwezigheid van ziekten. Subjectieve gezondheid is in de onderscheiden bestanden met behulp van de vragenlijst methode op drie verschillende wijzen geindiceerd en gemeten:

a. de aanwezigheid van chronische ziekten of langdurige aandoeningen

in de surveys is de aarwezigheid van chronische aandoeningen vastgesteld aan de hand van vragen naar lichamelijke aandoeningen waar men het afgelopen jaar, langer dan drie maanden of vaker dan drie keer last van had. De vraag naar de aanwezigheid wan chronische aandoeningen levert doorgaans een geldige schatting op van mensen met langdurige lichamelijke aandoeningen (van den Bosch, Habbema, van der Maas e.a. 1988). In de CBS-versie van het survey uit 1980 is geen aanduiding voor een periode opgenomen en is de vraag uitgebreid met 'de gevolgen van een ongeval'. In het Panelonderzoek is rechtstreeks gevraagd naar de aanwezigheid van chronische aandoeningen of ziekten. Uit het Panelonderzoek blijkt dat wie eenmaal een chronische aandoening heeft, daaraan niet voor altijd lijdt. Var de in totaal 160 respondenten, die in 1981 of in 1983 zeiden een chronische aandoening te hebben, waren er 67 (32\%) die tussen 1981 en 1983 hetzil van een chronische aandoening genazen, hetzij een chronische aandoening ontwikkelden.

Door de verschillende manieren van vragen varieert het percentage chronisch zieken onder hootden van huishoudens sterk. De conservatieve vraagstelling uit het Panelonderzoek levert $\pm 25 \%$ chronisch zieken op, terwijl in de surveys de proportie chronisch zieke hoofden van huishoudens varieert van $\pm 30 \%$ tot meer dan $50 \%$ (Tabel $1:$ Bijlage). Slechts in de surveys uit 1980 (versie CBS) en 1983 zijn de vragen over chronische aandoeningen door enkele respondenten niet beantwoord. 


\section{b. het "Oordeel over de Eigen Gezondheid" (OEG)}

Vanal 1977 in alle bestanden aanwezig. Van de vraag Hoe is alles bijeengenomen uw gezondheid?' (vijf antwoordcategorieën van 'zeer goed" $\mathrm{um}$ "zeer slecht') is uit de internationale literatuur bekend dat deze voorspellende waarde heeft vool de mortaliteit en morbi. diteit over tamelijk lange perioden (Singer, Gartinkel, Cohen e.a. 1976; Mossey, Shapiro 1982; Kaplan, Camacho 1983; Kaplan, Kotler 1985; Kaplan, Barrel, Luslky 1988; Krzyzanowski Wysocki. 1986). Ook in een Nederlandse 10-jaars follow-up studie werd een sterk verband tussen de perceptie van de eigen gezondheid en stertte gevonden (Bosma, Appels, Sturmans e.a. 1991).

in het survey 1974 is naar de tevredenheid met de gezondheid gevraagd (5 punts-schaal). hetgeen het wat afwijkende patroon van scores verklaart. Deze vraag maakte deel uit wan een aantal vragen over tewredenheid met de leefsituatie". In de overige surveys was deze vraag er éen van een aantal die op gezondheid en het gebruik van gezondheidvoorzieningen betrekking hadden. In het Panelonderzoek is beide keren gevraagd "hoe beoordeelt U in het algemeen Uw gezondheid?" met categorieën "zeer slecht"(1) tot en met 'zeer gaed'(5). Deze laatste vraag komt overeen met de formulering zoals gebruikt door Kaplan en Camacho (1983).

Driekwart van de hoofden van huishoudens beoordeelt zijn gezondheid als goed of zeer goed of is er (zeer) tevreden mee. Nog geen twee procent beoordeelt zijn gezondheid als zeer slecht en rond de $5 \%$ als slecht (Tabel III).

Vrijwel alle ondervraagde hoofden van huishoudens (99.61\%) hebben deze vraag beantwoord. Gezien de geringe aantallen personen die hun gezondheid als matig of (zeer) slecht beoordeelden, zijn bij multivariate analyses deze antwcordcategorieën samengenomen.

c. de ervaren gezondheid (VOEG)

De door Dirken (1967) uit de Cornell Medical Index ontwikkelde Vragenlijst voor Onderzoek naar de Ervaren Gezondheid (VOEG) geeft een valide en betrouwbaar beeld van de huidige gezondheidstoestand, zoals deze in lichamelike klachten tot uiting komt (Joosten. Drop 1988; van Sonsbeek 1990). In de onderscheiden steekproeven zijn verschillende versies van de VOEG gebruikt. In de surveys 1974, 1977 en 1980 (SCP) en het panel 1981 is de korte of 21 -item VOEG toegepast, in het panel 1983 de lange VOEG (48-items) en in de overige bestanden is de mini-versie van de VOEG gebruikt (13-items). Uit een eerdere studie (Joosten, Drop 1987) is gebleken dat de lengte van de VOEG nauwelijks inwloed heeft op de invuling van de items, in dit onderzoek zijn uit de langere versies alleen de items uit de mini-VOEG gebruikt. De envaren gezondheid is derhalve in de verschillende bestanden op vrijwel dezelfde wijze gemeten.

i) Uitgaande van de onderstelling, dat het oordeel over de eigen gezondheid vooral verwiljst naar het oordeel over de kracht van hel eigen lichaam om ziekte af te weren, wordt aangenomen dat 'tevredenheid met de gezondheid" een sterkere relatie vertoont met het cordeel over de eigen gezondheid dan met het ervaren wan klachten. Deze aanname kon worden getoetst in het survey 1980 (versie CBS), omdat daarin alle drie wragen zilin opgenomein. De correlatie tussen 'tevredenheid met de gezondheid' en het 'oordeel over de gezondheid' is .76. die tussen 'tevredenheid' en 'ervaren klachten'.58. Bij controle op 'ervaren klachten' bedraagt de partielle correlatie tussen het' oordeel over de eigen gezandheid' en de 'tevredenheid over de gezondhelid' .85; wordt gecontroleerd op het "oordeel over de eigen gezondheid', dan is de partielle correlatie tussen 'tevredenheid over de eigen gezondheid' en 'ervaren klachten'. 21. Hieruit mag worden geconcludeerd dat 'tevredenheid met de gezondheid' als een proxy woor het 'oordeel over de eigen gezondheid' is te beschouwen. 
Minder dan eenderde van de hoofden van thuishoudens heeft in de periode 1974 tot 1983 geen lichamelijke klachten; ongeveer eenderde rapporteent eén a twee klachten. Minder dan $5 \%$ wan de hoofden van huishoudens zegt meer dan 8 a 9 klachten te ervaren (Tabel V). In de periode 1974-1983 ligken zich geen systematische veranderingen in ervaren gezondheid voor te doen (Sikkel 1984).

In totaal heeft nog geen drie procent van de ondervraagden de VOEG niet ingevuld. De uitval is thet hoogst in 1974 en 1980. Gezien de scheefheid van de VOEG-verdelingen zijn deze in multivariate analyses logaritmisch getransformeerd.

\subsubsection{Sociale differentiatie}

Omdat de beschikbare surveys voor de jaren 1974, 1977, 1980 en 1983 alleen dwarsdoorsnedes uit de Nederlandse bevolking geven en het Panelonderzoek shechts een periode van twee jaren beslaat, kunnen individuele stijging en daling op de maatschappelijke ladder en veranderingen in klasse en burgerschap niet (surveys) of mauwelijks (panel) worden nagegaan. Deze beperking brengt met zich mee dat wel de "status quo' van de respondenten, maar niet de geschiedenis die daaraan vooraf ging, bekend is.

Zoals hiervoor is uiteengezet word" in deze studie de sociale differentiatie op twee manieren gerepresenteerd. Enerzijds doar de sociaal-economische positie die mensen in de samenleving innemen: Socialat-Economische Status (SES), anderzijds doar de onderscheiden begrippen (status, klasse, burgerschap), die duiden op de mechanismen waarlangs de sociale gelaagdheid van de samenleving tot stand komt.

De Sociaal-Economische Stafus wordt geindiceerd door een combinatie van het bereikte ondierwijsniveau, de beroepsgroep en thet inkomen (Coleman 1978), waarover in elk van de bestanden gegevens voorhanden zijn.

Status komt tot uiting in lemands gedragingen, spraak en kleding. Beide laatste kenmerken worden doorgaans niet in survey-onderzoek onderzocht. Wel is in de verschillende surveys gevraagd naar de activiteiten die in de vrijetijd worden uitgevoerd, naar rook-en drinkgedragl. naar stijl van leven. De levensstijl staat echter niet op zichzelf; daarin komen bepaalde normen en waarden tot uiting. Politieke voorkeur, gelootsovertuiging, tijdschriften of boeken die worden gelezen kenmerken daarom ewenzeer de status als riskante gewoonten en andere markeringen van sociaal-economische gelaagdheid. Sociale status wordt daarom geindiceerd door politieke voorkeur en kerkelijke gezindte, door vrijetijdsbesteding en riskante gewoonten zoals roken en drinken.

Klasse duidt op die aspecten van de sociale differentiatie, die betrekking hebben op condities waaronder men in materieel opzicht leeft. Sociale klasse wordt daarom geindiceerd met aspecten van woon - en werkomstandigheden en met bezittingen waarover men beschikt. Urbanisatiegraad en provincle worden hier opgevat als aspecten van de woon-en werkomgeving.

Burgerschap differentieert de leden wan de samenleving naar de mate waarin zij deel uitmaken van en deelnemen aan de samenleving. Zoals hiervoor is uiteengezet komt burgerschap tot uiting in de rechten die lemand ten opzichte van de samenleving kan laten gelden en in de mate waarin deze rechten worden gerealiseerd. Burgerschap wordt daarom geíndiceerd door burgerlijke staat, lidmaatschap van verenigingen, wijwilligerswerk en gebruik wan maatschappelike voorzieningen, zoals Kruiswerk, sociale of psychische hulp-en dienstverlening. 


\begin{tabular}{|c|c|c|c|c|c|c|c|}
\hline \multicolumn{5}{|c|}{ SURVEY } & \multicolumn{3}{|c|}{ PANEL } \\
\hline BESTAND: & $1974^{2}$ & 1977 & $\begin{array}{l}1980^{\circ} \\
\text { CBS }\end{array}$ & $\begin{array}{l}1980 \\
S C P\end{array}$ & 1983 & 1981 & 1983 \\
\hline \multicolumn{8}{|l|}{ OEG-score } \\
\hline zeer slecht & 9.0 & 1.6 & 2.4 & 1.9 & .9 & .4 & 4 \\
\hline slecht & 10.7 & 6.3 & 6.3 & 6.3 & 45 & 4.4 & 3.2 \\
\hline gaat wel & 26.9 & 17.7 & 19.8 & 18.0 & 17.9 & 16.0 & 18.5 \\
\hline goed & 30.6 & 45.1 & 45.1 & 42.7 & 48.2 & 56.7 & 57.4 \\
\hline zeer goed & 22.8 & 29.3 & 26.4 & 31.0 & 28.5 & 22.4 & 20.5 \\
\hline GEMDD. SCORE & 3.48 & 3.94 & 3.87 & 3.95 & 3.99 & 3.96 & 3.94 \\
\hline ST. DEV. & 1.21 & 93 & .96 & .96 & .85 & .77 & .74 \\
\hline $\mathbb{N}$ & 1887 & 1758 & 1587 & 1493 & 1609 & 499 & 498 \\
\hline \multicolumn{8}{|l|}{ ONTBREKENDE } \\
\hline WAARNEMINGEN & 79 & 9 & 12 & 6 & 1 & 0 & 0 \\
\hline
\end{tabular}

\subsection{Methoden}

\subsection{Inleiding}

Voor de beschrijving van relaties tussen bepaalde kenmerken waarbij rekening wordt gehouden met de invloed van alle overige kenmerken, kan het best gebruik worden gemaakt van partiële correlatierekening. De vaststelling van de afzonderlijke en de gezamenlijke effecten van status, klasse an burgerschap op subjectieve gezondheid, onder uitsluiting van effecten wan andere kenmerken, zou eenvoudig kunnen gebeuren met hiërarchische gewone regressie (Ordinary Least Square) voor gepercipieerde en ervaren gezondheid (ordinaal meetniveau) en logistische regressie voor chronisch ziekte (nominaal meetniveau). Er doen zich echter een aantal problemen voor waardoor deze analyse-methoden niet zonder meer kunnen worden toegepast. In de eerste plaats vertonen status, klasse en burgerschap als uitingen van sociale differentiatie onderlinge samenhang. Hierdoor is de interpretatie van de afzonderlijke regressio. coëfficienten moeilijk omdat deze gedeeltelijk berustlen op de bijdrage wan de andere begrippen. De bijdragen van klasse, status en burgerschap zullen daarom alzonderlik en gecombineerd worden geanalyseerd. In de tweede plaats zijn de gevolgen van sociale differentiatie in status, Klasse en burgerschap zo divers, dat ze doorgaans niet op basis van slechts een kenmerk kunnen worden geindiceerd. Tenslotte is, zowel door verschilen in formulering als door heterogeniteit in antwoordcategorieën in de verschillende surveys (nominaal dichotoom en ordinaal), het meetniveau van de indicatoren binnen eenzelfde domein ongelijk. Hierdoor is de assumptie van gelijke spreiding van de waarnemingen op de indicatoren onwaarschijnlijk. Hoewel heteroscedasticiteit de regressieanalyses niet ongeldig maakt; werliezen ze aan zeg* gingskracht omdat de nauwkeurigheid van de schattingen afneemt (Tabashnik, Fidell 1989, p.83). Bovendien wordt hierdoor de vergelijking van de resultaten van dezelfde analyses in verschillende steekproeven vrijwel onmogelijk.

Om deze problemen te ondervangen en om te vermijen dat slechts enkele (willekeurige) kenmerken kunnen worden gebruikt om sociale gelaagdheid en haar uitingen in status, klasse 


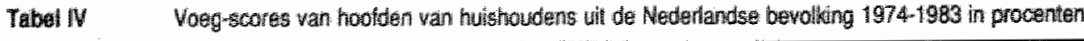

\begin{tabular}{|c|c|c|c|c|c|c|c|}
\hline & SUFVEY & & & & & PANEL & \\
\hline BESTAND: & 1974 & 1977 & $\begin{array}{l}1980 \\
\text { CBS }\end{array}$ & $\begin{array}{l}1980 \\
\text { SCP }\end{array}$ & 1983 & 1981 & 1983 \\
\hline \multicolumn{8}{|l|}{ VOEG-score } \\
\hline 0 & 34.0 & 27.1 & 29.2 & 29.5 & 31.2 & 23.6 & 28.7 \\
\hline 1 & 19.5 & 18.3 & 18.3 & 18.9 & 19.9 & 18.6 & 16.5 \\
\hline 2 & 14.0 & 14.5 & 13.1 & 13.3 & 13.6 & 15.2 & 12.8 \\
\hline 3 & 10.0 & 11.3 & 9.7 & 10.2 & 9.2 & 8.8 & 12.6 \\
\hline 4 & 6.4 & 7.7 & 8.1 & 6.8 & 8.2 & 8.0 & 8.1 \\
\hline 5 & 4.9 & 5.9 & 5.3 & 6.6 & 5.1 & 7.8 & 5.3 \\
\hline 6 & 3.3 & 5.0 & 4.6 & 5.0 & 4.6 & 5.2 & 3.1 \\
\hline 7 & 2.3 & 3.6 & 3.6 & 3.8 & 2.8 & 3.6 & 2.6 \\
\hline 8 & 2.1 & 2.9 & 2.8 & 2.1 & 2.0 & 3.0 & 4.5 \\
\hline 9 & 1.2 & 1.6 & 2.3 & 1.4 & 1.9 & 2.0 & 1.6 \\
\hline 10 & 1.0 & 1.0 & 1.4 & 1.1 & 8 & .8 & 1.6 \\
\hline 11 & .6 & .6 & 1.2 & .5 & 3 & 1.8 & .8 \\
\hline 12 & .5 & .4 & .3 & .5 & 4 & .6 & 1.2 \\
\hline 13 & .1 & & .2 & .3 & .1 & .8 & .4 \\
\hline GEMIDD. SCORE & 2.16 & 2.56 & 2.61 & 2.49 & 2.30 & 2.91 & 2.72 \\
\hline ST. DEV. & 2.57 & 2.64 & 2.83 & 2.69 & 2.56 & 2.96 & 2.95 \\
\hline $\mathbb{N}$ & 1870 & 1732 & 1550 & 1459 & 1579 & 499 & 491 \\
\hline \multicolumn{8}{|l|}{ ONTBREKENDE } \\
\hline WAARINEMINGEN & 96 & 35 & 49 & 39 & 31 & 0 & 8 \\
\hline
\end{tabular}

en burgerschap te indiceren, zijn indexen geconstrueerd. Voorwaarde bij de constructie van deze was, dat uit de indexen de antwoorden op de oorspronkelijke kenmerken moeten zijn af te leiden (d.w.z. dat ze geldig zijn) en dat hun spreiding in de gebruikte surveys in principe gelijk dient te zijn. Door de heterogeniteit in meetniveau van de basis-variabelen zijn parametrüsche technieken woor de index-constructie minder geschikt. Daarom is doorgaans gekozen voor een non-parametrische benadering.

Vanwege het multi-dimensionale karakter van de sociale gelaagdheid in de samenleving is gekozen voor een miet-parametrische principale componentenanalyse (HOMALS en PRINCALS) en voor uni- en meerdimensionale schaaltechnieken (MOKKEN-schaalanalyse (Meerling 1981). Door de constructie van indexen worden de effecten van systematische bronnen van onbetrouwbaarheid geëlimineerd (antwoordgeneigdheid, sociale wenselijkheid) en onsystematische fouten in beantwoording gereduceerd. Omdat de niet-parametrische PCA ook kan worden opgevat als het toekennen van optimale schaalwaarden, wordt door deze analysemethode de vergelijkbaarheid van de gegevens eveneens verhoogd. De verschillende methoden worden hieronder kort beschreven.

\subsubsection{Metrische en niet-metrische Principale Componentenanalyse}

Bij Principale Componenten Analyse (PCA) worden kenmerken van respondenten tamelijk summier, maar wel volledig beschreven. Deze versimpeling vindt plaats door na te gaan of de beschreven kenmerken zodanig met elkaar samenhangen, dat deze door éen component kunnen worden weergegeven. Is er geen enkele samenhang tussen de beschreven kenmerken, dan beschrijft elk kenmerk zichzelf en is er dus geen reductie mogelijk. Beschrijft een component meer dan één variabele of kenmerk, dan bindt deze component de gemeenschap- 
pelijke variatie, hetgeen tot uiting komt in zijn Eigenwaarde. Deze Eigenwaarde, gedeeld door het totaal aantal kenmerken of variabelen in de gegevensmatrix "geeft de proportie van de door die component of dimensie verklaarde variantie weer. Aangezien bil oen volledige beschrijving de proportie verklaarde variantie éen is "geeft het verschil tussen de wolledige beschrijving en de representatie door de gebruikte componenten de mate van niet-passendheid of 'stress' weer (wan Rijckevorsel, de Leeuw 1988; Kim, Mueller 1978a, 1978b).

Doorgaans is men niet geïnteresseerd in de beschrijving van een aantal willekeurige kenmerken, maar wil men kenmerken die op eenzelfde domein betrekking hebben op een simpeler manier beschrijwen, $d . w . z$. er de belangrijkste componenten uit weergeven. Het gaat er dan niet om de kenmerken zo volledig mogelijk, maar om ze zo simpel mogelijk te beschrijen. liefst in éen of twee, hooguit drie componenten of dimensies. Deze componenten dienen samen dan wel een belangrijk deel van de oorspronkellike gegevens adequaat weer te geven. Ook voor elke variabele of kenmerk afzonderlijk kan worden aangegeven hoe goed deze door de onderscheiden componenten of dimensies wordt beschreven (communaliteiten $h^{2}$ ). Bovendien kan voor elk kenmerk of elke variabele worden uitgedrukt hoe goed deze door elke component wordt beschreven (lading; discriminatiemaat). De lading van een variabele op een (gestandiaardiseerde) component of dimensie kan worden opgevat als de correlatie van die variabele met de component, de communaliteit van een varlabele is te beschouwen als de multiple correlatie van die variabele met alle overige variabelen in de gegevensmatrix. Hoge ladingen, communaliteiten of discriminatiematen wijzen dus op een adequate beschrijuing van de variabelen door de gebruikte componenten (Kim, Mueller 1978a,b).

Bij metrische PCA vormen de waarden van de in de analyse gebruikte variabelen een geor. dende schaal $(0<1<2 \ldots)$ met gelijke afstanden tussen de meetpunten en mel een althans theoretisch bekende verdeling in de populatie. Op basis van deze bekende verdeling, kunnen de gevonden relaties tussen de kenmerken optimaal worden beschreven door aan te nemen dat de relatie tussen de variabele en de component die deze beschrift lineair is, dat de variatie die resteert na beschrijving van de variabelen met behulp wan de componenten normaal verdeeld is en dat tussen de restvarianties van de variabelen na beschrijing met behulp van de gedefinieerde componenten, geen samenhang bestaat. Deze optimalisering gebeurt dus op basis van aannamen over hoe de componenten onderling en met de oorspronkelijke variabelen samenhangen, ongeacht de objecten waaraan is gemeten: de componenten zijn derhalve steekproef onafhankelijk.

Bi) variabelen met niet-metrische of niet-geordende antwoordcategorieën zijn de afstanden fussen de verschillende waarden op de schaal ongelik of hebben ze geen betekenis zoals het geval is wanneer de variabele verschillende kenmerken mest die atzonderlijk of gezamenlijk kunnen voorkomen. Om toch op dezelfde wijze als hierboven samengevat te worden in componenten is het noodzakelijk de kenmerken of antwoordcategorieën optimale schaalwaarden te geven op één of meer componenten. Daarbij worden de antwoordcategorieèn op een variabele en de onderlinge samenhang tussen variabelen bepaald door na te gaan in welke mate deze tegelijkertijd aan eenzelfde object (i.c. respondent) worden waargenomen. Optimale scores worden nu gevonden door onder bepaalde condities beurtelings aan personen met een gelijk kenmerken-profiel gelijke scores toe te kennen en aan kenmerken de gemiddelde kenmerken-scores van de personen te geven, totdat het verschil tussen deze scores bij twee opeenvolgende bewerkingen onder een tevoren bepaalde grenswaarde liggem. De zo gevonden optimale schaalwaarden zijn echter steekproefafhankelijk, orndat ze tegelijkertijd zijn berekend op de relatie tussen de objecten waaraan is gemeten en op thet gezamerilijk voorkomen van bepaalde antwoordicategorieen. Bij metrische analyses kon worden geabstraheend wan de objecten waaraan is gemeten. De schalen die de optimale scores weergeven zijn, doordat ze de samenhang tussen de antwoordcategorieên of kenmerken weergeven, ook 
principale componenten. De discriminatiemaat geeft de correlatie weer tussen de opümaal getransformeerde categorieèn of kenmerken en de component. Door de steekproefafhankelike oplossing zijn de schaalwaarden niet zonder meer te gebruiken in andere steekproeven. Indien de steekproeven op dezelfde wijze uit dezelfde populatie zijn getrokken. zouden de schaalwaarden niet sterk wan elkaar mogen verschillen. In het volgende hoofdstuk wordt dif woor een aantal kenmerken nagegaan.

De niett-metrische PCA is verricht met bethuip van HOMALS (nominale gegevens) en PAINCALS (ordinale gegevens), de metrische PCA met behulp van SPSSX4 en SPSS/PC3. De bewerkingen zilin uitgevoerd op een VAX8650, respectievelik op IBM compatibele PC's.

\subsubsection{Schaalanalyse volgens Mokken.}

Bij eendimensionale schalen volgens Mokken wordt nagegaan of de aarwezigheid van én kenmerk de aanwezigheid van andere kenmerken impliceert. Zo onderstelt bijvoorbeeld thet bezit van een tweede huis het bezit van eem eigen huis voor vaste bewoning en het zeer waarschijnilike bezilt van een auto. De zo gevonden schaal wordt geëvalueerd met behulp van Loevingers $\mathrm{H}$, die het aantal 'foute' scores (schending van de implicatie-onderstelling) ten opzichte van hel verwachte aantal 'foute' scores weergeeft. Als ondergrens voor deze parame. ter is de waarde 30 gekozen. Anders dan bij hel schaalmodel volgens Guttman, waar de score op één kenmerk die van andere determineent, is het model van Mokken probabilistisch van aard; een bepaalde score maakt de scoring op een aantal variabelen of kenmerken waarschijnlijk. Het Mokken model houdt in dat de waarschijnijikheid van voorkomen van een bepaaide score op een variabele groter wordt bij het toenemen van de schaalwaarde. De analyses zijn uitgevoerd met het programma MSP op een IBM-compatibele PC.

\subsubsection{Multiple Regressio Analyse}

De vraagstellingen, zoals deze aan het begin van deze paragraaf zijn geformuleerd, vragen alle naar de relatie tussen sociale positie en gezondheid van individuen wanneer rekening wordt gehouden met kenmerken van klasse (leefsituatie), status (leefstil), burgerschap (sociale participatie) en met de standsfactoren leeftijd en geslacht. Nu de kenmerken van sociale gelaagdheid, klasse, status en burgerschap door de metrische en niet-metrische PCA als continue, normaal verdeelde grootheden kunnen worden gerepresenteerd en gezondheid als een binaire (aan- of afwezigheid van chronische aandoeningen) of een ordinale (oordeel eigen gezondheid, ervaring eigen gezondheid) grootheid, ligt de keuze voor multivariate analysetechnieken en met name voor regressieanalyse, voor de hand (Everitt, Dunn 1983)

Bowendien kan met behulp van partiële correlaties antwoord worden gegeven op de vraag of de verschillen in gezondheid tussen de sociale lagen (mede) worden veroorzaakt doordat leeftijd en geslacht zowel gezondheid als sociale gelaagdheid beïnvloeden. Zou de partiële

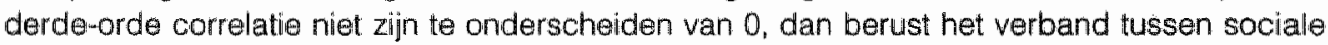
laag en gezondheid op een artefact. In hel geval de verschillen in gezondheid tussen de sociale lagen thet resultaat zijn van processen van drift en selectie, dan moet dit blijken uit een sterk verband tussen langdurige of chronische aandoeningen en sociaal-economische positie. waarbij de relatie tussen sociale positie en de ervaring van de eigen gezondheid of het oordeel over de eigen gezondheid dient te verdwijnen.

\subsubsection{OLS Regressie}

Bij regressie wordt geprobeerd om éen variabele te beschriven als een gewogen som vam andere variabelen. Naarmate de samenhang van de te beschriven variabele met een van de beschrijwende variabelen groot is, zall de variatie van de variantie die overblijft na de beschrij- 
wing gering zijn. Ondersteld wordt dat de beschrijvende variabeten onderling geen of weinig samenhang vertonen en dat de restvariantie normaal is verdeeld.

Modeimatig kan dit worden weergeven alls:

Gezondheid $=\beta 1 *$ stand $+\beta 2 *$ klasse $+\beta 3 *$ status $+\beta 4$ * burgerschap + ruis (model y)

Hierin is $\beta$ de samenhang van de gestandaardiseerde beschrivende variabelen met de eveneens gestandaardiseerde gezondheidswariabelen. $\beta$ varieert tussen - 1 negatieve samenhang en 1. De hoogte van deze $\beta$ 's kan tussen de gebruikte bestanden verschillen maar indien het gevonden verband stabiel is, zouden ze in de verschillende bestanden duidelijk van o (geen samenhang) moeten verschillen. Net als bij de klassieke PCA wordt de beschrijving geoptimalim seerd door de ruis, gedefinieerd als het kwadraat wan de afstand tussen de geschatte waarde voor gezondheid en de geobserveerde waarde zo klein mogelijk te maken. Er mogen geen restricties bestaan ten aanzien van de waarden die de te beschrijven variabele mag aannemen. Dit maakt deze techniek wel geschilkt voor de OEG en de VOEG, maar onbruilkbaar voor de binaire variabele 'chronisch ziek'.

De coëfficiënt van determinatie geeft weer in welke mate het model een adequate beschriving is van de geobserveerde variatie (variantie [Gezondheid-ruis]/variantie [gezondheid]), vergelijkbaar met de communaliteit uit de PCA. De wortel van deze coefficiënt is de multiple correlatie tussen de parameters in het model en gezondheid.

In het vorige hoofdstuk is gesuggereerd dat standskenmerken, zoals leeftijd en geslacht een meer generiek effect hebben dan kenmerken van klasse, status en burgerschap, die eerder gelijkwaardige maar verschillende aspecten van de sociale differentiatie beschrijven. De SESindex pretendeert eveneens daarvan een generiek kenmerk te zijn. Het is daarom van belang te weten in welke mate deze laatste twee aspecten van sociale differentiatie gezondheid beschrijven en vervolgens in welke mate klasse, status en burgerschap deze beschrijving aanvullen. Met behulp van hiërarchische regressieanalyse worden deze verschillende kenmerken wan sociale differentiatie na elkaar in de analyse opgenomen.

Met behulp van de grootheid $F$, waarin $R^{2}$, de verklaarde variantie is na toevoeging van $k$ lasse. status of burgerschap, $\mathrm{R}_{\mathrm{a}}^{2}$ de verklaarde variantie met alleen standskenmerken en $\mathrm{M}$ het aantal kenmerken voor klasse, status, respectievelijk burgerschap, $\mathbb{N}$ het aantal respondenten en $k$ het totaal aantal indexen en kenmerken dat in de regressievergelijking is gebruikt, kan worden getoetst of de toegewoegde termen de beschrijying van gezondheid verbetert (zie o.a. Tabach nik, Fidell 1989, p.157).

$$
F=\frac{\left(R_{i}^{2}-R_{a}^{2}\right) / M}{\left(1-R_{i}^{2}\right) /(N-k-1)} \quad(d f=M+N-k-1)
$$

Na inwoering van klasse, status en burgerschap kan de samenhang $(\beta)$ van gezondheid mat de SES-index geheel of gedeeltelik wegvallen, amdat de eerstgenoemde kenmerken een vollediger of betere beschrijving geven. In dat geval kan worden gesteld dat de samenhang tussen de generieke kenmerken van sociale differentiatie (de SES-index) worden 'veroorzaakt' door hun samenhang met de meer specifieke kenmerken in klasse, status en burgerschap. Deze specifieke kenmerken kunnen dan als 'oorzaak' van sociaal-economische gezondheidsverschillen worden gezien. Het is evenwel ook mogelijk dat de samenhang juist wordt versterkt bij inwoering van de meer specifieke kenmerken. In dat geval 'verklaren' ze niet de sociaal. economische gezondheidsverschillen, maar 'versluieren' ze eerder deze relatie.

Door deze analyses in de verschillende bestanden te herhalen kan de stabiliteit van de bevin dingen worden getoetst. 


\subsubsection{Logistische regressie}

Omdat de aanwezigheid van chronische ziekten of aandoeningen een binaire variabele is, wordt hier gebruik gemaakt van logistische regressie. In dit geval wordt niet het al of niet hebben van een chronische aandoening geschat, maar wordt in de steekproef de kans op het voorkomen van chronische aandoeningen geschat. De toetsingsgrootheden zijn hier analoog aan die in de gewone regressie maar berusten niet op de F- maar op de $\chi^{2}$-verdeling. De mate waarin het geschatte aantal chronisch zieken alwijkt van het door de onderscheiden modellen verwachte aantal (de "likelihood ratio statistic' $G^{2}=2 \Sigma f_{o b s} \ln \left(f_{a b s} / F_{\text {exp }}\right.$ ), waarbil hier $f_{\text {ebs }}$ het gevonden aantal chronisch zieken is en $F_{\text {exp }}$ het door het model voorspelde aantal).

De likelihood ratio statistic $G^{2}$ geeft weer in welke mate het model een adequate beschrijving is van het gegevensbestand (variatie of frequenties volgens het model/variaties of frequenties zonder specificatie van het model). Naar analogie met OLS-regressie wordt hier de wortel van deze grootheid geinterpreteerd als ware het de multiple correlatie tussen de parameters in het model en de aanwezigheid wan chronische aandoeningen. Aangezien de grootheid $\mathrm{G}^{2}{ }_{\text {totagi }}$ de som is van alle mogelijke modellen, kan de extra verklaring van het interactie-model worden getoetst door na te gaan in welke deze bijdraagt aan de reductie in $\mathrm{G}^{2}\left(\mathrm{G}_{\text {diff }}^{2}=\mathrm{G}_{\mathrm{ini}}^{2}-\mathrm{G}_{\text {addi }}^{2}\right.$ df $=\mathrm{M})$.

De toetsing van de bijdrage van de SES-index, status, klasse en burgerschap aan de beschrijving van de aanwezigheid van chronische aandoeningen verloopt analoog aan die van de OEG en de VOEG.

Alle regressie-analyses zijn steeds hiërarchisch uitgevoerd, dat wil zeggen eersit werden leeftijd en geslacht ingevoerd, dan regio en urbanisatiegraad, dan SES-index en vervolgens klasse of status of burgerschap. Daarna werden de variabelen voor de interactie-effecten in de analyse ingevoerd. Binnen de onderscheiden hierarchische stappen zijn de indicatoren voor deze mechanismen of modellen gelijktijdig ingevoerd, omdat er geen argument was op basis waarvan de ene indicator in de tijd vooraf zou gaan aan andere. Door deze werkwijze is in alle analyses bij het vergelijken van de onderscheiden modellen voor leeftijd en geslacht gecorrigeerd. De gestandaardiseerde regressiecoëfficiënten geven de relatie weer tussen de gebruikte indicatoren en gezondheid.

Bij toetsing is gekeken of de gevonden relaties duidelijk van het toeval verschilden $(p<10)$ als ook of de gevonden relaties stabiel waren qua teken. Door deze werkwijze kunnen zwakke, maar consistente relaties worden opgespoord.

\subsubsection{Bewerkingen materiaal}

De resultaten zullen worden gepresenteerd voor hoofden van huishoudens voor wie geldige gegevens beschikbaar zijn. Respondenten voor wie gegevens over het oordeell over de eigen gezondheid (OEG), de ervaren gezondheid (VOEG) en de aanwezigheid van chronische ziekte ontbraken, zijn van de analyse uitgesloten. Dit geldt ook woor respondenten bij wie door helt ontbreken van gegevens over opleiding, beroep of inkomen geen SES-index kon worden geconstrueerd. Voor valiërend van $4.5 \%$ tot $20.9 \%$ vam de hoofden van huishoudens ontbreken in de surveys gegevens voor éen of meer van de deze SES-indicatoren. Vooral vragen over thet inkomen zijn niet beantwoord ( $3.7 \%$ tot $20.9 \%$ 'missing values'). Voor de beide andere SESindicatoren variëren deze percentages van $0 \%$ tot $2 \%$. Op grond van 'missing values' zijn vooral ouderen met een laag inkomen of mensen met een uitkering van de multivariate analy. ses uitgesloten. Hierdoor worden sociaal-economische gezondheidsverschillen eerder verzwakt dan aangezet.

De indexen vool werk- en woonomstandigheden, voor woonomgeving, vrijetijdsbesteding, belangstelling voor sport en cultuur en de indexen voor burgerschap, waarvan de constructie in het volgende hoofdstuk wordt beschreven, zijn per bestand gerangordend volgens de stan- 
daard-normaal verdeling. Hierdoor is de verdeling van de indexen over de bestanden vergelikbaar, echter, omdat er tussen de bestanden verschillen bestaan in aantal en aard van de bij de constructie gebruikte variabelen, varieent de betrouwbaarheid van de scores per bestand. De onderscheiden categorieên voor politieke voorkeur, kerkelijke gezindte en burgerlike staat werden als dummy variabelen gecodeerd. Ontbrekende waamemingen zijn vervangen door het gemiddelde van de desbetreffende index of dummy.

Als een belangrijke voonwaarde voor een adequate beschrijving van de relaties van de indexen van status, klasse en burgerschap met gezondheid geldt, dat ze zowel afzonderlijk (univariaat) als in hun onderlinge samenhang (multivariaat) niet al te sicheef of uitzonderlijk (uitbijters) zijn verdeeld. In geval van scheve verdelingen en/of uitbijters kunnen immers respondenten "die deze uitzonderlijke kenmerken bezitten de beschrijving van de sociaal-economische gezondheidsverschillen vertekenen. $\mathrm{Er}$ is getracht dit te voorkomen door de gebruikte variabelen te screenen op scheefheid en uitbijters en waar nodig deze te herhalen of hercoderen. Univariate uitbijters werden door de rangordening naar de standaard-normaalverdeling getranstormeerd: Weliswaar hadden enkele indices ook hiema nog waar den groter dan 2, maar zijn deze niet getrimd omdat ze een getrouwe afspiegeling vormen van de in de sociale werkelijkheid voorkomende ongelijkheden. Multivariate uitbijters werden per bestand opgespoord op basis van hun Mehanolobis afstand tot de overige respondenten in dat bestand. Per bestand bleken 10 tot 40 respondenten een te grote afstand tot de overigen te bezitten. Zij zijn eveneens van verdere analyse uitgesloten. Door deze laatste selectie werden voornamelijk hoofden van huishoudens uit de analyses verwijderd met weinig frequente politieke voorkeuren (met name klein en confessioneel rechts). Ook deze selectie lijkt geen risico op overschatting van saciaaleconomische gezondheidsverschillen met zich te brengen. Wel is hierdoor in dit onderzoek de sociale en culturele verscheidenheid van de Nederlandse samenleving nog verder ingeperkt. Overigens zij opgemerkt dat bij analyse bleek dat de uitsluiting van deze categorieün de analyses nauwelijks beïnvloedde. 


\section{INDICES VOOR SOCIALE DIFFERENTIATIE: STATUS, KLASSE EN BURGERSCHAP}

De vele kenmerken van sociale differentiatie zijn eercier contingent dan dat ze op dwingende wijze samenhangen. Zij geven elk op zichzelf genomen maar een klein deel weer van de socialle differentiatie. Door per rubriek gemeenschappelijke aspecten van de kenmerken van status, klasse en burgerschap te beschrijven, kunnen deze concepten aan geldigheid en betrouwbaarheid winnen. Door deze beschrijving met indices wordt ook het probleem van de vergelijkbaarheid van de indicatoren tussen de bestanden opgelost. De constructie van deze indices wordt in dit hoofdstuk behandeld. Een overzicht van de gebruikte variabelen en indices wordt gegeven in schema B in de bijlage. In de tekst wordt met Romeinse cijfers naar tabellen in de tekst verwezen en met Arabische cijfers naar tabellen die in bijlage zijn opgenomen.

\subsection{Een index voor sociaal-economische differentiatie}

In de vorige paragrafen zijn opleiding. beroepsgroep en inkomen al aangewezen als indicatoren woor sociaal-economische differentiatie (Schema 3),

Schema 3 Indicatoren van sociale gelaagdheid en hun meting

Opleiding * Hoogst genoten opleiding van het hoofd van het huishouden (1: lager onderwijs; 2: lager beroepsonderwijs; 3 : mavo; 4 : havo, wwo, mbo; 5 : hbo, wo.)

Beroep * Ordening van beroep van het hoold van het huishouden volgens de CBS classificatie naar Sociale Groep (1 vrije beroepen - 9 werkloos)

Inkomen * Inkomen uit arbeid, bezit of uitkering van het hoofd en de overige leden van het huishouden (in guldens per jaar).

Opleiding is ingedeeld in vijf categorieen, voor sociale groep is de indeling van het CBS gebruikt, aangevuld met gegevens over de bron van het inkomen. Inkomen is in de diverse surveys op verschillende wijze geoperationaliseerd en gecategoriseend. In de Leefsituatieonderzoeken is gevraagd naar het netto maand- of jaarinkomen, in het Panelonderzoek naar het bruto jaarinkomen. Het aantal klassen, waarin het inkomen werd verdeeld en de breedte van deze classificaties, verschillen per onderzoek. Alleen in het survey van het CBS uit 1980 werd naar het bedrag gevraagd.

Zoals bekend is inkomen een tamelijk onbetrouwbare indicator van de financiele mogelijkheden van een respondent. Niet alleen kan het netto maandinkomen zijn 'vervuild' met tijdelijke premies en toeslagen, ook is onduidelijk of rekening is gehouden met mogelijk fiscale voor- en of nadelen en met subsidies, zoals kinderbijslag, huursubsidie en dergelijke. Evenmin is duidelijk of inkomsten uit vermogen in de opgave van het inkomen zijn verdisconteerd (van Berkel-van Schaik, Tax 1990). Door de variabele breedte van de inkomenscategorieën zijn bovendien de gegevens over het inkomen niet goed vergelijkbaar. Bij dit alles is nog geen rekening gehouden met effecten van de geldontwaarding. Om deze redenen vormt per bestand het inkomen slechts een grove indicator van de financiële armslag.

De indeling naar sociale groep, onder andere gebaseerd op het prestige van het uitgecefende beroep , de voor het beroep benodigde opleiding en het aan het beroep verbonden inkomen, 
is in de surveys vrijwel gelijk en kon uit de gegevens van hel Panelonderzoek worden afgeleid. Hoewel woor deze indicator de vergelikbaarheid over de bestanden geen problemen oplevert, doet zich bij deze indicator het principiele probleem voor, dat de indeling van het CBS naar sociale groep slechts op werkenden toepasbaar is. Hierdoor valt de niet of niet meer op de arbeidsmarkt actieve bevolking buiten deze indeling. Omdat een indeling via het laatst uitgeoefende beroep of het beroep van de (overteden) partner de huidige status quo niet adequaat kan weergeven, zijn de niet-actieven ingedeeld op de voomaamste bron van inkomen: pensioen, vermogen of uitkeringen via de werkloosheids-, arbeidsongeschiktheids- of algemene bijstandswet. In Tabel $/$ zijn de onderscheiden categorieen gerangordend op basis van de niet-metrische PCA. (HOMALS) met opleiding en inkomen.

Tabel V Beroep (sociale groep) in de onderscheiden steekproeven uit de Nederlandse bevolking

\begin{tabular}{|c|c|c|c|c|c|c|c|}
\hline \multirow[b]{2}{*}{ BESTANO: } & \multicolumn{5}{|c|}{ SUPVEY } & \multicolumn{2}{|l|}{ PANEL } \\
\hline & 1974 & 1977 & $\begin{array}{l}1980 \\
\text { CBS }\end{array}$ & $\begin{array}{l}1980 \\
\text { SCP }\end{array}$ & 1983 & 1981 & 1983 \\
\hline
\end{tabular}

\section{Beroep of groep}

(geordend van hoog naar laag)

$\begin{array}{lrrrrrrr}\text { vrije beroepen } & 8.7 & 2.5 & .8 & 1.4 & 1.1 & 11.9 & 8.0 \\ \text { employée hoog } & 5.0 & 9.5 & 6.6 & 7.7 & 8.4 & 10.3 & 7.2 \\ \text { employée midden } & 17.3 & 20.2 & 17.8 & 16.0 & 16.1 & 20.4 & 19.4 \\ \text { zelfstandig } & & 4.0 & 4.5 & 3.8 & 3.2 & 3.6 & 3.6 \\ \text { employée laag } & 12.3 & 5.5 & 11.0 & 10.7 & 11.3 & 11.1 & 8.6 \\ \begin{array}{l}\text { meewerkend gezinslid. } \\ \text { onbekend }\end{array} & .4 & 1.5 & .6 & .6 & .6 & & \\ \text { studerend } & .8 & 1.4 & 1.5 & 1.8 & 1.1 & 1.2 & 1.2 \\ \text { militair. anders } & 3.6 & 1.6 & 3.7 & 2.8 & 2.6 & & \\ \text { landbouwers } & 4.5 & 2.8 & 3.0 & 2.9 & 2.4 & & \\ \text { arbeider } & 28.3 & 24.8 & 21.2 & 22.9 & 22.7 & 24.4 & 17.8 \\ \text { werkloos } & 1.2 & 1.1 & 1.4 & 1.5 & 4.3 & 4.4 & 6.6 \\ \text { pensioen } & 12.9 & 11.4 & 13.7 & 16.1 & 14.8 & 4.4 & 7.4 \\ \text { huisvrouw } & 5.4 & 9.5 & 9.2 & 6.7 & 4.5 & .8 & 10.8 \\ \text { arbeidsongeschikt } & & 4.2 & 5.0 & 5.3 & 6.6 & 7.3 & 9.2 \\ & & & & & & & 499 \\ \text { TOTAAL. } & 1950 & 1767 & 1583 & 1498 & 1610 & 495 & 499 \\ \text { ONTBP. WAARNEMINGEN } & 16 & & 16 & & & 4 & \end{array}$

In Tabel $V$ is goed te zien dat het Panelonderzoek is beperkt tot de bevolking van 20 tot 65 jaar (4.4\% gepensioneerden in 1981 en 7.4 in 1983 versus $15 \%$ in de landelijke steekproeven wan de surveys uit 1980 en 1983). Zoals op basis van deze verschillen kon worden verwacht, is het opleidingsniveau van de bevolking in de Panelonderzoeken hoger dan in de surveys: $21.23 \%$ heeft een opleiding op hbo of wo niveau versus $\pm 16 \%$ in de surveys (Tabel VI). In het Panelonderzoek is $15-22 \%$ van de ondervraagden hoger employée of een beoefenaar var een wrii beroep tegen $7-8 \%$ van de andervraagde hoofden van huishoudens in de surveys uit die 
Tabel M Ondenwijsniveau van de respondenten in de onderscheiden steekproeven uit de Nederlandse bevolking.

\begin{tabular}{|c|c|c|c|c|c|c|c|}
\hline \multirow[b]{2}{*}{ BESTAND: } & \multicolumn{5}{|c|}{ SURVEY } & \multicolumn{2}{|l|}{ PANEL } \\
\hline & 1974 & 1977 & $\begin{array}{l}1980 \\
\text { CBS }\end{array}$ & $\begin{array}{l}1980 \\
\text { SCP }\end{array}$ & 1983 & 1981 & 1983 \\
\hline \multicolumn{8}{|l|}{ Onderwijs: } \\
\hline alleen lo & 24.9 & 29.0 & 27.7 & 29.1 & 21.8 & 21.5 & 26.1 \\
\hline $\begin{array}{l}\text { lo en lbo } \\
\text { mavo }\end{array}$ & 30.5 & 35.8 & 18.7 & 24.9 & 16.4 & 24.1 & 18.5 \\
\hline havo $3 j r$ & 15.9 & & 4.8 & & 10.3 & 20.7 & 20.3 \\
\hline havo $4 \mathrm{jr}, \mathrm{mbo}$ wwo & 16.1 & 20.0 & 33.2 & 29.0 & 35.6 & 12.4 & 12.2 \\
\hline hbo, wo & 12.5 & 15.2 & 15.5 & 16.9 & 16.0 & 21.3 & 22.9 \\
\hline TOTAAL $(\mathbb{N}=100 \%)$ & 1923 & 1752 & 1576 & 1488 & 1602 & 498 & 498 \\
\hline ONTBA. WAARNEMINGEN & 43 & 15 & 23 & 10 & 8 & 1 & 1 \\
\hline
\end{tabular}

jaren (Tabel V).Ook het inkomen is in het panelonderzoek hoger (Tabel VII). De steekproef van het Panelonderzoek is over het algemeen iets beter geschoold, heeft hogere banen en is materieel wat beter af dan die van de surveys. Of hier sprake is van een leeftijdseffect dan well een andere wijze van steekproef trekken woor deze verschillen verantwoordelijk is, kan vanwege het ontbreken van de benodigde gegevens niet meer worden nagegaan.

In de tien jaar die de surveys bestrijken, is vooral het aantal mensen met een havo, wwo en middel bare beroepsopleiding toegenomen ( $v a n 16 \%$ in 1974 tot $35 \%$ in 1983 ; Tabel VIl). De stijging in het wetenschappelijk en hoger beroepsonderwijs is geringer (13\% tot $16 \%$; Tabell VII).

Tabel VII Gemiddeld jaarinkomen en spreiding (mediaan en interkwartiel-range) in de onderscheiden steekproeven vit de Nederlandse bevolking.

\begin{tabular}{|c|c|c|c|c|c|c|c|}
\hline \multirow[b]{2}{*}{ BESTAND: } & \multicolumn{5}{|c|}{ SUAVEY } & \multicolumn{2}{|l|}{ PANEL } \\
\hline & 1974 & 1977 & $\begin{array}{c}1980^{1)} \\
\text { Cess }\end{array}$ & $\begin{array}{l}1980 \\
\text { SCP }\end{array}$ & 1983 & 1981 & 1983 \\
\hline
\end{tabular}

\begin{tabular}{lrrrrrrr} 
jaarinkomen & netto & \multicolumn{3}{c}{ bruto } \\
& & & & & & & \\
mediaan & 20 & 23 & 22.8 & 26 & 29 & 35 & 35 \\
interkwartiel-range & 8 & 24 & 11.7 & 24 & 18 & 18 & 18 \\
TOTAAL & 1772 & 1701 & 1301 & 1364 & 1320 & 399 & 419 \\
$\begin{array}{l}\text { ONTBREKENDE } \\
\text { WAARNEMINGEN }\end{array}$ & 194 & 65 & 298 & 134 & 290 & 100 & 80
\end{tabular}

1) inkomen in hele guldens. In de overige bestanden zijn inkomens-categoneen gebruikt 
In het survey uit 1983 is het aantal werklozen in vergelliking tot de eerdere steekproeven bijna drie maal zo groot (1.5\% in 1980, 4.3\% in 1983); volgens het Panelonderzoek is er een stijging van $2 \%$ (van $4.4 \%$ in 1981 tot $6.6 \%$ in 1983; Tabel $\mathrm{W}$ ). Het aantal arbeidsongeschikten is tussen 1977 en 1983 met $2.4 \%$ toegenomen van $4.2 \%$ tot $6.6 \%$ in thet Panelonderzoek is tussen 1981 en 1983 hel aantal arbeidsongeschikten met een toegenomen tot $9.2 \%$ (Tabel V). Dit laatste ciffer vormt waarschijnijk een onderschatting omdat, wanwege de zeer hoge mortaliteit en morbiditeit onder arbeidsongeschikten (Philipsen. Halfens 1983), deze categorie verantwoordelijk is woor een aanzienlijke panel-mortaliteit. Voor de vraagstelling van dit onderzoek is voorts van belang dat de panel-mortaliteit het geringst is in de hoogste sociale groep.

Uit de hier gepresenteerde gegevens is af te leiden dat, ondanks de in alle gevallen random getrokken steekproeven, de verschillende studies niet zonder meer mel elkaar vergelikbaar zijn. Veranderingen in de Nederlandse samenleving in de periode die door deze surveys wordt bestreken, alsmede verschillen in vraagstelling en operationalisatie zijn hier debet aan. In het vorige hoofdstuk is uiteengezet dat vergelijkbaarheid van de indicatoren is bereikt door per bestand de hoofden van huishoudens via PCA optimaal te schalen (HOMALS) op de hierboven besproken variabelen. Op basis hiervan ziln in alle bestanden de respondenten gerangordend naar de gemeenschappelike kenmerken van opleiding, beroep en inkomen (SES-index). Door deze werkwijze zijh weliswaar de algemene weranderingen die in de Nederlandse samenleving tussen 1974 en 1983 hebben plaats gevonden niet meer te achterhalen, maar worden wel per bestand alle hoofden van huishoudens op grond van deze drie kenmerken zo goed mogelijk ingedeeld wan hoog naar laag.

De resultaten van deze analyse laten zien dat de onderscheiden beroepsgroep-, opleidings- en inkomenscategorieèn in alle studies op vrijwel dezelfde wijze worden geschaald. Uit Afbeelding 1 is duidelijk af te lezen dat de schaling van opleiding niet sterk verschilt van de oorspronkelijke rangorde van 1 tot $5(r= \pm .80)$ en dal de relatie met inkomen kromlijnig is Afbeelding 2 . Tussen het minimumloon en $11 / 2$ keer modaal neemt met de stijging van inkomen de sociaal-economische status evenredig toe. Boven twee keer modaal verhoogt een toename in het inkomen de sociaaleconomische status nauwelijks meer. In Afbeelding 2 is eveneens te zien dat de laagste inkomenscategorieën onbetrouwbaar zijn of in het geval er naar bruto maandinkomen werd gevraagd, geen duidelijke relatie met sociale positie vertonen. Tot deze categorieen behoren bijvoorbeeld studenten (hoge opleiding, geen inkomen) en gepensioneerden met een nietgeindexeerd pensioen (Afbeelding 3). In de verschillende bestanden ligt de correlatie tussen SES-index en inkomen rond.79. Doorgarans is het inkomen gemeten met een beperkt aantal categorieern. Hiermee is ook de SES-index berekend. Echter, ook indien het inkomen niet in categorieën maar in guldens wordt gemeten (CBS 1980), is de samenhang van de SES-index mét inkomen, gecorrigeerd voor uitbijters, hoog (.67). De onderscheiden categorieän in saciale groep zijn in de verschillende bestanden op overeenkomstige wijze gescoord."

1) Kendall's concordantiecoëficiënt W geeft aan in welke mate scores, die door verschillende beoordelaars (optimale schaalwaarden in de verschillende bestanden) aan dezelfde objecten (sociale groep categorieen) zijn toegekend, op eenzelfde onderliggend criterium zijn gebaseerd (Siegel 1974). 
Afbeelding 1 SES-index naar opleiding per bestand

SES-index

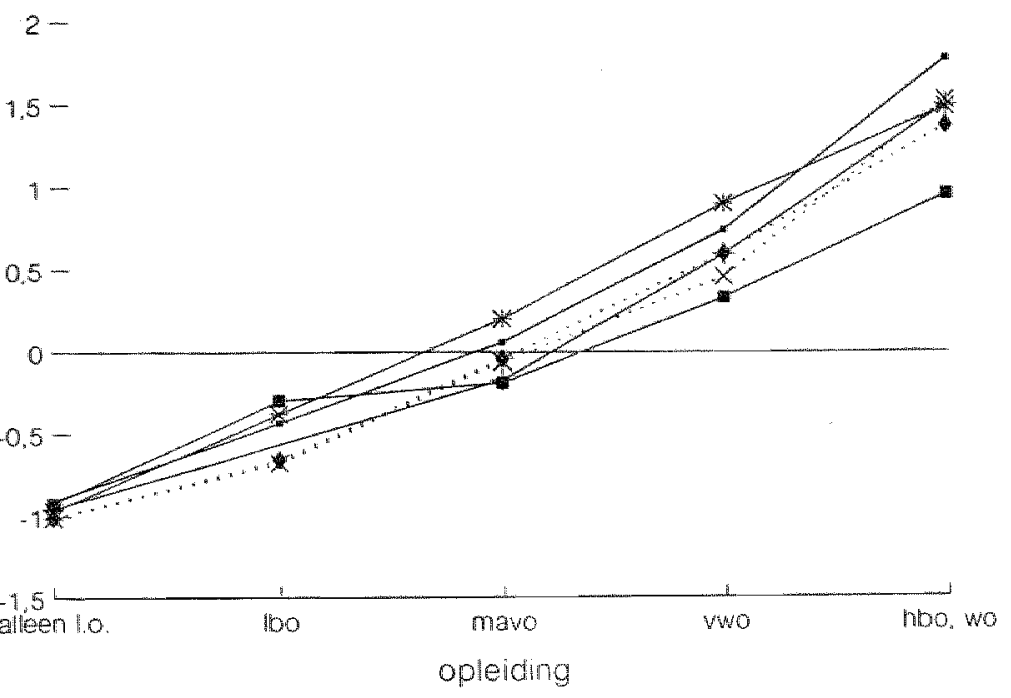

- survey $1974+$ survey 1977 * surveys 1980 suvey 1983 * panel 1981 panel 1983

Afbeelding 2 SES-index naar inkomen per bestand

SES-index

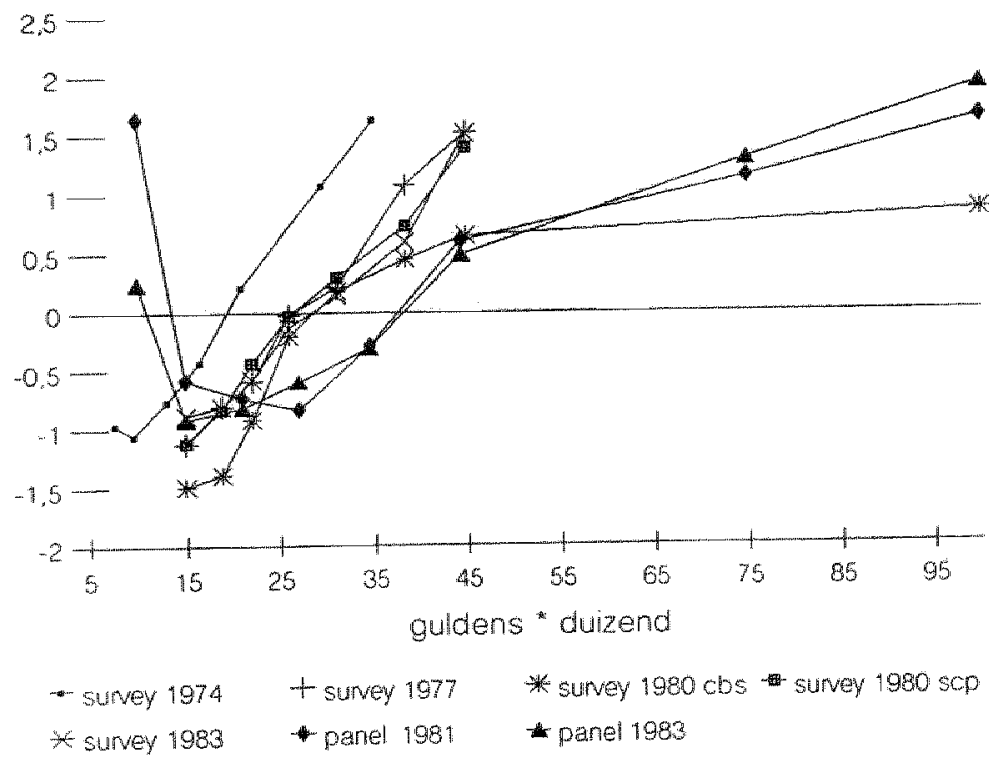




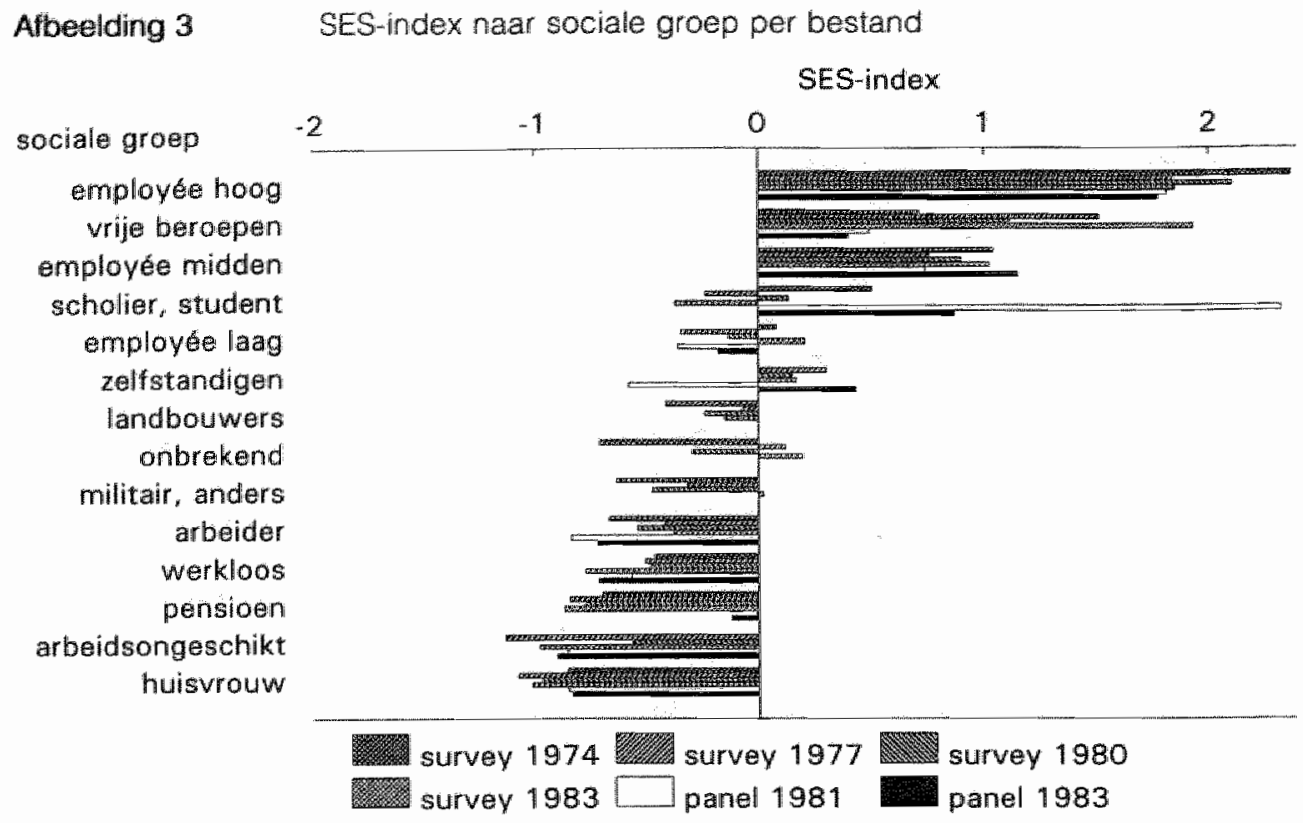

(Kendall's W= 98; $p<0.001 ;$ Afbeelding 3) De hier ontwikkelde index voor sociale differentiatie heeft in leder geval een hoge interne geldigheid. Ook de externe geldigheid is goed, gelet op de correlatie van 78 met de Ultee-Sixma schaal voor beroepsprestige, die in het survey 1977 is opgenomen. Omdat de hier ontwikkelde index voor saciaal-economische gelaagdheid ook toepasbaar is op werklozen, werkzoekenden en mensen die nog nooit hebben gewerkt of sinds lang niet meer werken, is het bereik ervan groter dan die van de schaal van Ultee-Sixma, welke is gebaseerd op echtparen en samenwonenden die op de arbeidsmarkt actief zijn. In Tabel $\mathrm{V}$ en Afbeelding 3 zijn de saciale groepen of beroepscategorieën geordend naar de gemiddelde rangorde over alle bestanden. Lit de ordening is af te leiden dat zelfstandigen wat betreft sociale rangorde vergelikkaar zijn met lagere employées en veel hoger worden geplaatst dam arbeiders. die in rangorde vergelijkbaar zijn met werklozen. Het feit dat voor verschillende categorieen handarbeiclers (bijvoorbeeld in de bouw) werkloosheid een 'normaal" verschinsel is, is hier wellicht debet aan. De sociale positie van landbouwers is eveneens vril laag.

De hier ontwikkelde schaal voor sociaal-economische differentiatie is in elk bestand normaal verdeeld (gemiddelde 0 , standaardafwijking 1) en de rangordening van de onderscheiden categorieën van de indicatoren, die deze index constitueren, is in de onderscheiden steekproeven dezelfde. Daarom kan worden gesteld dat deze index een tijd-en steekproef-onafhankelike rangordening vormt van individuen op kenmerken var sociale gelaagdheid.

\subsection{Indicatoren voor klasse}

De leefsituatie is geindiceerd door vragen over de woning, de woonomgeving, het bezit van duurzame consumptie en van luxe goederen (alle variabelen alleen in de surveys) en de werksituatie (in alle bestanden). 


\subsubsection{Woonsituatie}

In de surveys zijin elk jaar wragen opgenomen over de aard en kwaliteit van de woonrumte: De wragen over het soort huis waar men in woont (vrijstaand; eengezinshuis, flat, bejaarden- of studentencomplex), het aantal kamers waarover men beschikt, de hoogte van de woonlasten (huur onder aftrek van huursubsidie, hypotheek) en de aanwezigheid van mankementen zoals last van vocht, tocht en lawaai uit het survey 1983, konden met behulp van PCA volgens PRINCALS in een dimensie worden beschreven (Tabel VIII). Deze kan worden geinterpreteerd als kwaliteit van de woning. Aan de ene kant van deze component staan lawaaiige éen, twee en driekamerflats van slechte Kwaliteit (volgens de enquêteur) waar het tocht en vochtig is en aan de andere kant dure villa's (hoogste decielen voor woonkasten) met meer dan vier kamers. Aangezien in de verschillende bestanden de woonlasten niet op dezelfde wijze zijn geindiceerd en evenmin vergelijkbaar konden worden gemaakt, alsook het aantal kamers waarover het hoofd van het huishouden kan beschikken, aan de totale beschrijwing weinig bijdroeg, zijn deze kenmerken bij de meting van de woonkwaliteit niet gebruikt.

Tabell VIII Optimale schaalwaarden (HOMALS) voor de kenmerken van de kwalliteit van de woning in 1983

\section{Woningtype:}

vijistaande eengezinswoning $\quad 0.56$

eengezinswoning aangebouwd $\quad 0.15$

flat, boven- of benedenwoning $\quad-0.93$

woning met winkel en/of werk-

$-0.93 \quad$ voor studenten $\quad-0.93$

plaats 1.27

geen van beide $\quad 0.04$

deel van een bedrijtsgebouw $\quad-1.58$

bejaarden, verzorgingstehuiso $\quad-.88$

anders

$-62$

Kwaliteit woning:

aantal kamers

$\begin{array}{rr}1 & -1.09 \\ 2 & -0.78 \\ 3 & -0.47 \\ 4 & -0.15 \\ 5 & 0.16 \\ 6 & 0.47 \\ >6 & 0.79\end{array}$

woning in slechte staat

$\begin{array}{ccc} & 1 & -3.53 \\ & 2 & -1.44 \\ & 3 & -1.22 \\ & 4 & -0.51 \\ & 5 & 0.08 \\ & 6 & 0.18 \\ \text { zeer goede staat } & 7 & 0.64\end{array}$

Hinder en overlast: geluidshinder

zelden of ncoit

stankoverlast

wocht in huis

kou, tocht in huis
0.27

0.13

0.31

$-1.09$

$-0.47$

$-0.15$

0.16

.47

0.40 ja, soms

$-0.38$

$-0.37$

$-0.62$

$-0.14$ ja, vaak

$-1.23$

$-0.95$

$-1.78$

$-1.62$

\subsubsection{Kwaliteit van de woonomgeving}

De kwaliteit wan de woonomgeving is vastgesteld aan de hand van vragen over de aanwezigheid van verschillende voorzieningen in de buurt waar men woont (bakker, kruidenier en slager, huisarts, peuterspeelzaal, school, speelgelegenheid voor kinderen, postkantoor en bus- of tramhalte, groenvoorziening). Voor een deel zal de beantwoording van deze vragen verband houden met de urbanisatiegraad van het gebied waar men woont. Urbanisatiegraad is op zich zelf genomen echter al een kenmerk van de woonomgeving evenals de landstreek. Woont men in een van de 
grote steden in het Westen wan het land en ontbreken de genoemde voorzieningen dan is het voorzieningen-niveau in de buurt slechter dan indien men in het Noorden wan het land op het platteland woont. De drie noordelijke en de drie zuidelijke provincies, de provincies Noord-en Zuid-Holtand en Zeeland en de Oostelijke prowncies zijn als landstreken in de analyses opgenomen. Over het algemeen kan worden gesteld dat de genoemde voorzieningen voor het merendeel van de bevolking goed bereikbaar zijn (Tabel $X$ ). Met uitzondering van de groenvoorzieningen, tonen de verschillende voorzieningen onderling een hoge samenhang: alle voorzieningen, met uitzondering van de laatstgenoemde, laden hoog op én principale component die de helft van de variatie verklaart. Omdat de iterns een goede LIKERT schaal vormen (Crombach's $\alpha=85$ ). wordt de kwaliteit van de woonomgeving gemeten als de somscore van de aanwezige voorzieningen in de buurt.

Tabel IX Percentage hoofden van huishoudens naar de kwaliteit van de woonomgeving in de periode $1974-1983$

\begin{tabular}{|c|c|c|c|c|c|c|c|}
\hline \multirow[b]{2}{*}{ BESTAND: } & \multicolumn{5}{|l|}{ SUPVEY } & \multicolumn{2}{|l|}{ PANEL } \\
\hline & 1974 & 1977 & $\begin{array}{l}1980 \\
\text { CBS }\end{array}$ & $\begin{array}{l}1980 \\
\text { SCP }\end{array}$ & 1983 & 1981 & 1983 \\
\hline \multicolumn{8}{|l|}{ Voorziening } \\
\hline Bakker & 72.4 & & 91.0 & & 91.1 & & \\
\hline Groenteman & & & 89.9 & & 88.9 & & \\
\hline Bushaite, station & & & 94.5 & & 94.5 & & \\
\hline Postkantoor & & & 80.5 & & 81.9 & & \\
\hline Basisschool & 83.3 & & 91.1 & & 91.5 & & \\
\hline creches & 71.2 & 84.9 & & & & & \\
\hline Huisdokter & & & 78.5 & & 79.2 & & \\
\hline Café & & & 88.8 & & 81.5 & & \\
\hline Groenvoorziening & 65.4 & 67.8 & 88.7 & & 92.4 & & \\
\hline
\end{tabular}

\subsubsection{Werksituatio}

Ruim twee derde van de hoofden van huishoudens verricht betaalde arbeid (Tabel 5). lets meer dan tien procent van degenen die werken doet dat in ploegendienst.

De kwaliteit van de werksituatie is vastgesteld op basis van vragen over thet gemiddelde werktempo. wel of niet vuil werk, gevaarlijk, zwaar of eentonig werk (nooit - erg veel), en over lawaai en stank op de werkvloer (nee - ja). In het Leefsituatieonderzoek van het CBS uit 1980 waren de antwoordcategorieën op de eerste vragen beperkter (nooit "ja, soms, ja vaak).

In verband met het heterogene karakter van de kenmerken en het ordinale meetniveau, is gekozen voor schaling van de onderscheiden kenmerken van het werk in het Leefsituatieonderzoek 1983 via PCA volgens HOMALS. Er komt eén relatief sterke component (Eigenwaarde 0.33) natar voren, die vooral de kwaliteit van de werkomstandigheden weergeeft. Uit de schaalwaarden blijken reistijd, werken in ploegenarbeid, werken in een hoog tempo en eentonig werk niet of nauwelijks door deze component te worden weergegeven en demalve geen eenduidig betekenis te hebben met betrekking tot de kwaliteit van het werk (Tabel X). 
Tabel X Optimale schaalwaarden (HOMALS) voor kenmerken van het werk in 1983

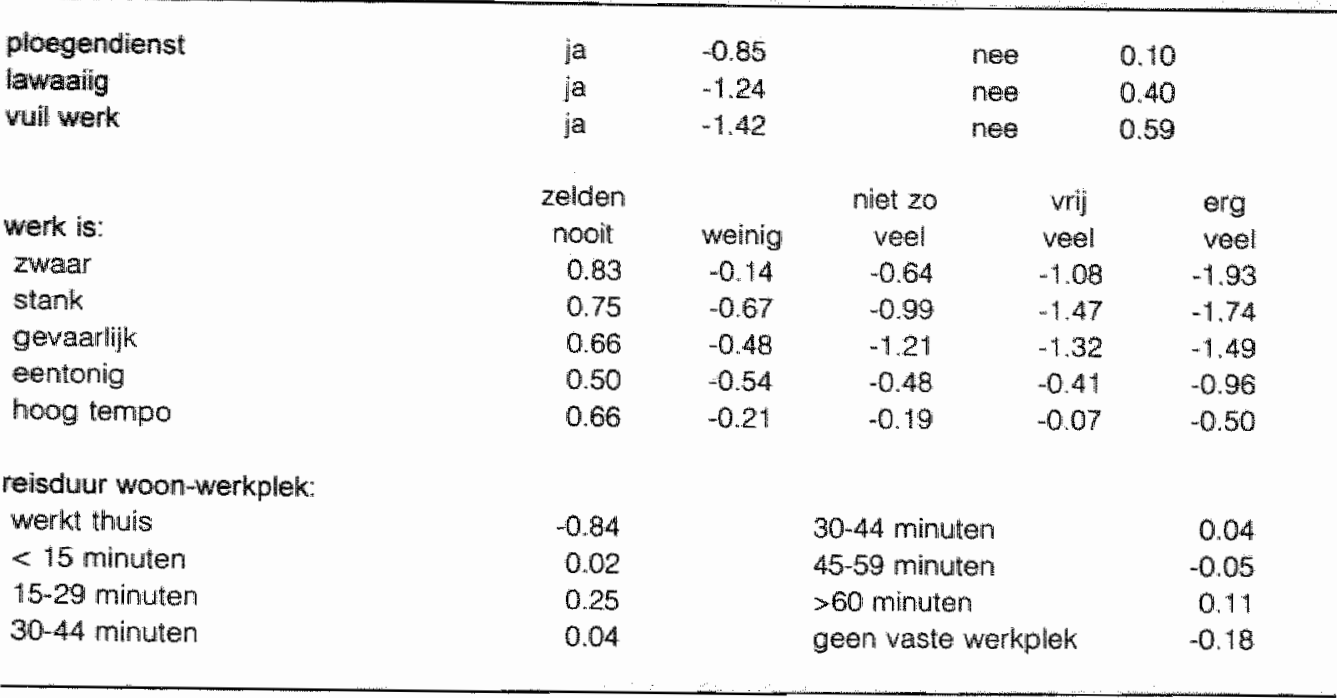

Om de antwoordcategorieën van het CBS-survey in 1980 vergelijkbaar te maken met die in de overige surveys, zijn in Tabel 5 de antwoordcategorieën met een score hoger dan én samengevoegd en ondergebracht in de categorie 'erg veel' en is deze categorie gelijkgesteld aan de antwoordcategorie 'ja, vaak' uit het 1980 survey van het CBS. Met name bil zwaar werk en hoog tempo wijken de percentages duidelijk af, maar bij de overige vragen zijn de verschillen tussen de surveys gering. Indien de categorieên 'ja vaak' en 'ja, soms' op de vraag naar zwaar werk ook worden samengevoegd, is het percentage in 1980 beter vergelijkbaar met die in de overige bestanden ( 25.9 vs $19.9-23.2$ ).

Op basis van de categoriescores uit het survey 1983 is met behulp van deze hercoderingen de kwaliteit van de werksituatie bepaald als de som van de scores op de gebruikte antwoordcategorieën (Tabel XI).

Tabel XI Werkomstandigheden van hoofden van huishoudens (\%) naar bestand.

\begin{tabular}{|c|c|c|c|c|c|c|c|}
\hline \multirow[b]{2}{*}{ BESTAND: } & \multicolumn{5}{|c|}{ SURVEY } & \multicolumn{2}{|l|}{ PANELL } \\
\hline & 1974 & 1977 & $\begin{array}{l}1980 \\
\text { CBS }\end{array}$ & $\begin{array}{l}1980 \\
\text { SCP }\end{array}$ & 1983 & 1981 & 1983 \\
\hline $\begin{array}{l}\text { Werkomstan } \\
\text { zeer slecht }\end{array}$ & & .7 & .0 & .2 & 4 & & \\
\hline slecht & & 4.8 & 3.8 & 4.4 & 4.8 & & \\
\hline gemiddeld & 20.8 & 6.1 & 5.9 & 5.2 & 5.5 & & \\
\hline goed & & 7.2 & 7.2 & 6.0 & 6.4 & & \\
\hline
\end{tabular}

\subsubsection{Bezit}

In de surveys is gevraagd naar het bezit van roerende en onroerende goederen. Verondersteld werd dat in deze lijst een onderscheid zou kunnen worden aangebracht tussen waardevaste 
bezittingen, zoals een huis of boot, duurzame huishoudelije consumptiegoederen (vaatwasser, wasmachine, -droger of diepwriezers) en duurzame consumptiegoederen voor de vrije tijd (foroen filmapparatuur, piano of vieugel e.d.) (Tabel 8).

De verschillende apparaten hebben op zich zelf genomen weinig met elkaar te maken: het bezit van een piano impliceert niet dat men ook een filmtoestel heeft en evenmin impliceent het bezit van een wasmachine de aanwezigheid van een diepvriezer. Wel veronderstelt het bezit van een wasdroger de aanwezigheid van een wasmachine en is het waarschijnlijk dat in huishoudens. met een vaatwasser ook andere huishoudelijke apparatuur aanwezig is. Het bezit van dure consumptiegoederen maakt de aanwezigheid van andere, wat minder kostbare goederen waarschijnijk. Daardoor zegt de aarwezigheid van kostbare, minder gangbare goederen wel lets over de aanwezigheid van meer gangbare goederen, maar woorspellen deze laatste niets over de aanwezigheid van de eerste. Een probalistisch schaalmodel a la Mokken levert de beschrijuing van zo'n model.

Worden de bezittingen volgens dit model beschreven, dan zijn er twee zwakke maar goed interpreteerbare schalen (Tabel XII). De eerste schaal indiceent de aanwezigheid van in 1983 als luxe te omschrijven goederen: auto, diepvriezer, wasdroger, vaatwasmachine en tweede huis

Tabel XII Percentage hoofden van huishouden naar het bezit van duurzame consumptiegoederen woor het huishouden en voor de vrije tijd in de periode 1974-1983

SUAVEY

BESTAND: $\quad 1974 \quad 1977 \begin{array}{llll}1980 & 1980 & 1983 \\ & & \text { CBS } & \text { SCP }\end{array}$

SUAVEY

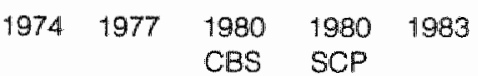

Vrije tijd:

$\begin{array}{cccccccccccc}0 & 23.9 & 22.4 & 27.8 & 27.7 & 10.4 & 0 & 33.6 & 18.5 & 97.4 & 19.2 & 9.3 \\ 1 & 48.5 & 38.9 & 52.4 & 51.6 & 30.9 & 1 & 50.5 & 26.5 & 2.6 & 23.8 & 22.8 \\ 2 & 21.7 & 28.7 & 14.9 & 15.9 & 40.6 & 2 & 15.1 & 38.2 & & 37.0 & 45.0\end{array}$

$(H=.33 ;$ who $=44)$. De tweede schaal indiceent het bezit van duurzame gebruiksvoorwerpen voor de liefhebberij of de vrije tij: elektrische boor, elektrische naaimachine, diaprojector, caravan of vouwwagen en motor of scooter $(H=.35$; tho=.46). De overige bezittingen kunnen op geen enkele wijze in zinvolle schalen worden gemodelleerd en blijven daarom in de verdere analyses buiten beschouwing.

\subsection{Indicatoren voor status}

\subsubsection{Geloofsovertuging en politieke woorkeur}

Hoewel religieuze overtuiging en politieke woorkeur samenhang vertonen door hun gemeenschappelijke basis in waardenorièntatie, is niet gepoogd beidle tot én index samen te voegen. Door de ontzuiling zou zulk een index maar een klein deel van de gemeenschappelijke waarden tot uitdrukking brengen, waardoor deze minder pregnante informatie zou geven dan de afzonderlijke kenmerken.

Per onderzoek fluctueren de percentages on- en buitenkerkelijken aanzienlijk (28\%-41\%: Tabel 2). De percentages katholieken en protestanten wijken niet sterk af van de landelijke cijfers (CBS
1990). 
De fluctuatie in politieke voorkeuren wordt weerspiegeld in de wisselende uitkomsten van de surveys. Vanwege de geringe voorkeur in de bewolking voor klein links (PPR, PSP, EVP, CPN: $3,5-6,5 \%$ ), rechts confessionelen (SGP, GPV, RPF, RKPN: $3.2 \%-6.7 \%$ (Tabel2) en klein rechts (CD. Boerenpartij, DS 70, Middenstandspartij, Democratisch Midden: $0.2 \%-1 \%$ (Tabel 2)) en de overeenkomsten in gedachtengoed, zijn deze partijen volgens bovenstaande indeling samengevoegd. Omdat de voorkeur vaor D'66 (1 - 13\%) tussen de verschillende survey-jaren sterk fluctueerde, is deze partij als aparte categorie opgenomen. Het aantal mensen zonder politieke voorkeur varieert zeer sterk tussen de onderscheiden steekproeven (2.5\%-22.1\% (Tabel 2)) (CBS 1990).

\subsubsection{Vrije tijdsbesteding}

In de onderscheiden surveys is telkens gevraagd naar de activiteiten, die in de vrije tijd worden uiltgevoerd. Everwel varieert zowel de aard van de activiteiten waarnaar wordt gevraagd, alsook de differentiatie in antwoordcategorieën. In het survey van het CBS uit 1980 is er in het geheel niet naar gevraagd (maar wel in het deel dat onder verantwoordelijkheid van het Sociaal Cultureel Planbureau is uitgevoerd). In 1977 is woor sommige activiteiten de frequentie per week en voor andere de frequentie per maand gevraagd. In de overige surveys is telkens gewraagd naar de trits "zelden of nooit', 'ja, soms' en 'ja, vaak".

Om de activiteiten zo veel mogelijk vergellikbaar te maken ziin de zeer gespecificeerde activiteiten uit 1977 samengevoegd, zodat ze naar inhoud vergelikbaar waren met de activiteiten-categorieèn zoals gebruikt in het survey 1983. Bovendien zijn de antwoordcategorieèn uit hel survey van 1977 zodlanig gehercodeerd dat zij qua invulling zo veel mogelijk overeenkwamen met de antwoordpercentages in de overige jaren. Bij twijfel is ook nog gekeken naar het verschil in schaliwaarden in 1977 en 1983. Deze wat pragmatische oplossing leek het meest adequaat om to bepalen wat 'veel' en 'soms' voor de onderscheiden activiteiten unhouden. Deze handelwijze bleek overigens geen belangrijke verstoringen te geven., De beschrijving met behulp van de schaalwaarden van de PCA volgens PRINCALS van het survey uit 1983 en die op basis van deze analyse met de oorspronkelijke coderingen wit 1977 verschillen nauwelijks van elkaar ( $r=.99$; Afbeelding 4).

De mate waarin men aan de onderscheiden activiteiten deelneemt, staat vermeld in Tabel3. Uit deze gegevens blijkt dat over de gehele periode meer dan drie kwart van de Nederiandse hoofden van huishoudens regelmatig in de vrije tijd leest, circa $60 \%$ regelmatig naar de TV kijkt en de helft geregeld naar de radio luistert. Actievere vormen van vrije-tijdsbesteding wordt door minder dan de helft van de hoofden van huishoudens uitgevoerd. Zwemmen, sporten, fietsen, er op uit trekken in de natuur en 'doe het zelven' zijn daarvan vaak genoemde activiteiten (16-42\%). Leefstijl wordt, voor zover het de vrije tijd aangaat, vanzelfsprekend niet met slechts een activiteit gemeten. Bij een still van leven hoort een zekere consistentie in gedragingen waardoor ze voorspelbaar en belarugrijker nog, voor anderen herkenbaar worden. Dit veronderstelt een duidelijke samenhang tussen onderscheiden categorieën gedragingen. Bovendien kan worden verondersteld dat in de keuze van activiteiten leeftijd en gezinssituatie worden weersplegeld: ouders en grootouders zullen nu eenmaal eerder met kinderen of kleinkinderen een attractiepark bezoeken dan mensen zonder kinderen, die gemakkelijker een cafe, museum of theater kunnen bezoeken of uit winkelen kunnen gaan. Disco's en bejaardensociëteiten recruteren hun publiek eveneens wit verschillende leeftijdscategorieën.

Door de grote verscheidenheid aan activiteiten, de grote verschillen in frequentie van deelname aan deze activiteiten en de vele toevallige factoren, die het uitvoeren van activiteiten in de vrije tijd bevorderen of juist in de weg staan, is het voorshands niet duidelijk of er wel enige 
Afbeelding 4

De beschrijuing van de activiteiten in de vije tijd van niet en wel gehercodearde vragen uit hel survey 1977

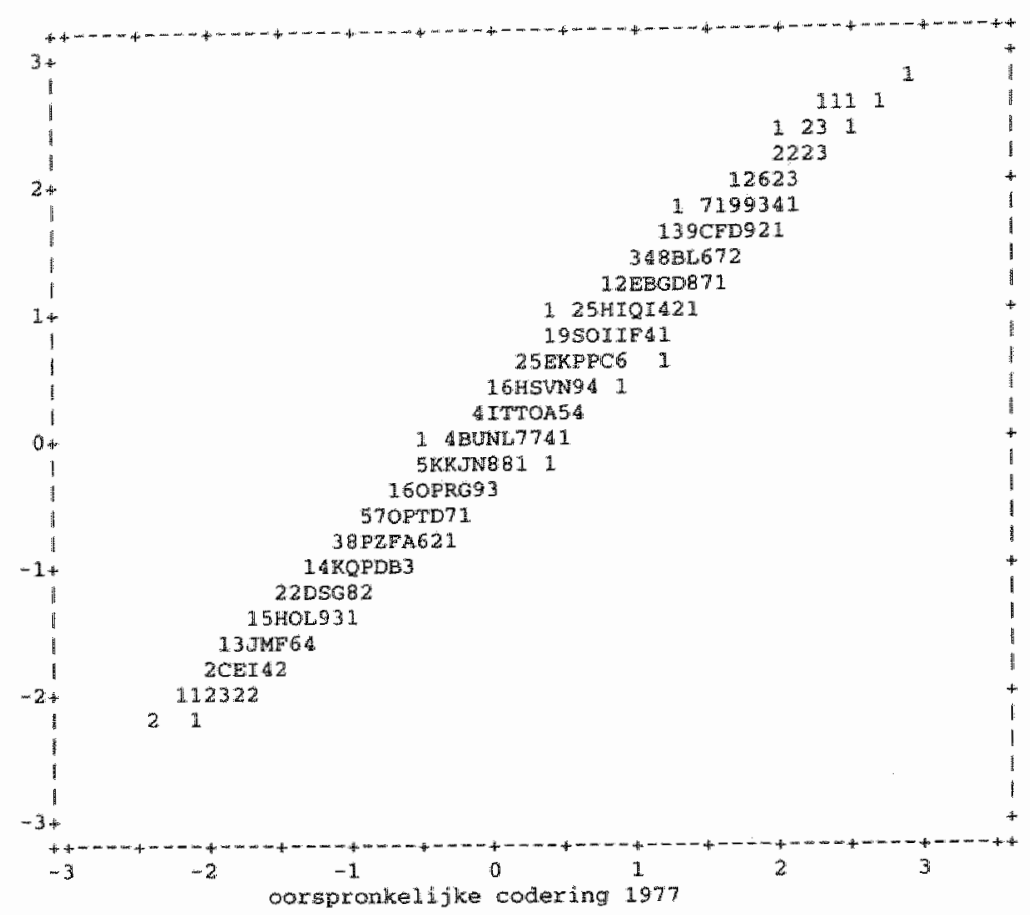

systematische ordening in het materiaal is te maken.

Bij PCA volgens PRINCALS blijkt dat éen dimensie of component vrijwel alle variatie verklaart. Deze component onderscheidt hoofden van huishoudens die geen van de gevraagde activiteiten in hun vrije tijd uitvoeren van hen die regelmatig wandelen, fietsen er in de natuur op uit trekken en lezen. Uit de discriminatiemaat en de schaalwaarden op deze component blikt bovendien. dat regelmatig bezoek aan bloscoop, recreatiepark, strand, museum of theater samengaan en dat zij die deze activiteiten uitvoeren waarschijnijk ook regelmatig gaan zwemmen, dansen, sporten en actief een hobby beoefenen. Daamaast wordt nog onderscheid gemaakt tussen sport- (sport; cafe) en cultuuminnaars (concert-, museumbezoek "zelf musiceren of fotograferen). Echter, indien alle activiteiten voor de PCA worden gebruikt. is dit onderscheid zo zwak, dat dit beter op basis van de genoemde activiteiten afzonderlijk kan worden gemaakt.

Bij analyse van deze activiteiten volgens hel schaalmodel van Mokken, blijken lezen, bibliotheek-, museum-, monumenten-film-en concertbezoek alsmede het maken van muziek of het beoetenen vam een hobby samen een zwakke schaail te vormen $(H=0.30$; rho=0.60), die kan worden opgevat als een preferentie voor culturele activiteiten (TabelXII). Het zelf beoefenen van lichamellike sporten, het bezoek aan openlucht-accommodaties, sporthallen en sportwedstrijden vormen een lets sterkere schaal, die als sportieve oriëntatie kan worden benoemd $(H=0.46$; rho $=0.78$; Tabel $X I V)$. Deze verschillende voorkeuren sluiten elkaar niet uit, er zijn cultuurminnaars die graag het café of het sportveld bezoeken.

Met uitzondering van die in het survey 1977, geven de MOKKEN-schalen voor culturele en sportieve orientatie, eenzelfde beeld te zien. In de tien jaar die de surveys bestrijken, zijn de Nederlandse 
hoofden van huishoudens actiever geworden en in hun vrije tijd meer aan sportieve en culturele activiteiten gaan doen (Tabel XII;: Tabel XIV).

\subsubsection{Leefwize: roken en alcoholgebruik}

Met betrekking tot het roken is een indeling gemaakt in mensen die wel en die niet roken. Het is zowel in de surveys als het Panetonderzoek mogelijk de hoeveeheid gerookte tabak te benaderen door deze in grammen per week uit te drukken. De maat is echter niet erg betrouwbear, te meer niet orndat in de surveys naar de gemiddelde consumptie per dag is gevraagd (van Feak, 1983). Bij schatting van de consumptie van rookwaren blijkt deze zeer ongelijk te zijn verdeeld in de bevolking. Gemiddeld wordt er 110 gram tabak per week geconsumeerd. Evenwel $12 \%$ rookt per week veel meer dan het dubbele van deze hoeveelheid. De praktische consequentie van deze scheve verdeling betekent, dat indien roken op de internationaal geaccepteerde wilize wordt geindiceerd door onderscheid te maken tusisen mensen die wel en niet roken, een kleine groep zware rokers de resultaten voor de gehele categorie van rokers kan vertekenen. Vanwege het grote aandeel van sigaretten en shag ( $90 \%$ van de rokers) is de keuze voor bepaalde rookwaar als aspect van de leefstijl niet verder uitgewerkt (Tabel XV).

Tabel XIII Mate van deelname aan culturele activiteiten (\%) in de vrije tijd

Cultudur: $\quad$ SURVEY

\begin{tabular}{rrrr}
\cline { 2 - 3 } \\
$1974 \quad 1977$ & 1980 & 1983 \\
\hline
\end{tabular}

\section{0}

1

2

3

4

5
5.6

2.4

4.0

2.9

41.2

22.0

21.1

37.1

15.9

30.7

10.6

4.1

5.4
31.2

21.7

17.8

31.3

21.6

19.7

15.7

3.6

8.5

8.7

$\mathrm{H}=30 ; \mathrm{AHO}=.60$

Tabel XIV Mate van deelname aan sportiewe activiteiten (\%) in de vrije tijd

\begin{tabular}{lrrrr} 
Sport: & \multicolumn{4}{l}{ SURVEr } \\
\cline { 2 - 5 } & 1974 & 1977 & 1980 & 1983 \\
\hline \multirow{2}{*}{1} & 43.1 & 46.3 & 46.4 & 41.8 \\
1 & 22.3 & 19.4 & 22.0 & 21.2 \\
2 & 17.5 & 14.6 & 16.5 & 21.6 \\
3 & 12.4 & 13.6 & 15.1 & 15.4 \\
4 & 4.7 & 5.9 & & \\
& & & $H=.46 ; \mathrm{RHO}=.78$
\end{tabular}

Sinds 1980 is alcoholgebruik in de surveys opgenomen. Gevraagd is of men wel eens alcohol drinkt en indien dit het geval is, hoeveel er wekelijkse wordt gedronken. In het survey 4983 is naar de gemiddelde dagelijkse consumptie gevraagd. In het Panelonderzoek is de respondenten gevraagd naar de consumptie op de dagen van de afgelopen week. Deze laatste methode lewert een betrouwbaarder schatting op dan de eerste "Lemmens: 1990).

Voor de vergelijkbaarheid van de verschillende bestanden woidt onderscheid gemaakt tussen mensen die geen alcohol drinken (ongeveer $20 \%$ ), lichte drinkers (0 tot 20 glazen per in de afgelopen week; ongeveer tweederde van de hoofden van huishoudens), matige drinkers (21 . 35 glazen per week; ongeveer $8 \%$ ) en stevige drinkers ( $>35$ glazen per week; rond de $3 \%$ ) (Tabel $x$ ). In het Panelonderzoek kan, ter bepaling van de leefwijze, nog onderscheid worden gemaakt naar het soont drank dat men gewoon isi te drinken. 
Tabel XV Percentage hoofden wan huishoudens en hun mate van alcoholgebruik en roken in de periode $1974-1983$

\begin{tabular}{|c|c|c|c|c|c|c|c|}
\hline \multirow[b]{2}{*}{ BESTANO: } & \multicolumn{5}{|c|}{ SURVEY } & \multicolumn{2}{|l|}{ PANEL } \\
\hline & 1974 & 1977 & $\begin{array}{l}1980 \\
\text { CBS }\end{array}$ & $\begin{array}{l}1980 \\
\text { SCP }\end{array}$ & 1983 & 1981 & 1983 \\
\hline \multicolumn{8}{|l|}{ drinken: } \\
\hline drinikt geen alcohol & & & 20.2 & 16.8 & 17.7 & 16.4 & 15.0 \\
\hline lichte drinker (0-21 glazen) & & & 70.7 & 74.3 & 66.3 & 65.1 & 69.3 \\
\hline matige drinker (22-35 glazen & & & 7.2 & 7.1 & 8.6 & 13.0 & 122 \\
\hline stevige drinker (>35 glazen) & & & 1.9 & 1.7 & 3.4 & 5.4 & 3.4 \\
\hline $\begin{array}{l}\text { roken: } \\
\text { rookt niet }\end{array}$ & & & 46.0 & 45.6 & 49.3 & $43 . \#$ & 42.3 \\
\hline
\end{tabular}

Samenwattend kan worden gesteld dat status, zoals deze zich uit in leefstijl in dit onderzoek is geindiceerd met behulp var politieke voorkeur, religieuze overtuiging en het wel of niet in de vrije tijd er op uit trekken, en naar de woorkeur voor activiteiten in de sportieve of culturele sfeer. De leefwijze is geindiceerd met de riskante gewoonten roken en alcoholgebruik, die zijn gemeten door onderscheid te maken tussen respectievelijk rokers en niet-rokers en mensen die geen alcohol drinken, lichte en matige drinkers en stevige drinkers.

\subsection{Indicatoren voor burgerschap}

Burgerschap wordt geïndiceerd door burgerlijke staat, het hebben van kinderen, door lidmaatschap van verenigingen, het doen van vrijwilligerswerk en het gebruik van maatschappelijke voorzieningen.

\subsubsection{Burgerlike staat}

Ruim drie kwart van de hoofden van huishoudens is gehuwd of woont samen (Tabel 9). De toename van het aantal echtscheidingen na 1973 is duidelijk te traceren. Het aantal verweduwden onder de hoofden vari huishoudens loopt per bestand sterk uiteen (van $4 \%$ in de surveys van 1974 en 1983 tot $13 \%$ in het survey van 1977). Ook het aantal alleenstaanden varieert sterk (van $1 \%$ in het survey 1974 tot 12 a $13 \%$ in de surveys uit 1980). Hoewal de antwoordcategorieên op de vraag naar burgerlijke status tussen de surveys en het panel verschillen, zijn de variaties binnen de surveys uit de achtereenwolgende jaren van het Leefsituatieonderzoek en in de Panelsurveys groter dan tussen beide onderzoeken. Een adequate verklaring van de verschillen tussen de steekproeven is derhalve niet te geven. Omdat niet-thuiswonende kinderen niet in de surveybestanden konden worden achterhaald. is deze indicator niet gebruikt.

\section{4:4.2 Lidmaatschap van en activiteiten in verenigingen}

Een belangrijk burgerrecht is dat van vrije associatie. Het lid zijn van verenigingen en organisaties is daarmee te zien als een kenmerk van burgerschap. Bovendien wordt door actieve deelname aan het verenigingsleven het burgerschap ook daadwerkelijk uitgleoefend, komt men met anderen in aanraking en wordt men opgenomen in de maatschappij (Turner 1988). 
Hoewel veel mensen wel van een of andere vereniging lid zijn, is het beeld tamellik heterogeen. Ruim eenderde deel is lid wan een vakbond of werkgeversvereniging en een kwart lid van een sportclub of van een bibliotheek (Tabel 10). Het lid zijn van een vereniging zegt weinig over het lidmaatschap van andere verenigingen. Deze heterogeniteit is ook af te lezen uit de lage onderlinge samenhang tussen de verenigingstidmaatschappen (correlathes alle $<.16$ ).

Bij toepassing van PCA komen er drie componenten naar voren, die tezamen iets minder dan eenderde van de variatie in hel materiaal verklaren (31\%). Deze componenten zijn te benoemen als maatschappij (kerk, politiek, valkbond, bibliotheek), cultuurparticipatie (toneel, muziek, vrouwen-en zangvereniging) en collectieve vrije tijdsbesteding (sport, jeugd, overige verenigingen) (Tabel XVI). Deze zullen alle drie in de analyses wordien gebruikt, omdat ziil verschillende maatschappelijke sectoren aangeven waarop burgers hun rechten kunnen uitoefenen.
Tabel XVI Principale Componenten van lidmaatschappen voor het survey 1983

Principale Componenten

i II III $n^{2}$

\section{Lid van:}

godisdienstige vereniging

.65

politieke partij

.63

45

werknemers- werkgevers-

vereniging

.4

29

bibliatheerk

.39

24

zang , muziek- of

toneelvereniging

vrouwenvereniging

$.37 \quad .40$

.34

.52

.35

andere culturele vereniging

sportclub

64.41

owerige verenigingen

$.50 \quad .20$

jeugdvereniging

$.37 \quad .32$

hobbyclubs

EIGENMAARDE. $\quad 1.4 \quad 1.2 \quad 1.1$

$\begin{array}{lllll}\% \text { NEFHEL. VARIANTIE } & 11.7 & 10.0 & 9.5 & 31.1\end{array}$

\subsubsection{Maatschappelijke activiteiten}

lets meer dan eén derde van alle onderzochte hoofden van huishoudens is lid van een vakbond en $2 / 9$ van hen is daarin actief. Ruim een kwart is lid van een sportvereniging en twee derde van hen sport ook daadwerkelijk of besteedt zijn vrije tijd aan het organiseren van sportevenementen. Ruim tien procent van alle hoofden van huishoudens beoefent een hobby, maar niet allen zijn daarvoor lid van een vereniging. Tien procent van de ondervraagden gaat regelmatig naar de kerk en de helft van hen bekleedt een functie in de kerk. Vrijwel allen die lid zijn van ben zang-. muziek- of toneelvereniging zijn daarin ook actief $(6 \%)$ (Tabel 11). Van de hootden van huishoudens die lid zijn van een politieke partij noemt zich slechts éen derde actief lid. Nog geen procent is actief in de vrouwenbeweging. Een klein aantal mensen doet vijwilligerswerk op school ( $\pm 5 \%$ ) of in de hulpverlening aan jeugdigen of volwassenen Tabel 11).

De principale componentenanalyse geeft de domeinen van de verenigingen of van de gebieden waarop mensen maatschappelijk actief zijn goed weer. De activiteiten leverden drie goed interpreteerbare componenten $o p$, die tezamen $42 \%$ van de variatie in het materiaal bepalen (TabelXVII). De eerste kan worden benoemd als vrijwilligerswerk (kinderopvang, hulpwerlening, maatschappelijke dienstverlening, jeugdwerk, schoolbestuur, vrouwenbeweging), de tweede als individuele belangenbehartiging ('sport, vakbond, hobby, hulp op school) en de derde als cultuur participatie (kerkewerk, politiek, muziek, zang en overig culturele activiteiten). Zoals bil hel lidmaalschap, zullen ook deze drie componenten alle worden gebruikt bij verdere analyse orndat 
ook zil verschillende sectoren aangeven, waarop de burger zijn betrokkenheid bil de samenleving kan manifesteren.

\subsubsection{Gebruik van voorzieningen}

In de discussie over burgerschap staat heden ten dage de vraag centraal of mensen hun burgerschap verliezen door hun rechten op de staat ook daadwerkelijk op te eisen. Zo lijkt het erop dat door thet genieten van een uitkering men in meer dan een opzicht zijn of haar burgerrechten verliest. Door de regelingen waaraan men zich dient te onderwerpen om voor de uitkening waarop men als burger recht heeft, in aanmerking te komen raakt men zijn autonomie, alsook zijn recht op privacy kwilt (verplichting informatie te geven over de persoonlijke situatie, voordeurdelersregeling, verplichting werk te zoeken, zich te laten keuren etc.). In meterieel opzicht impliceert een minimuminkomen een risico op sociale isolatie omdat men zich de kosten van het sociale werkeer (waaronder lidmaatschappen van verenigingen) niet meer kan permitteren. Op deze wijze zouden deze voorzleningen een anderscheid tussen eerste en tweederangs burgers kunnen creeren (Tumer 1988; 1990).
Tabel XVII Principale Componenten wan vrijwlligerswerk voor het survey 1983

Principale Componenten

\begin{tabular}{lllll} 
& $\|\quad\| \quad \mathrm{h}^{2}$ \\
\hline
\end{tabular}

\section{Actief in:}

kinderopvang

andere hulpverlening

.86

.75

overige maatschappelijke

dienstverlening

.44

vrouwenvereniging

.68

.52

schoolbestuur

.58

.50

jeugdwerk

.42

sport

beroepsorganisalie

hobby

hulp op school

actiegroepen

anders cultureel

godsdienst

politiek

zang/muziek/toneel

.60

.74

.36

.57

.40

.54

.51

.35

.41

\section{EIGENWAAARDE}

$3.50 \quad 1.43 \quad 1.40$

\% VERKLAARDE VARIANTIE

Over het algemeen maken slechts zeer weinig hoofden van huishoudens gebruik van de verschillende voorzieningen. De belangrijksts zijn telkens de wijkverpleging, de gezinszorg en de gemeentelijke sociale diensten (Tabel 12). Evenmin als voor verenigingslidmaatschappen of wijwilligersactiviteiten, is voor de voorzieningen interne consistentie te verwachten, ook al verwijzen ze alle naar burgerschap. Wel lijkt het waarschijnlijk dat mensen die psychiatrische zorg ontvangen ook met ander vormen van hulpverlening in aanraking komen en dat mensen die gebruik maken van de wijkverpleging ook eerder in contact komen met de gezinszorg of kraamhulp dan met ambulant psychiatrische zorg. De uitkomst van de principale componentenanalyse geeft drie domeinen van voorzieningen aan; waar mensen valn gebruik maken en die tezamen $30 \%$ van de variatie in het materiaal verklaren (Tabel XVIII): een sociaalmedische (kruisvereniging, kraamzorg, wijkverpleging, gezinszorg en consultatiebureaux voor geboorteregeling), een maatschappelijke (jac, bureaux voor levens en gezinsvragen, medisch opvoedkundige bureaus, maatschappelijk werk, sociale diensten) en een component die hulpverlening voor problemen op het persoonlikk vlak beschrift (SPD, telefonische hulpdienst, medische psychotherapie, wetswinkel en burgerraadslieden). Deze drie componenten zullen alle worden gebruikt bij de beschrijving van het gebruik van voorzieningen omdat zij duidelijk onderscheiden probleemgebieden aangeven. 
Tabel XVIII Principale Componenten in het gebruik van voorzieningen in het survey 1983

\begin{tabular}{|c|c|c|c|c|}
\hline & \multicolumn{4}{|c|}{ Principale Componenten } \\
\hline & 1 & !1 & $\| 11$ & $h^{2}$ \\
\hline Voorziening: & & & & \\
\hline Kruisvereniging & .80 & & & .64 \\
\hline Kraamhulp & .79 & & & .63 \\
\hline Wikverpleging & .60 & & & .36 \\
\hline Gezinsverzorging & .36 & & & .25 \\
\hline $\begin{array}{l}\text { Centrum woor } \\
\text { geboorteregeling }\end{array}$ & .36 & & & .13 \\
\hline Jongeren Advies Centrum & & .67 & & .46 \\
\hline Bureau Levens- \& Gezinsvragen & & .62 & & .39 \\
\hline Medisch Opvoedkundig Bureau & & .60 & & .37 \\
\hline Algemeen Maatschappelijk Werk & & .51 & & .29 \\
\hline Gemeentelijke Sociale Dienst & & .37 & & .21 \\
\hline Socilaal Psychiatrische Dienst & & & .67 & .47 \\
\hline Telefonische hulpdienst & & & .57 & .33 \\
\hline Medische psychotherapie & & & .50 & .25 \\
\hline Wetswinkel & & & .47 & .24 \\
\hline Burgerraadslieden & & & .41 & .28 \\
\hline Bedrijfsmaatschappelijk werk & & & & .12 \\
\hline Dienstencentrum voor bejaarden & & & & .01 \\
\hline Consultatiebureau Alcohol \& Drugs & & & & .01 \\
\hline EIGENWAARDE & 2.22 & 1.87 & 1.34 & \\
\hline$\%$ VERKLL. VARIANTIE & 23.4 & 9.6 & 9.4 & 30.2 \\
\hline
\end{tabular}


Schema B Overzicht wan de gebruikte begrippen, hun indicering en onderlinge relaties

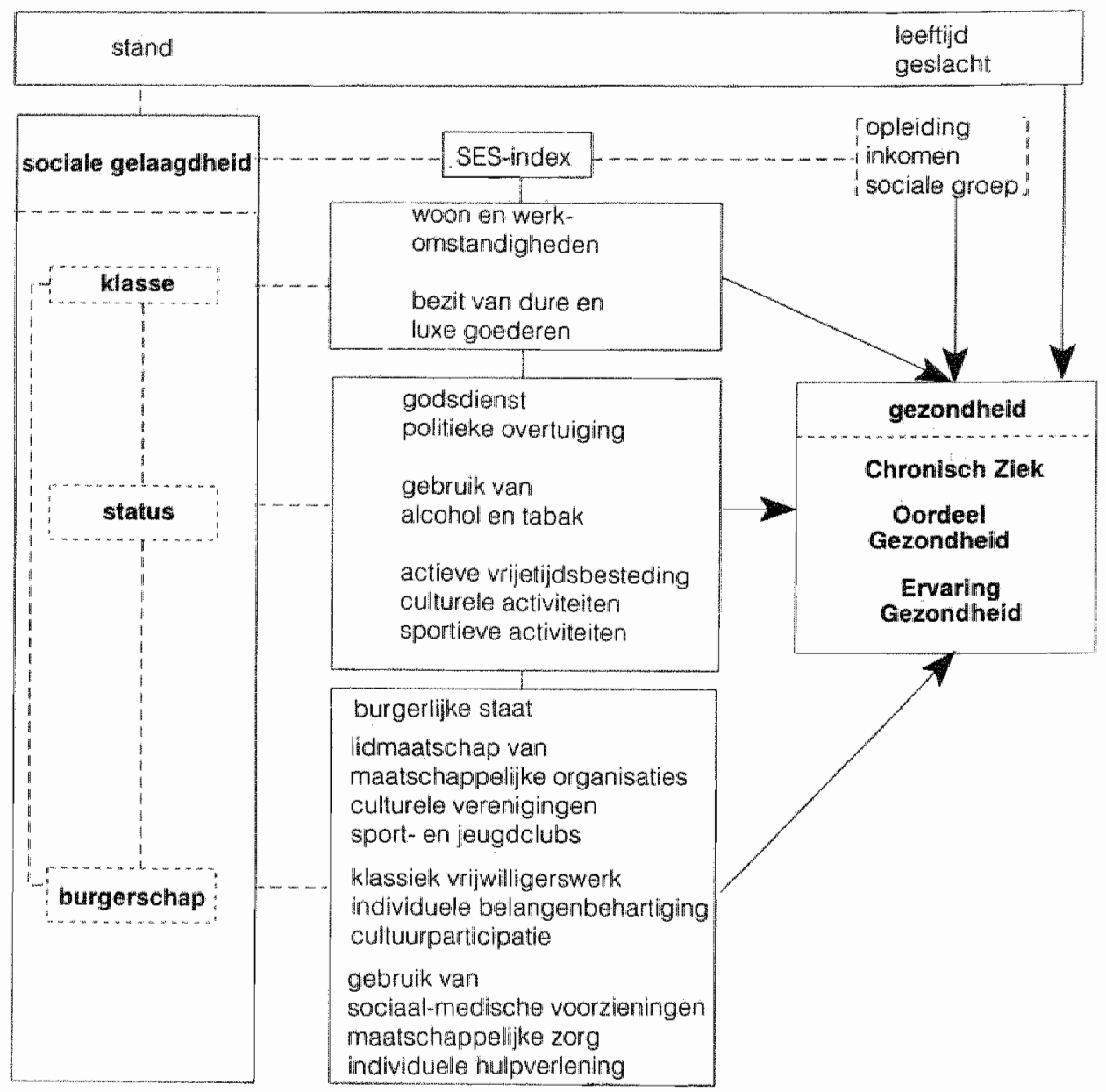


In dit hoofdstuk wordt eerst de verdeling van chronische ziekten en van subjectief ervaren gezondheid over de sociale strata beschreven. Daarna worden de in hoofdstuk 2 geformuleerde onderstellingen onderzocht, waarbij telkens eerst de aanwezigheid van chronische aandoeningen, dan de subjectieve gezondheid, tot uiting komend in het oordeel over de eigen gozondheid en tenslotte de ervaren gezondheidsklachten in de analyse worden betrokken.

\subsection{Sociaal-economische gezondheidsverschillen onder Nederlandse hoolden van huishoudens}

Voordat de onderstellingen van deze studie kunnen worden onderzocht, zal moeten worden vastgesteld of er inderdaad sprake is van een ongelijke verdeling van (on)gezondheid over de sociale strata. Sociaal-economische verschillen in gezondheid zoulden kunnen worden uitgedrukt in de gestandaardiseerde regressiecoëfficiënt ( $\beta$ ) van de SES-index op gezondheid, onder controle van leeftijd en geslacht. Echter, de relatie tussen SES en gezondheid is niet monotoon stijgend, de middengroepen hebben vaak een betere gezondheild dan de hoogste en laagste SES-categorieèn (Chenu 1988, Blaxter 1990. Wikinson 1986). De B-coëfficiënt zou daarom van de sociaal-economische gezondheidsverschillen een geinflateerd beeld geven.

Dit probleem wordt voorkomen door gebruik te maken van concentratie-curves, waarbij de bevalking op de SES-index wordt geordend en wordt afgezet tegen het cumulatief percentage gezonden op een willekeurige index voor gezondheid (Wagstaff, Paci, van Doorslaer, 1991). indien dit percentage in gelijke mate toeneemt met de SES-index, dan is het percentage gezonden in elke SES-categorie gelijk. In dat geval zijn er dus geen sociaal-economische gezondheidsverschillen, de cuive valt samen met de diagonaal. In het geval de proportie ongezonden in de laagste categorieën van de SES-index groter is dan in de hogere categoneên, stijgt de index voor gezondheid minder snel dan de cumulatieve SES-index; een index voor ongezondheid zou juist sneller stijgen. Zouden de socialal-economische middengroepen over een betere gezondheid beschikken dan de hoogste en laagste soclaal-economische strata dan zouden bij een gezondheidsindex laatstgenoemde categorieën onder of op de diagonaal liggen en de middengroepen respectievelijk op of boven de diagonaal.

De grootte van de sociaal-economische gezondheidsverschillen wordt aangegeven door het gebied tussen de diagonaal en de concentratie-curve en kan zowel visueel als getalsmatig worden weergegeven. Omdat deze maten niet zijn gebaseerd op onderstellingen over de verdeling van de indices voor SES en gezondheid, maar gebruik maken van de rangordening wan (steekproeven uit) de bevolking op deze indices, kunnen uiteenlopende metingen in verschillende bestanden toch goed met elkaar worden vergeleken.

In Afbeelding 5 Afbeelding 6 en Afbeelding 7 worden de concentratiecurves weergegeven voor respectievelijk het percentage chronisch zieken, het oordeel over de eigen gezondheid (OEG) en de erwaren gezondheid (VOEG) voor hoofden van huishoudens in de Nederlandse bevolking tussen 1974 en 1983, gecontroleerd voor leeftijd en geslacht. Uit de figuren is duidelijk af te lezen dat de ongelijke verdeling van gezondheid wrijwel de gehele range van de sociaal-economische index bestrijkt. Slechts in de twee hoogste decielen van de SES-index 
Afbeelding 5 Sociaat-economische ongelikheid in chronische ziekten in de periode $1974-1983$

Cumulatiel of chronisch zieken

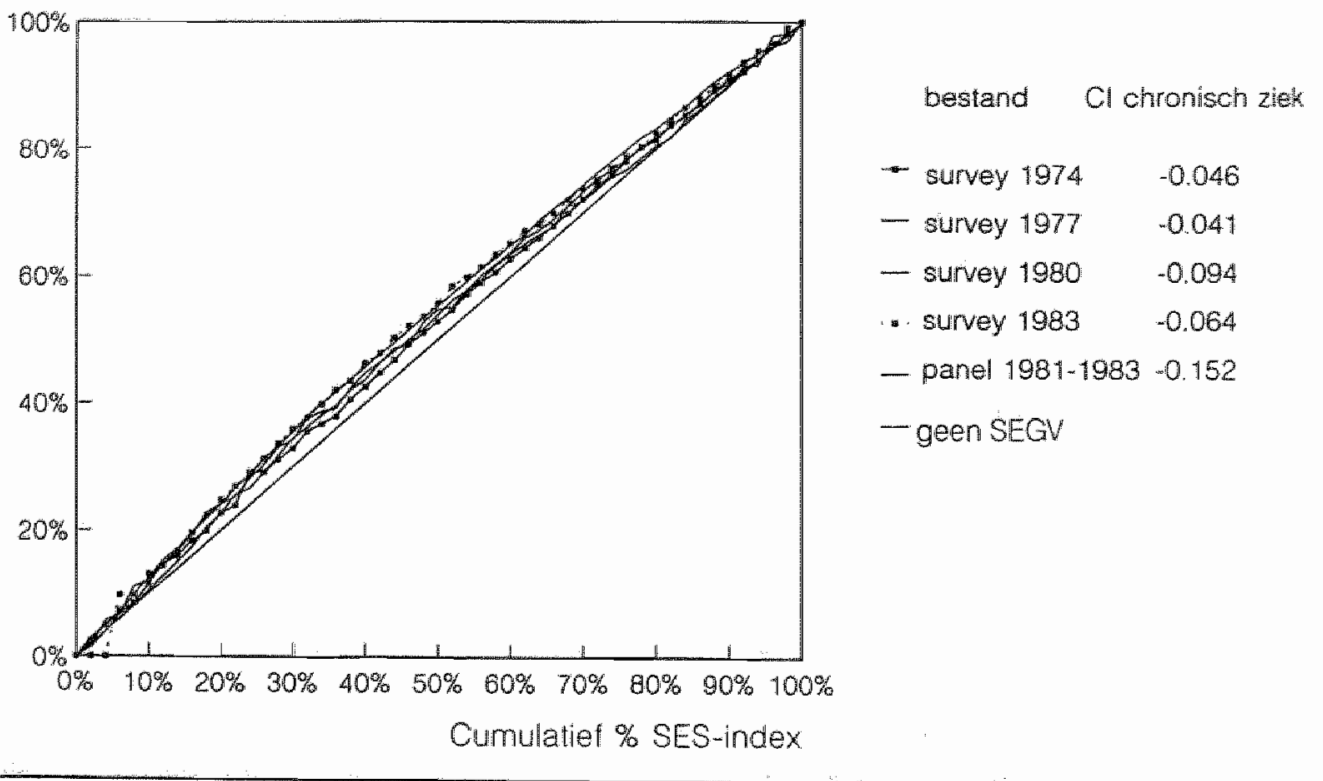

Afbeelding 6 Sociaal-economische ongelifkheid in thet oordeel over de eigen gezondheid in de periode 1974-1983

Cumulatief \% oordeel gezond (OEG)

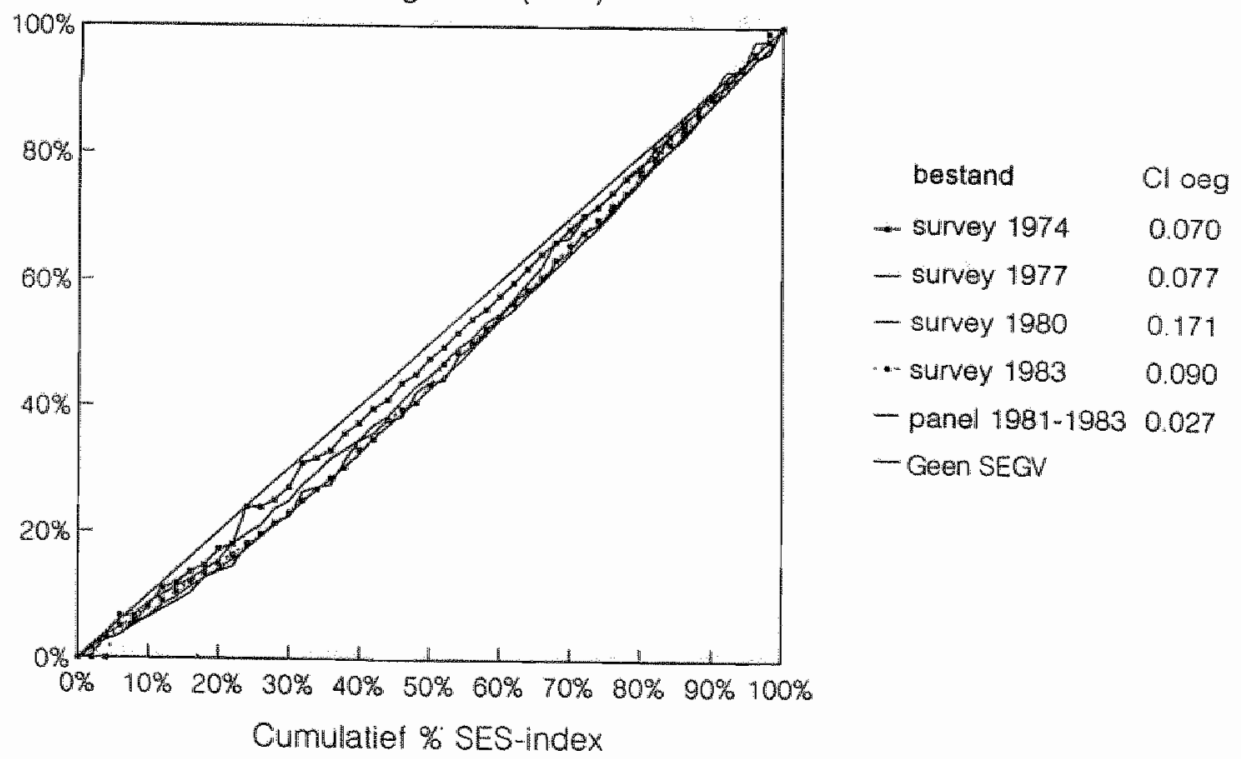


Afbeelding 7 Sociaal-economische ongelijkheid in ervaren gezondheid in de periode 1974 1983

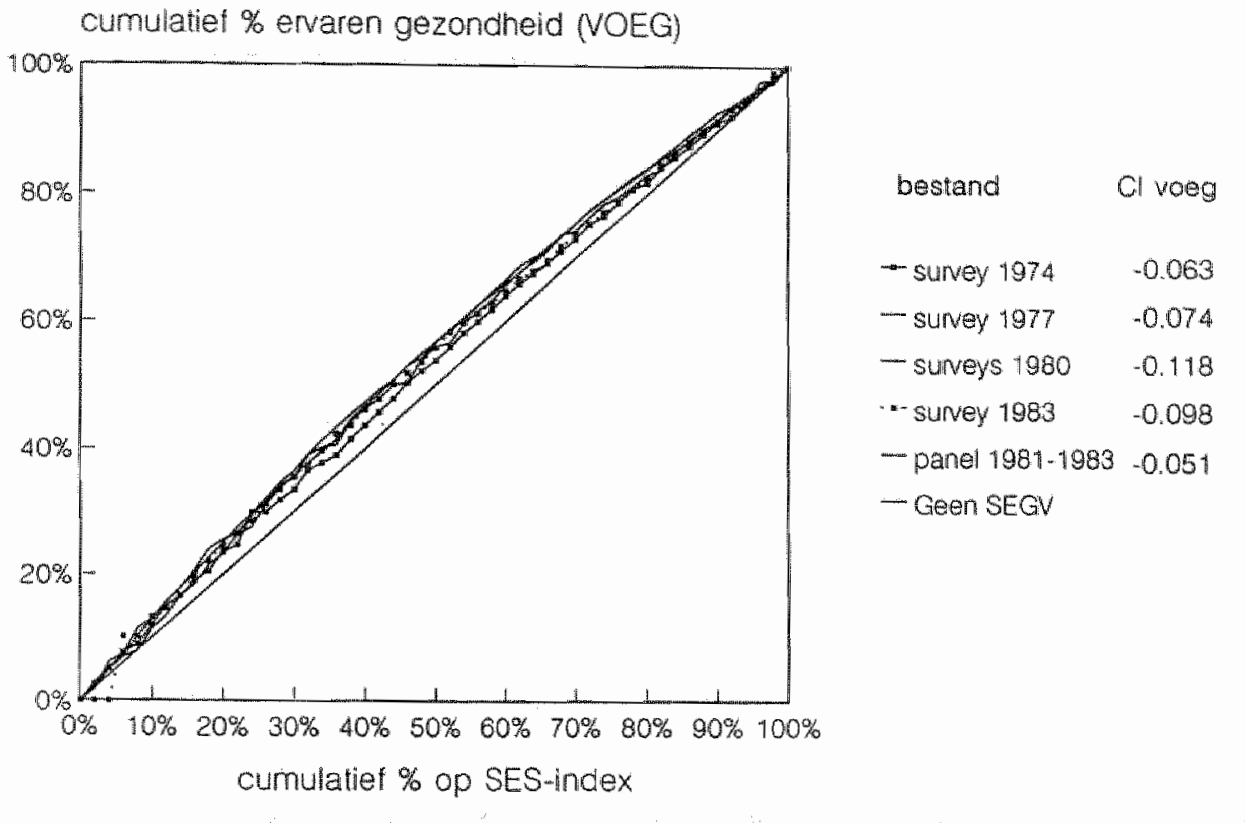

Vlakt de ongelijkheid af. Eveneens blijkt uit deze figuren dat in Nederland de ongelijke verdeling van gezondheid over de sociale lagen tussen 1974 en 1983 is toegenomen. Dit is in studies op populatie-niveau niet eerder vastgesteld.

De figuren laten echter ook zien dat, ondanks deze toename van sociaal-economische gezondheidsverschillen in de onderzochte periode, de ongelijkheid in gezondheid nog steeds niet bijzonder groot is. Dit betekent dat de variatie in gezondheid tussen de sociaal-economische lagen in verhouding tot de variatie in gezondheid binnen de sociaal-economische lagen gering is. Ook met een adequate theorie, die geldig is geindiceerd en geoperationaliseerd en waarvoor de metingen betrouwbaar en valide zijn, kan daarom slechts een klein deel van de ongelijkheid worden verklaard. Tot op heden is in elke studie naar de verklaring van individuele verschilien in gezondheid de variatie in gezondheid tussen individuen veel groter gebleken dan die naar welk sociaal of biologisch kenmerk ook (van der Zee 1982; Mootz 1987; van der Horst 1989; Grand, Grosclaude, Bocquet e.a. 1990). Het is daarom niet te verwachten dat deze studie, waarin wordt getracht op individueel niveau sociaal-economische gezondheidsverschillen te verklaren, hierop een uitzondering zal vormen.

\subsection{Sociaal-economische gezondheidsverschillen als artefact}

De eerste onderstelling van dit onderzoek betreft de mogelifkeid dat de sociaal-economische gezondheidsverschillen als artefact moeten worden beschouwd, 1.c. zijn te herleiden tot systematische verschillen in leeftijd en geslacht. Dat zou betekenen, dat de relatie tussen SES en gezondheid teweeg wordt gebracht doordat leetijd en geslacht zowel iemand's socialle status als zijn gezondheidstoestand beirvloeden. In dat geval is te verwachten dat de tweede- 
orde partiele correlaties tussen SES enerzijds en de aamwezigheid van chronische aandoeningen, alsmede de gepercipieerde en ervaren gezondheid anderzijds, zouden verdwininen wanneer voor leettijd en geslacht wordt gecontroleerd.

Dit blikkt niet het geval te zijn, de wweede-orde partiële correlaties zijn ongelijk aan nul (mediaan op -.097*, range van - $213^{* *}$ tot -.059 ). Uit regressie-vergelijkingen blijkt ook dat de SES-index onafhankelikk van leeftijo en gestacht, een belangrijke bijdrage levert aan de beschriving van verschiflen in gezondheid (Tabel $X(X)$. Onderstelling 1 wordl daarmee verworpen: sociaaleconomische gezondheidsverschillen worden niet veroorzaakt doordat leeftijd en geslacht sociale status en gezondheid beïnvloeden.

\subsection{Sociaal-economische gezondheidsverschillen als gevolg van selectie en drift}

De tweede onderstelling heeft betrekking op de processen van drift en selectie als aorzaken van sociaal-economische gezondheidsverschillen. De aanwezigheid van chronische of langdurige aandoeningen kan worden gezien als een "eindstation' van een ziekteproces. Indien mensen gevangen bijiven in een lagere status vanwege hun gezondheid (selectie) zal dat vooral gebeuren doordat zij een langdurige aandoening hebben of chronisch ziek zijn en niet omdat ze klachten hebben of omdat ze menen dat hun lichaam niet erg sterk is. Bijgevolg zou van de relaties van de SES-index met de subjectieve gezondheidsmaten na invoering van leeftijd, geslacht en de gezondheidsmaten vooral die met chronische ziekte moeten overblijven. Afglijden naar een lagere sociale laag (drift), is alleen mogelijk als gevolg van het hebben van eer langdurige aandoening; van een voorbijgaande klacht of ziekte-episode is dat effect niet goed voorstelbaar. Ook in datt geval zou de relatie van chronische ziekte met de SES. index dus meer dan die met klachten of met het oordeel over gezondheid overeind moeten blijen. Indien selectie en drift werkzaam zijn, wordt ondersteld dat in transversaal onderzoek deze processen zich viten in eem hogere prevalentie van chronisch zleken in de lagere sociale lagen. Omdat een negatief cordeel over de gezondheid of het hebben van lichamelijke klachten niet behoeft te verwijzzen naar een chronische aandoening of ziekte, maar chronische ziekte waarschijnlijk wel gepaard gaat met een negatief oordeel over de gezondheid en/of klachten. dient voor deze mogelijke verstoorders van de relatie te worden gecontroleerd. Er mag dan worden verwacht dat de (vierde-orde) partiele correlatie tussen sociale status en de aanwezig. heid van chronische aandoeningen bij controle woor leeftijd en geslacht alsook de gepercipieerde en ervaren gezondheid, significant werschilt van nul. Afbeelding 8 geeft de range wan de vierde-orde correlaties tussen alle hiervoor genoemde kenmerken.

Alleen de vierde-orde partiele-correlatie tussen de SES-index en de aanwezigheid van chronische aandoeningen verschilt niet duidelijk var nul. Onderstelling 2 wordt derhalve verworpen: sociaal-economische gezondheidsverschillen worden niet veroorzaakt doordat als regel chronisch zieken geleidelijk afglijden naar lagere socialal-economische posities of geen sociale stijgingskansen hebben.

\subsection{Verklaringsmechanismen van sociaal-economische gezondheidsverschillen}

In de derde en centrale onderstelling van dit onderzoek wordt aangenomen dat, onder controle van leeftijd en geslacht, sociaal-economische gezondheidsverschillen zijn te verklaren uit verschillen in status, klasse en burgerschap. De effecten van status, klasse en burgerschap op gezondheid zijn bepaald met een hierarchische regressieanalyse volgens de kleinste-kwadratenmethode. die werd uitgevoerd op het oordeel over de eigen gezondheid (OEG) en op de ervaren gezondheid (VOEG), waarbij eerst de variabelen leeftijd en geslacht en de SES-index werden ingevoerd. Voor de aanwezigheid wan chronische ziekten (CHRON), werden deze 
effecten onderzocht met behulp van een logistische regressie-analyse. Doordat niet woor alle indices en indicatoren in voldoende mate geldige waarden voohanden waren. wijkt het aantal personen in deze laatste analyses af van het aantal in de geselecteerde steekproet.

Tabel XIX geeft de veranderingen in verklaarde variantie weer van respectievelijk gepercipleerde gezondheid (OEG), ervaren gezondheid (VOEG) en de aanwezigheid van chronische aandoeningen (CHRON), na inwoering van achtereenvolgens klasse (leefsituatie), status (leefstijl) en burgerschap (sociale participatie), na uitschakeling van leeftijd, geslacht, SES en kenmerken van de woonplaats van de hoofden van huishoudens.

Wit de tabellen is af te lezen dat in totaal $5 \%$ tot $20 \%$ van de variantie in de onderscheiden gezondheidsindicatoren wordt verklaard. Leeftijd en geslacht leveren aan deze verkla-

ring de belangrijkste bijdrage (énderde tot meer dan driekwart; ruwe bijdragen van $2 \%$ tot $15 \%$ ) en de sociaal-economische index nog eens $5 \%$ tot $25 \%$ (ruwe bijdragen varieren van 1 tot $3 \%$ ). De bijdrage van regio (het zuiden van Nederland lijkt ongezonder dan het noorden) en umbanisatiegraad, is te verwaarlozen (ruwe bijdragen yam nog geen $1 \%$ ).

De drie veronderstelde mechanismen van het bestaan van sociaal-economische gezondheidsverschillen leveren elk een kleine, maar significante bijdrage aan het verklaren van verschillen in gezondheid. In vrijwel alle bestanden is daarin het aandeel van 'leefsituatie' (klasse) het belangrijkst (1\% tot $5 \%$ ); 'leefstijl' (status) levert een iets geringere bijdrage aan de werklaring wan de variantie ( $1 \%$ tol $4 \%$ ). 'Sociale participatie' (burgerschap) levert de geringste bijdrage levert $(0 \%$ tot $3 \%$ ). Tezamen leveren de drie mechanismen van sociaal-economische gezondheidsverschillen een ruwe bijdrage van 3 tot 9 procent verklaarde variantie, hetgeen neerkomt op een relatieve bijdrage van een kwart tol eenderde van de totaal verklaarde variantie. Omdat "leefsituatie', 'leefstijl' en 'sociale participatie' ek een eigen, onafhankelike bijdrage leveren aan de verklaring van gezondheidsverschillen onder hoofden van huishoudens, ook nadat is gecontroleerd voor de gemeenschappelijke kenmerken van deze drie mechanismen, zoals geindiceerd door de SES-index "kan hypothese 3 niet worden verworpen: Klasse, status en burgerschap zijn drie complementaire mechanismen voor de verklaring van sociaal-economische gezondheidsverschillen.

\subsection{Relaties tussen de onderscheiden mechanismen}

\subsubsection{Klasse, status, burgerschap: complementaire of concurrerende verklaringen?}

Hoewel daawoor geen specifieke onderstellingen konden worden geformuleerd, werd in hoofdstuk 2 wel rekening gehouden met de mogelijkheid dat de drie mechanismen niet onafhankelijk van elkaar werkzaam zijn. maar elkaar versterken of juist verdringen. Om deze effecten nader te onderzoeken is nagegaan hoe de som van de verklaarde variantie van de afzonderlijk in de analyse ingevoerde mechanismen zich verhoudt tot de verklaarde variantie 
Tabel $X X X$ Veranderingen in verklaarde variantie voor gepercipieerde en ervaren gezondheid bij invoering wan verschillende mechanismen woor SEGV

\begin{tabular}{|c|c|c|c|c|c|c|c|}
\hline \multirow[b]{2}{*}{ BESTAKID: } & \multicolumn{5}{|l|}{ SUPVEY } & \multicolumn{2}{|l|}{ PANEL } \\
\hline & 1974 & 1977 & $\begin{array}{l}1980 \\
\text { CBS }\end{array}$ & $\begin{array}{l}1980 \\
\text { SCP }\end{array}$ & 1983 & 1981 & 1983 \\
\hline
\end{tabular}

\section{A. Oordeel eigen gezondheid}

Leeftijd en Geslacht
SES-index
Reglo \& Urbanis
Leefsituatie
Leefstijl
Soc. Participatie
P2 $^{2}$

Aangepaste $\mathbb{R}^{2}$

$\mathrm{A}$

\section{B. Envaren gezondheid \\ Leeftijd en Geslacht \\ SES-index}

Regio \& Urbanisatiegraad

Leefsituatie

Leefstiji

Soc. Participatie

$n^{2}$

Aangepaste $\mathrm{R}^{2}$

$\mathrm{R}$

\section{Chronische Aandoeningen}

Leefilid en Geslacht
SES-index
Regho \& Urbanisatiegraad
Leefisituatie
Leerstijl
Sociale Participatie
AP $^{2}$

Goodness of fit:

$\mathrm{Chi}^{2}$

df

significantie

$\begin{array}{lllllll}.020^{* *} & .117^{* * *} & .079^{* *} & .097^{* k} & .145^{* *} & .073^{* *} & .022^{* *} \\ .000 & .023^{* *} & .028^{* *} & .044^{* *} & .015^{* *} & .014^{* *} & .032^{* * *} \\ .003 & .007^{* *} & .002 & .001 & .013^{* *} & .001 & .006 \\ .008^{* *} & .009^{* *} & .028^{* *} & .018^{* *} & .007 & -7^{2} & . .2 \\ .009^{*} & .006 & .016^{* *} & .021^{* *} & .024^{* *} & .033 & .042 \\ .004 & .016^{* *} & .002 & .013^{* *} & .010 & .007 & .032^{* *} \\ .046 & .148 & .156 & .200 & .217 & .131 & .143 \\ .090 & .145 & .141 & .183 & .190 & .072 & .092 \\ .21 & .38 & .40 & .45 & .47 & .36 & .38\end{array}$

\begin{tabular}{|c|c|c|c|c|c|c|}
\hline $.041^{\text {** }}$ & $.054^{* * *}$ & $.066^{* *}$ & $.069^{\mathrm{*} * \mathrm{x}}$ & $.051^{*}$ & $.063^{* * *}$ & $.062^{* * *}$ \\
\hline $.012^{* *}$ & .025 & $.034^{\star x}$ & $.029^{\mathrm{kH}}$ & $.024^{*}$ & $.058^{* *}$ & $.040^{* * *}$ \\
\hline $.004^{\star * *}$ & $.014^{* *}$ & .000 & $.006^{\mathrm{x} *}$ & $.009^{\text {w:th }}$ & $.0 * 1$ & .009 \\
\hline $.020^{\text {wit }}$ & $.020^{1 * x}$ & $.040^{* * k}$ & $.010^{\mathrm{k} *}$ & $.051^{* * *}$ & $-{ }^{2}$ & $\alpha . z^{2 j}$ \\
\hline .009 & $.014^{* * *}$ & $.029^{* * *}$ & $.018^{* x}$ & $.019^{* * *}$ & .021 & .022 \\
\hline .003 & $.027^{\text {skik }}$ & $.003^{i}$ & $.024^{* * *}$ & $.025^{* *}$ & .002 & $.042^{*+1}$ \\
\hline .093 & .162 & .174 & .166 & .190 & .157 & .169 \\
\hline .077 & .143 & 159 & .147 & .161 & .100 & 120 \\
\hline 30 & 40 & .42 & .41 & .44 & .40 & .41 \\
\hline
\end{tabular}

\begin{tabular}{|c|c|c|c|c|c|c|}
\hline $.047^{\text {*** }}$ & $.060^{\operatorname{mix}}$ & $.054^{* *}$ & $.072^{m * *}$ & $.083^{* *}$ & $.110^{\text {*** }}$ & $.094^{* * *}$ \\
\hline $.005^{m i n}$ & $.005^{\text {**1 }}$ & $.037^{\text {Hin }}$ & $.010^{\text {中* }}$ & $.008^{\text {(1) }}$ & $.014^{* * *}$ & .001 \\
\hline $.007^{*}$ & $.006^{*}$ & $.009^{\prime \prime}$ & .004 & .004 & .014 & $.043^{* *}$ \\
\hline $.008^{\text {\#* }}$ & $.014^{i * *}$ & $.024^{*}$ & $.007^{* * *}$ & $.031^{* *}$ & $\ldots-^{21}$ & $-\infty^{2}$ \\
\hline . OH $1 * * *$ & .009 & .015 & .008 & $.019^{* *}$ & .030 & .032 \\
\hline .003 & $.018^{x *}$ & .001 & $.013^{\alpha *}$ & .010 & $.038^{* *}$ & .017 \\
\hline $.082^{*+1}$ & $.109^{* \text { "W }}$ & $.139^{* * *}$ & $.447^{\circ * x}$ & $153^{*}$ & $.180^{* \pi}$ & $.186^{2}$ \\
\hline .29 & .33 & .37 & .38 & .39 & .42 & .43 \\
\hline
\end{tabular}

\begin{tabular}{|c|c|c|c|c|c|c|}
\hline 1277.8 & 1387.3 & $1+78.8$ & 1241.6 & 1103.4 & 265.4 & 302. \\
\hline 1252 & 1325 & $1 * 51$ & 1206 & 1027 & 242 & 272 \\
\hline
\end{tabular}

1) IN SURVEY 1974 'TEVIGEDENHEID MET GEZONDHEID'; ${ }^{2}$ GEEN INDEXEN AANWEZIG IN MATERIMAL

** $P<0.05 ; * P<0.10$

van de gezamenlijk in de analyse opgenomen mechanismen. Wanneer de mechanismen onathankelijk zijn, zal de som van de verklaarde variantie van de afzonderlijke mechanismen gelijk zijn aan dlie van de gezamenlijk geanalyseerde modellen. Indien de mechanismen elkaar 
onderling beïnloeden wordt een deel van de in het ene model verklaarde variantie ook verklaard door de andere mechanismen en bilgevolg zal de som van de verklaarde varianties wan de afzonderlijke modellen groter zijn dan de variantie van de drie mechanismen gezamenlijk. Het is evenwel ook mogelijk dat de onderscheiden mechanismen elkaar versterken. In dat gewal zou juist, bil controle voor kenmerken in thet ene model, de van de indicatoren uit het andere model met gezondheid sterker worden, waardoor de gezamenlijk verklaarde variantie groter is dan de som van de verklaarde variantie van de modellen afzonderlijk. De eerste mogelijkheid stelt dat Klasse, status en burgerschap weliswaar verschillende aspecten wan de sociale stratificatie weergeven maar dat de relatie tussen deze aspecten zodanig is dat ze in feite slechts verschillende benamingen zijn woor dezelide stratificatie en het dus niet uitmaakt of men kenmerken van klasse, van status of van burgerschap neemt om verschillen ongezondheid tussen de sociaal-economische lagen te bepalen. De weede mogelijkheid stelt dat de onderscheiden aspecten van sociale differentiatie niet geheel los van elkaar staan. maar dat een combinatie van kenmerken van klasse. status en burgerschap een groter effect op gezondheid hebben dan elk van de kenmerken afzonderlijk. In dat geval zouden interactie-effecten moeten kunnen worden gespecificeerd.

In Tabel $X X$ wordt een overzicht gegeven van de verklaarde varianties door de afzonderlijke modellen en de drie modellen tesamen. Over het algemeen ontlopen de percentagas verklaarde variantie elkaar niet veel en is er, al naar gelang de gebruikte gezondhoidsindicator, enig verschill in de hoogte van de totaal verklaarde variantie. Aangezien de verschillen wisselend zijn kan worden geconcludeerd dat de onderscheiden modellen complementair zijhn en niet ten opzichte van elkaar concurreren in de verklaring van sociaal-economische gezondheidsverschillen. Klasse, status en burgerschap verklaren elk een deel van de verschillen in gezondheid wan Nederlandse hoofden wan huishouden. Vooralsnog is niet duidelijk of er ook interactie-effecten optreden, zodat niet kan worden gesteld dat ze elkaar versterken.

\subsubsection{Verklaringsmechanismen en SES-index}

Behalve de relaties tussen de drie onderscheiden mechanismen onderling, vraagt ook hun verhouding tot de sociaal-economische status, zoals gleindiceerd door opleiding, inkomen en beroepsgroep, om een nadere analyse. Het standpunt kan worden ingenomen dat de hier onderzochte mechanismen ter verklaring van gezondheidsverschillen tussen Nederlandse hoofden van huishoudens een wel erg indirecte relatie hebben tot de sociaal-economische kenmerken van de bevolking. Immers, de mechanismen zijn ontleend aan de vigarende theorieën over sociale differentiatie, welke voor de Nederlandse samenleving weliswaar sterke economische connotaties hebben, maar die ook los van de economische dimensie toepasbaar zijn. De relatie tussen leefsituatie, leefstijl of sociale participatie enerzijds en sociaal-economische status (SES-index) anderzijds, is blijkens de Tabel XIX en Tabel XX niet zo sterk, dat de verdeling over de hoofden van huishoudens van de drie genoemde mechanismen grotendeels wordt bepaald door de verdeling van de SES-index in de bevolking. Leefsituatie, leefwijze en sociale participatie leveren ook onathankelijk van de SES-index een bijdrage aan de verschillen in gezondheid.

De vraag is nu of en in hoeverre de drie mechanismen in de verklaring van gezondheidsverschillen in de plaats treden wan de saciaai-econamische status. Om deze vraag te kunnen beantwoorden zijin de veranderingen vastgesteld, die vóor en na invoering van de leefsituatie, leefwijze en sociale participatie optreden in de $\beta$ 's tussen de SES-index en de gezondheidsindicatoren. In het geval deze mechanismen bij de verklaring van gezondheidsverschillen in de plaats treden van de social-economische status, zou sprake moeten zijn wan een sterke afname in deze $\beta$ 's. 
Tabel tox Veranderingen in verklaarde variantie in gezondheid bij afzonderlijke en gezamenlijke analyse van de klasse, status en burgerschap.

\begin{tabular}{|c|c|c|c|c|c|c|c|}
\hline \multirow[b]{2}{*}{ BESTAND: } & \multicolumn{5}{|l|}{ SURVEY } & \multicolumn{2}{|c|}{ PANEL } \\
\hline & 1974 & 1977 & 1980 & 1980 & 1983 & 1981 & 1983 \\
\hline & & & $\mathrm{CBS}$ & SCP & & & \\
\hline
\end{tabular}

\section{Oordeel eigen gezondheid"}

Leeftijd, geslacht. SES-index, regio en urb. graad

Leofsituatie, leerstijl en soc. participatie afzonderlijk

Totaal alzonderink gezamenlijk $\left(\mathrm{R}^{2}\right)$

$\begin{array}{llllllll}.023 & .147 & .109 & .142 & .173 & .088 & .060 \\ & & & & & & \\ .021 & .031 & .046 & .052 & .041 & .040 & .074 \\ & & & & & & \\ .044 & .178 & .155 & .194 & .214 & .128 & .134 \\ .046 & .148 & .156 & .200 & .217 & .131 & .143\end{array}$

\section{Ervaren gezondheid}

Leettijd, geslacht, SES-index, reglio en urb. graad

Leefsituatie, leefstijl en soc. participatie afzonderlijk

Totaal afzonderlijk gezamenlijk $\left(R^{2}\right)$

$\begin{array}{lllllll}.057 & .093 & .100 & .104 & .084 & .096 & .111 \\ .032 & .061 & .071 & .060 & .095 & .023 & .064 \\ .089 & .154 & .171 & .164 & .179 & .119 & .175 \\ .093 & .162 & .174 & .166 & .190 & .157 & .169\end{array}$

\section{Chronisch ziek}

Leeftijd, geslacht SES-index, regio en urb. graad Leefsituatio, leefstij!

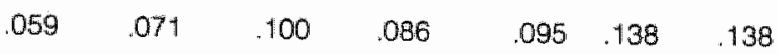
on soc. participatie alzonderlijk

Totaal afzonderlijk gezamenlijk $\left(R^{2}\right)$

$\begin{array}{lllllll}.022 & .041 & .040 & .028 & .060 & .068 & .049 \\ & & & & & & \\ .081 & .112 & .140 & .114 & .155 & .206 & .187 \\ .082 & .109 & .139 & .147 & .153 & .180 & .186\end{array}$

1) IN SURVEY 1974 TEVREOENHHEID MET GEZONDHEID

Inspectio van Tabel XXI leert dat de $\beta$ 's tussen SES-index en de gezondheidsindicatoren inderdaad veranderen. het sterkst door leefsituatie, het minst door sociale participatie; leefstijl veroorzaakt ook een significante daling van deze $\beta$ 's, maar gemiddeld is deze daling toch lets geringer dan die bij leefsituatie. Uit diezelfde tabel blijkt echter dat invoering van deze factoren de B's en b's tussen SES-index en gezondheid niet geheel daet verdwijnen. De conclusile kan dus zijn dat naast leefsituatie (klasse), leetwijze (status) en sociale participatie (burgerschap). 
Tabel XXI Relatie fussen de verschillende indicatoren voor gezondheid en de SES-index vodr en ne invering van drie mechanismen wan SEGW

\begin{tabular}{|c|c|c|c|c|c|c|c|}
\hline \multirow[b]{2}{*}{ BESTAND: } & \multicolumn{5}{|l|}{ SURWEY } & \multicolumn{2}{|l|}{ PANEL } \\
\hline & 1974 & 1977 & $\begin{array}{l}1980 \\
\text { Cas }\end{array}$ & $\begin{array}{l}1980 \\
\text { SCP }\end{array}$ & 1983 & 1981 & 1983 \\
\hline \multicolumn{8}{|c|}{ Oordeel Eigen Gezondheid" $(\beta)$} \\
\hline $\begin{array}{l}\text { SES-index } \\
\text { Regio \& }\end{array}$ & .123 & .163 & .183 & .223 & .136 & .148 & 186 \\
\hline Urbanisatiegraad & .122 & .160 & .184 & .222 & .127 & .117 & .195 \\
\hline Leefomstandigheden & .087 & .095 & .090 & .167 & .075 & $\ldots{ }^{2}$ & $\ldots \cdots^{23}$ \\
\hline Leefstijl & .073 & .135 & .153 & .192 & .056 & .078 & 149 \\
\hline Soc. Participatie & .120 & .125 & .182 & .195 & .111 & .103 & .225 \\
\hline Gecombineerde modellen & .019 & .063 & .065 & .126 & .018 & .071 & 176 \\
\hline \multicolumn{8}{|l|}{ Ervaren Gezondheid ( $\beta$ ) } \\
\hline $\begin{array}{l}\text { SES-index } \\
\text { Regio \& }\end{array}$ & -.114 & -.169 & -200 & -.181 & -.169 & -.244 & -.206 \\
\hline Urbanisatiegraad & -.120 & -.471 & -199 & -.180 & -.160 & -.244 & -213 \\
\hline Leefomstandigheden & -.063 & -.084 & -.099 & -.132 & -.034 & $\because-^{2 k}$ & $-n^{2 !}$ \\
\hline Leefistijl & -.099 & -132 & -155 & -.159 & -.114 & -.238 & -.189 \\
\hline Soc. Participatie & -.122 & -153 & -.200 & -160 & -.147 & -.233 & -.221 \\
\hline Gecombineerde modellen & $-.050+$ & $-.052^{* \text { ** }}$ & $-.062^{\star \star *}$ & -.080 & .004 &. .233 & -.167 \\
\hline \multicolumn{8}{|l|}{ Chronische Ziekten (b) } \\
\hline $\begin{array}{l}\text { SES-index } \\
\text { Fegio \& }\end{array}$ & -.182 & -.183 & -.565 & -.268 & -.226 & -.318 & -.075 \\
\hline Urbanisatiegraad & -.180 & -199 & -.561 & -.269 & $\times .210$ & -.327 & -.132 \\
\hline Leefomstandigheden & -.045 & -.268 & -.296 & -.194 & -.052 & $--^{2 x}$ & $-2^{2}$ \\
\hline Leerstifl & -.132 & -.227 & -.511 & -.260 & -143 & -317 & -103 \\
\hline Soc. Participatie & -.185 & -.162 & -.571 & -.266 & -216 & -.374 & -182 \\
\hline Gecombineerde modellen & -.006 &. .042 & -274 & -.149 & -.029 & -.346 & -.151 \\
\hline
\end{tabular}

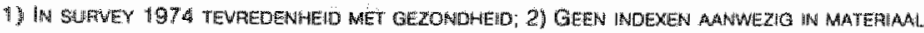

opleiding, inkomen en beroepsgroep (SES-index) verschillen in gezondheid veroorzaken. Met name woor sociale participatie kan worden geconstateerd dat in een aantal gevallen de 3 "s en b's tussen de SES-index en gezondheid niet zwakker, maar juist iets sterker worden. Dit betekent dat sociale participatie (burgerschap) de social-economische gezondheidsverschilIen maskeert, wat grond biedt voor de hypothese dat burgerschap beschermt tegen sociaaleconomische verschillen in gezondheid.

5.5.3 Aspecter van leefsituatie, leefwije, sociale participatie en gezondheidsverschillen Tot nu toe zijn de effecten van de samengestelde indexen voor leefsituatio, leefstijl en sociale participatie onderzocht, alsof alle aspecten binnen deze indexen een even grote bijdrage leveren aan de verklaring van verschillen in gezondheid. Het is echter zeer wel denkbaar dat slechts bepaalde aspecten in de leefsituatie, leefstijl en sociale participatie met name verantwoordellik zijn voor de gevonden verschillen in gezondheid. De hoogte van de B's an b's van 
de samensteliende indicatoren van de onderscheiden indexen moeten hierover uitsluitsel geven.

Tabel XXIll laat zien dat van de kenmerken van sociale klasse, de indexen voor woon- en werkomstandigheden in vrijwel alle survey-bestanden een duidelijke bijdrage leveren aan de verklaring van de gezondheidsverschillen. De bijdrage van de overige variabelen is hooguit in éen bestand significant, welke uitkomst daarom ook als min of meer toevallig kan worden beschouwd.

Van de statuskenmerken zijn de $\beta$ 's voor geloof en politieke voorkeur in meer dan twee bestanden significant, evenals die voor alcoholgebruik en sportieve activiteiten. Rooms-katholieke hoofden van huishoudens hebben over het geheel genomen een lets minder goede gezondheid dan protestantse hoofden van huishoudens. Ook een linkse politieke woorkeur hangt samen met een slechtere gezondheid (Tabel XXIII en Tabel XXIV).

Wat betreft het alcoholgebruik gaat een hogere consumptie gepaard met een minder goede gezondhaid. De slechtere gezondheid van geheelonthouders is in leder geval voor een deel te herleiden tot het relatief grote aantal ex-(zware)drinkers, dat om gezondheidsredenen met drinken is gestopt (Knibbe 1982. Shaper 1990). Voor roken werd geen duidelijke relatie met gezondheid gevonden; geen van de regressiecoêfficienten is echter positief. De schadelijke effecten van roken voor de gezondheid zijn niet terug te vinden in de gerapporteerde subjectieve gezondheid. Ook hier is waarschijilijk sprake van een selectiemeffect: onder de niet-rokers bevindern zich ex-rokers, die vanwege hun gezondheid met rokem zijn gestopt.

Met betrekking tot de kenmerken van burgerschap, blijken van de indexen voor sociale participatie muziekmaken, zingen in een kerkkoor, toneelspelen en andere creatieve activiteiten in de vrije tijd een meer dan toevallige samenhang met gezondheid te vertonen (Tabel XXV en Tabel XXVI). Na controle voor leeftijd, geslacht, SES-index, regio en urbanisatiegraad hebben sporten en het erop uit trekken in de natuur geen duidelijk effect op gezondheid. Het doen van vrijwilligerswerk en thet gebruik maken van Kruiswerk of van algemene maatschappelijke voorzieningen (AMW, JAC) heeft geen duidelijke samenhang met gezondheid. Daarentegen hebben mensen die gebruik maken van voorzieningen voor individuele hulpverlening (sociale raadslieden, sociaal psychiatrische diensten etc.) een wat minder goede gezondheid in vergelijking lof mensen die daar geen gebruik van maken. Ook hier kan sprake zijn van selectie of 'confounding: mensen met psychische klachten voelen zich minder gezond en zilin dat doorgaans ook. Het door velen gevonden beschermend effect van de huwelijkse staat kan in deze studie niet worden aangetoond. Dit bevreemdt enigszins omdat dit effect in de onderzoekspopulatie van overwegend mannen juist wel te verwachten zou zịn.

\subsection{Leefitjd, geslacht en sociaal-economische gezondheidsverschillen}

In de vooralgaande paragrafen is beschreven dat sociaal-economische gezondheildswerschillen zowel kunnen worden verklaard als gemaskeerd door de effecten van klasse, status en burgerschap. Deze drie begrippen overlappen gedeeltelijk met een algemene indeling in sociaal-economische strata op basis van opleiding, inkomen en beroepsgroep, woor een deel zijn het daarvan te onderscheiden kenmerken van sociale differentiatie. Zoals uiteengezet in $\$ 2.5 \mathrm{zijh}$ leettijd en geslacht niet alleen te zien als biologische kenmerken die de relatie tussen sociaal-economische gelaagdheid en gezondheid kunnen versluieren, maar ook als fundamentele kenmerken waarop sociale differentiatie plaats vindt. Op grond daarvan werd aangenomen dat in een model, waarin alle in deze studie onderscheiden aspecten van sociale differentiatie zijn opgenomen, leeftijd en geslacht geen afzonderlijke verklaringen meer zullen bieden voor 
Tabel XXIl Samenhang (B) van kenmerken van klasse met het oordeel over de eigen gezondheid, de ervaren gezondheid en de aanwezigheid van chronische aandoeningen (b)

\begin{tabular}{|c|c|c|c|c|c|c|c|}
\hline \multirow{3}{*}{ BESTAND: } & \multicolumn{5}{|l|}{ SURVEY } & \multicolumn{2}{|c|}{ PANEL } \\
\hline & 1974 & 1977 & 1980 & 1980 & 1983 & 1981 & 1983 \\
\hline & & & CBS & SCP & & & \\
\hline
\end{tabular}

OORDEEL EIGEN GEZONDHEID "

woonomstandigheden:

Inwonend

$\begin{array}{ccccc} & & .056^{*} & & .013 \\ .078^{*} & .087^{*} & .076^{*} & .095^{*} & .065^{*} \\ .026 & .024 & .049^{*} & & .021\end{array}$

Kwaliteit woonomgeving

$-.026$

$.024 \quad .049^{*}$

.021

werkomstandigheden:

Werkt

$\begin{array}{lllll}-.001 & .064 & .157^{*} & .147^{*} & .015\end{array}$

Kwaliteit werkomg.

$-.022$

.021

$.057^{*}$

$019 \quad .041$

bezit:

Duurzame goederen

$\begin{array}{lllll}-.048+ & .011 & .044 & -.062^{*} & -.035\end{array}$

durzame app. hobby

$\begin{array}{lllll}.021 & -.030 & .016 & -.004 & .022\end{array}$

\section{ERVAREN GEZONDHEID}

\section{woonomstandigheden:}

Inwonend

Kwaliteit woning

Kwaliteit woonomg.

werkomstandigheden:

\begin{tabular}{|c|c|c|c|c|c|}
\hline Werkt & -.027 & $-.078^{*}$ & $-149^{*}$ & -.056 & $-.115^{*}$ \\
\hline $\begin{array}{l}\text { Kwaliteit werkomg. } \\
\text { bezit: }\end{array}$ & $-.047^{*}$ & $-.070^{\pi}$ & $-.105^{*}$ & $-.086^{*}$ & $-.152^{*}$ \\
\hline Duurzame goederen & .023 & -.035 & .024 & .041 & $108^{*}$ \\
\hline Dure app. hobby & .004 & $.067^{*}$ & .009 & .027 & .032 \\
\hline
\end{tabular}

\section{CHRONISCHE AANDOENINGEN \\ woonomstandigheden:}

Inwonend

Kwaliteit woning

$\begin{array}{ccccc} & & -.472 & & -.187 \\ .152+ & .200^{*} & .215^{*} & .127+ & -.340^{*} \\ .015 & -.047 & -.052 & & -.153+\end{array}$

Kwaliteit woonomg.

$\begin{array}{lllll}.154^{*} & .093^{* *} & -.023 & & -.041 \\ -.012 & -.063^{*} & -.031 & .108^{*} & -.148^{*} \\ & & & & .000 \\ -.027 & -.078^{*} & -.149^{*} & -.056 & -.115^{*} \\ -.047^{*} & -.070^{*} & -.105^{*} & -.086^{*} & -.152^{*} \\ & & & & \\ .023 & -.035 & .024 & .041 & .108^{*} \\ .004 & .067^{*} & .009 & .027 & .032\end{array}$

werkomstandigheden:

Werkt

$-.210 \quad-.354+-.891 *-.405 *-.228$

Kwaliteit werkomg.

bezit:

Duurzame goederen

Dure app. hobby

$\begin{array}{lllll}.014 & .196 & -.162 & .118 & .304^{*} \\ -.158+ & -.078 & -.168+ & .113 & .043\end{array}$

"IN 1974 "TEVREDENHEID MET GEZONDHEID;" $P<0.05$; P<0.10 
Tabel XXill Samenhang (B) van kenmerken van status met het pordeel over de eigen gezondheid en de ervaren gezondheid

\begin{tabular}{|c|c|c|c|c|c|c|c|}
\hline \multirow[b]{2}{*}{ BESTAND: } & \multicolumn{5}{|l|}{ SURVEY } & \multicolumn{2}{|c|}{ PANEL } \\
\hline & 1974 & 1977 & 1980 & 1980 & 1983 & 1981 & 1983 \\
\hline & & & CBS & $\mathrm{SCP}$ & & & \\
\hline
\end{tabular}

\section{OORDEEL EIGEN GEZONDHEID}

gelloof:

\begin{tabular}{|c|c|c|c|c|c|c|c|}
\hline$r k$ & .010 & -.042 & $-.095^{* * *}$ & .041 & -.008 & .065 & .002 \\
\hline protestant & .033 & -.025 & $-.050+$ & $.070 * *$ & .043 & .086 & .082 \\
\hline anders & .010 & .010 & $-.068^{* *}$ & .023 & -.006 & -.069 & \\
\hline \multicolumn{8}{|l|}{ politieke voorkeur: } \\
\hline PudA & -.028 & .010 & -.002 & & -.027 & -.044 & .093 \\
\hline CDA & .000 & .039 & $.060+$ & & .027 & -.037 & .098 \\
\hline WD & .037 & .043 & .046 & & -.022 & .012 & .133 \\
\hline$D^{\prime} 66$ & & .008 & .004 & & .001 & -.070 & -.040 \\
\hline klein links & $-.059^{* i x}$ & .020 & .035 & & -.014 & -.069 & .038 \\
\hline confessioneel rechts & -026 & .037 & -.006 & & -.006 & -.028 & .062 \\
\hline rooki & & & .000 & $.056^{* *}$ & -.012 & \multicolumn{2}{|c|}{ loefwijzen: } \\
\hline drinkt & & & $.069+$ & $.073^{\text {**1*4}}$ & $.091^{* *}$ & .068 & $.175^{\text {** }}$ \\
\hline soort drinker & & & .005 & -.054 & -.051 & .025 & $-162^{\text {ind }}$ \\
\hline \multicolumn{8}{|l|}{ rije tijd besteding: } \\
\hline actiel & .031 & .057 & & $.114^{* * *}$ & .020 & & \\
\hline sportief & .030 & .012 & & $.071^{\text {* }}$ & $.098^{* * *}$ & & \\
\hline Cultudur partcipatie & .021 & -.036 & & -.006 & $.079+$ & & \\
\hline
\end{tabular}

\section{ERVAREN GEZONDHEID} geloof:

\begin{tabular}{|c|c|c|c|c|c|c|c|}
\hline$r . k$. & -.008 & $.058+$ & $.064^{* *}$ & -.038 & .009 & -.087 & .003 \\
\hline protestant & -.050 & -.012 & .014 & $-.057+$ & .021 & -.072 & -.007 \\
\hline $\begin{array}{l}\text { anders } \\
\text { politieke voorkeur: }\end{array}$ & -.033 & $-.011 * *$ & .033 & .019 & .032 & .020 & \\
\hline PVdA & .031 & -.013 & .032 & & $.086^{\text {m*x }}$ & .027 & -.001 \\
\hline CDA & .007 & -.025 & $-.094^{* *}$ & & .029 & -.033 & -.057 \\
\hline WVD & .012 & -.076 & -.028 & & .040 & .055 & -.020 \\
\hline$D^{\prime} 66$ & & -.034 & -.024 & & .003 & .0 .011 & .059 \\
\hline klein links & .022 & .015 & -.015 & & $.052+$ & .040 & -.072 \\
\hline $\begin{array}{l}\text { confessioneel rechts } \\
\text { leefwijzen: }\end{array}$ & .020 & -.023 & -.006 & & .030 &. .007 & .013 \\
\hline rookt & & & $.044+$ & .019 & .019 & .036 & .004 \\
\hline drinkt & & & $-.185^{\text {i*k }}$ & $-080^{* *}$ & -.017 & -.013 & $-.153^{m+x}$ \\
\hline $\begin{array}{l}\text { soort drinker } \\
\text { mijtijd-besteding: }\end{array}$ & & & $.107^{\mathrm{iw*}}$ & .046 & .009 & -.039 & .088 \\
\hline actief & .054 & .023 & & .005 & -.027 & & \\
\hline sportiof & $-.105^{\text {*ik }}$ & $-.095^{* *}$ & & $-.134^{* * *}$ & $-.104^{* *}$ & & \\
\hline cultuur participartio & -.048 & $-.026^{* *}$ & & -.002 & -.038 & & \\
\hline
\end{tabular}

** $P<0.05_{i}+p<0.10$ 
Tabel XXIV Samenhang (b) tussen kenmerken van status met de aanwezigheid van chronische aandoeningen

\begin{tabular}{|c|c|c|c|c|c|c|c|}
\hline \multirow[b]{2}{*}{ DESTAND: } & \multicolumn{5}{|l|}{ SURVEY } & \multicolumn{2}{|l|}{ PANEL } \\
\hline & 1974 & 1977 & $\begin{array}{l}1980 \\
\mathrm{CBS}\end{array}$ & $\begin{array}{r}1980 \\
\text { SCP }\end{array}$ & 1983 & 1981 & 1983 \\
\hline \multicolumn{8}{|l|}{ geloot: } \\
\hline rk & .171 & .173 & -.141 & -.057 & .107 & .270 & -.268 \\
\hline protestant & $-.387^{\star *}$ & -.013 & -.208 & -.101 & $-.295^{* *}$ & -.155 & -.020 \\
\hline anders & 240 & -.283 & -.026 & .153 & .218 & .756 & \\
\hline \multicolumn{8}{|l|}{ poltitieke voorkeur: } \\
\hline PUdA & .100 & -.175 & -.051 & & .152 & .254 & .55 \\
\hline CDA & -.139 & -1.45 & -.325 & & .067 & .116 & 1.112 \\
\hline VWD & -.131 & $-.341^{* *}$ & -.144 & & .155 & 482 & .822 \\
\hline$D^{\prime} 66$ & & & -.056 & & -.535 & & -3.943 \\
\hline kein links & $.342^{*}$ & .326 & -.451 & & 2002 & .213 & 1.068 \\
\hline confessioneel rechts & & & 1.444 & & & .129 & \\
\hline \multicolumn{8}{|l|}{ lleefwijzen: } \\
\hline rookt & & & .062 & -.072 & -.115 & .342 & .443 \\
\hline lichte drinker & & & .165 & & .651 & -.457 & .000 \\
\hline matige drinker & & & .266 & -.512 & $.742^{*}$ & -.012 & .336 \\
\hline stevige drinker & & & & -.506 & $.994^{\text {** }}$ & -181 & .292 \\
\hline drinkt niet & & & -.822 & 1.208 & -.485 & & \\
\hline \multicolumn{8}{|l|}{ vije-tijdbesteding: } \\
\hline actiel & -.030 & -.014 & & -.044 & $313^{\text {iki }}$ & & \\
\hline sportief & -.121 & -.123 & &. .080 & -112 & & \\
\hline cultuur participatie & -.075 & .104 & & -.136 & $-.374^{* *}$ & & \\
\hline
\end{tabular}

socilaal-economische gezondheidsverschillen. Verwacht werd dat de effecten valn leeftijd en geslacht op verschillen in gezondheid geheel of gedeeltelijk zouden verdwijnen na invoering

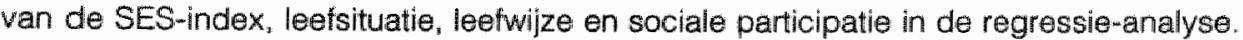

Uit Tabel XXVII walt op te maken dat met name de relatie tussen geslacht en gezondheid onder invloed staat van sociale differentiatie. Hierbij moet worden opgemerkt, dat dit verband is niet in elk bestand is terug te vinden. Met name voor leeftijd blijkt een duidelijke relatie met de gezondheidsindicatoren te bestaan. In de meeste bestanden wordt de relatie van zowel geslachi als leeftijd met gezondheid beduidend verzwakt door invoering van de SES-index. Uit deze daling van de $\beta$ 's kan worden geconcludeerd dat leeftijd en geslacht in belangrijke mate de relatie van de sociaal-economische status mel gezondheid bepalen. Opvallend is evenwel dat invoering wan de SES-index de samenhangen van leftijd en geslacht met gezondheid verzwakt, maar dat deze na inwoering van kenmerken van klasse, status en burgerschap weer enigszins stijgen (Tabel XXVII). Het lijkt er op dat verschillen in gezondheid tussen mannen en 
De invloed van kasse, stais en burgerschap op subjectieve gezondheld

Tabel XXV Samenharg (B) van kenmerken van burgerschap met het oordeel over de eigen gezondheid en de ervaren gezondheid

\begin{tabular}{|c|c|c|c|c|c|c|c|}
\hline \multirow[b]{2}{*}{ BESTAND: } & \multicolumn{5}{|l|}{ SUFVEY } & \multicolumn{2}{|l|}{ PANEL } \\
\hline & 1974 & 1977 & $\begin{array}{l}1980 \\
\text { CBS }\end{array}$ & $\begin{array}{l}1980 \\
\text { SCP }\end{array}$ & 1983 & 1981 & 1983 \\
\hline \multicolumn{8}{|c|}{$\begin{array}{l}\text { OORDEEL EIGEN GEZONDHEID } \\
\text { burgerijjke staat: }\end{array}$} \\
\hline gehuwd & .024 & .004 & .000 & -.061 & .003 & -.006 & .132 \\
\hline gescheiden & & -.019 & -.037 & -.005 & .039 & -.087 & .036 \\
\hline verweduwd & & .040 & .026 &. .006 & .007 & -.038 & $.261 * *$ \\
\hline \multicolumn{8}{|l|}{ lidmaatschap: } \\
\hline maatsch org & -.008 & .007 & & .028 & .036 & & \\
\hline cultuur particip. org & -.033 & .028 & & .041 & .040 & & \\
\hline $\begin{array}{l}\text { collectieve vrije tijd } \\
\text { vrijwilligerswerk: }\end{array}$ & -.033 & .009 & & .000 &. .027 & & \\
\hline wrijwilligerswerk & .056 & .026 & & .011 & -.030 & & \\
\hline indivduele belangenbeh. & .023 & $.043^{*}$ & & -.007 & -.032 & & \\
\hline culturele participatie & -.036 & .004 & & $-.070^{* *}$ & .027 & & \\
\hline \multicolumn{8}{|c|}{ GEBRUIK VAN VOORZIENINGEN: } \\
\hline sociaal-medisch & & .016 & & -.007 & .006 & & \\
\hline maatschappelijk & & $-.154^{\operatorname{mix}}$ & &. .020 & .013 & & \\
\hline persoonlijke hulp & & $.059^{*}$ & & $-.078^{* *}$ &. $.066^{* *}$ & & \\
\hline \multicolumn{8}{|l|}{$\begin{array}{l}\text { ERVAREN GEZONDHEID } \\
\text { burgerlike staat: }\end{array}$} \\
\hline gehuwd & -.071 & $.012^{* *}$ & .055 & $.103^{* *}$ & -.049 & -.058 & $-.377^{* *}$ \\
\hline gescheiden & & -.041 & $.046^{*}$ & .030 & .027 & .012 & $-.152^{\text {** }}$ \\
\hline werweduwd & & .010 & $=.022$ & .042 & .040 & -.005 & $-.222^{* * *}$ \\
\hline \multicolumn{8}{|l|}{ lidmaatschap: } \\
\hline maatschi, org & .018 & $.051^{* * *}$ & & .012 & -.020 & & \\
\hline culltud particip. org & .014 & .000 & & .014 & .026 & & \\
\hline $\begin{array}{l}\text { collectieve wrije tijd } \\
\text { wrilwilligerswerk: }\end{array}$ & .009 & $.018^{* * *}$ & & .037 & .023 & & \\
\hline vitiwilligerswerk & -.006 & .025 & & .010 & .050 & & \\
\hline indivduele belangbeh. & .020 & $-.027^{* *}$ & & .005 & .011 & & \\
\hline $\begin{array}{l}\text { cultuur participatie } \\
\text { gebruik van voorzieningen: }\end{array}$ & .002 & $-.002^{* *}$ & & .031 & .020 & & \\
\hline sociaal-medisch & & $-.002^{* *}$ & & .003 & .006 & & \\
\hline Trinaatschappelijk & & $.157^{* \star *}$ & & .038 & .015 & & \\
\hline persoonlijke hulp & & $-.003^{*}$ & & $132^{\text {*** }}$ & $.139^{* *}$ & & \\
\hline
\end{tabular}


Tabel XXVI Samenhang (b) wan kenmerken wan burgerschap met de aanwezigheid van chronische aandoeningen

\begin{tabular}{|c|c|c|c|c|c|c|c|}
\hline \multirow{3}{*}{ BESTAND: } & \multicolumn{5}{|l|}{ SURVEY } & \multicolumn{2}{|l|}{ P.ANEL } \\
\hline & 1974 & 1977 & 1980 & 1980 & 1983 & 1981 & 1983 \\
\hline & & & CBS & SCP & & & \\
\hline
\end{tabular}

\section{CHRONISCHE AANDOENINGEN burgerlijke staat:}

gehuwd $\quad-.010$

gescheiden

$\begin{array}{rrrcrrr}-.010 & -.153 & .143 & .046 & -.335 & 2.248 & .638 \\ & .637 & .195 & -.441^{*} & .543 & -4.549 & .329 \\ & -.371 & -.331 & .292 & .038 & -1.092\end{array}$

verweduwd

$\begin{array}{llll}.048 & .037 & -.045 & -.032 \\ 111 & .097 & .063 & -.134^{*} \\ .152^{*} & .069 & .028 & .059\end{array}$

lidmmatschap:

maatsch org

cultuur particip. org

collectieve vrije tijd

$.152 \quad .069$

vrijwilligerswerk:

wrijwilligerswerk

$\begin{array}{lr}-.071 & -.030 \\ -.029 & .006\end{array}$

. .032

.047

indivduele belangenbeh.

.068

$-.020$

.086

.068

cultuur participatio

$.068 \quad-.020$

.010

.101

gebruik van voorzieningen:

sociaal-medisch

maalschappelijk

persoonlijke hulp

$\begin{array}{lll}.129 & .102 & .089 \\ .519^{* *} & .057 & .070 \\ .125 & .279^{* *} & .211^{* *}\end{array}$

$p<0.05 ; * P<0.10$

wrouwen voor een groot deel kunnen worden verklaard door verschillen in opleiding, inkomen en sociale groep, maar dat klasse, status en burgerschap deze verschillen tussen de geslachten weer accentueren en dat zij de leeftijdsverschillen nuanceren. Deze uitkomsten wilzen erop dat, althans in relatie tot gezondheid, de dimensies klasse, status en burgerschap voor jongeren en ouderen en voor mannen en vrouwen niet dezelfde effecten hebben. Alles bijeen genomen moet onderstelling 4 worden verworpen: ook nadlat alle andere aspecten van sociale gelaagdheid in aanmerking zijn genomen, blijven leettijd en geslacht een rol spelen in de sociale differentiatie en in de daarmee samenhangende gezondheidsverschillen. 
Tabal XXVI B-coefficienten van leeftijd en geslacht met drie maten van subjectieve gezondheid voúr en ná invoering van kenmerken van sociale clifferentiatie

\begin{tabular}{|c|c|c|c|c|c|c|c|}
\hline \multirow{3}{*}{ DESTAND: } & \multicolumn{5}{|l|}{ SUPVEY } & \multicolumn{2}{|l|}{ PANEL } \\
\hline & 1974 & 1977 & 1980 & 1980 & 1983 & 1981 & 1983 \\
\hline & & & CBS & SCP & & & \\
\hline \multicolumn{8}{|c|}{$\begin{array}{l}\text { OORDEEL EIGEN GEZONDHEID } \\
\text { woor invoering }\end{array}$} \\
\hline geslacht & $-.049^{m}$ & $-.051^{* * x}$ & $-.043^{*}$ & -.028 & $-.045^{\star}$ & $-.091^{*}$ & $-.025^{* * *}$ \\
\hline $\begin{array}{l}\text { leeftijd } \\
\text { na invoering }\end{array}$ & $-.126^{*}$ & -.323 & $-.266^{* *}$ & $-304^{* * *}$ & $-.377^{* *}$ & $-.257^{* * *}$ & $-.144^{* * *}$ \\
\hline geslacht & -.042 & -.016 & .032 & .015 & -.041 & -.045 & -.057 \\
\hline leeftifd & $-.129 * *$ & $-.250^{* * *}$ & $-.144^{* * *}$ & $-.092^{* *}$ & $-.331+*$ & $-.247^{* *}$ & $-.168^{* *}$ \\
\hline \multicolumn{8}{|c|}{$\begin{array}{l}\text { ERVAREN GEZONDHEID } \\
\text { woór invoering }\end{array}$} \\
\hline geslacht & $.097^{\text {** }}$ & $148^{* * *}$ & $.083^{\text {atik }}$ & $.121^{\star *}$ & $.124^{* *}$ & $.175^{\text {** }}$ & $.147^{\text {*at }}$ \\
\hline $\begin{array}{l}\text { leeftijd } \\
\text { na invoering }\end{array}$ & $.164^{\text {** }}$ & $.001^{\text {kit }}$ & $.223^{\text {*it }}$ & $210^{* *}$ & $186^{m *}$ & $.182^{* *}$ & $.179^{\text {id*k }}$ \\
\hline geslacht & .041 & $128^{* t}$ & $.064^{*}$ & $.113^{* * *}$ & $.107^{* * *}$ & $.115^{\star}$ & -.002 \\
\hline leaftiid & $.125^{* *}$ & $.061 *$ & $.136^{* * *}$ & $.104^{* *}$ & $.092^{* \star}$ & $.178^{* *}$ & $.140^{* *}$ \\
\hline \multicolumn{8}{|c|}{$\begin{array}{l}\text { CHAONISCHE AANDOENINGEN } \\
\text { vó́r invoering }\end{array}$} \\
\hline geslacht & -.322 & $423^{ \pm *}$ & -.009 & $.340^{\text {*** }}$ & $.743^{* *}$ & .115 & .200 \\
\hline $\begin{array}{l}\text { leettijd } \\
\text { na inwoering }\end{array}$ & $.035^{\text {m*t }}$ & $.034^{\text {k\# }}$ & $.034^{* *}$ & $.039^{\text {ix }}$ & $.046^{* *}$ & $.070^{* *}$ & $.062^{1 * *}$ \\
\hline geslacht & -.359 & .259 & -.339 & .051 & $.400^{* *}$ & 624 & .854 \\
\hline leeftijd & .030 & $.031^{* *}$ & $.016^{* *}$ & $.025^{\text {** }}$ & $.056^{k *}$ & $.072^{* *}$ & $.061^{1 *}$ \\
\hline$* P<0.05$ & & & & & & & \\
\hline
\end{tabular}




\subsection{Inleiding}

In de voorafgaande analyses is ingegaan op de vraag of en zo ja, in welke mate sociaaleconomische gezondheidsverschillen samenhangen met status, klasse en burgerschap. Het bleek, dat klasse en status voor een deel verantwoordelijk zijn voor sociaal-economische gezondheidsverschillen in de Nederlandse bevolking en dat burgerschap een zekere bescher. ming biedt tegen deze verschillen. Uit de analyses bleek bovendien dat de drie dimensies van socialle differentiatie onathankelijk van elkaar een bijorage leveren aan de verklaring van verschillen in gezondheid tussen de sociale lagen. Deze bevindingen komen overeen met resultaten van andere studies, waarin werd aangetoond dat sociaal-economische gezondheidsverschillen multifactorieel worden bepaald door zowel genetische uitrusting als ook door kenmerken van de opvoedingsomgeving en door de huidige leefomstandigheden en leefstijl (Abel 1991; Porter, Hook 1980; Kuh. Wadsworth 1993; Lichtenstein, Harris, Pedersen, McClearn 1992). Ook kwam uit de analyses naar voren dat het belang van sociaal-economische kermerken varieert met de gebruikte maat voor gezondheid. Onder deze condities is het niet te verwachten dat sociaal-economische gezondheidsverschillen volledig kunnen worden verklaard uit sociale en culturele kenmerken van de teefomgeving. Nu echter is gebleken dat onderscheiden aspecten van klasse, status en burgerschap elk afzonderlijk bijdragen aan de verklaring van sociaal-economische gezondheidsverschillen "kan well worden nagegaan of de verschillende kenmerken van sociale differentiatie elkaar versterken of verzwakken bil de verklaring van deze gezondheidsverschillen.

Voor zover kon worden nagaan, heeft op dit gebied nog weinig formele theorievorming plaats gevonden. De hypothesen en analyses, die in dit hoofdstuk worden gepresenteerd, zijn daarom meer beschrijvend en exploratief van aard dan in de voorafgaande. Wel kunnen, evenals in de woorafgaande hoofdstukken, de relaties die zijn geëxploreerd in het bestand van het survey 1983, direct op consistentie worden getoetst in de overige bestanden.

De interactie-effecten kunnen zich zowel binnen als tussen de onderscheiden mechanismen voordoen. Hoewel het interessant zou zijn om de interactie-effecten tussen klasse, status en burgerschap te specificeren, is daarvan afgezien omdat het noch mogelijk was indices to definierren die zowel theoretisch van belang leken als inhoudelijk interpreteerbaar noch konden hypotheses op basis van dit materiaal geconstrueerd worden. In dit hoofdstuk worden interac. tle-effecten gespecificeerd binnen de mechanismen. Deze indices woldoen wel aan de hierbovern genoemde eisen.

\subsection{Aanzetten tot de mechanismen van sociaal-economische gezondheidsverschillen.}

Zoals is uiteengezet in de eerste hoofdstukken "postuleert het begrip klasse dat verschillen in gezondheid teweeg worden gebracht door de ongellike mate van blootstelling aan adversieve levensomstandigheden van de onderscheiden sociale klassen. Met name zouden in de laagste klassen mensen door inadequate woon-en werkomstandigheden fysiek meer worden belast dan in de hogere klassen, waardoor zij een grotere kans lopen om ziek of ongezond te worden. 
De invloed van klasse, status en burgerschap op subjectieve gezondheid

Voor zover sociale status gelijk wordt gesteld aan leefstijl en daarmee aan consumptie en aan activiteiten, die mensen in hun vrije tijd ondememen, worden verschillen in gezondheid toegeschreven aan werschillen in het gebruik van onder andere genotmiddelen (alcohol, tabak) en medicijnen tussen de onderscheiden sociale status-categorieën en aan verschillen in lichaamsbeweging. Mensen die zwaar roken en drinken (alcohol) en niet erg actief hun wrije tijd besteden, worden geacht een grotere kans te lopen voortidig te overlijen of een slechtere gezondheid te krijgen dan mensen die hun wrije tijd actief besteden en slechts af en woe een glas alcohol nuttigen. Voorzover sociale status betrekking heeft op het sociale prestige van beroepsgroepen wordt de betere gezondheid wan mensen met een hoge sociale status toegeschreven aan hun geringere blootstelling aan sociaal belastende omstandigheden: hun sociale krediet en zekerheid zijn groter.

Ook voor burgerschap lijkt deze redenering op te gaan. Er van uitgaande dat mensen elkaar nodig hebben am zich te weer te stellen tegen de onzekerheden en problemen van het dagelijks leven: zouden degenen die geen gebruik maken van hun burgerrecht op wrije vereniging en niet of nauwelijks met andere leden van de samenleving in contact komen "kwetsbaarder zijn dan degenen die zich opgenomen weten in de gemeenschap en zich gesteund weten door familie en vrienden.

\subsubsection{Cumulatio van effecten}

Het gemeenschappelijke in al deze verklaringen is dat bij een cumulatie van factoren die de gezondheid bedreigen de kans op onwelbevinden en ziekte groter is dan bij een cumulatie van gunstige omstandigheden. In het vooratgaande hoofdstuk werd beschreven dat in een model ter verklaring van gezondheid naast basale kenmerken van sociale differentiatie, zoals leeftijd, geslacht en de gemeenschappelijke kenmerken van sociale differentiatie zoals deze tot uiting komen in de SES-index, ook kenmerken wan klasse, status en burgerschap een extra bijdrage leveren. Dat wil zeggen, dat ongeacht iemands leeftijd en geslacht en ongeacht de sociale laag waartoe hij of zil op basis van opleiding, inkomen en beroep behoort, slechte werkomstandigheden en slechte woonomstandigheden elk een eigen bijdrage leveren aan de werklaring van (on)gezondheid en dat "overigens in geringere mate, ook de afzonderlike kenmerken van status en burgerschap elk een eigen bijdrage leveren aan de verklaring van gezondheid. Omdat in dit model kenmerken van sociale differentiatie zijn gebruikt om verschillen in gezondheid te verklaren, wordt dit het Sociaal-Economische Gezondheidsverschillen (SEGV-)Model genoemd. Belangrijk is hier dat de onderscheiden kenmerken voor sociale differentiatio elkaar niet 'wegdrukken', wail het geval zou zijn als inadequate werkomstandigheden vrijwel altijd gepaard gaan met inadequate huisvesting of als een ongezonde leefwijze altijd samengaat met een gebrek aan burgerschap, bijvoorbeeld orndat mensen die geen deel uitmaken van de samenleving in alcohol en tabak vergetelheid zoeken of omdat alle zware drinkers sociaal geisoleerd te raken.

Nu dit niet het geval blijkt te zlin, doet de vraag zich voor of de kenmerken van Klasse, status en burgerschap elkaar versterken bij het verklaren van gezondheidsverschillen: zijn mensen die slecht zijn gehuisvest en onder ongunstige amstandigheden werken ongezonder dan mensen die slechts onder éen van deze belastende omstandigheden leven of omgekeerd, zijn mensen die het in alles voor de wind gaat gezonder dan mensen die aan enige vorm van belasting zijn blootgesteld? Het verklarend mechanisme voor het bestaan van sociaal-economische gezondheidsverschillen onderstelt dat de cumulatie van adversieve of juist gunstige levensomstandigheden zich voordoet in de lagere respectievelijk hogere socialle lagen. Het wordt daarom hier het cumulatie-model genoemd. Vraag is of naast het additieve model dat in de vorige hoofdstukken is uitgewerkt, dit cumulatiemodel een extra bijdrage levert aan de verklaring van sociaaleconomische gezondheidsverschillen.

In operationele termen komt het in de vorige hoofdstukken uitgewerkte SEGV-model neer op: 
gezondheid $=$ [regio + urbanisatiegraad + Heetijd + glaslacht + ses + [klasse + status + burgerschap]

De accolades geven covariaten aan, factoren die gezondheid wel beilnwloeden maar grotendeels los staan van het mechanisme van sociaal-economische gezondheidsverschillen.

Het model van cumulatieve effecten voor achtereenvolgens klasse, status em burgerschap kan als wolgt worden weergegeven:

Kasse gezondheid = SEGV-model * (woonomgeving) "(woon-) * (werkomstandigheden) "(bazil)

Status gezondheid = SEGV-model + (roken "driken) ${ }^{*}$ (actieve vrije - tijdsbesteding)

Burgerschap gezondheid = SEGW-model + (lidmaakchap * viwilligerswerk * voorzleningen)

In deze modellen wordt dus ondersteld dat de cumulatie-termen, die aan het SEGV-model worden toegevoegd, een extra bijdrage leveren aan de variatie in gezondheid.

Aparte aandacht dient nog te worden besteed aan de bijdrage van de sociaal-economische laag waartoe men behoort aan deze verklaring. In het woorgaande hoofdstuk bleek dat weliswaar de bijdrage wan de SES-index aan de variatie in gezondheid afnam na introductie van klasse-en statuskenmerken, maar zeker niet verdween. Invoering van kenmerken van burgerschap versterkteri de bijdrage van de SES-index aan de verklaring van gezondheidsverschillen. In de analyse van de cumulatieve modellen voor klasse, status en burgerschap zal dus ook worden nagleglaan of en un welke richting de cumulatie van belastende factoren de bijdrage van de SES-index aan het SEGV-model beinvloedt. Tenslotte wordt nog onderzocht in hoeverre het bestaan van sociaaleconomische differentiatie zelf reden is voor het woorkomen van verschillen in gezondheid tussen mensen. Het zijn dan niet alleen de omstandigheden zoals deze samenhangen met de SES-index maar het is deze index zelf die een rol speelt bij de verklaring van gezondheidsverschillen.

Modelmatig kan dit worden weergegeven als:

SES als gezondheidsrisico: gezondheld = SEGV-model + (kiasse+status + burgerschap) * ses

In bovenstaande modellen wordt er steeds van uitgegaan dat verschillen in gezondheid met behulp van regressie-analyse kunnen worden beschreven als de gewogen som van de kenmerken van status, klasse, burgerschap en de interactie van deze kenmerken. Deze relatief simpele modellen zouden in principe nog kunnen worden verfind door rekening te houden met mogelijk multiplicatiove effecten: weliswaar geldt dan nog steeds hoe meer curnulatie hoe slechter de gezondheid of hoe minder belastende omstandigheden des te beter de gezondheid, matar de effecten zouden sterker zijn. Bill gebrek aan theorievorming over de aard van deze relaties wordt in deze studie een relatief simpel additief model gebruikt. De bevindingen uit deze studie kunnen aanleiding bileden dit model aan te scherpen.

\subsubsection{Sociale inconsistentie}

Met betrekking tot de relatie tussen sociale gelaagdheid en gezondheid bestaat er een sociologische traditie, waarin inconsistenties binnen en tussen status, klasse en burgerschap verantwoordelijk worden gesteld voor spanningen tussen de verschillende levensgebleden varn het individu, die zijn gezondheid negatief kunnen beirnvloeden. Deze soclale spanningen of inconsistenties zouden tot uitdrukking komen in lichamelijke klachten en psychische problemen. Statusinconsistentie, het uiteenlopen in één perscon van klasse-kenmerken en leefstijl of van leefstij]. en burgerschap of van alle drie, wordt verondersteld het ontstaan van cardio-vasculaire aandoeningen te beilnvloeden (Dressler 1988;1993, Siegrist 1990). Chronische stress wordt daarbil) gezien als het mechanisme dat de verbinding zou kunnen leggen tussen status-inconsistenties en gezondheid. Dit verband is tot op heden echter niet overtuigend aangetoond. Discrepanties 
tussen leefstiflen en klasse zouden ook een uiting kunnen zijn van een gebrekkig vermogen om de omgeving te beheersen. Siegrist (0.c) laat zien dat dit laatste en hoge werkdruk ekaar versterken bij het ontstaan van cardio-vasculaire aandoeningen.

Hiervan ütgaande zou kumen worden verondersteld dat mensen, bij wie opleiding, inkomen en beroep uiteenlopen, of bij wie klasse-, staus- en burgerschapskenmerken niet met elkaar in overeenstemining zijn, minder goed in staat zijn om hun omgeving te beheersen of meer onderhevig. zijn aan chronische stress en bijgevolg ongezonder zijn. In plaats van te onderstellen dat de negatieve of positieve effecten van de kenmerken van klasse, status en burgerschap elkaar versterken (cumulatie-model), wordt in dit model juist ondersteld dat discrepanties in deze kenmerken een bijdrage leveren aan sociaal-economische verschillen in gezondheid. Dit model wordt daarom aangeduid als inconsistentie-model.

Het cumulatie- en het consistentiemodel interpreteren de kenmerken van klasse, status en burgerschap op verschillende wijze. In het curnulatiemodel worden de met een lage klasse, status of burgerschap samenhangende kenmerken geachit een direct effect te hebben op gezondheid doordat de leefsituatio of leefstij het individu blootstellen aan gezondheid- schadende factoren, terwijl in het consistentie-model discrepanties tussen en binnen de kenmerken van klasse, status en burgerschap een situatie van chronische stress oproepen. De modellen zijn niet tegelijk te toetsen indien adversieve levensomstandigheden, riskante gewoonten of gebrek aan burgerschap bestaan uit kenmerken waarvoor de sociale waardering sterk varieert, omdat in dat geval er een grote zo niet perfecte samenhang bestaat tussen de cumulatie- en de consistentie-index. In alle andere gevallen zijn beide indexen onafhankelijk en is thet mogelijk dat zij elkaar aanvulien.

\subsection{Methode}

De onderscheiden modellen kunnen met behulp van regressie-analyse worden getoetst op dezelfde wijze als in de voorgaande hoofdsitukken voor het SEGV-model is gebeurd. De basis voor toetsing is nu of gegeven de bijdrage van klasse, status, burgerschap en de SES-index, cumulatie van adversieve levensomstandigheden en -gewoontes, dan wel sociale inconsistenties daarin, een eigen bijdrage leveren aan de verklaring van verschillen in gezondheid in de bevolking. Daarbij dient er op te worden gelet dat zowel de indexen voor cumulatie als die voor inconsistentie noch onderling, noch met de corspronkelijke indexen een te sterke samenthang vertonen (multicollineariteit). Bovendien mogen deze indexen niet erg scheef zijn verdeeld en moet er op worden toegezien dat niet een paar respondenten door een woor hen specifieke combinatie van kenmerken in belangrijke mate de samenhang met de indicatoren voor gezondheid bepalen (leverage).

In de eerdere analyses is voor multicollineariteit en leverage gecontroleerd met behulp van de Mehalonobis afstand. Omdat nieuwe variabelen aan de vergelijking zijn toegevoegd, zouden deze afstanden, indien de indices voor cumulatie en inconsistentie de oorspronkelijke kenmerken van kasse, status en burgerschap sterk beïnvloedem, in belangrijke mate kunnen verschillen van de afstanden, die zijr berekend voor het additieve model. Dit zou betekenen dal de modellen voor cumulatie en inconsistentie op een andere selectie uit de steekproeven van de Nederlandse bewolking worden getoetst dan die waarop de toetsing van het additieve model is gebaseerd. In dit geval zouden de uitkomsten van deze analyses niet meer goed met elkaar zijn te vergelijken. Zelfs is het denkbaar, dat door nieuwe afstanden heteffect van de onderscheiden modellen teniet wordt gedaan, omdal de enkelingen, bil wie er duidelijk sprake is van een voor hen specifiek samengaan van adversieve of gezondheid bevorderende levensomstandigheden, van de analyse worden uitgesloten juist op grond van het verschil met de meerderheid van de respondenten in de steekproeven. Bij het gebruik van opnieuw berekende afstanden zouden op basis van statistische criteria (te grote afstand tot het centroide van alle respondenten, l.e. te afwijkend van de bulk van de respondenten), de toetsing van de hiervoor geuite onderstellingen een negatief 
resultaat opleveren, terwijl de theoretisch onderstelde combinatie van kenmerken wel in de bevolking vookkomt maar door hun uniciteit van analyse zijn uitgesloten. Om deze paradoxale situatie te vermijden worden de berekeningen uitgevoerd met de in eerdere analyses gebrulkte afstanden. Wel is nagegaan hoe de oorspronkelijke afstanden en die op basis van cumulatie: en inconsistentie- indexen zich tot elkaar verhouden. Indien ze een lineaire samenhang vertonen en er geen duidelijke 'sprongen' in zijn aan te wijzen, is niet te verwachten dat de nieuw berekende afstanden tot grote verschillen in uitkomsten zouden hebben geleid.

\subsubsection{Het meten van cumulatie van belastende omstandigheden}

Het cumulatie-model onderstelt dat het gezamenlijk woorkomen van belastende factoren een groter effect heeft op het voorkomen of ontstaan van ongezondheid en omgekeerd dat de afwezigheid van enige belastende factor een groter positief effect heeft op gezondheid dan de afzonderlijke factoren. Voor cumulatie is het bovendien noodzakelijk dat naarmate er meer belastende kenmerken gezamenlijk voorkomen deze een groter gewicht kriggen dan wanneer er ến kenmerk wel belastend is en andere niet. Dit impliceert dat de gezondheid belastende factoren alle positief of negatief met gezondheid dienen samen te hangen (gelike richting) en voorts dat de cumulatie-index zijn grootste waarde bereikt indien beide factoren aanwezig zijn, een waarde 0 als de een aan-en de ander awezig is en de kleinste waarde heeft indien beide volledig afwezig zijn. De cosinus van de hoek tussen de diagonaal en de resultante van de onathankelijk geachte factoren, voldoet aan al deze voorwaarde. Evenwel, de aan- of afwezigheid van belastende factoren is geen discrete (wel of niet) maar een graduele (meer of minder) meting. Aangezien de mate van aan- of afwezigheid een belangrijk gegeven is en de cosinus van de hoek met de diagonaal maximaal is indien de factoren alle in gelijke mate aanwezig zijn, hoe gering dan ook, is de cosinus van de bovenbeschreven hoek vermeniguuldigd met het produkt van beide belastende factoren, de in het algemene lineaire model gebruikelijke interactie-term. Hierdoor bereikt de cumulatie-index zijin maximale waarde als de factoren alle in gelijke mate sterk aanwezig zijn en zijn minimale waarde indien de belastende omstandigheden alle in gelije mate sterk dan wel geheel afwezig zijn.

Cumulatie van belastende omstandigheden

De wolgende indexen zijn op basis van de hierboven aangegeven methode geconstrueerd. Ze definiëren de aan- of afwezigheid van belastende omstandigheden. Een hoge waarde op de index geeft aan dat beide belastende omstandigheden aanwezig zijn en een lage score dat ze beide afwezig zijn.

Bij sociale klasse gaat het om de cumulatie van woon- en werkomstandigheden, van kentrerken van de woning en de woonomgeving en van de aanwezigheid van dure consumptiegoederen en dure apparatuur voor hobby en vrije tijd.

\section{KLASSE}

cumulatie wan klasse-kenmerken

kwalliteit van de woning en van de werkomstandigheden

kwaliteit van de woning on kwaliteit woonomgeving.

bezil van duurzame consumptiegoederen en wan dure goederen woor de vrije tijd. indexen $(x, y)$

rww $\quad$ kwaliteit woning $n$ kwallitelt werkomstandigheden.

rwwo = kwaliteit woning n kwaliteil woonorngeving

rdureluxe = duurzame hush. artikelen n dure apparatuur voor hobloy an vrije lijd 
Statuskenmerken bestaan uit waardenorientaties die met behulp van geloof en politieke voorkeur kunnen worden geindiceerd en uit leefsijl-kenmerken of riskante gewoontes zoals geindiceerd door het gebruik van tabak en alcohol.

Omdat voor de eerste geen duidelijk cumulatief effect kan worden gedefinieerd, worden deze kenmerken hier niet gebruikt.

Leefstij-kenmerken zoals roken (rook1) en drinken (alc3) en geringe activiteiten in de vrije tijd (actief), kunnen elkaar wel versterken. Omdat zich in de categorie mensen die niet roken en niet (meer) drinken een aantal bevindt dat tabak en alcohol om gezondheidsredenen laat staan, worden twee dummy kenmerken geconstrueerd. Eén die de abstineerders van tabak en alcohol (onthoud) specificeert en een die rokers en zware drinkers definieert (gebruik).

\section{STATUS}

cumblatie van leotstijl-kenmerken

zowel roken als zwaar drinken en

gelbrek an actieve vrije-lijdsbesteding. index $(x, y)$

onthoud(t) $=$ rookt niet $n$ drinkt niet ("actief)

gebruik(t) = rookt wein is zware drinker ("actief)

Omdat de interactie met vrije tijdsbesteding (onthoud" actief en gebruik "actief) in de meeste bestanden niet kan worden gespecificeerd (surveys 1974, 1977 en 1980 CBS; panel 1981 en 1983) wordt alleen naar de effecten van geheelonthouding en van zwaar tabaks- en alcohol-gebruik gekeken. In de twee bestanden waarin het wel mogelijk is de activiteiten in de vrije tijd to specificeren (surveys 1980 SCP en 1983), worden deze afzonderlik geanalyseerd. Uit de eerdere analyses is af te leiden dat vrije tijd meer dan het gebruik van tabak verschillen in gezondheid verklaart.

Elk wan de drie aspecten vam burgerschap, lidmaatschappen, wrijwilligerswerk en gebruik van voorzieningen viel uiteen in drie aspecten die onafhankelijk van elkaar konden worden gedefinieerd. Hun relatief gewicht ontlenen deze aspecten aan de mate waarin sprake is van lidmaatschappen of het ontplooien van activiteiten in verschillende organisaties of waarin er van meer dan éen voorziening gebruik wordt gemaakt. Het cumulatieve effect wordt op dezelfde wijze weergegeven als beschreven voor de kwaliteit van de woning en de werkomgeving.

Leveren de indexen voor cumulatie naast de atzonderlije indexen voor sociale klasse, status of burgerschap een extra bijdrage aan de verklaring van de variatie van gezondheid in de bevolking. dan kan van een cumulatief effect worden gesproken. Indien alleen de cumulatie-indexen een bijdrage leveren aan deze verklaring en de afzonderlijke kenmerken van sociale klasse wegvallen in de verklaring van ongezondheid, dan is er eerder sprake van selectie: mensen met een slechte gezondheid kunnem geen goede huisvesting en gunstige arbeidsomstandigheden verwerven, waerdoor ze eerder in slechte woon- en werksituaties terecht komen. 


\section{BURGERSCHAP}

cumulatie van lidmaatschappen

lid van maatschappelijke organisaties en van culturele organisaties

id van maatschappelijke organisaties en van organisaties voor collectieve vrije tijdsbesteding (sport)

lid van culturele organisaties en van organisaties voor collectieve vrije-tijdsbesteding (sport)

lid van alle drie soorten organisaties

cumulatie van wriwwithigerswerk

actief in het klassieke vrijwilligerswerk en

individuele belangenbehartiging

actief in het klassieke vrijwilligerswerk en

in culturelle organisaties

actief in organisaties voor individuele

belangenbehartiging en culturele organisaties

actief in alle drie de organisaties

cumulatie wan het gebruik van woorzieningen

ontwangt sociaal-medische zorg en

maatschappelijke hulpverlening

ontvangt sociaal-medische zorg en individuele

hulpwerlening

ontwangt maatschappelijke en individuele

hulpwerlening

gebruikt alle deze voorzieningen

\author{
indexen $(x, y)$ \\ ridi2 $=$ ridith rid? \\ midts = Hidin mids \\ rides $=$ rliden rlids \\ rlid123 = ridt $n$ mid2 $n$ rlid3 \\ rury $12=$ rwywil 12 morywile \\ rvrywt3 = rurywilin rvrywil3 \\ ruryw23 = rorywli2 n rurywil 3 \\ ruryw123 = rurywill 1 a purywil2 $n$ rurywil3 \\ rvoor12 = woorz1 a noorz2 \\ rvoor13 $=$ rvoorzl $\cap$ rwoorz3 \\ woor23 $=$ rwoorz2 n woorz3 \\ woor $123=$ woorzi $n$ rvoorz2 $n$ rvoorz 3
}

\section{b Het meten wan sociale inconsistentio}

Van sociale inconsistentie kan worden gesproken wanneer activiteiten worden ontplooid die sterk verschillen in sociale waardering of die atypisch zijn voor de sociale laag waartoe men behoort. Zo worden contact-sporten als worstelen en boksen vooral becefend door mensen uit lagere sociale milieus evenals voetbal en worden hockey, cricket en golf vooral door mensen uit de hogere sociale: lagen beoefend (Sryder, Spreitzer 1983 pp.141-146). Op dezelfde wlize is het publiek dat toneelvoorstellingen en uitvoeringen van klassieke muziek bezoekt eerder afkomstig uit de hogere sociale lagen dan uit de lagere. Van sociale-inconsistentie kan worden gesproken wanneer men zich gedraagt overeenkomstig de voorkeuren die kenmerkend zijn voor andere (hogere of lagere) status-categorieën. Welke activiteiten of kenmerken sociaal 'hoog' of 'laag' zijn (SES-score), kan empirisch worden vastgesteld door per kenmerk of activiteit het gemiddelde van de SES-index te berekenen. De SES-index voor een individu (object-score) is gedefinieerd als de gemiddelde categorie-scores van opleiding, inkomen en sociale groep weke in de niet-parametrische principale componentenanalyse (Homals) per bestand zijn berekend (hoofdstuk 4).

Sociale inconsistentie kan nu worden geoperationaliseerd als de standaardafwijking van de categoriescores van opleiding, inkomen en sociale groep en van de SES-score van de iterns, die de indexen voor tklasse, status en burgerschap definiëren. Indien deze standaarddeviaties 
relatief gering zin, is de sociale consistentie hoog en met hel groter worden van deze standearddeviaties neemt de sociale inconsistentie toe.

Bij de berekening van de scciale inconsistentie wordi uitgegaan van de afzonderlijke onderdelen waaruit de indexen voor klasise, status en burgerschap zijn opgebouwd. lemands werk is sociaal inconsistent als de SES-scores van de kenmerken van zijn werkomstandigheden sterk variëren; evenzo is iemands vrijetijdsbesteding inconsistent als sommige activiteiten een hoge SES-score hebben en ander juist een lage. Klasse-inconsistentie bestaat wanneer de gemiddelde SES-Scores voor de woonomgeving, de kwaliteit van de huisvesting en van het werken en de gemiddelde SES-scores woor bezit sterk variëren. Stalus-inconsistentie is gedefinieerd als de standaardatwijking van de gemiddelde SES-scores voor politieke overtuiging, geloofsovertuiging, riskante gewoonten en vrije-tijdsbesteding. Sociale inconsistenties in burgerschap zijn gedefinieerd als de standaardafwijking van de gemiddelde SES-scores op de items voor lidmaatschappen, woor vrijwilligerswerk en voor het gebruik van woorzieningen. Deze operationalisering van sociale inconsistentie is onafhankelijk van de cumulatie-indexen. Beide modellen kunnen derhalve tegelijk worden getoetst.

\section{c Toetsing}

Met behulp van regressieanalyse wordt, op de in hoofdstuk 3 uiteengezette methode, getoetst. of toevoeging van interactie-termen (indexen voor cumulatie en voor sociale inconsistentie) de verklaring van gezondheid op basis van de afzonderlijke kenmerken van klasse, status en burgerschap verbetert. Vervolgens wordt nagegaan of binnen de onderscheiden modellen bepaalde interacties bij uitstek verantwoordelijk zijn voor deze bijadrage. Indien beide modellen, zowel cumulatie als sociale inconsistentie verantwoordelijk zijn voor de gevonden effecten, wordt niet gepoogd om thet relatieve belang van het ene model boven het andere vast te stellen, maar wordt nagegaan welke indexen in beide modellen gezamenlijk in een bellangrijke mate aan de verklaring van verschillen in gezondheid bijdragen.

Blijken de effecten van de kenmerken van klasse, status en burgerschap teniet te worden gedaan door invoering van de indexen voor cumulatie of sociale inconsistentie dan berust het effect van eerder genoemde kenmerken slechts op hun samenhang met cumulatie of sociale inconsistentie. In dat geval zijn dat de enige verklaringen voor verschillen in gezondheid.

Evenals in de eerdere analyses is nagegaan of de uitbreiding van het SEGV-model met cumulatieof inconsistentie-termen de relatie fussen de SES-index en gezondheid beinvloedt. Indien door de invoring van de cumulatie- en inconsistentie-indexen de bijdrage van de SES-index aan de verklaring van wariatie in gezondheid in de bevolking verdwijnt, dan geven deze indexen de mechanismen weer die tot sociaal-economische gazondheidsverschillen leiden. Dit wordt nagegaan door te toetsen of de $\beta$ van de SES-index met gezondheid beduidend van 0 verschilt $(p<0.10)$ na invoering van de cumulatie- en inconsistentie indexen.

Het kan ook zijn dat invoering van de indexen de relatie tussen de SES-index en gezondheid versterkt. In dat geval zou sociale inconsistentie of cumulatie van adversieve levensomstandigheden de gezondheid beschermen.

\subsection{Resultaten}

De Mehalonobis afstanden van de respondenten tot elkaar werden berekend voor de cumulatieen consistentiemindexen. Deze zlin vergeleken met de afstanden die in eerdere analyses werden gevonden. De samenhang (r) tussen beide afstandsmaten bedroeg 0.78 (range 0.67-0.85); over het algemeen zullen daarom in beide analyses dezelfde respondenten van dealname aan de analyse worden uitgesloten, respectievelijk zullen de analyses voor het cumulatie-en sociale inconsistentie-model op dezelfde respondenten kunnen worden uitgevoerd als in de analyses 
voor het additieve model. In de bijlagen wordt een wolledig overzicht van de bevindingen gegeven Tabel 13 tot en met Tabel18.

\subsubsection{Het cumulatie-model}

\section{a De cumulatie van kenmerken van klasse}

Cumulatie van klasse-kenmerken, met name van adversieve levensomstandigheden, verklaart werschillen in gezondheid niet $\left(0.001<d\left(R^{2}\right)<0.004\right)$. Dit geldt zowel voor het oordeel over de eigen gezondheid, de ervaren gezondheid als de aanwezigheid wan chronische aandoeningen (Tabel 13). De negatieve regressiecoëficiënt in het survey 1980 CBS kan worden geacht op toeval te berusten ( $\beta_{\text {WOONWAK, OEG }}=-0.13$, (Tabel 14)). In geen van de andere bestanden wordt een verband in deze richting gevonden, ook niet voor de overige indicatoren voor gezondheid. Er is derhalve geen reden om aan te nemen dat de kwaliteit van woon-en werkomstandigheden elkaars invloed op gezondheid versterken of verzwakken. Evenmin is er een aanwijzing dat de kwaliteit van de buurt en van de woning gezamenlijk een groter effect op gezondheid heeft dan elk van deze afzonderlik.

Het bezit van duurzame consumptiegoederen alsmede van dure apparaten voor hobby en vrije thijd, gaat samen met een goede gezondheid. De stabiliteit van deze bevinding over de bestanden is woor het oordeel over de eigen gezondheid niet groot $\left(-0.18<\beta_{\text {BEzT OEG }}<0.26\right.$; 2 negatief, 3 positief). Voor de ervaren gezondheid is de stabiliteit duidelijk groter $\left(-0.36<\beta_{\text {BEziT,VoEG }}<0.00\right.$; 4 negatief), dat wil zeggen: hoe minder bezit, des te meer klachten (Tabel 14). Mensen met veel bezit hebben doorgaans geen chronische aandoeningen (survey $1980 \mathrm{CBS}$ ) maar in de overige bestanden is deze samenhang juist positief, zij het niet significant. $\left(-2,00<b_{\text {Bezir,chr zigh }}<0.49\right.$ (Tabel 15)).

\section{b De cumulatie van sociale status en leetstijl}

De cumulatie van status-kenmerken draagt 0.1 tot $2.4 \%$ bij aan de verklaring van verschillen in gezondheid (Tabel 13). Actieve sportbeoefening en het deeinemen aan culturele activiteiten dragen slechts in én bestand (survey 1974: $\beta_{\text {SPRTCL,OEG }}=0.21 ; \beta_{\text {SFRTCLT VOEG }}=-0.20$ ) duidelijk bij a an een goede gezondheid. In de overige bestanden is de aard van deze bijdrage wel dezelfde, maar is de omvang van deze bijdrage zeer gering (Tabel 14).

Evenmin is er een duidelijke en consistente samenhang tussen het laten statan van alcohol on tabakswaren en gezondheid. In drie bestanden wordt een positief verband gevonden tussen het laten staan van alcohol en tabak en gezondheid en in twee een negatief verband (Tabel 14). Hoewel de bevindingen binnen de bestanden consistent zijn, zijn ze niet stabiel over de verschillende bestanden. De $\beta$ 's die duidelijk van nul verschillen wijzen op de tendens dat mensen die geen alcohol en tabak gebruiken wat gezonder zijn dan mensen die wel roken of drinken. Evenwel laten meer chronisch zieken alcohol en tabak staan dan normaal gezonden $\left(-2.88<\beta_{\text {ONTHOWD }}<\right.$ 0.10 (Tabel 15)).

Ook de relatie tussen roken en zwaar drinken en gezondheid is noch binnen noch tussen de bestanden consistent. Op basis van het teken van de p-coefficiënten moet worden gesteld dat roken en zwaar drinken de gezondheid noch schaadt noch baat (Tabel 14) en dat de combinatie wan roken en zwaar drinken minder voorkomt onder chronisch zieken dan in de normaal gezonde bevolking ( $-0.99<\beta<-0.08 ; b=-0.45$ (survey 1980 SCP (Tabel 15)).

in twee bestanden was het mogelijk rook-en drink-gedrag te analyseren in samenhang met de wrije-tijdsbesteding. In een bestand (survey $1980 \mathrm{SCP}$ ) is er een duidellike relatie tussen deze leefwijze en gezondheid. In het andere bestand (survey 1983) is geen van deze relaties duidielijk aantoonbaar en is de richting soms omgekeerd. Mensen die roken, zwaar drinken en niet actief zijn in hun vrije tijd, zijn over het geheel genomen ongezonder dan mensen die mensen die deze 


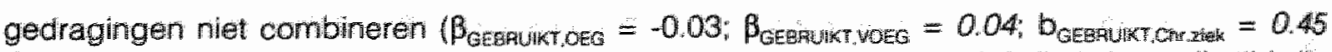
(Tabel 14:Tabel 15)). Mensen die niet roken, alcohol laten staan en actief zijn in hun vrije tijd zijn: over het geheel genomen gezonder dan de owerige leden van de bevolking ( $\beta_{\text {ONthovor. OEG }}=0.05$;

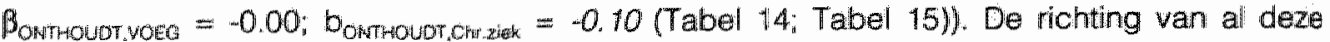
coëflicienten wordt wolledig bepaald door de inactieve respectievelijk actieve leefstijl en niet door het roken en drinken.

\section{c De cumulatie wan kenmerken van burgerschap}

De cumulatie van burgerschapskenmerken draagt van de hier gepresenteerde modellen (gemiddelde bijdrage 1 lasse 0.002; Status 0.005: Burgerschap 0.011) het meest bil aan de verklaring van gezondheidswerschillen in de bevolking $\left(0.003<8 \mathrm{R}^{2}<0.022\right)$. Deze bijdrage is slechts ten dele toe te schrijven aan het groter aantal gespecificeerde effecten (12 termen versus 3 bil kilasse-respectievelijk status-kenmerken). De gemiddelde bijdrage per cumulatie-term is groter dan bij de kenmerken wan sociale klasse (Tabel 13).

De effecten van cumulatie van lidmaatschappen, vrijwilligerswerk of het gebruik van woorzieningen is binnen de bestanden consistent "maar tussen de bestanden niet stabiel. Over het geheel genomen lijkt alleen het lidmaatschap van sport en culturele organisaties een bijdrage te leveren aan het gezondheidsoordeel $\left(\beta_{\text {RLIDA3.OEG }}=0.21\right.$ en 0.18 in respectievelijk het survey $1980 \mathrm{SCP}$ en het survey 1983 (Tabel 14)). Deze relatie is voor de overige indicatoren voor gezondheid afwezig. In het survey 1974 komen de lidmaatschappen van deze organisaties vaker voor bij mensen die door lichamelijke aandoeningen belemmerd worden in hun dagelijks leven.

Het doen van allerlei vrijwilligerswerk heeft geen duidelijk relatie met gezondheid. Zowel tussen de besitanden als binnen de bestanden is geen consistent beeld te wormen. Het ontplooien van activiteiten in zowel beroeps-, als kerkelijke en culturele organisaties is woorbehouden aan mensen

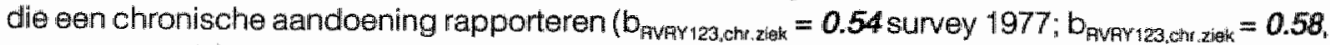
survey 1980 SCP (Tabel 15)) of zich niet gezond achten $\left(\beta_{\text {Rvartza.oeg }}=0.12\right.$ survey 1980 SCP), maar in de overige bestanden is deze relatie niet aantoonbaar of lijkt deze eerder omgekeerd $\left(\beta_{\text {fivfrizavoEg }}=-0.17\right.$, survey 1983) (Tabel 14). Er is derhalve geen duidelijke relatie aantoonbaar tussen het doen van vrijwilligerswerk in verschillende organisaties en gezondheid.

De samenhang tussen het gebruik van sociaal-medische diensten en diensten voor maatschappelijke of individuele hulpverlening zijin zowel tussen de bestanden als binnen de bestanden inconsistent. Mensen die gebruik maken van zówel maatschappelijke (GSD, algemeen of bedriffsmaatschappelijk werk) als individuele hulpwerlening (sociale raadslieden, geesitellike gezondheidszorg) achten zich gezonder $\left(\beta_{\text {pwookz3.0EG }}=0.28\right.$, survey 1974) en hebben minder

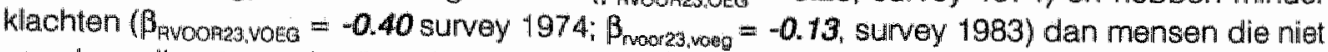
van deze diensten gebruik maken (Tabel 14). Er bestaat een positieve samenhang tussen het

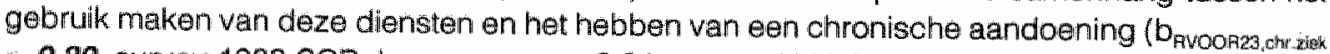
$=0.30$. survey $1980 \mathrm{SCP} ; b_{\text {Rwoonzachr.zialk }}=0.24$ survey $\| 983$ (Tabel15)).

De samenhang tussen het gebruk van alle voorzieningen en gezondheid is zowel tussen als binnen de bestanden niet consistent, zodat deze hier niet verder wordt besproken. De bevindingen wijzen erop dal mensen die gebruik maken van voorzieningen voor zowell individuele als maatschappelike hulpverlening vaak een chronische aandoening hebben en zlch welbevinden.

\section{d Hot cumulatie-model: samenvatting}

Over het geheel genomen kan niet worden gesteld dat gezondheid bedreigende factoren op dezelfde levensterreinen elkaar zonder meer versterken. Er is geen steun te vinden voor de meest woor de hand liggende onderstellingen, namelijk dat slechte woon-en werkomstandigheden enerzijds en roken en zwaar drinken anderzijds de gezondheid aanmerkelijk meer in gevaar 
brengen dan wanneer deze condities niet of slechts gedeeltelijk aanwezig ziln. Ook cumulatio van bezit heett slechts een zwakke relatie met gezondheid.

Actieve sport-en cultuurbeoefening gaan samen met een goede gezondheid. Mensen die geen tabak en alcohol gebruiken zijn waker chronisch zlek en voelen zich gezonder dan mensen die deze genotmiddelen wel gebruiken. Mensen die zowel roken als zwaar drinken beoordelen hun gezondheid niet slechter en hebben niet meer klachten dan mensen die deze genotmiddelen niet of met mate gebruiken. Wanneer veel drinken en roken al negatieve effecten op gezondheid hebben, worden deze door een actieve vrijetijdsbesteding gecompenseerd, terwijh het laten staan van alcohol en tabak niet compenseert voor inactiviteit: mensen die niet roken, niet drinken en er cok niet in thun vrije tijd op uit trekken hebben een slechtere gezondheid dan geheelonthouders die wel een actiewe wrijetijdsbesteding kennen.

Het lidmaatschap van sport en culturele organisaties lijkt samen te gaan met een goede gezondheid. Er is geen duidelijke relatie tussen het doen van vrijwilligerswerk en gezondheid, hoewel het mogelijk is dat mensen met een aandoening vaker dan anderen op verschillend gebied vijwilligerswerk doen. Mensein die zowel contacten hebben met het maatschappelijk werk, de gemeentelijke sociale dienst (uitkering), een sociale raadsman of vrouw of wetswinkel zijn meer dan op basis van hun overige kenmerken is te verwachten chronisch ziek of gehandicapt en voelen zich gezonder dan mensen met die niet van al deze diensten gebruik maken.

Deze bevindingen laten zien dat verschillen in gezondheid in de bevolking niet zozeer door cumulatie van adversieve levensomstandigheden worden veroorzaakt, maar dat ziekte of handicap gevolgen hebben voor leefstijl en maatschappelijke participatie. Door chronische aandoeningen laten mensen alcohol en tabak eerder staan. Het kunnen ondernemen van activiteiten, maakt dat ziij zich desondanks gezonder voelen dan op basis van al hun overige kenmerken mag worden verwacht. Dit geldt cok voor hen die roken en alcohol in rume mate gebruiken.

Met name deze laatste bevindingen wijzen niet zozeer op een causaal mechanisme dat ten grandslag ligt aan het cumulatie-model maar eerder op effecten van selectie: abstinentie van alcohol en tabak is dian vooral een uiting van ziekte en de activiteiten op kerkelijk of politiek gebied een manier waarop een zinvolle tijdsbesteding wordt gevonden. Toetsing van zulk een causaal cumulatiemodel kan slechts plaats winden in longitudinaal onderzoek. De hier gepresenteerde bevindingen wijzen er slechts op dat een actieve tijdsbesteding de effecten van adversieve levensomstandigheden sterk modificeert.

\subsubsection{Het sociale inconsistentie-model}

Voor het inconsistentie model is in het geanalyseerde materiaal enige ondersteuning te vinden (OEG $0.1 \ldots 1.6 \%$, VOEG $1.0 \ldots 1.7 \%$, Chron. Ziek 0.5 ... 1.7\% (Tabel 16)). Ten opzichte van het cumulatie-model heeft dit model een extra term omdat ook inconsistenties in de SES-index zelf kunnen worden achterhaald (verschillen in opleiding, inkomen en bercep). Deze hebben een negatieve invloed op het oordeel over de gezondheid $\left(-0.11<\beta_{0 E G}<0.07\right)$ en op de ervaren gezondheid $\left(-0.01<\beta_{\text {vofG }}<0.05\right.$ (Tabel17)). Met chronische aandoeningen bestaat zulk een relatie niet $(-0.07<b<0.11 ; 4$ negatief, 3 positief (Tabel 18)).

Sociale inconsistentie in klasse-kenmerken verbeteren in geringe mate de verklaring van verschillen in gezondheid in de bevolking (.001<8 $\mathrm{R}^{2}<0.002$ (Tabel 16)). De verklaring wordt vooral gedragen door inconsistenties in de kwaliteitsaspecten van de woning die een positieve invloed hebben op de gezondheid $\left(0.09<\beta_{\text {woonses.oeg }}<0.05 ;-0.06<\beta_{\text {woonses voes }}<-0.01\right.$ (Tabel 17); $-0.11<$ $b_{\text {woonses, CHa.zIEK }}<0.00$ (Tabel 18)) Mensen die in een koud en tochtig eengezinshuis wonen dat hun eigendom is, hebben een betere gezondheid dan mensen die een koude en tocktige huuretage bewonen. Het wonen in een buurt met sociaal consistente kenmerken lijkt samen te gaan met 
een lets beter oordeel over de gezondheid (in alle 4 bestanden een zwakke negatieve $\beta$ ) maar ook met meer ervaren klachten; met chronische aandoeningen hebben inconsistenties. in buurkenmerken geen relatile.

Er is een aanwijzing dat inconsistenties in bezit samengaan met een als slecht ervaren gezondheid $\left(-0.02<\beta_{\text {Bratitres votG }}<0.05\right.$ (Tabel 17))

Wanneer alle inconsistenties in de kenmerken van sociale klasse tezamen worden genomen, blijkt een grote sociale inconsistentie in deze kenmerken samen te gaan met ongezondheid (zwak negatieve samenhang met het oordeel over de eigen gezondheid ( $\beta$ ) in 4 bestanden, een als slecht ervaren gezondheid $\left(-0.03<\beta_{\text {FcLssiso voeg }}<0.09\right.$ (Tabell7)) en een verhoogde kans op de aanwezigheid van chronische aandoeningen $\left(-0.14<b_{\text {Acussiso.CHR.ziek }}<0.22\right.$ (Tabel 18)).

\section{b Sociale inconsistenties in kenmerken van leefstijl en status}

Met betrekking tot inconsistenties in sociale status is in het geanalyseerde materiaal enige ondersteuning te vinden waar het het oordeel over de eigen gezondheid betreft, (OEG: 0.000 $\left.<\delta\left(R^{2}\right)<0.010\right)$ en de ervaren gezondheid $\left(0.000<\delta\left(R^{2}\right)<0.009\right)$ maar niet voor de aanwezigheid van chronische aandoeningen (Tabel 16).

Naast de inconsisterities in de sociale waardering van roken, drinken en wrijetijdsbesteding kunnen ook inconsistenties in de waardering voor het geloof en de politieke overtuiging in de analyse worden betrokken. Inconsistenties in leefstijl bestaan wanneer well wordt gerookt maar geen alcoho: wordt gedronken. Inconsistenties in politiek en geloof zijn aanwezig als bijwoorbeeld mensen lid Zijn van een kerkgenootschap maar stemmen op een (Klein) linkse of liberale partij; consistentie bestaat als leden van kleine protestantse kerkgenootschappen op de kleine confessionele partijen stemmen.

Inconsistenties in de vrijetijdsbesteding verbeteren enigszins het oordeel over de gezondheid $\left(-0.02<\beta_{\mathrm{AVTES} \mathrm{OEG}}<0.11\right)$ en gaan gepaard met een als beter ervaren gezondheid $(-0.13<$ $\beta_{\mathrm{PVTSESVOEG}}<0.03$ ) (Tabel 17). In drie van de vier bestanden is er een negatieve samenhang tussen inconsistenties in de vrijetijdsbesteding en de aanwezigheid van chronische aandoeningen (Tabel 18). Mensen die meer verschillende activiteiten ondernemen hebben derhalve een betere gezondheid dan mensen die sociaal-homogene activiteiten of geen activiteiten ondernemen. Sociale inconsistenties in rook-en drinkgedrag tonen geen duidelijke relatie met het oordeel over en de ervaring van de eigen gezondheid. Wel lijken mensen die wel drinken en niet roken (sociaal consistent) vaker eern chronische aandoening te hebben dan mensen die roken en geen alcohol drinken (sociaal inconsistent).

Sociele inconsistentles in geloof en politieke overtuiging leveren binnen de bestanden wel consistente resultaten op, maar tussen de bestanden niet. Het lijkt alsof deze sociale inconsistentie de subjectieve gezondheid positief beînvloedt $\left(-0.04<\beta_{\text {FLTKGLFEG }}<0.16,-0.17<\beta_{\text {FLTKLFWOEG }}<\right.$ Q.11 (Tabel 17$)$ ), maar geen invloed heeft op de aanwezigheid van chronische aandoeningen (Tabel 18).

Zowel tussen als bilnen de bestanden is de relatie tussen status-inconsistentie (de inconsistentie van de onderscheiden kenmerken van status) niet erg stabiel. Voor zover de samenhang tussen sociale inconsistentie in statusskenmerken en gezondheid duidelik van o verschilt, is deze, in tegenstelling tot de verwachting. positief gericht.

\section{c Sociale inconsistentio in kenmerken van burgerschap}

Sociale inconsistenties in kenmerken van burgerschap beirmoeden văn de hier onderzochte sociale inconsistenties gezondheid het meest (OEG: $0.000<\delta\left(\mathrm{R}^{2}\right)<0.009$ VOEG: $0.000<\delta\left(\mathrm{R}^{2}\right)<0.018$; Chr. ziek: $0.003<8 \mathrm{~F}^{2}<0.008$ (Tabel 16))

Sociale inconsistentie in lidmaatschap van verenigingen, zoals de combinatie van lidmaatschappen van een politieke partij, een sportvereniging en van een bibliotherk, gaal samen met een goed 
oordeel over de eigen gezondheid $(.02<\beta<0.10)$, een goede ervaren gezondheid $(-0.05<\beta$ $<-0.01$ ) (Tabel 17) en onder mensen met deze combinatie van lidmaatschappen komen relatief weinig chronisch zieken of gehandicapten voor $(-0.29<b<0.03$ (Tabel 18)).

Met uitzondering van het oordeel over de gezondheid waar voor alle vier bestanden waarin deze kenmerken zijn opgenomen, positieve, maar niet duidelijk van 0 verschillende $\beta$ 's worden gevonden en het bestand survey 1974 warar inconsistenties in vriwilligerswerk samengaan met de afwezigheid van chronische aandoeningen $(b=-0.32$ (Tabel 18)), is de samenhang van sociale inconsistenties in vrijwilligerswerk (actiegroepen, beroepsorganisaties en sportverenigingen) met indicatoren voor gezondheid tussen en binnen de bestanden niet stabiel.

Sociale inconsistenties in het gebrik van scciale woorzieningen, gebruik van zowel de gemeentelike sociale dienst, een sociaal raadsman, als gezinszorg en wijkverpleging, hangen het duidelijkst van alle overige kenmerken vain burgerschap negatief samen met gezondheid. Daarbij geldt dat hoe groter de sociale inconsistentie is, hoe slechter de gezondheid (OEG: $-0.13<\beta<0.10$; VOEG: $0.06<\beta<0.23$ (Tabel 17); Chr. ziek: $0.03<\mathrm{b}<0.32$ (Tabel18)).

Worden de sociale inconsistenties in lidmaatschap, vrijwilligerswerk en het gebruik van woorzieningen bij elkaar genomen, dan is er geen duidelike relatie met gezondheid aan te wijzen.

\section{d Het sociale inconsistentie model: samervatting}

Sociale inconsistenties, het uiteenlopen van de maatschappelijke waardlering voor iemands kenmerken van klasse, status en burgerschap hebben een duidelijke invloed op gezondheid. Anders dan ondersteld, hebben alleen sociale inconsistenties in de kenmerken van de SES-index, het gebruik van maatschappelijke voorzieningen en wellicht van buurtkenmerken een negatief effect op gezondheid. Inconsistenties in de besteding van vrije tijd, in woonomstandigheden, lidmaatschappen van verschillende organisaties en wellicht ook van vrijwilligerswerk hebben een positief effect op gezondheid.

In zijn ruwe vorm moet het inconsistentie-model worden verworpen omdat het in de eerder gepresenteerde vorm te grove uitspraken doet. Het is evenwel de vraag of het model kan worden aangepast.

De hier beschreven bevindingen zijn in zoverre stabjel, dat sociale inconsistenties, voor zover ze zelf zijin gekozen, zoals bij sociale discrepantie in politieke overtuiging en geloof en bij lidmaatschappen en vrijwilligerswerk, een positieve invloed op gezondheid hebben, terwijl die welke door omstandigheden worden opgedrongen, zoals bij de het uilteenlopen van onderwijs, inkomen en beroepsstatus en bij de noadzaak tot het gebruik van maatschappelijke voorzieningen een negatieve relatie met gezondheid hebben.

De hier gepresenteerde gegevens maken het aannemelikk dat inconsistenties waar men geen greep op heeft de gezondheid negatief beinvloeden, maar dat die welke men zelf kiest juist een positief effect op gezondheid hebben. Dit is in overeenstemming met Antonovsky's 'sense of coherence' en met theorieën over 'mastery', waarin individuen die zelf hur lot kunnen bepalen gezonder worderi geacht en minder blootstaan aan chronische stress dan mensen die geen greep op hun leven krijgen. De op het eerste gezicht wat ongewone bevinding dat kou en tocht hijen in een huurhuis ongezonder is dan in een huis dat men zell bezit, sluit hierbij aan: het is een zelf gekozen vorm van "lijden" die alleen door de eigenaar kan worden opgelost.

Ook de bevinding dat sociale inconsistenties in politieke overtuiging en geloof, in het gebruik van alcohol en tabak en van lidmaatschappen een positief effect op gezondheid hebben siuiten aan bij de idee van "mastery": men is in staat keuzes te maken of in modern jargon 'bewust te leven'. Het positieve effect van sociale discrepanties in lidmaatschappen van verenigingen verhoudt zich woorts goed met theorieen over 'marginale figuren' en het belang van zwakke bindingen (Granovetter 1974). Mensen die met verschillende sociale cirkels contacten onderhouden kunnen door hun kennis van deze cirkels als belangrijke brug en als stuurders van informatie optreden. 
waardoor ze grote invloed kunnen hebben op het gedrag van mensen binnen deze cirkels. Daame vinden ze een worm van 'mastery'.

Inconsistenties in het voorzieningenniveau liken goed te kunnen worden verklaard doordat met name deze discrepanties bestaan bij het gebruik maken van voorzieningen voor individuele en maatschappelijke hulp. Indien men van deze voorzieningen gebruik moet maken is de 'mastery" gering. Op dezelide wijze kan worden verwacht dat mensen bij wie de kenmerken voor sociaaleconomische laag uiteenlopen (discrepanties ussen inkomen, opleiding en beroep) zich ongezonder voelen dan mensen bij wie dat niet het geval is.

\subsection{Discussie: Cumulatie en Consistentie}

Uitgaande van de onderstelling dat blootstelling aan adversieve levensomstandigheden een negatief effect op gezzondheld zou hebben; is onderzocht of interacties tussen de onderscheiden kenmerken van respectievelijk klasse, status en burgerschap een betere verklaring van gezondheid geven dan modellen waarin de indicatoren van deze begrippen afzonderlijk zijn ingevoerd. De verhoogde blootstelling aan adversieve levensomstandigheden zou schadelijker voor de gezondheid zijn dan blootstelling aan slechts eén factor. Het zijn blootgesteld aan zowel slechte werk- als woonomstandigheden of roken én zwaar drinken bijvoorbeeld, wordt geacht schadelijker voor de gezondheid te zijn dan het hebben van slecht werk of slechte huisvesting alleen of het roken zonder ook zwaar te drinken. Naast deze cumulatie-hypothese werd een ander verklaringsmodel gezet dat de verklaring voor verschillen in gezondheid in de bevolking zoekt in de verschillen in sociale waardering van de onderscheiden kenmerken van klasse, status en burgerschap: ondersteld werd dat naarmate deze meer verschillend werden gewaardeerd, de 'sense of coherence' of de 'mastery' zou afmemen, hetgeen zou leiden tot chronische stress welke het atweermechanisme ontregelt.

Beide modellen blijken ongeveer $1 \%$ extra variantie te verklaren. Hoewel dit een zeer bescheiden percentage is, mag het miettemin niet worden veronachtzaamd. Immers, het gaat hier om steekproeven uit de Nederlandse bevolking. Bij een verbetering van de schatting van het aantal chronisch zieken met $1 \%$ gaat het om $1 \%$ van de Nederlandse hoofden van huishoudens wan 18 jaar en ouder, dat wil zeggen om $1 \%$ van de 5.5 a 6 miljoen hoofden van huishoudens die Nederland kent, ergo over 55 a 60 duizend mensen met een chronische aandoening.

De cumulatie van klasse-kenmerken, die het duidelijkst een relatie hebben met de blootstelling aan negatieve fysieke kenmerken, blijkt niet of neuwelijks bij te dragen aan de verbeterde schattingen van de gezondheidsmaten. Het is vooral de cumulatie van status- en met name burgerschapskenmerken die verantwoordelijk is voor de verbeterde schattingen. Zoals bekend uit de literatuur en uit de eerdere analyses zijn mensen die niet drinken, doorgaans wat ongezonder dan mensen die wel alcohol gebruiken. Om die reden is zowel voor mensen die niet roken en niet drinken en voor mensen die wel roken en zwaar drinken nagegaan of deze leefstijlkenmerken van invloed zijn op de gezondheid. Als dit al het geval is, blijken mensen die niet roken en ook niet dririken iets gezonder en blijken, in overeenstemming met het bovenstaande, chronisch zleken zich minder vaak te buiten gaan aan tabak en alcohol dan nomaal gezonden.

Ook blijken mensen die zowel actief zijn op cultureel gebied als in de sport gezonder te zijn dan zij die dat niet doen. Dit effect wordt ook gevonden voor mensen die lid zijn van verenigingen
die op deze terreinen actief zijn.

Deze bevindingen geven geen ondersteuning aan de onderstelling die ten grondslag ligt aan het cumulatie-model, namelijk dat blootstelling aan verschillende adversieve levensomstandigheden de ge:ondheid meer schaadt dan mag worden verwacht op basis van blootstelling aan de afzonderlijke factoren. Eerder lijkt er sprake van selectie, namelijk dat mensen die sporten en culturelle belangstelling hebben en hum vrije tijd actief besteden, ongeacht hun overige kenmerken, 
gezonder zijn dan mensen die dat niet kunnen of niet doen. In transversaal onderzoek, zoals het onderhavige, is de tijdsduur van blootstelling niet gemeten en kan derhalve het bestaan van cumblatie-effecten niet worden aangetoond. Niettemin is geprobeerd cumulatie-effecten te meten andat via de vragen in survey-onderzoek een bestaande situatie wordt weergegeven. Indien cumulatie van effecten zou bestaan moet kunnen worden aangetoond dat mensen die aan meer dan éen factor die een risica voor de gezondheid inhoudt, zijn blootgesteld, ongezonder zijn dan mensen bij wie dat niet het geval is. De hier gepresenteerde bevindingen wijzen niet in die richting tenzij de geaccumuleerde negatieve effecten op de gezondheid zich zo snel manifesteren dat mensen die aan meer dan éen rilisicofactor zijn blootgesteld daarvan onmid delijk zodanige sociale en gezondheidsschade ondervinden dat zil niet meer in aanmerking komen om mee te doen aan enquêtes van het survey- en panelonderzoek of dat weigeren. Dit lijkt evenwel niel waarschijnlik in de Nederlandse situatie. Als er al sprake is van selectie, is het dat mensen die actief kunnen zijn, kumnen doen en laten wat zij zelf willen omdat zij niet door chronische ziekten of aandoeningen worden belemmerd, zich gezonder voelen dan mensen die dat niet (meer) kunnen. Dat zou betekenen dat het ondernemen van activiteiten tegen ongezondheid beschermt, hetgeen in overeenstemming is met het mechanisme dat ten grondslag ligt aan het model van sociale consistentie.

Ook voor sociale consistentie blijkt het gepostuleerde model te grof. Niet alle sociale inconsistenties zoals gemeten met behulp van de gemiddelde score op de SES-index van respondenten in ëen antwoordicategorie, blijken een negatieve relatie met gezondheid te vertonen. Dat is alleen het geval bij inconsistenties in opleiding, inkomen en sociale groep en in die kenmerken van sociale klasse en burgerschap waarvoor mag worden aangenomen dat ze niet berusten op eigen keuzes. Deze bevinding lijkt een ondersteuning voor de idee dat de relatie tussen sociale inconsistenties en gezondheid afhankelijk is van de mate waarin deze inconsistenties een uiting zijn van een gebrekkige controle over het eigen leven (mastery) of de onmogelijkheid het leven als én geheel te zien (sense of coherence). Naarmate iemand daartoe minder in staat is, wat afhankelijk is van zijn of haar positie in de samenleving, is de kans op ongezondheid groter. 


\section{SAMENVATTING VAN DE BELANGRIJKSTE UITKOMSTEN}

Na een korte beschrijuing van de centrale vraagstelling en van de gekozen opzet - data en analysemethoden - van dit onderzoek, worden in dit hoofdstuk de bevindingen van de analyses samengevat, geëvalueerd en afgezet tegen de geformuleerde hypothesen. Aansluitend worden de beperkingen wan de gebruikte methode van onderzoek besproken en de betrouwbaarheid en geldigheid van de resultaten geëvalueerd.

\subsection{Vraagstelling en concepten}

\subsection{Vaagstelling}

Sociaal-economische gezondheidsverschillen lijken van alle tijden te zijn. Tot ver terug in de West-Europese geschiedenis zijn er aanwijzingen te vinden voor verschillen in sterftekansen tussen armen en rijken. Konden die nog worden toegeschreven aan de grote, met de standenof Klassenstructuur van de samenleving samenhangende verschillen in leefomstandigheden. moeilijker is te verklaren waarom zelfs onder de hedendaagse condities van algemeen actief en passief kiesrecht, geavanceerde en toegankelijke medische zorg, relatief hoog opleidingsniveau, gespreide welvaart, sociale zekerheidsstelsels, nog steeds mensen in de lagere sociale strata een hogere kans op een slechte gezondheid en vroegtijdige sterfte hebben dan mensen in de hogere strata. Ondanks de aandacht die de afgelopen eeuw door artsen, politieke activisten, epidemiologen en andere onderzoekers aan deze gezondheidswerschillen is besteed, is nog geen algemeen geaccepteerde verklaring voor deze verschillen voorhanden. Naast elkaar en vaak ook tegenover elkaar bestaan uiteenlopende hypothesen en zienswijzen, die soms hun aanhang meer aan politiek-ideologische verwantschap dan aan empirische fundering hebben te danken. Behalve aan toegeschreven, door het individu niet te veranderen, standskenmerken als leettijd, gesiacht of ethiciteit, wordt de ongelijkheid van de sociale klassen voor de dood geweten aan verschillen in blootstelling aan kwalike leefomstandigheden (slechte huisvesting, werkomstandigheden, armoede en gebrek), aar verschillen in leefwijzen, houdingen en gedragingen, waardoor mensen verschillen in de mate waarin ze zich blootstellen aan risicofactoren en een ongezonde leefstijl of aan verschillen in de mate waarin mensen beschikken over ondersteunende sociale contacten en deelhebben aain de samenleving. De verklaring van gezondheidsverschillen tussen de sociale lagen impliceert derhalve een ongelifke verdeling van gezondheid bedreigende factoren over de sociale lagen, waardoor op individueel niveau de kansem op leven in goede gezondheid ongelijk zijn. Op het niveau van de samenleving is de verklaring woor sociaal-economische gezondheidsverschillen gelegen in de ongelijke verdeling van gezondheid bedreigende factoren. Op individueel niveau geldt de wraag naar de aanwezigheid van én of meer van deze factoren als oorzaak van betere of slechtere gezondheid. De vraag is ook of op individueel niveau deze factoren elkaar versterken (cumulatie) zodat blootstelling aan meer dan een gezondheidsrisico de gezondheid meer schaadt dan te verwachten is op basis van blootstelling aan de afzonderlijke factoren. Immers, naarmate men meer adversieve levenservaringen heeft of in vele situaties is blootgesteld aan 
toxiscthe stoffen of andere fysiek belastende factoren, heeft het lichaam minder mogellikheid daarvan te herstellen. Deze gezondheidsrisico's zouden dan elkaars effect kunnen versterken. Onder de aannames dat mensen niet erg veel verhuizen en dat werkomstandigheden wooral met het beroep en de aard van de werkzaamheden hebben te maken en daarom voor elke respondent vrij stabiel zullen zijn, is het in transversaal onderzoek te verwachten dat deze elkaar versterkende negatieve gezondheidseffecten aantoonbaar zijn.

Evenzo kan de vraag worden gesteld of inconsistenties in kenmerken van klasse, status en burgerschap, met chronische stress als de waarschijnlijke mediator, een nadelig effect op gezondheid hebben. Naarmate men minder in staat is zijn omgeving te veranderen of er zich aan te onttrekken (klasse), deze minder kan beheersen of begrijpen (status), noch van anderen weinig hulp kan verwachten en voor zijn inkomen athankelijk is van de staat (burgerschap). leeft men meer in 'distress" "wat op de lange duur kan leiden tot problemen met het immunologisch apparaat en daardoor tot nadelige effecten op de geestelijke en lichamelijke gezondheid. (Ensel. Nin 1991; Tesler, Mechanic 1978, 1982; Lepore, Evans, Palsanen 1991). Deze gebrekkige beheersing zou tot uiting kunnen komen in sociale inconsistenties in de kenmerken van klasse, status en burgerschap en zo verantwoordelijk zijn voor verschillen in gezondheid tussen de sociaal-economische lagen (Dressler 1988,1993a, b; Siegrist 1990).

In het hier beschreven onderzoek is getracht deze verschillende werklaringswijzen te verankeren in sociologische theorieën over sociale stratificatie en differentiatie. De centrale begrippen van deze stratificatie-theorieên - status, klasse en burgerschap - worden beschouwd als evenzovele modellen voor de mechanismen van de ongelijke verdeling van gezondheid over de sociale lagen van de samenleving. Doel van het onderzoek is na te gaan of, en zo ja, in hoeverre deze drie madlellen, afzonderlijk en gezamenlijk, bijdragen aan de verklaring van sociaal-economische gezondheidsverschillen en in welke mate cumulatie van gezondheid bedreigende of -bevorderende kenmerken en (in)consistentie in klasse-, status- en burgerschapskenmerken deze verschillen versterken of verzwakken.

\subsubsection{Concepten}

In moderne samenlevingen als de Nederlandse vindt sociale differentiatie plaats op basis van enerzijds 'natuurlijke' en aan de persoon gebonden kenmerken, zoals leeftijd, geslacht, lengte (Marmot, 1986) "gewicht, huidskleur, taal, samen te valten met het begrip stand en van anderzijds economische kenmerken die zijn besloten in het begrip klasse, van sociaal-culturele kenmerken, aangeduid met het begrip status en van de deelname aan het sociale verkeer in de samenleving, benoemd met het begrip burgerschap. Deze vier begrippen zijn niet bedoeld als hoofdjes waarondeir een aantal indicatoren voor determinanten wan gezondheid kunnen worden samengevat, ze worden hier opgevat als begrippen die verschillende mechanismen aanduiden op basis waarvan sociale differentiatie tot stand komt. Zo wijst stand op toegeschreven, sociaal verschillend gewaardeerde kenmerken en verwijst klasse naar het gegeven dat in de samenleving op grond van hun economische positie enkelen wel en een groot aantal anderen niet in staat zijn zelfstandig hum leven in te richten, casu quo zich te onttrekken aan adversieve an gezondheid-schadende leefomstandigheden. Met het begrip status worden de verschillen tussen mensen aangeduid, die niet zozeer met hun economische omstandigheden als weil met hun culturele uitrusting hebben te maken, met verschillen in waardenoriëntatie waardoor men niet alleen andere voorkeuren heeft op politiek of maatschappelijk terrein maar zich ook anders gedraagt (Colleman 1978) en met verschillen in kennis en het vermogen schadelijke en riskante gedragingen te vermijden dan well de gevolgen ervan te neutraliseren. Burgerschap, tenslotte. betreft verschillen tusisen mensen die samenhangen met de verschillende mate waarin zij deelnemen aan het sociale leven en de mate waarin zij, zonder van 
anderen afhankelijk te worden, in staal zijn economische en persoonlijke tegenslagen op te vangen en fysiek en sociaal te overlewen (Tumer 1990; 1988).

De vier begrippen betreffen alle het verschijnsel dat categorieên mensen van elkaar verschillen in de positie die zij in de sociale stratificatie innemen, maar wijzen elk voor die verschillen andere oorzaken aan. Gemeenschappelijk aan deze begrippen is dat daarmee de basale kenmerken, waarop de sociale gelaagdheid van modeme samenlevingen vooral berust - inkomen, opleiding en beroep of sociale groep - (Giddens 1989), worden verstaan als gevolgen van de wijze waarop de samenleving is georganiseerd en niet als vaststaande en niet te veranderen gegevenheden (Luhmann 1985). Op de lange termijn zijn deze basale kenmerken van sociale differentiatie zelf ook weer oorzaak van hef bestaan van sociale stratificatie: ze bestendigen zichzelf. Omdat deze basale kenmerken - inkomen, opleiding, beroepsgroep gemeenschappelijk zijn aan de begrippen klasse, status en burgerschap, zijn zij apart als SESindex ingevoerd.

In deze studie is gezondheid opgevat als subjectieve gezondheid. Enerzijds omdat de aard van het onderzoeksmateriaal een geldige meting van een klinisch-medische gezondheidsopvatting niet toelaat, anderzijds omdat met de subjectieve, dat wil zeggen door personen zelf ervaren gezondheid, het begrip gezondheid breder wordt gerepresenteerd. Het begrip subjectieve gezondheid is op drie manieren geoperationaliseerd. Deze drie operationalisaties dekken de drie betekenissen die in de Nederlandse bevolking aan gezondheid worden toegekend, gezondheid als activiteil (chronische ziekten), gezondheid als kracht ('perceived health') en gezondheid als evaluatie van een toestand (ervaren gezondheid) (Joosten 1988). Met de drie gekozen indicatoren is de subjectieve gezondheid van de Nederlandse bevolking adequaat in kaant gebracht. Gezien de samenhang van de drie indicatoren met doktersbezoek en met morbiditeit en mortaliteit op lange termijn, kan bovendien worden aangenomen dat de resultaten van het onderzoek ook geldigheid bezitten voor die aspecten van gezondheid, die in de reguliere gezondheidszorg als gezondheidsproblemen worden ervaren.

\subsection{Materiaall en methode}

In deze studie is gebruik gemaakt van het Leefsituatieonderzoek van het CBS uit cle jaren 1974. 1977, 1980 en 1983 en van het Panelonderzoek naar de gezondheid en gezondheidsbelewing van de Nederlandse bevolking in 1981 en 1983. Voor de surveys van beide onderzoeken zijn steekproeven getrokken uit de Nederlandse bevolking van 16 jaar en ouder, respectieyelijk tussen de 18 en 65 jaar. On met behulp van de beschikbare gegevens zowel sociaaleconomische status als gezondheid van de respondenten zo adequaat mogelijk te kunnen waststellen. werd beslaten uit deze bestanden uitsluitend de hoofden van huishoudens bil de analyses te betrekken. Deze selectie had tot gevolg dat in het onderzoek alleen die wrouwen zijin opgenomen, die een eigen huishouden voeren omdat zij niet, of niet meer, getrouwd zilin of samenwonen. Deze vrouwen zijn niet representatief voor het vrouwelijk deel van de Nederlandse bevolking. De mannelijke hoofden van huishoudens in dit onderzoek kunnen wel als representatief van de Nederlandse mannen worden beschouwd.

Omdat, zoals gezegd, de sociale gelaagdheid wooral berust op verschillen in inkomen, opleiding en beroep of sociale groep is op basis van deze kenmerken voor elk van de zeven gebruikte gegevensbestanden een index geconstrueerd "waarmee woor ellke respondent zijn of haar plaats in de sociale gelaagdheid kon worden bepaald (SES-index). Deze index beschrift de basiskenmerken van de sociale stratificatie; als mechanismen waardoor de sociale ge. laagdheid tot stand komt, hebben klasse, status en burgerschap deze kenmerken met elkaar gemeen. Om klasse, status en burgerschap toch onafhankelijk van elkaar te kunnen meten, zijn ze geindiceerd aan de hand van hun gevolgen, te weten leefsituatie, leefstijl en sociale 
participatie. Voor deze drie Indicatoren zijn vervolgens, op basis van het woorhanden zijnde materiaal in het CBS-Survey 1983, indexen ontwikkeld met behulp van schaalanalyse (LIKERT, MOKKEN (Meerling 1981), carrespondentie-analyse (HOMALS) en principale componentenanalyse (metrische en niet-metrische PCA: PCA. HOMALS en PRINCALS) (van Rijckevorsel, de Leeuw 1988).

Om de schaalwaarden; die deze analyses zouden opleveren, te kunnen gebruiken in de overige gegevensbestanden; zijn de antwoordcategorieën van vragen met gelijke strekking uit: die bestanden door middel van correspondentie-analyses (HOMALS) vergelijkbaar gemaakt met de antwoordcategorieen van de vragen uit het CBS-survey 1983.

De opeenvolgende surveys zijn unhoudelijk niet identiek en ook zijn vragen of antwoordcategorieen niet steeds op dezelfide wije gelormuleerd. In een aantal bestanden ontbreken sommige of zelfs alle vragen over een onderwerp. Alleen in het laatste geval is ervan afgezien een index te maken. In de andere gevallen van 'mising values" zijn de ontwikkelde indexen minder goed vergelijkbaar met de porspronkelijke index $(.10<r<.80)$. Om de indexen over de bestanden heen goed vergelijkbaar te maken, zijin die indexen, die in principe normaal zijn verdeeld, gerangordend volgens de normaal verdeling met gemiddelde nul en standaarddeviatie éen. De overige (LIKERT- en MOKKEN-schalen) zijn gerangordend als cumulatieve proporties, zodat hun range in de verschillende bestanden gellijk is.

Leetsituatie is in de bestanden geindiceerd aan de hand van woon- en werkomstandigheden en met wragen over het bazit van dure of duurzame goederen: leefstij/ met behulp van vragen over gelloof, politieke voorkeur, viljetijdsbesteding en vragen over riskante gewoonten zoals roken en alcoholgebruik: sociale participatie is geindiceerd aan de hand van burgerlike staat, lidmaatschap van verenigingen, het doen wan vrijwilligerswerk en gebruik van sociale voorzieningen.

Cumulatie van kenmerken van leefsituatie, leefstijl en sociale participatie is geoperationaliseerd als de gewogen projectie van de indices van deze begrippen op een gemeenschappelike as: daarbij is er zorg voor gedragen dat de indices ten aanzien van gezondheid gelijk zijn gericht. De weging is maximaal indien de waarde van de indices aan elkaar gelijk zijn en 0 indien éen van beide rond het gemididelde (0) ligt.

Voor de operationalisering van sociale inconsistentie is gebruilk gemaakt van de SES-index. Voor elke waarde van de verschillende indices is een SES-score bepaald. Deze is berekend als het gemiddelde van de SES-index wan de respondenten die dat kenmerk bezitten. Indien een kenmerk alleen voorkomt bij mensen uit de hoge status-categorieen, is de SES-Score hoog. kent het kenmerk geen duidelike voorkeuren voor hoge of lage status-categorieen dan zal de score rond het gemiddelde 0 varieren. (n)consistentie is geoperationaliseerd als de standaardafwijking van de SES-scores op de indices voor respectievelijk klasse, status en burgerschap. Op deze wijze zijn cumulatie en consistentie relatief onafhankelijk van de oorspronkelifke scores geoperationaliseerd.

De drie indicatoren voor subjectieve gezondheid zijn achtereenvolgens het Oordeel over de eigen gezondheid de Evaren Gezondheid en de aanwezigheid van Chronische aandoenin. gen. Het oordeal over de eigen gezondheid (OEG) verwijst naar de perceptie van eigen gezondhoid als goed of slecht of ook wel als sterk of zwak, welke perceptie niet per se samen behoeft te hangen met de aan- of afwezigheid van aandoeningen of klachten (Williams 1983). Het is een internationaal erkende maat voor gezondheid, die bij herhaling is gebleken een krachtige voorspeller te zijn van 'hardere' gezondheidsmaten (morbiditeit en mortaliteit) (Singer, Gartinkel \& Cohen 1976. Mossey \& Shapiro 1982. Kaplan \& Camacho 1983, Kaplan \& Kotler 1985, Kaplan, Barrel \& Lusky, 1988, Krzyzanowski \& Wysocki 1986. Bosma, Appels, Sturmans ๑.a. 1991). De Ervaren Gezondheid is gemeten met Vragenlijst Ervaren Gezondheid (VOEG), welke de klachten inventariseert waar men de laatste maanden last van heeft (van Sonsbeek 
1990\%. In dit onderzoek is gebruik gemaakt van de 13-items versie die de volledige VOEG (48 items) goed representeert (Joosten, Drop 1988). In verschillende Nederlandse onderzoken is aangetoond dat de VOEG discriminerend vermogen bezit ten aanzien van het onderscheid tussen zieken en gezonden en tussen hoog en laag gebruik van gezondheidszorgvoorzieningen (Dirken 1967; Visser 1983). Bovendien is vastgesteld dat er weinig reden is om VOEGscores als uiting van klaaggeneigdheid te interpreteren (van Sonsbeek 1990; van der Zee 1981). Met name de 13-items VOEG verwijst naar klachten over specifieke orgaansystemen (Joosten, Drop 1988). De aarwezigheid van chronische aandoeningen (CHRON), is gemeten als de zelf gerapporteerde aanwezigheid van een of meer chronische aandoeningen van zeer verschillende ernst. De vraag naar de aanwezigheid van chronische ziekte blijkt in het algemeen een goede schatting op te leveren van de prevalentie van langdurige en objectiveerbare lichamelijke aandoeningen (van den Bos, Habbema, van der Maas "Mohrs 1988). Eerder op de survey-gegevens van het Leefsituatieonderzoek uitgewoerde analyses voor een aantal subcategorieen van chronische zieken lieten onder meer zien aan dat zij hoger scoorden op andiere gezondheidsmaten en een significant hogere medische consumptie rapporteerden dan gezon. de respondenten (Mootz, Konings-van der Snoek 1987).

De opgebouwde modellen, ter verklaring van sociaal-economische gezondheidsverschillen die op deze begrippen zijn gebaseerd, zijn met behulp van partiele-correlatio-berekening, hiërarchische regressie-analyse (OEG, VOEG) en logistische regressie-analyse (chronische ziekten, CHRON) getoetst op de hiervoor genoemde catabestanden. In deze analyses wordt rekening gehouden met leeftijd en geslacht als standskenmerken die zowel de positie in de saciale gelaagdheid als de gezondheid kunnen beïnloeden (Everitt, Dunn 1983; Harris 1975). Regio en urbanisatiegraad zijn op dezelfde wijze behandeld en wór kenmerken van klasse, status en burgerschap als verklaring ingevoerd.

\subsection{Samenvatting van de bevindingen}

Allereerst is onderzocht of zich in Nederland inderdaad sociaal-economische verschillen in subjectieve gezondheid en chronische ziekten voordoen. Hiervoor is gebruik gemaakt van concentratiecurves, waarin voor elk van de gezondheidsvariabelen (OEG, VOEG, CHRON) de cumulatieve percentages gezonden zijn afgezet tegen de cumulatieve percentages op de SES-index. Deze curves weken, zij het in geringe mate, af van de diagonaal het minst bij de OEG, het meest bij de VOEG en CHAON; deze afwijkingen waren het kleinst voor de CBSsurvey van 1974 en het grootst voor de surveys en het Panelonderzoek in 1980 en 1983. De concilusies zijin:

* In Nederland is sprake van verschillen in subjectieve gezondheid en chronische ziakten tussen de hogere en lagere sociale lagen, zij het dat deze verschillen niet groot zijn:

* Deze verschillen zijn het geringst voor het oordeel over de eigen gezondheid (OEG) en het grootst woor de arvaring van de eigen gezondheid (VOEG) en de aanwezigheid van chronische aandoeningen (CHRON):

* De sociaal-economische gezondheidsverschillen zijn sinds 1974 groter geworden.

Vervolgens werd nagegaan of deze verschillen in gezondheid ziln toe te schrijwen aan de sociaal-economische werking van leeftijd en geslacht (onderstelling 1) dan wel aan verschillen naar regio of urbanisatiegraad. Dit bleek niet gevel te zijn. Regressievergelijkingen lieten zien dat de SES-index naast leeftij, geslacht, regio en urbanisatiegraad een eigen bijdrage levert aan de verklaring van verschillen in gezondheid. De conclusie is: 
De inwoed van klasse, staus en burgerschap op subjectieve gezondheid

- De sociaaleconomische verschillen in subjectieve gezondheid an chronische ziekten in Nederland zjin geen gevolg van de demografische opbouw van de Nederlandse bevolking. haar geografische verspreiding en de mate van urbanisatie, ergo, ze zijn geen artefact.

Voor zover regio en urbanisatiegraad staan voor verschillen in toegang tot gezondheidszorgvoorzieningen betekent deze uitkomst dat in Nederlarid daarin geen belangrijke regionale verschillen bestaan.

De volgende vraag was of de ongelike verdeling van subjectieve gezondheid en chronische zlekten over de sociale strata is te beschouwen als gevolg van neerwaartse of belemmerde opwaartse sociale mobiliteit van mensen met een slechte gezondheid. In dat geval zou sprake moeten zilin van een significante relatie tussen de SES-index en chronische ziekten, bij controle op zowel leeftijd en geslacht; als subjectieve gezondheid (OEG en VOEG) (onderstelling 2). Omdat de (vierde orde) partible correlaties, waarin leeftijd, geslacht en subjectieve gezondheid worden uitgeschakeld, geen aamwizingen bevatten woor disproportionele aantallen chronisch zieken in de lagere sociale lagen, is de conclusie:

- De sociaal-economische gezondheidsverschillen zijn niet te herteiden tot processen van 'drift' of selectie.

Onderstelling 3 werd bevestigd: onder uitschakeling van de effecten van leeftijd en geslacht, voegen leefsituatie, leefstijl en sociale participatie elk een eigen, van de SES-index onafhankelijke, bijdrage toe aan de verklaring van de verschillen in subjectieve gezondheid en chronische ziekten tussen de sociale lagen. Daarenboven bleek dat invoering van leefsituatie en leefwijze in de regressie-analyse de effecten van de SES-index op de gezondheidsmaten verzwakte; door invoering van sociale participatie werden de effecten van de SES-index iets versterkt. De conclusies luiden:

* Klasse, status en burgerschap hebben een van de sociaal-economische positie, zoals geindiceerd door inkomen, opleiding en beroep, onafhankelijk effect op subjectieve gezondheid en chronische ziekten;

* Klasse, status en burgerschap en de respectieve mechanismen voor de verklaring van sociaal-economische gezondheidsverschillen waarnaar ze verwijzen, zijn niet concurrerend. maar complementair.

* De samenthang van inkomen, opleiding en beroep met subjectieve gezondheid is voor een deel toe to schrijuen aan verschillen in klasse en status.

- Burgerschap likt te beschermen tegen de negatieve effecten van een lage sociaal-econo mische status

De invloed van leeftijd en geslacht op gezondheidsverschillen zou een gevolg kunnen zijn wan het feit dat zij oörzaak zijn voor verschillen in klasse, status en burgerschap, zodat het effect van beide zou verdwijnen na imvering van de kenmerken van deze drie begrippen in de regiressievergelijking (onderstelling 4). De uitkomsten van deze analyse verschilden voor leeftijd en geslacht en naar gelang de gezondheidsmaat. De bijdrage van geslacht aan de verklaring van sociaal-economische gezondheidsverschillen verdwijnt inderdaad voor het oordeel over de eigen gezondheid (OEG) en voor chronische ziekten (CHRON), maar niet voor de ervaren gezondheid (VOEG); de bijdrage van leeftijd verdwijnt alleen voor het oordeel over de eigen gezondheid (OEG). Bovendien bleken de effecten van geslacht op de ervaren gezondheid (VOEG) en van leeftijd op de VOEG en op chronische ziekten weliswaar te verzwakken na invoering van de SES-index, maar juist weer sterker te worden bij invoering van leefsituatie, leefwijze en burgerschap. Conclusies zijn: 
* Verschillen tussen mannen en vrouwen in het oordeel over de eigen gezondheid en in de aanwezigheid van chronische ziekten zijn te herteiden tot verschillen in klasse, status en burgerschap; mannen en wrouwen ervaren echter hun lichamelike kiachton op eem verschilende manier, ongeacht hun sociale positie:

* Lichamelijke gevolgen van veroudering doen zich voelen onathankelik van de plaats dio in de samenleving wordt ingenomen, maar klasse, status en burgerschap accentweren of verminderen de effecten van leeftijo op gezondheidsklachten en chronische ziekten.

* Verschillen tussen jongeren en ouderen in de perceptie van de eigen gezondheid als goed of slecht zijn vrijwel geheel te herleiden tot verschillen in status, klasse en burgerschap.

Deze resultaten tonen bovendien aan dat 'het oordeel over de eigen gezondheid' en 'de evaren gezondheid" van elkaar te onderscheiden aspecten van subjectieve gezondheid weergeven, die onafhankelijk van elkaar kunnen variëren (Williams 1983). Ook bevestigen ze het in $\$ 2.5$ ingenomen standpunt, dat verschillen in gezondheid tussen mannen en wrouwen en tussen jongeren en ouderen niet alleen op biologische verschillen zijn terug te voeren, maar ook te maken hebben met sociaie verschillen die ontstaan doordat mensen vanwege hun geslachts- en leeftijdskenmerken verschillen posities in de samenleving krijgen toegewezen. Leeftijd en geslacht zijn daarmee inderdaad toegeschreven kenmerken van sociale differentiatie.

Tot slot werd nagegaan of verschillen in gezondheid tussen de sociale lagen eerder aan cumulatie van adversieve of gezondheid bedreigende kenmerken in de leefsituatie, leefstijl of een gebrek aan sociale participatie waren toe te schrijven of aan inconsistenties in de kenmerken van status, klasse en burgerschap (onderstelling 5). Het cumulatie-effect onderstelt een model van blootstelling aan toxische stoffen of gezondheidsrisico's, terwijl de verklaring van socilaal-economische gezondheidsverschillen op basis van soclale (in)consistenties in kenmerken van klasse, status en burgerschap een chronisch stress model onderstelt.

De analyses voor het cumulatiemodiel lieten zien dat het wonen in een tochtige en vochtige woning en het doen van wuil en gevaarlijk werk samen niet leiden tot een veel slechtere subjectieve gezondheid dan op basis van elk van beide condities afzonderlijk is te verwachten. Evenmin is het schadelijke effect van roken op gezondheid groter wanneer er ook zwaar bij wordt gedronken. Mensen met veel contacten met de sociale dienstverlening en hulpinstanties bleken vaak chronisch ziek; ze voelen zich echter gezonder dan op basis van deze kenmerken afzonderlijk is te werwachten. Een slechte gezondheid lijkt daarom eerder keuzemogelijkheden te beperken: chronische zieken hebben minder mogelijkheden op de woning- en arbeidsmarkt dan gezonden, komen mede daardoor vaker in contact met instanties voor sociale dienstverlening en laten vanwege hun aandoening drank en alcohol staan of gebruiken beide juist zonder dat dit invloed heeft op hun gezondheidsoordeel; wellicht vanwegle de hulp die ze ondervinden van de dienstverlenende instanties, ervaren ze minder lichamelijk ongemak dan mensen die niet door die instanties worden geholpen.

De analyses van het consistentie-model tenslotte lieten zien dat discrepanties van de maatschappelijke waardering voor iemands kenmerken van klasse, status en burgerschap duidelijk de gezondheid beinvloeden waar het gaat om inconsistenties waar het individu weinig invloed op kan uitoefenen, zoals bil discrepanties in opleiding, inkomen en beroepsstatus en het gebruik van maatschappelijke voorzieningen. Mensen die van allerlei organisaties lid zijn, velerlei soorten activiteiten in hun vrije tijd ondernemen en van wie de woning kenmerken heeft die zowel sociaal gewaardeerd worden (bijvoorbeeld groot vrijstaand huis) als niet gewaardeerd (vocht, kou) zijn juist gezonder dan op basis van deze kenmerken alzonderlijk te verwachten is. 
De conclusies luiden daarom:

- Woor het cumulatiemodel is in dit materiaal geen dujdelike ondersteuning te winden.

* Het is eerder zo dat chronische aandoeningen de gedragsattematieven van mensen inperken dan dat blootstelling aan gezondheidsrisico's of dat riskante leefgewoonten elkaar versterken in hun gezondheid-schadende effecten.

- Niet alle sociale inconsistenties bedreigen de subjectieve gezondheid: sociale inconsistenties in kenmerken van respectievelijk klasse, status en burgerschap schaden de gezondheid voor zover het individu op deze geen inwloed kan uitoefenen; ze bevorderen de gezondheid in die situaties waar het individu zelf de keuze voor deze kenmerken heeft gemaakt.

Deze resultaten wizen er op dat de sociologische theorie over sociale inconsistenties dient te worden verfijnd door daarin rekening te houden met de keuzevrihheid van het individu wat betreft zijn leefomstandigheden, leefstijl en sociale participatie. Bovendien wijzen de uitkomsten op het probleem dat ongezondheid de gedragsalternatieven inperkt, waardoor niet alleen oorzaak en gevollg moeilijk zijn te onderscheiden, maar ook de relatie tussen leefomstandigheden, leefstijl en sociale participatie enerzijds en gezondheid anderzijds wordt gemaskeerd.

\subsection{Betrouwbaarheid en geldigheid van de resultaten}

De gerapporteerde bevindingen berusten op de analyse van gegevens uit zes onathankelijke steekproeven uit de Nederlandse bevolking. De twee databestanden van het Panelonderzoek zijn in deze studie onathankelijk van elkaar geanalyseerd. Gesteld dat de richting wan de gevonden verbanden bij toeval vam 0 zouden afwijken ( $p=.50$ ), dan is de kans dat de correlatie-coëfficiënten in meer dan vijf van de zeven steekproeven gelijk zijn gericht 0.07 . Indien de steekproeven van het Panel als afhankelijk zouden worden beschouwd, dan bedraagt die kans 0.125 . Per bestand is de kansi dat een coëfficient van nul verschilt op 0.05 gesteld. Bij zuiver toevallige verbanden zouden daarom slechts in $5 \%$ van de 6 steekproeven significant van nul verschillende correlaties mogen voorkomen, dat wil zeggen, in hooguit één bestand. De kans, dat bijwoorbeeld meer dan drie van de coëfficiënten in elk van de zes steekproeven bij toeval significant van mul verschillen (bij $\alpha=0.05$ ), is zeer veel geringer dan de hierboven genoemde waarden.

De gepresenteerde resultaten kunnen daarom als stabiel worden gekarakteriseerd, te meer daar de hoogte van de afzonderlijke coëfficiènten en het patroon van de onderlinge samenhangen tussen de coefficiënten per bestand niet sterk verschillen. Well moet worden opgemerkt det in de twee opeenvolgende metingen van het Panelonderzoek de rapportage van de respondenten over de aanwezigheid van chronische ziekten nogal bleek te varierren. OP individueel niveau lijkt deze variabele in de tijd niet erg stabiel te zijn, mogelijk doordat de duur ven een als chronisch opgevatte aandoening niet is geëxpliciteerd en/of respondenten herstellen van een langdurige aandoening. Echter, gegeven de te verwachten ruis, inherent aan de survey-methode en gevolg van de vele variaties in de formuleringen van de vragen in de verschillende surveys, is over het geheel genomen de stabiliteit van de bevindingen opmerkelijk, vooral ook omdat de bevindingen voor de drie gezondheidsindicatoren elkaar blijken te ondersteunen. De geobserveerde consistentie van de bevindingen geeft grond aan de concluSile dat de resultaten als betrouwbaar kunnen worden beschouwd.

Hoewel de surveys wat betreft hun doelstelling en inhoud in hoge mate overeenstemmen waren er toch nogal wat bewerkingen nodig orm indexen te construeren die in de verschillende databestanden dezelfide betekenis hadden. Dit zou aanleiding kunnen zijn voor de vraag of wellicht door deze index-constructie de gevonden verbanden aan het materiaal zijn opgelegd. 
Als antwoord op die vraag kan er op worden gewezen diat de indexen voor leefsituatie, leefstijl en burgerschap niet alleen onafhankelijk van de indicatoren van gezondheid of sociale laag zijn geconcipieerd, maar dat ze bovendien zo veel mogelik zijn ontwikkeld op basis van de gegevens uit het CBS-survey 1983. De daar gevonden schaalwaarden voor de onderscheiden items zijn in de andere bestanden ingevoerd. Het bleek dat de zo ontworpen indexen zeer goed vergelijkbaar waren met de indexen die ter controle werden ontwikkeld op de nietgehercodeerde antwoordcategorieèn in de andere bestanden $(r>80)$. De indexen zijn derhalve te beschouwen als stabiele kenmerken van Nederlandse hoofden wan huishoudens. Aangenomen mag worden dat niet alleen de indexen, maar ook de gevonden relaties onafhankelijk zijn van de bestanden waarop ze zijn onderzocht.

Bij de constructie van de SES-index bleek dat het bereikte onderwijsniveau het sterkst de plaats op de sociale index bepaalde. Zij het met uitzonderingen, is onderwijs bepalend voor de positie op de maatschappelijke ladder. Mensen zonder opleiding komen moeilijk 'aan de bak" en de hoogte van de opleiding bepaalt de uitgangspositie op de arbeidsmarkt" verschillen worden niet snel ingehaald. Het bereikte opleidingsniveau of het aantal jaren dat men heeft school gegaan is daamee een van de meest stabiele en betrouwbare indicatoren voor de plaats in de sociale hiërarchie. Inkomen en sociale groep zijn meer athankelijk van toevallige (verschillen in beloning tussen bedrijwen of bedrijfstakken; het al of niet promotie maken) en structurele factoren (leeftijd, geslacht, ethniciteit, burgerlijke staat). Door fluctuaties in inkomen en sociale groep bleken de scores in de SES-index, zoals gebruikelijk voor SES-indexen, in de lagiere ranges onnauwkeuriger dan de hogere. Daarnaast bleek dat inkomen boven twee keer modaal veel minder sterk aan de verhoging van de SES-index bijdraagt dan tot die grens. Geld is daarmee slechts tot op zekere hoogte bepalend voor de plaats op de SES-index.

De gevonden verbanden zijn niet erg sterk en de percentages verklaarde variantie niet bijzonder hoog. De aanwezigheid van chronische aandoeningen lijkt nog het minst te worden bepaald door sociale kenmerken, hoowel ook niet kan worden uitgesloten dat van de verschillende gezondheidsindicatoren deze in de surveys het minst adequaat is geoperationaliseerd, namelijk als de aanwezigheid van éen of meer chronische aandoeningen van zeer verschillende duur en ernst. De bescheiden resultaten zijn in de eerste plaats het gevolg van de geringe omvang van de verschillen in gezondheid tussen de sociale lagen. Vervolgens zijn deze uitkomsten, behaive aan de gebruikelijke ruis in het materiaal, zeer waarschijnlijk toe te schrijven aan de feitelijke afbakening van de populaties waaruit de steekproeven afkomstig zilin alls gevolg van de toepassing van de survey-methode. In thet algemeen zilin het immers vooral de "nette" burgers met een vaste woonplaats, met een zeker sociaal plichtgevoel of interesse, die bereid en in staat zijn enquêteurs te woord te staan of questionnaires in te vullen. Marginale groeperingen aan de 'onderkant" van de samenleving, thuislozen, Junkies, verstandelijk minder begaafde of psychisch labiele personen en instituutsbevolkingen worden met een survey niet of nauwelijks bereikt. De gezondheid van deze groepen laat over het algemeen te wensen over (van Weegel, Heydendael 1993; König-Zahn, C., Tax,B., Nuy, M.H.R., Hodiamont, P.D.G., Heydendael, P.H.J.M. (1993). Het is daarom aan te nemen dat met survey-gegevens sociaaleconomische gezondheidsverschillen in de bevolking, alsook de werking van de verklaringsmechanismen, worden onderschat.

Als een beperking van het huidige onderzoek zou kunnen worden gezien dat geen rekening kon worden gehouden met de gezondheidstoestand van de respondenten in het verleden. Omdat vragen over de opleiding van de ouders of het laatste beroep van de vader ontbraken. kon ook de sociaal-economische status van de ouders van de respondenten niet in de analyse worden betrokken. Er was dus geen indicatie beschikbaar van de condities waaronder de 
respondenten hun loopbaan begornen, zodat niet kon worden nagegaan of de patientencar. vieres tussen de sociaal-economische lagen verschillen.

Tenslotte kan nog worden geconstateerd dat de beperking tot hoofden van huishoudens welis. waar eeri specifieke selectie van vrouwen heeft bewerkstelligd (geen huisvrouwen, relatief veel alleenstaande, jonge en oude vrouwen), maar dat deze selectie niet tol onwerwachte bewindingen heeft geteid. Aanvullende analyses onder de uitgesloten categorie vrouwen (met een minder adequaat gedefinieerde sociaal-economische status) leverden geen afwijkende resultaten op. 
In dit slothoofdstuk wordt besproken welke betekenis de resultaten wan dit onderzoek zouden kunnen hebben voor theorievorming betreffende sociaal-economische gezondheidsverschillen. Daarbij wordt met name aandacht besteed aan de theoretische implicaties van het verband dat is gelegd tussen het begrip burgerschap en de ongelijke verdeling van gezondheid in de samenleving. Ter afsluiting vam het hoofdstuk wordt nagegaan welke consequenties de bevindingen hebben voor verder onderzoek op dit gebied en voor beleid, dat is gericht op hel verkleinen wan sociaal-economische gezondheidsverschillen in Nederland.

\subsection{Nadere specificatie van de uitkomsten voor klasse „status en burgerschap}

Om beter te kunnen begrijpen op welke manier klasse, status en burgerschap oen rol spellen bij het veroorzaken, respectievelijk hell verminderen van sociaal-economische gezondheidsverschillen is in het onderzoek ook nagegaan welke aspecten in leefsituatie, leefstijl en sociale participatie met name de gezondheidsverschillen verklaren (Schema 1). Deze uitkomsten worden hieronder voor achtereenvolgens klasse, status en burgerschap kort besproken.

Schema 4 Factoren in de leefsituatie, leefstijl en participatie die met name verantwoordelijk zijn woor verschillen in gezondheid

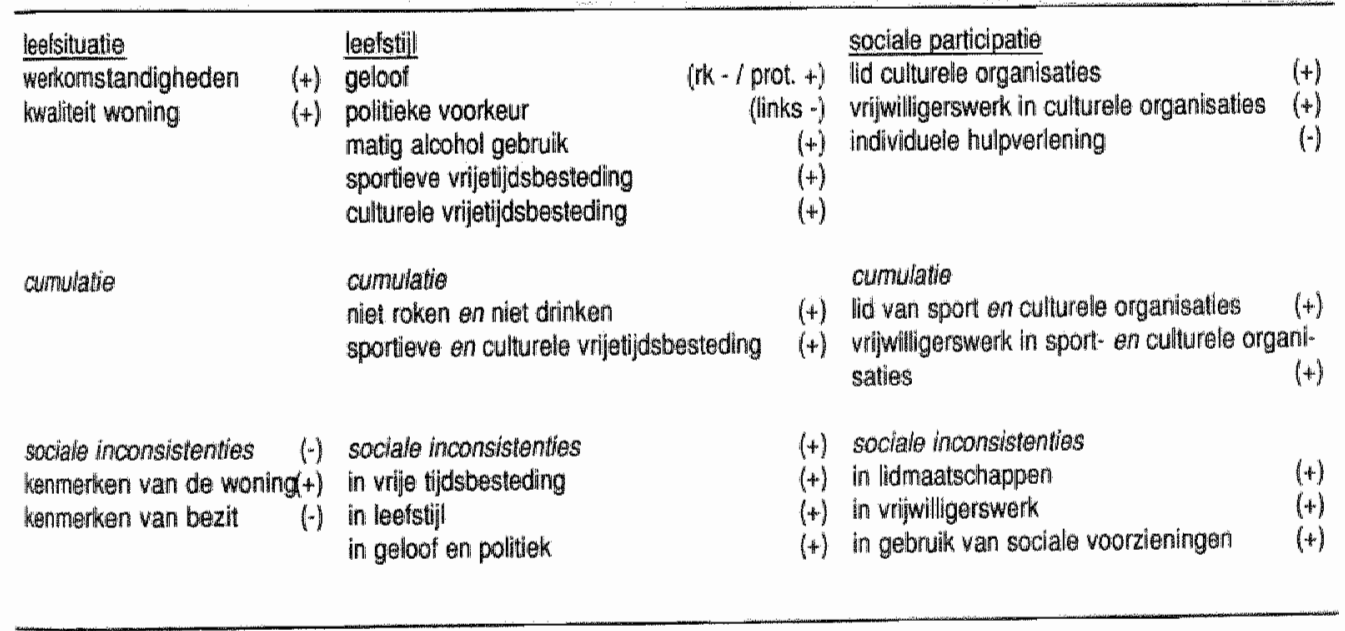

\subsubsection{Klasse en gezondheid}

De bevinding dat in ellk bestand werk- en woonomstandigheden in relatief belangrijke mate bijdragen aan de verklaring van de verschillen in gezondheid, ondersteunt de onderstelling dat klasse via het mechanisme van differentiële blootstelling aan toxische of schadelijke stoffen gezondheidsverschillen veroorzaakt. In de lagere sociale lagen kan men zich minder aan deze blootstelling onttrekken: er wardt eerder zwaar, vies of gevaarlijk werk gedaan of in een lawaaiige omgeving gewerkt en vaker gewoond in een Kwalitatief slechte, moeilijk van kou, 
wocht en tocht te vrijwaren woning, dan in de hogere sociale lagen. Van een cumulatie van effecten is echter geen sprake.

\subsubsection{Status en gezondheid}

Status wordt ondersteld sociaal-economische gezondheidswerschillen te veroorzaken via de manier waarop mensen hun leven inrichten en hun omgeving en gedrag weten te beheersen. Deze gedachte vindt steun in de consistente samenhangen van religie en politieke voorkeur met subjectieve gezondheid. Het gaat daarbij waarschijnlijk niet zozeer om het geloof in een opperwezen dat mensen beschermt tegen ongezondheid: rooms-katholieken hebben door. gaans een slechtere gezondheid dan protestanten, terwijl onkerkeliken een tussenpositie innemen (Ellison 1991). Waarschijnlijker is dat de met het geloof samenhangende verschillen in normen en waardenorientaties, die tot uiting komen in leefwijzen, gezondheidsbeleving, male van zelfbeschikking en verantwoordelikheidsgevoel, hierin een rol spelen (Levin, Vanderpool 1987: Tallis-Nayak 1982). Het verschijnsel dat rooms-katholieken meer roken en alcohol drinken dan protestanten, is hiermee in overeenstemming (Knibbe 1982; Gadourek 1963). Omdat in de analyses voor roken en drinken is gecontroleerd, wordt aangenomen dat het hier geconstateerde effect van relligie is toe te schrijven aan de mate waarin men zich in staat acht zelf richting te geven aan zijn leven en aan de daarmee samenhangende gevoelens van zelfwaardering en autonomie, die van invloed zijn op de gezondheid (Dressler 198: Elisson 1991; Edward, Cooper 1988; Lyderad, Jones 1989; Schiller, Levin 1988). Het samengaan van een politieke voorkeur voor links met een gemiddeld genomen slechtere gezondheid kan op eenzelfde wijze worden verklaard: veel mensen die op een sociaal-democratische of socialistische partij stemmen doen dat omdat zij in hun sociaal of economisch afhankelijke positie van deze partijen bescherming verwachten. Overigens kan hier ook sprake zijn van selectie: mensen die chronisch ziek of gehandicapt zijn stellen in deze politieke partijen vertrouwen omdat deze zeggen zich met name sterk te maken voor de instandhouding van de verzorm gingsstaat en zich erop beroepen vooral op te komen voor de zwakkeren in de samenleving. Selectie zou cok kunnen verklaren waarom mensen die sporten (Lamb, Dench, Brodoe: Roberts 1988) of deelnemen aan culturele activiteiten (schouwburg-, concert-en toneelbezoek of het zelf beoefenen van kunst) een betere gezondheid hebben dan gemiddeld. Hier wordt aangenomen dat ook deze activiteiten verwijzen naar waardenoriëntaties, houdingen en opvattingen, die met zich meebrengen dat mensen beter zicht hebben op hun eigen situatie wardoor zij zich beter in het leven kunnen handhaven (Bakker 1985). Bij deze uitkomsten moet worden bedach, dat effecten van leeftijd en geslacht, opleiding, inkomen, beroep en woonplaats alle zijn uitgeschakeld, zodak deze geen verklaring voor de gevonden relaties met gezondheid kunnen bieden.

Cumulatieve effecten voor poken en zwaar drinken werden niet gevonden. Well werd geconstateerd dat mensen die roken noch drinken gezonder zijn dan anderen; zij hebben evenwel vaker een chronische aandoening dan op basis van deze atzonderlijke kenmerken mocht worden verwacht, hetgeen op selectie wijst: mensen roken en drinken niet (meer), orndat ze een chronische aandoening hebben en zolang ze van deze genotmiddelen afzien woelen ze zich er wel bij. Evenzo zouden anderen niet van roken en veel drinken afzien zolang ze zich er gezond bij voelen; door selectie is er dan geen cumulatief effect aantoonbaar (Kozlowski, Ferrence 1990). Deze hypothese is des te waarschijnlijker omdat een actieve vrijetijdsbesteding de effecten van roken en drinken volledig overschaduwt. 


\subsubsection{Burgerschap en gezondheid}

De bescheiden effecten van de kenmerken van burgerschap op het oordeel over de eigen gezondheid (OEG) en op de ervaren gezondheid (VOEG) worden vooral veroorzaakt door het lidmaatschap van cultureel georiënteerde verenigingen of het daarin verrichten van vijiwilligerswerk en door geen gebruik te maken van voorzieningen voor individuele hulpverlening. Hoewal een selectie-effect niet is uit te sluiten gezien het feit dat onder deze voorzieningen ook medische psychotherapie valt, is dit niet bijzonder waarschijinlijk omdat relatief weinig mensen in deze bestanden van deze vorm van hulpverlening gebruik maken en voorts omdat sociale raadslieden en wetswinkels niet per definitie door minder gezonden en mensen met psychische klachten worden gebruikt. In overeenstemming met de bevindingen voor leefstijl, dat sportieve en culturele vrijetijdsbesteding een positief effect op de gezondheid hebben, is ook de combinatie van lidmaatschap en/of vrijwilligerswerk in sportwerenigingen én culturele organisaties salutogeen. Hoewel ook hier selectie mogelijk is, lijkt dit effect minder waarschijnlijk omdat met name voor het lidmaatschap van de laatstgenoemde organisaties een goede gezondheid niet per se een voorwaarde is.

thet ontbreken van enige invloed van burgerlijke staat is, in het licht van de bestaande literatuur waarin aan het huwelijk, althans voor mannen, een beschermend effect wordt toegeschreven, enigszins verbazend. Gehuwden in het algemeen en nimmer gehuwde vrouwen in het bijzonder zouden volgens die literatuur over het algemeen gezonder zijn dan mensen die door scheiding of overlijden van de partner niet meer gehuwd zijn (Thoits 1986, 1987; Querido 1991: Sherbourne Hays 1990). Waarschijnlijk is het ontbreken van enig effect van de burgerlijke staat op de gezondheidsindicatoren toe te schrijven aan de beperking van de onderzoekspopulatie fot (overwegend mannelijke) hoofden van huishoudens. De gescheiden en verweduwde hoofden van huishoudens in de bevolking zijn voor het merendeel vrouw. Bovendien is in alle analyses voor geslacht gecorrigeerd. Het effect van het "niet meer gehuwd zijn" wordt daardoor geneutraliseerd. Overigens wijzen de tekens van de coëfficiënten wel in de verwachte richting.

De resultaten, die in dit boek zijn gepresenteerd, zijn niet nieuw in zoverre zij de in andere studies aangetoonde werking van bekende mechanismen in het ontstaan en bestendigen van sociaal-economische gezondheidsverschillen bevestigen. De bevinding dat deze mechanismen complementair zijn en elkaar niet onderstellen of uitsluiten, is echter wel nieuw. Nieuw is ook de aanwijzing dat een ten volle gerealiseerd burgerschap bescherming biedt tegen nadelige effecten van een lage sociaal-economische status voar de gezondheid, aanleiding om in de volgende paragraten de betekenis van deze uitkomsten voor theorie- en hypothesevorming op het gebied van de sociaal-economische gezondheidsverschillen nader te beschouwen.

\section{2 \\ Burgerschap en gezondheid: een theoretische beschouwing}

De reden om, ondanks de bescheiden omvang van de bijdrage van burgerschap aan de verklaring van sociaal-economische gezondheidsverschillen, toch een nadere beschouwing te wijden aan het begrip burgerschap, is tweeërlei. In de eerste plaats is aan te nemen dat de gevonden effecten een onderschatting vormen van de werkelijke (beschermende) effecten van burgerschap. Het is immers zeer waarschijhlijk dat de 'nette burgers' bias, die inherent is aan de toepassing van de surveymethode $(\$ 7.4)$, zich vooral zal hebben voorgedaan in de meting van burgerschap: het ontbreken in de verschillende steekproeven, van marginale groeperingen aan de 'onderkant' van de samenleving, betekent bijna per definitie een ernstige en systematische beperking van de variatiebreedte wan de 'variabele' burgerschap. In de tweede plaats zijn de onderzoeksresultaten theoretisch en ook praktisch relevant. Hoewel al eerder is aange- 
toond dat van sociale participatie een gezondheid-beschemende werking uitgaat (Badurat 1980; Kaplan, Cohen 1983), was tot op heden het salutogene effect van burgerschap onbekend.

Verschillende studies hebben laten zien dat sociaal netwerk en sociale steun direct of indirect. via buffering, effect hebben op het optreden van stress en zlekte (Wethington, Kessier 1986: Litwak, Messer 1989). Het begrip sociaal netwerk, dat eerder wiskundig dan sociologisch is: onderbouwd, en de begrippen persoonlijk netwerk en sociale steun, die kunnen worden beschouwd als afgeleid van psychologische theorieen over coping, bieden inzicht in de mitigerende werking van gezamenlike activiteiten of contacten met relevante anderen ten aanzien van gezondheid-schadende effecten van fysiek en/of psychisch belastende omstandigheden. Ze geven echter geen verklaring voor het verschijnsel dat, ongeacht de ontvangen steun, imbedding in een sociaal en maatschappelijk kader eveneens positief samenhangt met gezondheid (Moen 1989). Via de psychologische constructie van een positief gewaardeerd zelfbeeld en ik-sterkte is er nog wel een brug te slaan tussen sociale steun en adequate coping enerzijds en individuele gezondheid anderzijds, maar er ontbreekt een begrip dat de verbinding legt tussen de inbedding van individuen in sociale en maatschappelijke verbanden en gezondheid als maatschappeligk verschijnsel. De uitkomsten van dit onderzoek wijzen op burgerschap als een bruikbaar concept. Het is daarom wan belang de betekenis van deze resultaten voor theorieên over burgerschap en de relatie met gezondheid nader uit te werken.

\subsubsection{De betekenis van burgerschap}

Het begrip burgerschap werd in 1949 door Marshall gebruikt om te beschrijven hoe in de afgelopen tien eeuwen de bewoners van Engeland geleidelijk aan hun autonomie hebben bevochten. Met het recht op persoonlijke vrijheid (afschatfing van horigheid), op bezit en op toegang tot rechtspraak werd in de achttiende eeuw het civial (of juridisch) burgerschap gerealiseerd. In de vorige eeuw werd tot aan de Eerste Wereldoorlog via de arbeiders- en vrouwenstrijd, het rechl op politieke vertegenwoordiging en daarmee politiek burgerschap bevochten: ha de Tweede Wereldoorlog werden sociale en economische grondrechten geformuleerd en voorzieningen gerealiseerd die de bevolking wconomische en sociale zekerheid boden. Het sociaal burgerschap werd hiermee gerealiseerd. Voor Marshall betekende dit dall alle burgers ongeacht hun stand, klasse of status, volledig deel kunnen hebben aan het maatschappelijk verkeer.

Het burgerschap, zoals dat verankerd ligt in grondwet, algemene en specifieke wetten, is in principe toegankelijk en gegarandeerd woor alle leden van de samenleving, althans het is formeel niet voorbehouden aan bepaalde klassen, beroepsgroepen of statuscategorieen. Het staat leder vili zijn of haar burgerschap ten volle te realiseren door op alle terreinen van het leven aan de samenleving deel te nemen. In de ideale, Marshalliaanse opvatting betekent het burgerschap de onbelemmerde en gelijkwaardige deelname van actieve en autonome individwen aan het maatschappelijk verkeer. In Marshalls visie is het de theoretische verantwoording van de verzorgingsstaat.

Juridisch, politiek en sociaal burgerschap vormen de formele kaders waarbinnen individuen in de samenleving handelen: deze definiëren in de verschillende bereiken van het leven de rechten en plichten van de veden van een samenteving. Voor de samenleving betekent het burgerschap ordening en beheersbaarheid van de gedragingen van haar individuele leden, vcor het individu betekent het bescherming, bestaanszekerheid en de mogelijkheid aan de samenleving deel te nemen en daarin autonoom te handelen. Het juridisch burgerschap verschaft zekerheid omtrent de eigen handelingsbevoegdheden en die van de medeburgers en van de staat. politiek burgerschap schept de mogelijkheid invloed uit te oefenen op de vormgeving van de eigen leefomgeving. Het stelsel van sociale zekerheid en de algemene 
toegankelikheid van onderwijs en gezondheidszorg (sociaal burgerschap) maken het in principe mogelijk te ontsnappen aan het dilemma van Thorbecke, dat weliswaar de wet alle burgers aan elkaar gelijk stelt, maar dat verschillen in bestaanszekerheid deze gelijkheid de Hacto ontkrachten. Het burgerschap vormt daamee een schamier dat maatschappij en individu verbindt.

In de praktijk kent het burgerschap verschillende modaliteiten. Om te beginnen kan de samenlewing, door middel van wet en regelgeving, beshiten aan categorieën vain personen, die al dan nilet terecht als een gevaar voor de samenleving worden gezien, die vanwege hun lazkbaar gedrag het burgerschap niet langer waardig worden geacht of die handelingsonbekwaam worden bevonden, de toegang tot het burgerschap geheel of gedeeltelijk te ontzeggen of hen het burgerschap geheel of gedeeltelijk te ontnemen. Dit geldt bijvoorbeeld voor illegale immigranten, asylzoekers, politieke gevangenen, landverraders, weroordeelde criminelen, krankzin nigen en zwakzinnigen.

Ook de burgers zelf kunnen er voor kiezen om van thun rechten niet volledig gebruik te maken. Op grond van persoonlijke opvattingen, voorkeuren of levensfase maken mensen werschillend gebruik van de mogelijkheden die in de positie van burger zijn besloten, geven zij een verschillende invulling aan hun rol als burger. Men doet niet altijd aangifte van diefstal of mishandeling, evenmin vraagt iedereen die daartoe formeel gerechtigd is een uitkering aan; de meeste mensen opteren niet woor de realisatie van het passieve kiesrecht, veel mensen zien ook af van hun actieve kiesrecht; sommigen zijn via (bestuurs)lidmaatschappen van tal van organisaties maatschappelijk buitengewoon actief, anderen kiezen voor een meer teruggetrokken bestaan. De redenen voor deze keuzen varieren van persoon tol persoan en van geval tot geval. Burgerschap is daarmee zowel een abstract en formeel toegeschreven kenmerk (rechten en plichten), als ook een concreet te verwerven kenmerk, dat identiteit verleent (Shotter 1993) en mensen voor anderen herkenbaar maakt.

Heden ten dage doet zich in vrijwel alle West-Europese democratieën een ontwikkeling voor, waarin onder handhaving van het formele recht op sociaal burgerschap voor alle leden van de samenleving, bepaalde categorieën burgers in materieel opzicht buiten hun will of toedoen geheel of gedeeltelijk van een volledig burgerschap worden uitgesloten. De alom gepercipieerde noodzaak tot terugdringing van financieringstekorten van de overheid en beperking van de collectieve uitgaven leidt tot bezuinigingen in de sfeer van de sociale zekerheid, waardoor mensen die daarvan voor hun bestaanszekerheid athankelijk zijn, worden belemmerd in hun deelname aan maatschappelijke activiteiten en daarmee in de feitelijke realisering van hun sociate burgerschap. Het is met name deze ontwikkeling, die heeft geleid tot een hernieuwde belangstelling voor het begrip burgerschap in vooral de Angelsaxische literatuur. De recente discussie over het begrip burgerschap komt voort uit onvrede met de groeiende discrepantie tussen enerzijds de juridisch en politiek formeel gelijke kansen en anderzijds de feitelijk sociaal-economische ongelijkheid. De discrepantie tussen de formele rechten en de verworven magelijkheden komt het scherpst tot uiting bil de zwaksten in onze samenleving. door Ghandi gedefinieerd als de vier L'len, "the Least, the Last, the Lost and the Latest", ofwel de financieel minst draagkrachtigen, de zwakbegaafden en goedgelovigen, de pechvogels, de drugverslaafden of psychiatrisch patiënten en de 'achter het net vissers', de mensen die altijd achter in de ril staan bij de verdeling van werk en uitkeringen (Schuyt 1991). De studies over burgerschap betreffen vooral deze categorieem mensen en zijn er op gericht oplossingen aan te dragen om de discrepanties tussen de formele rechten en feitelifke situaties op te heffen (Adriaansens 1994). 
De discussies over burgerschap maken duidelijk dat de formele gelikstelling geen voldoende voorwaarde is voor een volledige realisering vain het burgerschap voor alle teden wan de samenieving die dat zouden willen: niet iedere burger is in staat om op eigen kracht volwaar dig aan de samenteving te participeren.

volwaardig burgerschap onderstelt een aantal condities, waaraan niet alle burgers voldoen. Hol burgerschap, de identiteit van het indwidu als burger, kan alleen worden gerealiseerd in handelingen, in actieve deelname aan het maatschappelike verkeer. Men wordt als hel ware een volwaardig burger door het te zijn. Voorwaarden voor een actieve maatschappelijke participatie variëren van gedeelde normen en waarden, kennis, inzicht en vaardigheden tot financiele middelen en fysieke energie, geestelijke alertheid en de beschikking over alle essentielle lichaamsfuncties. Deze condities zijn in de samenteving niet gelijkelijk verdeeld, maar hangen samen met de sociaal-economische positie van de leden van de samenleving. Hoewel enerzijds het burgerschap toegankelijk is voor alle leden van de samenleving, ongeacht hun stand, klasse of status, en mensen de mogelikheid biedt om ondanks beperkingen die hun sociaal-economische positie met zich meebrengt, autonoom te functioneren en aan de samenleving deel te nemen, wordt anderzijds de mate waarin burgers in staat zijn hun burgerschap te realiseren (mede) bepaald door kenmerken van stand, status en klasse. Inmiddels is gebleken dat het claimen van sociaal burgerschap, bijvoorbeeld door beroep te doen op een uitkering, thet burgerschap inperkt: men moet anderen inzicht geven in de financiele en huiselijke situatie, de controle van sociale rechercheurs moet men zich laten welgevallen en men is: niet meer vril te beslissen of men met lemand huis en haard, lief en leed zal delen. De verzorgingsstaat vond en vindt haar legitimering in het opheffen van deze paradox. Gezien het beschermende effect van burgerschap tegen de negatieve gevolgen van klasse en status voor de gezondheid zoals in dit onderzoek gevonden, is de mate waarin de verzorgingsstaat er in slaagt om belemmeringen voor een volwaardig burgerschap op te heffen, van rechtstreeks belang voor de volksgezondheid.

\subsubsection{Burgerschap en 'sense of coherence'}

Om een verklaring te kunnen geven van de beschermende werking van burgerschap, ofwel de volwaardige participatie aan de samenleving, is het nuttig het begrip 'sense of coherence' le introduceren. Dit begrip werd door Antonovsky $(1979 ; 1987)$ gebruikt om het verschijnsel te verklaren dal sommige mensen ondanks kampervaringen in de Tweede Wereldoorlog, krijgsgevangenschap in China of Korea of het verlies van vrouw en kinderen toch een min of meer nomaal leven in goede gezondheid weten op te bouwen terwijl anderen door deze ervaringen fysiek of mentaal instorten. Het enige gemeenschappelike in de levensverhalen van de eersten was dat zij allen, ongeacht hun afkomst, geloof, inkomen of beroep, in staat waren zichzelf buiten de gebeurtenissen te plaatsen "tijdens deze gebeurtenissen hun rol in de situatie konden analyseren en ernaar probeerden te handelen. Antonovsky (1979; 1987) ontwikkelde het begrip 'sense of coherence' om het vermogen van een individu aan te geven om stressoren met succes hanteerbaar te maken. De 'sense of coherence' is een persoonlijke copingstijl, a global orientation that expresises the extent to which one has a pervasive, enduring though dynamic feeling of confidence that:

(1) the stimuli deriving from one's internal and external enviromments in the course of fiving are siructured, predictable and explicable;

(2) the resources are available to one to meet the demands posed by these stimuli, and (3) these demands are challenges, worthy of investment and engagement. (o.c. p.19) Mensen die in sterke mate een 'sense of coherence' bezitten, zijn over het geheel genomen gezonder dan anderen en hebben minder last van eventuele lichamelijke beperkingen en ongemak (Langüus, Bjorvall 1993). 
Het concept "sense of coherence' is verwant aan de psychologische begrippen 'hardiness' en 'self esteem', maar het plaatst de coping stijl van het individu meer in een maatschappelike context. Resultaten van recent onderzoek maken het waarschijnlijk dat 'sense of coherence" een vrif stabiele eigenschap van een persoon is die samengaat met minder lichamelijke en psychische klachten (Langius, Bjorvell, Antonovsky 1992; Flannery, Flannery 1990), zil het minder stabiel en gevoeliger voor de aanwezigheid van stressoren dan 'anxiety' (Carmel, Bernstein 1989).

Burgerschap is te definierren als "a set of practices (juriclical political, economic and cultural) which define a person as a competent member of society, and which as a consequence shape a flow of resources to persons and social groups' (Turner 1993). Burgerschap onderstelt en versterkt de 'sense of coherence'. De realisering van burgerschap onderstelt autonome individuen die in hun gedrag niet naar willekeur door anderen worden beperkt of overtroetd, kortom individuen die iets aan hun problemen kunnen en moeten doen; het onderstelt een zeker begrip of inzicht in de situatie waarin wordt gehandeld en het onderstelt dat men verantwoordelijkheid neemt voor de uitkomst van zijin of haar handelen. Deze drie aspecten tonen een sterke overeenkomst met de drie aspecten van Antonovsky's 'sense of coherence': dat men het idee heeft dat men problemen kan aanpakken ('manageability'), dat men begrijpt wat er aan de hand is ("comprehensability") en de problemen belangrijk vindt en betekenis kan geven ('meaningfulness").

Als copingstijl onderstelt en versterkt de 'sense of coherence' burgerschap. Naarmate men vaker zelfstandig zijn problemen heeft opgelost, zal het vertrouwen dat men zelf richting kan geven aan zijn leven toenemen. De basis voor de 'sense of coherence' wordt dan ook al in de vroege jeugd gelegd, in een omgeving waarin het kind door te experimenteren en te onderzoeken kan leren hoe de wereld om hen heen er uit ziet ('comprehensability'), in een omgeving die het laat voelen dat men om hem geeft en dat wat het doet van belang is ('meaningfulness') waardoor het in allerlei situaties leert zichzelf en de wereid om zich heen te beheersen ("manageability') (Antonovsky 1987, p.89 a.v.). Armoede, ziekte en gebrek kunnen leiden tot apathie en anomie, het gevoel 'er niet (meer) bil te horen'. Dit is echter niet altijd het geval. Het gegeven dat sommige kinderen uit ghetto's wel en andere niet in staat zijn om zich wit hun milieu los te maken, dat sommigen ondanks oorlogservaringen en persoonlijke tegenspoed overeind blijven en anderen er aan onderdoorgaan, ligt aan de basis van het idee van 'sense of coherence'. Daamee bepaalt burgerschap de kans op een grote mate van 'sense of coherence' maar, omdat dit een vrij stabiel persoonlijk kenmerk is, is de invloed van de "sense of coheren$c e$ " op de volledige realisatie van burgerschap direkter.

Klasse en status bepalen voor een deel de mate waarin burgerschap verwezenlijkt kan worden (materiële condities) en beinvloeden de kans op een hoge 'sense of coherence'. De "sense of coherence" beinvloedt vervolgens de beslissing of men actief aan het sociale leven deelneemt of zich er uit terugtrekt.

Zowel de 'sense of coherence' als het burgerschap hebben invloed op de mate van 'distress' die weer van invloed is op de gezondheid. Daarbij gaat de invloed van burgerschap via socialle participatie terwijl intra-psychische mechanismen de invloed van de 'sense of coherence' op distress zouden verklaren (Schema 5).

De plausibiliteit van dit model voor de beschermende werking van burgerschap en van "sense of coherence' wordt ondersteund in studies waarin wordt aangetoond dat mensen die hun eigen leven in moeilijke omstandigheden weten to beheersen minder stress ervaren en zich gezonder voelen dan mensen die de greep op hun omgeving missen. Zo bleek in een onderzoek naar arbeid en gezondheid dai naast hinder van de fysieke werkomstandigheden, de mogelijkheden de werkzaamheden zelf te regelen of "work-latitude" de belangrijkste verklarin- 
Schema 5 De relatie tussen Klasse, status, burgerschap, "sense of coherence", "distress" en gezondheid

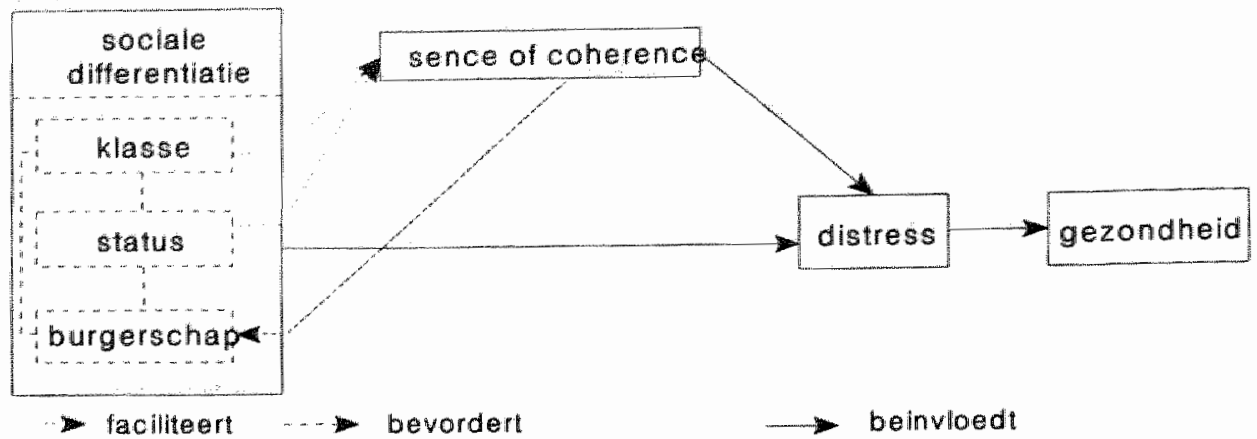

gien vormen voor het bestaan van verschillen in gezondheld tussen de sociale lagen (Schroër CAP. Bullinga RS 1990). In een andere studie kon worden aangetoond dat moeders van ernstig gehandicapte kinderen zich gezonder en minder moe voelen naarmate zij meer greep hebben op de gezinsorganisatie (Joosten, de Bruyn Ouboter-Kooij, Drop $n$ Philipsen 1990; Raif. Rimmerman 1993). Onzekerheid over diagnose, behandeling en natuurlijk beloop wordt waak genoemd als de factor die het leven meer verlamt dan de symptomen van de ziekte zelf (Lundman, Norberg 1993).

In dit werband zijn de bevindingen met betrekking tot sociale inconsistentie eveneens van belang. Ondersteld werd dat sociale inconsistentie in het algemeen, door verstoring van hetgeen men op basis van zijn status vereist of gepast acht, tot chronische stress zou loiden en daarmee tot een mindere gezondheid. Dit blikt echter alleen op te gaan in hel geval inconsistenties van buiten af zijn opgelegd door de omstandigheden of uiting zijn van gebrek aan financiele draagkracht. Zelfgekozen inconsistenties in de kenmerken van leefstijl en burgerschap hebben veeleer een salutogeen effect. Indien "sense of coherence' een mediator is tussen de leefsitatie en gezondheid, dan kunnen enerzijds de van buiten af opgelegde inconsistenties worden gezien als omstandigheden waarover het individu geen zeggenskracht heeft en anderzijds inconsistenties in statuskenmerken waar men zelf woor kiest uitdrukking zijn van persoonlijke autonomie. De relatie met gezondheid verloopt voor klasse en status dan analoog aan die met burgerschap.

De bevindingen voor burgerschap geven aanleiding voor de hypothese dat de 'sense of coherence de relatie tussen maatschappelijke structuur en gezondheid van de leden van de samenleving conditioneert. Immers, ongeacht klasse- en statuskenmerken heeft men een betere gezondheid naarmate burgerschap vollediger wordt gerealiseerd, casu quo de "sense of coherence" groter is. De deelname aan het sociale leven of de maatschappelijke inbedding is in beide gevallen groter dan het geval is bil een in mindere mate van burgerschap of 'sense of coherence".

Gezien de centrale rol van sociale participatie in burgarschap en 'sense of coherence' moet de vraag worden beantwoord of niet selectie de relatie tussen beide begrippen verklaart. Er zou sprake zijn van selectie indien men vanwege een goede gezondheid beter aan allerlei maatschappelijke activiteiten kan deelnemen, waardoor men zijn burgerschap vollediger realiseent en de 'sense of coherence" wordt versterkt: stijging op de maatschappelijke ladder is dan waarschijnlijker dan daling. In dat geval zou sociale particiaptie de relatie tussen de SES-index en gezondheid verzwakken, zoals ook klasse- en statuskenmerken deze relatie verzwakken. 
Het tegendeel lijkt eerder het geval waardoor sociale participatie los van de positie op de SES-index een rol speelt (\$ 5.4).

Ook in longitudinaal onderzoek onder volwassenen wordt weinig ondersteuning gevonden voor de selectie- en drifthypotheses (Marmot 1986). Ironisch genoeg worden in studies naar pasgeborenen (Arntzen, Samuelsen, Magnus, Bakketeig 1994; Oakley 1993) en jeugdigen (van der Lucht 1992; Oakley 1994; Wadsworth 1986) meer aanwijzingen gevonden woor processen van selectie en "drift". Kennelijk gebeurt de positietoewijzing in de samenleving al in de moederschoot: kinderen van alleenstaande moeders en van moeders in kommervolle omstandigheden hebben over het algemeen meer complicaties bill de zwangerschap en bevalling en deze kinderen hebben bijgevolg meer problemen in hun lichamelike en geestelijke ontwikkeling (Oakley 1994). Recent onderzoek liet zien dat financiéle problemen in het ouderlijk gezin een belangrijkere negatieve invloed hebben op de gezondheid van volwassen dan alleen sociale gezinsproblemen. (Rahkonen, Lahelma, Huuhka 1994; Lundberg 1991). Bestaansonzekerheid Mjkt daarmee een conditie die belemmerend werkt op de socialisatie van de leden van de samenleving tot autonome leden van de samenleving.

Op basis van het voorafgaande leidt tot het postulaat dat 'sense of coherence' een belangrijk mechanisme vormt voor sociaal-economische gezondheidsverschillen doordat:

- Klassen verschillen in de mogelijkheid om adversieve levensomstandigheden uit de weg le gaan, ergo in de blootstelling aan deze factoren;

- verschillen tussen onderscheiden sociale status samengaan met verschillen in de mate waarin men heeft geleerd zijn eigen leven beheersen;

- verschillen in burgerschap verschillen in sociale participatie weergeven, waardoor, anders dan via materiele middelen (klasse) of gezag (status) oplossingen kunnen worden gevorden om adversieve levensomstandigheden tegen te gaan of te omzeilen (buffering):

- verschillen in blootstelling aan adversieve levensomstandigheden en verschillen in 'sense of coherence' verschillen in 'distress' veroorzaken, die op hun beurt via verandering van het immuunsysteem verantwoordelijk zijn voor verschilen in gezondheid.

\subsection{Betekenis van de resultaten voor onderzoek en beleid}

\subsubsection{Consequenties voor verder onderzoek}

De voorafgaande beschouwing en de resultaten van het onderzoek geven aanleiding tot nieuwe vraagstellingen en suggesties voor andere methodes van onderzoek ter verklaring van sociaal-economische gezondheidsverschillen.

Vanuit dit onderzoek gedacht, zou het wenselijk zijn de analyses zoals hier gerapporteerd te kunnen uitwoeren op andere dan surveygegevens. In de loop van deze studie zijn een aantal beperkingen van deze methode naar voren gekomen, die van imvloed zouden kunnen zijn op de resultaten van de analyses.

Een eerste beperking wordt gevormd door de reeds besproken selectie-bias in de eurveysteekproef, waandoor de laagste lagen van de samenleving nauwelijks in het onderzoek zjin betrokken, met hoogstwaarschijnlijk als gevolg een onderschatting van de sociaal-economische gezondheidsverschillen.

Een tweede belangrijk bezwaar is, dat intra- en intergenerationele verschillen in gezondheid, die meer licht zouden kunnen warpen op de mechanismen die ten grondslag liggen aan sociaal-economische gezondheidsverschillen, met transversaal survey-onderzoek niet zijn te traceren. De indeling in beroeps- of welstandscategorieen in een survey is onvermijdelijk tamelijk grof, waardoor zaken als herplaatsing in een andere functie, aanpassing van het werk aan de handicap en beperkingen in carrieremogelijkheden niet of nauwelijks zijn na te gaan. Evenzo is met survey-onderzoek moeilijk vast te steilen inhoeverre via de sociale zekerhelids- 
wetgeving (met name de Wet op de Arbeidsongeschiktheid, de Algemene Arbeidsongeschiktheidswet, die Ziektewet en de Algemene Bijstandswet) door inkomenssuppletie wordt woorkomen dat mensen onder het bestaansminimum terechtkomen, waardoor eventuele mechanismen wan 'drift' en selectie worden gemaskeerd. De mogetijke effecten van 'drift' en selectieprocessen kunnen met deze grove methoden van onderzoek niet of nauwelliks worden achterhaald.

Ten derde is er het probleem van de richting van de relaties tussen de verklarende variabelen en de gezondheidsindicatoren, met name als het gaat om de variabelen die de indexen voor status en burgerschap samenstellen. Weliswaar kan op grond van redeneringen en literatuurreferenties de causaliteit van de samenhang van leefwize en sociale participatie met gezondheid aannemelijk worden gemaakt, maar strikt genomen is deze causaliteit niet bewezen en moet rekening worden gehouden met de mogelijkheid dat gedragingen en opvattingen gevolg zijn van een minder goede gezondheid.

Uit wetenschappelijk methodologisch oogpunt zou het daarom aanbeveling verdienen om:

a. Onderzoek op te zetten waarin de leefomstandigheden en gezondheidstoestand van de laagste sociale lagen en van 'randgroepen' systematisch worden onderzocht, eventueel via de verschillende organisaties die zich in hun activiteiten richten op deze bevolkingscategorieën.

b. Kwalitatieve 'case history studies' te doen, bij welomschreven selecties uit rellevante bewolkingsgroepen: hoge/midden/lage/laagste SES; stijgers/ dalers; werkenden/werklozen/ WAO'ers; kerkelijken/onkerkelijken; gezonden/(chronisch)zieken, teneinde de werking van de verschillende verklaringsmechanismen in de persoonlijke levensloop te kumnen nagaan.

c. Longitudinaal loopbaanonderzoek op te zetten, bijwoorbeeld bij verschillende cohorten van abituriënten van verschillende schoolsoorten, waarin zowel de effecten vam 'drift' en selectie in de verklaring van saciaal-economische gezondheidsverschillen "als de causaliteit van de relatie van leefwijze en sociale participatie met gezondheid zouden kunnen worden vastgesteld.

d. In schoolloopbaanonderzoek als determinerende variabelen niet alleen de sociale status van de ouders op te nemen maar ook kenmerken van de gezondheid van het kind.

Naast deze vooral methodologische overwegingen, zou het vanuit theoretisch oogpunt van belang zijn om de analyses uit te voeren op materiaal dat specifiek voor de onderzochte vraagstelling zou zilin verzameld zodat de begrippen klasse, status en burgerschap precies zouden kunnen worden geoperationaliseerd en gemeten. Bovendien ware het wenselijk de relatie tussen de drie begrippen aan een nader onderzoek te onderwerper. In verband imet de hier ontwikkelde hypothese aangaande het onderliggende mechanisme wan sociaal-economische gezondheidsverschillen, zou het tenslotte mogelijk moeten zijn het model aan te vullen en te preciseren met de irwaering en meting van het concept 'sense of coherence'. Uit weten. schappelijk theoretische oogpunt verdient het daarom aanbeveling om:

e. Bij welomschreven bevolkingsgroepen de precieze relatie tussen klasse, status en burgerschap longitudinaal na te gaan en hun relatie met 'sense of coherence' en gezondheid te onderzoeken.

i. In panel-onderzoek na te gaan in welke mate burgerschap van invloed is op het vermijden wan gezondheidschadende aspecten van klasse en status.

9. In ean experimentele studie onder immigranten de invloed na te gaan van formele aspecten van juridisch, sociaal en politiek burgerschap op de 'sense of coherence' en gezondheid. 
h. In psychologisch onderzok de relatie na le gaan tussen 'sense of coherence' enerzijds en psychologische constructen als self-esteem, ego-strength en beheersingsorientatie anderzijds, teneinde na te gaan op welke wijze de 'sense of coherence" zou kunnen worden beinnloed.

\subsubsection{Consequenties voor beleid}

\section{a Betekenis voor beleid}

Voor degenen die verantwoordelijkheid dragen woor de gezondheid en het welzijn van het Nederlandse volk is het in de eerste plaats van belang te weten dat in Nederland de gezondheil ongelijk over de sociale lagen is verdeeld en dat in de onderzochte periode de sociale verschillen in gezondheid zijn toegenomen. In de tweede plaats is van belang dat de geconstateerde gezondheidsverschillen te maken hebben met in de Nederlandse samenleving bestaande verschillen in klassen, status en burgerschap, waarbij de gevolgen van klasseverschillen voor de gezondheid de belangrijkste zijn. Het ziln eerder structurele kenmerken van de samenleving dan gedragingen of kenmerken van individuen, die aan de sociaal-economische gezondheidsverschillen ten grondslag liggen. Daarbij kan worden opgemerkt dat het niet zozeer de cumulatie van gezondheidsrisico's is die verschilien in gezondheid verklaart dan wel de mate waarin mensen zich niet aan deze risico's kunnen onttrekken.

Wat is nu de relevantie van deze wetenschap? Wat is de betekenis van deze resutaten voor het bestuit beleid te ontwikkelen of te versterken dat er op is gericht de sociale angelijkheid in gezondheid op te heffen dan wel te verminderen of op zijn minst niet verder te laten toenemen en wat betekenen de uitkomsten voor de keuze van beleidsmaatregelen? lmmers, er is gebruik gemaakt van subjectieve gezondheidsmaten, de verschillen in gezondheid zijn niet groot en ook de bijdragen van de kenmerken van klasse, status en burgerschap aan de verklaring van die verschillen zijn, hoewel significant, bescheiden.

De gepresenteerde onderzoeksresultaten zijn om een aantal redenen van belang voor verschillende sectoren van de samenteving.

In tal van studies is aangetond dat de gebruikte indicatoren van gezondheid voorspellend zijn voor morbiditeit en mortaliteit op lange termign (Kaplan, Camacho 1983; Kaplan, Kotler 1985). voor doktersbezoek (van der Zee 1981; Mootz, Konings-van der Snoek 1987) en voor de aanwezigheid van objectiveerbare chronische aandoeningen (van den Bosch. Habbema, vam der Maas e.a. 1988). De gevonden relaties zijn stabiel en geldig, ze doen zich in elk van de verschillende steekproeven van de Nederlandse bevolking voor. De gepresenteerde coëfficienten zijn inderdaad laag en een verklaarde variantie van rond de $20 \%$ geeft aan dat er nogal wat ruis in de hier gepresenteerde modellen zit of dat nog belangrijke verklaringen woor gezondheidsverschillen niet in het model zijn opgenomen. Dit heeft evenwel ook te maken met de gekozen onderzoeksmethode: secundaire analyse op bestaande surveys. Daarmee rekening houdend is de sterkte van de hier gevonden relaties vrij goed (Verbrugge, 1989). Als bijvoorbeeld wordt nagegaan welke bijdrage de kenmerken van klasse, status en burgerschap leveren aan het beter beschrijven van het aantal chronisch zieken dan blikt uit de logistische regressieanalyses, dat deze kenmerken de beschrijuing met 20 a $25 \%$ verbeteren": 2 tot $5 \%{ }^{2}$

Berekend als het aantai coor het ultgebreide model goed geclassificeerde respondenten op het totaal aantal goed geclessificeerde respondenten

(lcomect 
meer respondenten worden correct aangewezen als wel of niet chronisch ziek. Wanneer wordt uitgegaan van 4,5 miljoen hoofden van huishoudens naar wie deze resultaten mogen worden gegeneraliseerd, gaat het on 100 200 duzend mensen. Zelfs indien de kosten van een chronisch patient, te laag, op slechts 1000 gulden per jaar worden geschat, vertegenwoordigen de effecten van de kennerken van klasse, status en burgerschap kosten ten bedrage van 100 a 200 miljoen gulden. Alleen al om economische redenen is het van belang le pogen wia gerichte maatregelen de oorzaken van deze kosten te beinwloeden.

\section{b}

Thema's voor beleidsmaatregelen

Gezondheid en klasseverschillen: Tot welke socialle laag men ook behoort, bewoners van kwalitatief sllechte huizen en uitwoerders van vies, glevaerlijk of stinkend werk, zijn over het algemeen ongezonder dan degenen, die in gunstiger omstandigheden wonen en werken. Voor mensen in de lagere sociale klassen is het moelijk, waak onmogelijk om zich aan ongunstige woon- en werkornstandigheden te onttrekken of deze ten goede te veranderen. Het is daarom te verwachten dat nog steeds aanmerkelijke gezondheidswinst voor de bevolking is te behalen door regulatie van de woningmarkt, vooral waar het gaat om het bouwen van kwalitatief goede en betaalbare woningen en de toewijzing daarvan aan financieel zwakke huishoudens, als ook door controle op de kwaliteit van de arbeidsomstandigheden. De politieke aandacht, met name van socialistische en sociaal-democratische zijde, voor volkshuisvesting en arbeidsomstandigheden ten behoeve van de lagere socilale klassen en de maatschappelijk zwakkeren in de semenleving, heeft nog niet aan belaing ingeboet. Het is eerder verbazingwekkend dat zelfs in de jaren zeventig en tachtig deze onderwerpen nog belangrijk zijn als het gaat om de gezondheid van de Nederlandse bevalking. Uit het oogpunt van de volksgezondheid lijkt beleid dat is gericht op de terugtrekking van de overheid uit de woningmarkt en het afschaffen van huursubsidieregelingen een stap terug te zijn. temeer omdat uit nieuw onderzoek blijkt dat de omstandigheden waaronder kinderen opgroeien van invloed zijn op hun latere gezondheidstoestand (Rahkonen, Lahelma, Huuhka 1994).

Vermindering van aandacht voor de omstandigheden waaronder mensen werken, om daarmee de concurrentiepositie van bedrijven te verbeteren, is met het oog op de gezondheid van werknemers en de daarmee gepaard gaande kosten, op lange termijn kortzichtig beleid. De massale werkloosheid en de noodzaak tot flexibilisering van de arbeild leiden ertoe dat mem de starheid van de arbeidsmarkt wil doorbreken. Indien flexibilisering zou inhouden dat het toezicht op arbeidsomstandigheden zou verslappen en de bestaanszekerneid zou afnemen. heaft dit zijn prijs in de gezondheid van de werknemers. Anderzijds kan flexibilisering ook worden gezien als maatwerk, waarbij de behoefte van bedrijven en individuele werknemers meer op elkaar worden afgestemd; daarbil staan niet besparingen op de vaste arbeidskosten voorop maar de binding van mensen aan een bedriff om hun specifieke vaardig-en kundigheden optimaal te benutten. Zoals ooit in de haven de stuwadoors onderling all naar gelang hun leeftijd onderling taken verdeelden, zou het juist vanwege de automatisering, mogelijk moeten zijn produktiemprocessen af te stemmen op individuele mogelijkheden.

Gezondheid en status-verschillen: Aspecten vain status, zoals geloof en politieke voorkeur, markeren niet alleen individuele waardennariëntaties. Zij laten vooral zien dat opvoeding en levenshouding van specifieke groeperingen diepgaande invloed hebben op de manier waarop hun leden in hett leven staan. Zelfs wanneer de oorspronkelijke geloofsinhouden of ideologieên

a Het aantal respondenten dat door het uitgebreide model goed wordt geclassificeerd als percentage van alle respondenten

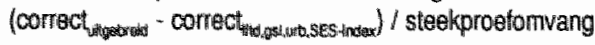


zin vervaagd, blijwen deze culturele verschillen in houdingen en gedragingen traceerbaar. zoals bijvoorbeeld tot uiting komt in het drinkgedrag van mensen, die zichzelf niet meer tot een kerkgenootschap rekenen. Hun drinkgedrag schint meer te likken op het drinkgedrag wan de leden van het kerkgenootschap waarin ze zijn opgevoed dan op dat van anderen (Knibbe 1993; mondelinge mededeling). In een pluriforme samenleving ligt het niet erg voor de hand de owerheld te adviseren pogingen in het werk te stellen om mensen tot een bepaald geloot te bekeren. Wel verdient het aanbeveling na te gaan welke mogelijkheden er zijn om, bijvoorbeeld via het onderwijs, een seculiere variant van de karakteristieke protestantse levenshouding. namelijk autonomie van het individu, reflectie op de eigen opvattingen en houdingen en verantwoordelijkheid voor het eigen gedrag, to bevorderen. Opgemerkt moet worden dat bevordering van de eigen autonomie niet mag worden gelijkgesteld aan of verward met verdergaande individualisering. De individualisering, zoals deze de laatste decennia in de Nederlandse samenleving is voortgeschreden, houdt met name in dat bij het nemen van beleidsmaatregelen rechtstreeks het individu wordt aangesproken en dat weinig rekening wordt gehouden met het sociale verbanden (zoals het gezin) waarin het leeft. Deze benadering heeft als gevolg dat deze verbanden institutioneel niet worden ingebed en bestendigd, wat valt te betreuren vanuit de wetenschap dat samenleven tegen ongezondheid beschermt. Eenzelfde trend valt waar te nemen in de voorlichting over gezond gedrag (voeding, bewegen, roken. drinken). Ook daar worden mensen benaderd alsof ze geen deel zouden uitmaken van een samenlevingsverband of gemeenschap. In de huidige nadruk op de gevolgen voor de gezondheid van de individuele leefwilize wordt veelal woorbij gegaan aan het collectieve karakter van veell riskante gewoonten, zoals alcoholgebruik, ongezonde voeding. Het is de vraag of preventieve programma's moeten worden gericht op de aanmoediging of ontmoediging van specifieke gedragingen. Afgezien van het feit dat die specifieke gedragingen deel uitmaken van eem gedragspatroon (mensen eten geen vet, ook geen etenswaren, maar maaltijen of tussendoortjes, waarvan tijdstippen, samenstelling en variatie aan bepaalde regels zijn onderworpen), houden zij ook verband met een algemene levenshouding waarin men zich wel of niet verantwoordelijk acht voor zijn handelen en de gevolgen er van. Campagnes, die er op zjin gericht de schadelijke aspecten van specifieke gedragingen onder de aandacht te brengen of gezond gedrag te propageren, zouden moeten worden geflankeerd en ondersteund door maatregelen. die beogen de autonomie en de eigen verantwoordelijkheid van de burger voor zijn levenswandel en zijn gemeenschapszin te versterken en mogelijkheden te creèren deze autonomie en verantwoordelijkheid ook daadwerkelijk vorm en inhoud te geven.

Daarbif is in eerste instantie te denken aan consistentie van en in beleid en aan heldere en doorzichtige uitvoeringsregels. Voortdurende wisselingen van beleidswoornemens en voortdurende aampassingen van beleid zonder dat dearvoor de noodzaak duidelijk is, mag dan wol appelleren aan de flexibiliteit en aanpassingsgerichtheid van het overheidsapparaat, hot maakt de overheid voor de burger tot een onbetrouwbare partner. Anders dan bij de meeste produkten die doorgaans gemakkelijk andere leveranciers kunnen worden gevonden, is het voor de meeste burgers niet mogelijk zich bij ontevredenheid eenvoudigweg tot een andere gemeente te wenden die beter aan zijn wensen voldoet dan wel te emigreren. Juist door het monopolie van de overheden is de duurzaamheid en woorspelbaarheid van hun dienstverlening van belang.

De verwachting is dat Nederland in de komende jaren een irmmigratieland zal bliven voor mensen die om politieke of economische redenen hun land onivluchten. Hoewell deze studie is gebaseerd op gegevens van Nederlanders, kunnen wit de resultaten ook principes voor het beleid jegens wuchtelingen en asylzoekers worden gedestilleerd. Indien deze nieuwkomers inadequaat worden gehuisvest en onbeschermd (illegaal) op de arbeidsmarkt participeren en geen politieke vertegenwoordiging kennen, hun sociale en culturele leven niet wordt gestimu- 
leerd, wordt de prijs daarvoor met gezondheid betaald. Het ruimhartig verlenen van burgerrechten aan deze nieuwkomers en het verduidelijken van de condities waiaronder deze rechten worden verleend, maakt hen weerbaarder en maakt het hen gemakkelijker in te burgeren.

Gezondheid en verschillen in burgerschap: De geconstateerde positieve invloed van burgerm schap op gezondheid wettigt de verwachting dat versterking van maatschappelijke verbanden en stimulering van saciale participatie bescherming bieden tegen factoren die de gezondheid bedreigen. Indien het aanbod van onderwijs wordt vergroot, maar mel als gevolg dal de klassen groter worden en er minder tijd en menskracht is voor aandacht voor individuele leerlingen, voor buitenschoolse activiteiten en voor toezicht, kortom dat het accent steeds meer verschuift van vorming naar opleiding, betekent dit dat de jeugd in belangrijke mate de aetening in burgerschap wordt onthouden.

Behalve voor het onderwijs, voor politieke partijen en vakbonden is in dit verband een taak weggelegd voor het buurtopbouwwerk, voor het sociaal-culturele werk en het verenigingslewen. Het behoort tot de verantwoordelijkheid van de overheid deze organisaties en activiteiten, o.a. door financiële steun, te stimuleren en te faciliteren. Ook hier geldt dat uit het oogpunt van de volksgezondheid de overheid, in plaats van te bezuinigen, in de sectoren welzijn en cultuur zou moeten investeren.

\subsection{Epiloog}

De schets, in de inleiding van dit boek, van de verschillen in gezondheid tussen rijken en armen in vroegere perioden wan West-Europese samenlevingen, beoogde te illustreren hoeveel er in de loop van zo'n honderd jaren is veranderd en hoeveel tegelijkertijd er gelijk is gebleven. Enerzijds is de gezondheidstoestand van de lagere sociale lagen zo sterk verbeterd en zijn de verschillen met de hogere sociale lagen zo ver gereduceerd, dat de vraag rijst of het zinvol is deze nog verder te onderzoeken. Anderzijds lijken er in de huidige Nederlandse samenleving, ondanks de in de jaren zestig en zeventig gevoerde nivelleringspolitiek, nog steeds klasseverschillen te bestaan, die een naar verhouding belangrijke oorzaak vormen van een minder goede gezondheid in de lagere saciale lagen. De ongerustheid van Thorbecke over een "onoverklimbare grens tussen bevoegden en onbevoegden" of in het hedendaagse jargon 'een tweedeling van de samenleving" is nog actueel, ditmaal misschien niet alleen op grond van liberale overtuiging, maar ook vanwege de kosten die voortvloeien uit de werslechtering van de gezondheid wan mensen die in de positie van tweederangs burger worden gerangeerd, ironisch genoeg omdat ze genoodzaakt zijn hun burgerschapsclaims op te eisen.

De verbetering van de gezondheidstoestand van de Nederlandse bevolking ten opzichte van anderhalve euw geleden is grotendeels toe te schrijuen aan maatregelen die beoogden het lot wan mensen in de onderste klasse te verbeteren. In de resultaten van deze studie komt naar voren dat de daarbij beproefde, concrete beleidsmaatregelen, nog niet aan belang hebben ingeboet. Werk onder behoorlijke omstandigheden, adequate huisvesting en deelname aan het sociale , politieke en culturele leven bliken, ondanks al de veranderingen die in de laatste eeuw zijn opgetreden in de Nederlandse samenleving nog steeds van essentieel belang woor het welzijn van haar burgers. De prijs die voor een terugtredend beleid op enig van deze punten wordt betaald is de toekomstige gezondheid van de bevolking. 


\section{SUMMARY}

The central theme of this book is the unequal distribution of illness and disease in the population, and more specific, the mechanisms that underlie and explain socio-economic differences in health.

Although inequities in health have been observed since long. the explanation of this phenomenon is still far from clear and often coloured by ideological overtones. Inequalities in health have either been attributed to poverty, to differences between the social classes in housing and working conditions or to differences in social status and lifestyle, that is to inadequacies in contorming to culturally and socially accepted standards of behaviour, to lack of temperance and to differences in diet and the (mis) use of alcohol and tobacco. Some have denied the existence of socio-economic differences in health, proclaiming it as an artefact of the conception of social stratification that is based on occupational status and therefore does not include those who are not active on the labour market. Others believe that inequality in health is the unavoidable result of processes of social selection.

At macro level socio-economic health differences appear to be related to the structure of society and to social differentiation. Countries in which income has been redistributed to a relative high degree, like the Scandinavian countries and the Netherlands, have healthier populations than countries marked by a sharper cleavage between rich and poor. Very poor countries that succeed in securing local labour markets by subsidizing jobs for the improvement of the infrastructure in times of aridity and economic hardship, have healthier populations than richer countries that do not prevent people from migration because of famine, temporary unemployment or war.

Over the last decade new studies have shown that, on the individual level, factors like poverty. economic hardship and unemployment are related to ill health, especially if people are confronted with these conditions in childhood. The setback seems to begin al conception and is difficult to overcome. Economic hardships appear to explain inequalities in health better than does lifestyle or behaviour. Still, there is plenty of evidence that behaviours, generally thought to be associated with differences in social status, such as the consumption of harmful commodities (fatly food, tobacco, alcohol), lack of physical exercise, underutilisation of health care, are linked to illness and disease.

There is, however, no consensus regarding the autonomous etiological slatus of the behaviourial factors. Some see these behaviours as indicators of other, materialist conditions which are more straightforwardly related to the class structure of sociely, such as hard, exhaustive work. low income, lack of prospectives, poor knowledge. Parties in this dispute all claim empirical evidence for their point of view. In fact there is hardly any research in which the independent contributions of materialist conditions and cultural lactors to the explanation of socio-economic differences in heaith have been analyzed. It is the main purpose of this study to combine the various approaches in one model and to asses their relative importance for the understanding of health differences between social strata. Financial support of the Ministry of Welfare. Public Health and Culture made this study possible. 
In CHAPTER 1 the main theme of the study is introduced. It opens with a short historical overview of socio-economic and cultural developments in Europe. especially in the Netherlands and the persistent, ever present social gradient in health. It is concluded that in spite of the political emancipation of the lower classes, greatly improved economic conditions. social security and an advanced, accessible health care system health differences have remained. In some cases, as was pointed out for England in the Black Report, health differences between the upper and lower strata even widened during the latter half of this century. Although of course less poignant than in the $19^{\text {th }}$ century, the chances on good health and longevity are unequally distributed among the classes. It is, of course, an intriguing question why despite all the blessings of a democratic welfare state in the lower classes chances to all kind of diseases and mortality rates are still higher than in the higher classes. Evidently sheer poverty is not the only. most important condition to bring about these differences in health.

In this study health differences in the population are seen as a social phenomenon. Illnesses and diseases are caused not only by physical and biological agents "their onset and course are also determined through interaction with the social environment, and by beliefs and conceptions of health, which are linked lo the social structure and the value system of society. The explanation of social inequalities in health by differences in lifestyle easily leads. to a 'blaming the victim" if it ignores the social and cultural embedding of food choice, drinking of alcohol, physical exercises and other health related behaviours.

It is argued that, in addition to the classic explanations of socio-economic differences in health, i.c. material life chances and lifestyle, indicators for social integration and participation should be included in the model.

The aim of the study is threefold:

a) to assess the independent contributions of materialist conditions and cultural factors to the explanation of socio-economic differences in health as well as the cumulated and interaction effects of both categories of causal factors on the social stratification of health:

b) to ground these supposed mechanisms of the relation between socia-economic status and health in sociological theories of social stratification and to link them to the concepts of class and status;

c) to expand the explanatory model with the concept of citizenship and to assess its relevance for the underslanding of socio-economic health differences.

The chapter closes with a discussion of some methodological problems and pitfalls that should be taken care of in the design of the study.

In CHAPTER 2 the main concepts of the study are defined and its most important proposilions are formulated.

To describe social stratification sociological theory offers four concepts that reflect different points of view regarding its causes or legitimation:

Estate reters to ascribed differences on basis of personal characteristics such as race. birth, age and gender. In this study age and gender are conceived as indicators of estate. Apart from their biological meaning, age and gender also stand for ascribed social identities that control access to many positions in society.

Class refers to differences between people based on unequal access to scarce resources. Class determines the distribution of favourable living conditions and the ability to avoid or overcome adverse living conditions.

Status differentiates between social categories with different social prestige that is 
based on their contribution to society or the efforts of the incumbents lo acquire their position in the social structure. If implies differences in knowledge, in ability to understand the intricacies of social tite and to behave in a responsible and meaningtul way.

Citizen- defines differences between social categories as a function of the various legal, ship political and social rights and claims they hold on society and on the state in particular. It refers to differences in social participation and possibilities to control one's own late.

These concepts are considered to represent the mechanisms that underlie the unequal distribution of scarce goods such as power, prestige, wealth, and in the context of this study. also of health. As social differentiation is almost always related to education. income and social grouping or profession, class, status and citizenship are inevitably all influenced by these basic factors of social differentiation. For the purposes of this study it is therefore important to specify a common denominator of social differentiation (SES-index) based on these principles, and to describe class, status and citizenship independent of these common characteristics. In that way it will be possible to test the effects of the mechanisms implied in these concepts.

The concept of health is defined in terms of subjective and self-reported bodily experiences and complaints. Three aspects of subjective health are distinguished that a) signify valid representations of a person's state of well being, b) have been shown to be closely related to medical conceptions of health (symptoms and diseases), and c) are unequally distributed among the socio-economic status categories:

1. Chronic ailments or disabilities,

2. Perceived health,

3. Experienced health. as the possibility to perform activities withoult physical disturbances

as the perception of the strength of one's body regardless the presence or absence of complaints or ailments

as the evaluation of one's physical state in terms of physical complaints.

Before the model which speciftes the relations between class, status and citizenship and health can be put to a test, it has to be checked whether health differences are antifacts ol gender and age or the result of processes of selection and drift. In case of selection. people are trapped in a social position because their (chronic) ill health prevents them from climbing, while drift is al work when ill health causes a person to descend the social ladder. At the end of the chapter five propositions were tormulated:

1. The relationship belween the common denominator of class, status and citizensthip (SESindex) and subjective health, can be fully described by the effects of gender and age. (Health differences as an artefact effecl).

2. There exists a relation between the common denominator of class, status and citizenship (SES-index) and the presence of chronic ailments, under the condition of controlling for the effects of gender, age and subjective health experiences. (Health differences as effect of selection and drift). 
3. Under the condition of controlling lor effects of age, gender and the common denominator of class, status and citizenship (SES-index). class, status and citizenship have independent effects on subjective health (Health differences as consequences of social differences in materialist conditions, lifestyle and social participation).

4. The relations belween age and gender on the one hand and subjective health on the other, disappear under the condition of controlling for all indicators of social differentiation. (Age and gender are only indicators of estate).

5. The relationship between social differentiation on the one hand and subjective health on the other is explained either by the cumulation of indicators of class, status and citizenship, or by the social inconsistencies in these indicators.

CHAPTER 3 entails the description of data sets and methods used in the analyses. The data sets are based on national surveys on the quality of life of the Dutch population' in 1974 . 1977,1980 and 1983 of the Central Bureau for Statistics and the panel study on health and health behaviour of the Dutch population in 1981 and 1983 of the University of LimburgMaastricht. The surveys used random samples of the Dutch population older than 17 in the year of study $(\mathrm{N}=6000)$; the random sample of the panel study was restricted those between 18 and 65 of age in $1981(\mathbb{N}=2000)$. The non-response rate varied from $28.2 \%$ in 1974 to $42.2 \%$ in the 1983 panel.

To ensure a complete measurement of socio-economic status the anallyses were restricted to heads of households. By consequence the samples are representative for Dutch males, but not for females, as the number of women active on the labour market has been rather low in the Netherlands: in the samples $80 \%$ of the head of households is male. On the average the surveys count about 1750 heads of households, the panel study contains 499 heads of households with complete data. The age range varies from 20 to over 90 years, with the median around 43.5 year.

Chronic ifmess is operationalized as 'yes' on the question whether one suffered from a lang standing disease or illness, perceived health is rated on a 5-point scale (excellent 5 - very bad 1), comparing one's health with that of other persons and experienced health has been measured as the number of physical complaints on the Inventory of Subjective Health (13. item version). These instruments have proven to be reliable and valid measures of subjective health and are closely related to conditions of illness and disease as defined in medicine.

On the average, perceived heaith was rated as good (4), the number of complaints was about 2 to 3 and about a quarter to halt of the heads of households reported to suffer from chronic conditions.

Class has been indicated by working and housing conditions and the possession of durable consumer goods. Social status is described by religious and political conviction, free time activities and risky habits, like smoking and drinking alcoholic beverages. Marriage. membership of voluntary organizations, volunteer work and use of social services indicale cillizenship.

To overcome the problem of different phrasing of questions from one survey year to another. and the rather different phrasing of questions in the panel study, indexes were devised to measure class, status and citizenship. These indexes are based on optimal scaling lechniques when the questions had more than 2 categories (HOMALS), and on probabilily scaling according to MOKKEN and principal components analysis (PCA) if they were coded binary. The data of the survey 1983 have been used to develop the scaling models and for the calculation of the various weights and coefficients. These were applied in the calculation of the indexes for the various data sets. 
Most hypotheses were tested with hierarchical OLS regression (perceived and experienced health) and logistic regression (chronic allments).

To test the first hypothesis the differences in the contribution of age and gender to the explanation of health were evaluated through analyses, that besides region and degree of urbanization included either or not the SES-index (base model).

The second hypothesis was tested by the partial correlation between the SES-index and chronic ailments, controlled for age, gender and perceived and experienced health.

The third hypothesis was tested in two ways. First, the contribution of the SES-index to the explanation of health differences was analyzed with the introduction the indicators of class. status and citizenship separately. Then the indicators of the three concepts were introduced together in the analysis (the SEGV model). The different contributions of the SES-index in the separate and joint analyses were evaluated. Second, the change in the relationship between the SES-index and subjective health, before and after the introduction of the three modeis in the analysis, was determined.

The fourth hypothesis was tested by hierarchical regression. The contribution of gender and age in the base model and in the SEGV model was evaluated. The last hypothesis was tested in the same way by introducing indicators of cumulation and social inconsistency into the SEGV model.

The procedures and results of the index construction are reported in CHAPTEA 4. The common denominator of education, income and social grouping (SES-index) correlates highly $(>.80)$ with achieved educational level ${ }_{\text {, }}$ and has a positive relation with income ( $r \approx 79$ ). inspection of the relationship reveals that the lowest income groups have unreliable SESscores, due to students and pensioners (high education, low income) or social desirability. Heads of households that are housewife or who are on disablement pension have the lowest scores on the index, while high employees and those in the professions have the highest scores. It is shown that the optimal scaling techniques produce highly comparable results in the various data-sets in spite of the different phrasing of the questions.

In CHAPTER 5 the results of the various analyses are described. First it was determined whether the inequities in health have increased during the period studied. The concentration-curves show a light increase in socio-economic health differences from 1974 onwards for all indicators of subjective health. However, these differences are not very large.

The artefact hypothesis could be rejected. It appears that the SES-index contribules significantly to the explanation of variance in subjective health. even if age and gender are controlled for.

The hypothesis of drift and selection could also be rejected. Should selection and drift play a significant role in the causation of socio-economic health differences, than it could be expected that those who report a chronic condition will also belong to lower SES-strata. This relation would be indicated by a substantial correlation between SES-index and chronic illness, when controlled for age. gender, and perceived and experienced health. However. the partial correlation is 0 , indicating there is no relationship at all

The hypothesis that the effects on health of class, status and citizenship can be distinguished from those the common denominator of social differentiation (SES-index) could be accepted. When controlled for age, gender, region, urbanization and SES-index, class, status and citizenship still explain substantial variations in subjective health. Class has the highest contribution ( $1-5 \%$ explained variance), followed by status (1-3\%) and citizenship $(5-3 \%)$. 
As fife-situation, lifestyle and social participation are interrelated. they might indicate the same mechanism to produce ill health. In that case, their joint effect would be lower than the effect of the separate analyses. This is not the case, thus class, status and citizenship do imply different mechanisms in the production of ill health.

However class, status and cilizenship as distinct mechanisms of social differentiation, might be the only markers of social differentiation and together represent socio-economic status. In that case, the retation between the SES-index and health should disappear when indicators of class, stalus and citizenship are introduced in the analysis simultaneously. This appears not to be the case. Careful inspection of this relationship, though, reveals that introduction of class and status indicators lowers the relationship between the SES-index and health, whereas inclusion of citizenship increases the correlation between SES-index and subjective health. It is concluded that class and status are directly responsible for inequities in health, and that citizenship appears to protect against ill effects of social differentiation.

The class indicators housing and working conditions, are clearly related to health status, as are the status indicators religious conviction, political preference, use of alcohol and participation in sports. Catholics, who vote left wing parties and drink alcoholic beverages without doing sports, appear to be less healthy than right wing protestants who sport and abstain from alcohol. Creative free lime activities like making music, being member of a choir or acting. support good health. whereas using services for individual counselling is inversely related with good health.

The hypothesis that age and gender are sole indicators of estate and as such indistinguishable from social differemtiation had to be rejected. Although the relations between the two indicators and health decrease when the SES-index is introduced in the analysis, their effect does not become insignificant. Moreover, when indicators of class, status and citizenship are introduced in the analysis, the relations between age and gender with health increase, which finding indicates that the effects of class, status and citizenship are nof equal for men and women, nor for younger and older people.

In CHAPTER 6 the relation between social differentiation and subjective health is further explored by testing the hypothesis that either the cumulation of health hazards in class, status and citizenship. or social inconsistencies in characteristics of class, status and citizenship are in fact responsible for the relation between class, status and citizenship as specitied in the models mentioned earlier. This thypothesis had to be rejected. Neither curnulation of effects nor social inconsistencies do change the findings of chapter 5 . However, it appears that cumulation and social inconsistency each have a small, independent effect on health slatus ( $1 \%$ explained variance)

Surprisingly, bad housing and working conditions together had no a greater effect on ill health than these indicators had separately. nor was the combined effect of smoking and heawy drinking stronger than the separate effects of these behaviours. Howewer, abstainers perceived and experienced their health as better than those who use these substances. although among the abstainers there are more persons with chronic ailments. The negatwe effects of smoking and heawy drinking, are overruled by the effects being active in free lime: irrespective of smoking and drinking, the health of persons who spend their free time actively are healthier than those who spend it in a more passive way. Consequently, membership of sporting clubs and cultural organisations improves health. People who use social services and consult social councilors and assistants report a better subjective health than those who use only one of these services; but there are more persons with a chronic ailment among the first than among the lalter. 
The finding of the health promoting effects of sport and cullural activities could be interpreted as the result of selection. Those who are able to sport, to act and who pass their free time actively, are also in a better shape. The survey method offers no possibility to decide beiween the alternative interpretations. Most likely it works both ways: people whose health permits them to engage in sports and other activities, feel better when they in lact exercise these abilities and live an physically and mentally active life.

Social inconsistencies have a clear relation with health, as is to be expected from literature on this subject. However, it appeared that whereas indeed some inconsistencies were negatively related to health, others correlated positively with health. Only inconsistencies in indicators of the SES-index and in the use of social services show a significant negative relation with health. Inconsistencies in voluntary activities, memberships of organisations and in work and housing conditions are positively related to health. These findings necessitate a refinement of the hypothesis that social inconsistencies have an ill effect on health. Only those inconsistencies that are forced and not voluntary sought, are harmful. Voluntary sought inconsistencies may have positive consequences for health.

In CHAPTER 7 the results of the study are summarized. Although in the Netherlands the socio-economic differences in health are not very large, they have accrued belween 1974 and 1983. The differences are the smallest for perceived health and the greatest for experienced health and chronic disabilities. These differences in health cannot be altributed to demographic and geographic factors, nor to differences in degree of urbanisation. Neither can they be attributed to procesises of drift and selection.

Class, status and citizenship each have an effect on subjective health, independent of the common basic characteristics of social differentiation as indicated by the SES-index (education, income and occupation). Class, status and citizenship prowide complementary explanations for inequalities in subjective health. Class and status explain partly the offect of the SES-index on health, citizenship seems to offer some protection against the negative effects of class and status. The physical consequences of aging do not depend on one's position in sociely. However, class, status and citizenship accentuate or decrease the effects of aging on experienced health and chronic illness. Differences between younger and older persons in perceived health can almost completely be described as effects of class, status and citizenship.

Cumulation of health hazards or risky lifestyles could not be demonstrated in the data. It is more likely that chronic ailments restrict behaviourial choices. Social inconsistencies that are imposed are health threatening. but social inconsistencies that have been chosen voluntarily could have a positive effect on health. This finding implies a refinement of the present theories on the relation of social inconsistencies with health.

Although the findings are exclusively based on measures of subjective health, they have wider implications because the indicators used, do to a large extent cover what is usually meant by health and disease in medicine. Moreover the correlations found probably underestimate the real relations because of the selection bias in surveys. As a rule samples of surveys and panel studies will consist mostly of cooperative. literate, respectable citizens and hardly include people who are the most exposed to all kinds of health risks and go without the protection of citizenship. such as the homeless, alcoholics, drug addicts, mentally unstable or other persons living in the margins of society because they cannot be reached or are inclined to refuse cooperation. 
Some more drawbacks of the survey method in research into socio-economic health differences are discussed in CHAPTER 8 . It is concluded that both qualitative research, especially 'case history studies', and longitudinal studies are needed to get more detailed intormation on the processes involved and on the causality of the relations between the various aspects of social stratification and health.

This chapter also discusses the implications of the findings for social theory and for policy. The results regarding social class seem to support an exposition model, although no cumulation effect could be detected. They point to unfawourable housing and working conditions as causes for inequalities in health. Differences in access to scarce resources or economic hardship do vary the degree of exposition to these factors or limit the possibility to avoid it.

The relation of heavy drinking with heallh also seems to support the exposition paradigm. It is difficult, however, to reconcile religious conviction and political preference with this model. It might theretore be more likely that the effect of social status on health has to be understood in a Durkheimian vein: protestants might be more healthy regardless social differentiation because they have internalized societal (middle class) norms and values and therefore are more self-contident than Roman Catholics who for their identification depend more on others. The higher prevalence of ill health of left wing voters could than be a consequence either of lack of confidence in the ability to maintain oneself as an independent member of saciety or of selection. Should the Durkheimian interpretation be correct. than social status might be related to ill health through chronic stress that in the long run affects the immunological apparatus. The findings with respect to the inconsistencies could easily be encompassed in such a model.

In either model, the protection of citizenship against ill health will need further elaboration as its relationship to distress is not entirely clear. In essence, citizenship refers to the condition that within the boundaries of national law, each individual is free to control his own life. Civill citizenship specifies the juridical conditions, political citizenship guarantees the individual access to decision making and social citizenship creales the social en economic conditions to do so. These formal aspects of citizenship have to been realized in daily life, citizenship has be acquired; it requires competent individuals who know what they are doing, who can envisage what is the impact of their acts and who understand their relations to the acts of their fellow citizens. These three requirements of citizenship are analogous to the three characteristics of coping as defined in Antonowsky's "sense of coherence:. People that have a high 'sense of conerence" do understand their responsibilities, have the idea that they can manage these responsibilities and that their responsibilities and actions are important.

In this analogy, citizenship appears to be a pivot between social structure and the individual. The established cilizenship of an individual implies his or her societal position among others with the same possibilities, as well as his or her individual coping capacities.

The results of this study support the idea of a modern democratic welfare state: irrespective of the quality of the health services, the health of the population is furthered by the protection of individuals against economic hardship and exposition to health threatening conditions at work and at home. Theretore, the government should monitor healthy working and housing conditions and should safeguard the access of high quality education for all its citizens. Moreover, the government should promote the participation of its citizens in the sports and the arts and further the full realization of their citizenship. As the health status of many people in the Dutch population depends at least partly on class, status and citizenship, it can be callculated that the realization of these goals could spare hundreds of millions Dutch guilders in health care expenditure. 


\section{LITERATUUR}

Abel, T. (1991) "Meassuring Health Lifestyles in a Comparative Analysis: Theoretical Issues and Emperical Findings' Social Science \& Medicine 32: 899-908.

A.bel, T. MoQueen,D.V. (1994) 'Determinants of selected urhealthy eating behaviours among male and female adults'. European Journal of Public Health 4. 27-32.

Adriaanse, H., M.J. Drop. R. Hallens, H. Philipsen (1981) Leeft Nederland Oké? Verslag van een onder." zoek naar de beleving. opvattingen en gedragingen inzake gezondheid. Maastricht: RL

Adriaansens (1994) "Citizenship. Work and Welfare" in: van Steenbergen (ed.) The Condition of Citizenship Londen: Sage

Alach, P. R. Carr-Hill. S. Curtis $s_{n}$ R. Illsiey (1987) Les inegalites sociales de sante en France ot on Grande-Bretagne: analyse et etude comparative. Parijs: INSERM.

Annandale $E_{.}$. K. Hunt (1990) 'Masculinity, femininity and sex: an exploration of their relative contribution to explaining gender differences in health.' Soclology of Health \&. IIIness. 12.

Arnizen, A., Samuelsen, S., Magmus, P. Bakketeig, L.V. (1994) 'Birth weight related to social indicators in Norway. European Journal of Public Health 4:92-97.

Bakker, B. (1985) 'Sociaal Milieu en Culluurdeeiname: een nadere tootsing van Ganzebooms informatietheorie.' Mens en Maatschappil 60:162-177.

Bakker, B.F.M., J. Dronkers, J.G.W. Meijnen (eds.) (1989) 'Educalional opportunittes in the welfare state: longitudinal stadies in educational and occupational attainment in the Netherlands. 'W.M. Meijnen, J. Peschar, A. Wesselingh OOMOreeks Nimegen:ITS.

Baumann, B. (1961) 'Diversities in conceptions of health and physical fitness.' Health and Human Behavior 2: $39-46$.

Barber, B. (1957) Social Stratification; a comparative analysis of structure and process New York: Harcourt, Brace \& World.

Bendix, R. Lipset. S.M. (eds.) (1966) Class, Status and Power, social stratification in a comparative perspective. New York: Free Press.

Berkel- wan Schaik, A.B van. B. Tax (rapporteurs) (1990) Naar een standaardoperationalisetie van sociaaleconomische status voor epidemiologisch en sociaalmedisch onderzoek. Filswilk: Ministerie van WVC.

Berkman, Syme (1979) 'The Relation of Social Networks, Host Riesistance and Mortalty: A Nine-Year Follow-Up Study of Alamada County Residents' American Joumal of Epidemiology 190: 186-204.

Blane D. (1985) 'An assessment of the Black Report's "explanations of health inequalities'. Soclology of Health and illness. 7:423-445.

Blaxter, M. (1990) Health and Lifestyles Londen: Routledge.

Bos, G.A.M. van den, J.D.F. Habbema. P.J. van der Maas, J. Mohrs (1988) De leof- en zorgsituatio van chronisch zieken. Amsterdam: Instituut voor Sociale Geneeskunde, Universiteit van Amsterdam.

Bos. G.A.M. van den, M.E. Lenoir (1991) Sociale ongellkkeid in chronische aandoeningen, beperkingen an zorggebruik. Amsterdam:Instituut voor Sociale Geneeskunde, Universiteit van Amsterdam.

Bosch van den F.A.d., C. Petersen (1982) 'Gezondheidszorg en arbeidsongeschiktheid." Openbare Uitgaven. 14:37-54.

Boshuizen HC. Water van de HPA, Perenboom RJM. "Sociaal-economische verschillen in gezonde levensverwachting. TSG 1994, 72:122-127.

Bosma, H. A. Appels, F. Stumans, P. Mulder, U. Schuurman (1991) KRIS follow-up X: De invloed van de Sociaal-economische status van de vrouw op de levensverwachting van de man. verschillen in morbiditeit en mortaliteil gedurende een follow-up van circa 10 jaar.' TSG $69350-356$.

Bott E. (1954) 'The concept of class as a reference group." Human relations. 7:259-286.

Carmel S. Bernstein J. (1989) 'Trait-anxiety and sense of coherence: a longitudinal study' Psychol. Rep. 65: $221-222$. 
Camines, E.G., F.A. Zeller (1979) 'Reliabilty and validity assessment J. L. Sulivan (ed.) Ouantitative Applications tor the social sciences. 17 Beverly Hilts: Sage.

Carr-Hill. R. (1990) "The Measurement of Inequalities in Health: Lessons trom the British Experience" Social Science \& Medicine 31: 393-404.

CBS (1975) De leefsitwatie van de Nederlandse bevolking 1974, kemcifers Den Haag: Staatsuitgeweri. CBS (1978) De leefsituatie van de Nederlandse bevolking 1977, kemcijfers Den Haag: Staatsulgeverif.

CBS (1984a) De leofsituatio van de Nederlandse bevolking 1980, kernciffers Den Haag: Staatsuitgeverit.

CBS (1984b) De leefsituatie van de Nedorlandse bevolking 1983, kemciffers Den Haag: Staatsuitgevenij.

CBS (1990) 90 jaar statistiek in ciffers Den Haag: SDU

CBSHEUF. International Wariation in Socio-Economic mequalities in Self-Reported Hoalth. Den Haag: SDU 1992

Chenu, A. (1988) 'Sexe et mortalite en France, 1906-1980.' Riewue franc. sociol. 92:293-324.

Cipolla, C.M. (1976) Betore the Industrial Rewolution. European socioty and economy: 1000 1700. London: Mathuen (2 edition).

Coleman, R. (1978) Sockal Standing in America New York: Basic Books.

Culpht, 1. (1992) Welfare and Citizenship: Beyond the Crisis of the Welfare State? London: Sage.

Currer, C. M. Stacey (eds.) (1986) Concepts of Health, Wness and Disease: a comparative perspective. Leminglon Spa: Berg.

Davis, $N Z$ (1965) Society and Culture in early modern France Stanford: SUP

Deleeck H. (1988) "Het Mattheuseffect in de gezondheidszorg. een woorstel tot de verktaring van sociale ongelijkheden." Tijdschrift voor Sociale Gezondheidszorg. 66:325-328.

Diderichsen, F. (1990) "Health and social imequities in Sweden. Soc.Sci.Med. 31:359-367.

Dlederiks J.P.M, J. Joosten, F.J.M. Vlaskamp (1991) 'De sociale constructie van handicap.' In: G.W. Aakster, G. Kuiper, J.W. Groothoff (red.) Medische Sociologie. pag.113-120. Groningen:Wolters-Noordhoff, geheel herziene $4^{*}$ druk.

Dirken, H.M. (1967) Het meten van industriele stress. Groningen: Wolters.

Dohrenwend. B.S. Dohrenwend. B.P. (1981) Stressful Life Events: Their Nature and Effects. New York: Prodist.

Dresster, W. (1988) "Social Consistency and Psychological Distress'. Journal of Health and Social Behavior 29:79.91.

Dressler, W. (1990) 'Lifestyle, Stress and Blood Pressure in a Southem Black Community'. Psychosomatic Medicine 52: 182-198

Dressier, W. (1993) 'Social and Cultural Dimensions of Hypertension in Blacks: Underlying Mechanisms.' in: Fray, J.C.S., Douglas, G. Pathophysiology of Hypertension in Blacks New York: Oxford University Press.

Dressler. W. (1993) 'Type A behavior: contextuall effects within a southern black community'. Soc.Sc.\& Med. 36: 289-295

Drop M.J. (1979) "Arbeidswerdeling. normakive integratie on typen wan afwijkend gedrag." . Maastricht:Dissertatie, Rijksuniversitelt Limburg.

Drop M.J. (1991) De maatschappelike betekenis van ziekte: In: G.W. Aakster, G. Kuiper, JW. Groothoff (red) Medische Sociologio. pag. 76-85. Groningen:Wolters-Noordhoff, geheel herziene $4^{\mathrm{e}}$ druk.

Drop. M. .. G. Houben (1984) 'Gezondheid en zlekte als maatschappelijke verschijnselen." In: C.W. Aakster. G. Kuiper (red) Leorboek Medische Sociologie. pag. 76-85. Groningen:86-98 Wolters-Noordhoff, getheel herziene $3^{\text {ds }}$ druk.

Edwards J.F. C.L. Cooper (1988) The impacts of positive psychological states on physical health: a review and theoretical framework: Soc.Sci \& Med. 27:1447-1459.

Ensel, W.N., N. Lin (19911) "The life stress paradigm and psychological distress." Journal of Health and social behavior 32:321-341

Ellison C.G. (1991) 'Religious Involvement and subjective well being.' Journal of health and social behavior. 32:80-99.

Epstein, A.M. J.A. Hall, J. Tognetti, L.H. Son, L. Conant (1989) "Using proxies to evaluate quality of life. Canthey provide valid information about patients" health status and satisfaction with medical care?" Med-Care. $27: 591.98$.

Everitt, B.S., G. Dunn (1983) Advanced Methods of data exploration and modelling London: Heinemann.

Flannery, AB. Flannery, GJ ("990) 'Sense of coherence life stress and psychologic distress: a prospective methodological inquiry", J. Clinical Psychiatry 46:415-420

Fox, R.C. (1981) 'The medicalization and demedicalization of American society. "Daedalus, 106:9-22.

Fox, J. (ed.) (1989) Health Inequalities in the European countries. Aldershot: Gower 
Fox, J.W. (1990) 'Social Class, Mental Ilimess, and Social Mobility: The Social Selection-Drlft Hypothesis for Serious Mental Illness.' Joumal of Health and Social Behavior 1990. 31:344-353.

Freidson, E. (1970) Profession af Medicine San Francisca Josey Bas.

Gadourek. 1. (1963) Riskante Gewoonten en de zorg voor eigen welziji Groningen: Wolters.

Galtung. J. (1967) Theory and methods of social research London: George Allen \& Unwin.

Ganzeboom, H., P. de Graaff, M. Kalmijn (1987) De culturele en de economische dimensie van beroepsstatus: Mens en Maatschappij. 2:153-175.

Geurts, P.A.TH. (1992) De maatschappelike betekenis van beroepsprestige Enschede: dissertatie UT.

Giddens. A. (1984) The constitution of society: outline of a theory of strucluration Cambridge: Polity Press.

Giddens, A. (1989) Sociology Cambridge: Polity Press:

Giff. A. (1981, 1990) Nonlinear Multivariate Analysis. Chichester: Willey

Graaf, H.B.G. de, N.D. Ganzeboom (1990) 'Cultuurdeelname en opleiding: een analyse wan statusgroepeffecten met diagonale referentiemodellen. 'Mens en Maatschappij. 65:219-24.4.

Grand, A., P. Grosclaude, H. Bocquet, J. Pous, J.L. Albarede (1988) 'Predictive value of life events, psychosocial factors and self-rated health on disability in an elderly rural french population." Social Sclence and Medicine. 27:1337-1342.

Grand, A. P. Grosclauide, H. Bocquet, J. Pous, J.L. Albarede (1990) Disability, psychosocial factors and mortality among the elderly in a rural French population." Journal Clinical Epidemialogy 43:773-782.

Grosveld, J.A.M. (1981), 'Arbeidsongeschiktheid, preventieve gezondheidszorg en organisatiepsychologie." In: F. Sturmans, J. Persoon, J Morshuis, R. Windhausen (red) Verkenningen in de socials geneeskunde. pag.135-154. Nijmegen: Dekker \& van de Vegt.

Gunning-Schepers, L.J. (1991) 'Sociaal-economische gezondheidsverschillen en overheidsbeleid." In: Wetenschappellike Raad voor het Regeringsbeleid Sociaal-economische gezondheidswerschillon on beleid. Preadviezen. pag.: 9-10. 's-Gravenhage:SDU.

Halfens, R. M.J. Drop. H. Philipsen (1983) Leefwizen en subjectieve gezondheid wan een panel uit de Nederlandse bevolking. Maastricht: RL.

Harris "R.J. (1975) A primer of multivariate statistics New York: Academic Press.

Haug, M., Lawton, M.P. (1981) 'Elderly pationts and their doctors." . New York: Springer Publishing Co.

Herzlich. C. (1973) Health and Ithess London: Academic Press.

Hill, S. (1990) "Britain: the dominant ideology thesis after a decade." In: N. Abercombie, S. Hill., B.S. Tumer Dominant ldeologies pag: $1-1-37$ London: Unwin Hyman.

Hoeven, P.J.A. ter (1963) Havenarbeiders van Amsterdarn en Rotterdam: Sociologische analyse van een arbeidsmarkt. Leiden: H.E. Stenfert Kroese

Hornsveld, H., B. Garssen, M.F. Dop, P. van Spiegel (1990) 'Symptom reporting during voluntary hyperventilation and mental load: implications for diagnosing hyperventilation syndrome." Journal of Pisychosomatic Research. 34:687-697.

Horst. F.G.E.M. R.J.G. Haltens, H. Philipsen, d. Joosten (1987) Werklozen, arbeidsongeschikten en vervroegd gepensioneerden; een vergelijking naar sociale participatie en gezondheld.' in: I.P. Sprult, F. Tazelaar (red.) Leven met werkloosheid pp.: 487-197. Groningen: Wolters-Noordhoff.

Horst, van deir, F.G.E.M. (1988) Gezondheid en niet werkon. Maastricht: Academisch Proetschrift, Rijksuniversiteit Limburg

d"Houtaud, A., M. Field (1984) 'The image of health: variations in perception by social class in a French population.' Sociology of Health and Illiness 6:30-60.

d'Houtaud. A. M. Field (1986) "New research in the image of health." in: C. Currer. M. Stacey (eds.) Concepts of health, illness and disease: a comparative perspective. Lemington Spa: Berg.

lilisley, R. (1986) 'Social mobility, selection and the production of inequalities in health' Q.J. Soc. Affairs 2. 213-223

ItIsley, R. (1990) 'Comparative review of sources, methodology and knowledge." Soc.Sci.Med. 31:229236.

Jacobson, D.E. (1986) "Types and timing of social support." Journal of Health and Social Behavior 27:250-264.

Joosten. J., M.J. Drop (1988) 'De betrouwbaarheild en vergelijkbaarheid van drie versies van de VOEG. Gezondheid en Samenleving 8: 251-265.

Joosten, J. (1988) "The structure of the concept 'Health' in the Dutch population." In: A. d'Houteud. M.Field, R. Queguen Les representations de la sante, Health representations. pag 71 -84. villejuife: INSEPM 
Joosten, J. de Bruyn Ouboter-Kooli,E. Drop, M.J. Philipsen,H. 1990 'Bronnen van subjectieve belasting van moeders in gezinnen met een gehandicapl kind: de aandoening of het gezin? Mens en Maatschappij 65:245-270;

Kaplan, G.A., T. Camacho (1983) 'Perceived Health and Mortality: a nine year follow-up of the human population laboratory cohort.' American Journal of epidemiology 3: 292-304.

Kaplan. G.A., P.L. Kotler (1985) 'Sell reports predictive of mortality from ISH: a 9 year follow-up of the human population laboratory cohort' Joumal of chronic diseases 38: 14-40.

Kaplan, G. W. Barrel, A. Lusky (1988) 'Subjective state of health and survival in elderly adults.' Joumal of Gerontology 43: $\$ 114-120$.

Kaplan, G.E., J.T. Salonen, R.D.Cohen, R.J.Brand, S.L. Syme, Puska (1988) 'Social connections and mortality from all causes and from cardiovascular disease: prospective evidence from eastern Finland. American Journall of Epidemiology. 128:370-380.

Kim, J., C.W. Mueller (1978) 'Introduction to Factor Analysis: what it is and how to do it.' J.L. Sullivan (ed.) Quantitative Applications in the social sciences 13 Beverly Hills: Sage.

Kim, J., C.W. Mueller (1978) 'Factor Analysis: Statistical methods and practical issues. ' U.L. Sullivan (ed.) Quantitativa Applications in the social sciences 14 Beverly Hills: Sage.

King. D.S. J. Waldron (1989) 'Citizenship. Social Citizenship and the Defence of Welfare Provision' British Journal of Poltical Science: 18:415:443.

Klitzman. S. J.M. Stelliman (1989) 'The impact of the physical environment on the psychological wellw being of offlce workers.' Soc.Sci.Med. 29:733-742.

Knibbe, R.A. (1982) Probleemdrinken in Limburg Maastricht: Academisch Proefschrift Rijksuniversiteit Limburg.

Kobasa S.C. S.R. Maddi "Courington (1981) 'Personality and Constitution as Mediators in the StressIllness Relationship." Journal of Health and Behavior. 22:368-378.

Kraaykamp, G., L.B. Snippenburg. E.C. Ultee (1989) 'Beroepskllasse en beroepsprestige als verklaring voor inkomen, ongelijkheidsopvattingen, politiek vertrouwen en politieke apathie." Mens en Maatschappij. 64:42-61.

Konig-Zahn, C., Tax,B., Nuy, M.H.P., Hodiamont, P.D.G., Heydendael, P.H.J.M. (1993) 'Gezondheid en bestaansonzekerheid in Nederland'. Sociaal-Economische Gezondheidsverschillen 13. Den Haag: WMC

Kozlowski, L.T., Ferrence, R.G. (1990) 'Statistical Control in research on alcohol and tabacco: an example from research on alcohol and mortality". British Journal of Addiction 85: 271-278.

Krzyzanowski, M. M. Wysocki, (1986) 'The relation of 13-year mortality to ventilatory impairment and other respiratory symptoms: the Cracow study.' Int. Journal of Epidemiology 15:56-64.

Kuh, D.d.L., Wadsworth, M.E.J. (1993) 'Physical Health Status at 36 years in a British National Cohort" Social Science \& Medicine 37: 905-916.

Kunst AE $_{i}$ Mackenbach JP. (1990) Ischemische hartziekte: van managers- tot volksziekte. Een overzicht van de bewindingen uil de internationale literatuur. In: J.P. Mackenbach (red.) Sociaat-economische gezondheidsverschillon onderzocht. Deel I/. Den Haag. Ministerie WvC

Kunst, A.E. J.P. Mackenbach (1992) An International Comparison of Socio-Economic Inequalities in Mortality Rotterdam: Erasmus Universiteit.

Kunst AE, Mackenbach JP. (1993) The size of mortality differences associated with educational level: a comparison of 9 industrialized countries. "In Mackenbach J.P. (red.) Sociaal-economische gezondheidswersctillen onderzocht, deel VRijswijk: Ministerie WVC.

Lahelma, E. Volkonen, T. (1990) "Health and social inequalities in Finiand and elsewhere' Social Science and Medicine 31: 257-265.

Lamb, K.L., S. Dench, D.A. Brodie and K. Robents (1988) 'Sports participation and health status: a preliminary analysis.' Soc.Sci.Med. 27:1309-1316.

Lengius, A., Bjorvell, $H$., Antonowsky,A. (1992) 'The sense of coherence concept and its relation to personality traits in Swedish samples'. Scand. J. Caring Sci. 6:165-171

Langius,A., Biorvall "H. (1993) "Coping capability and functional status in a Swedish population sample". Scand. J. Caring Sci. 7:3-10

Leavey, R. D. Wilkin (1988) "A comparison of two survey measures of health status." Soc.Sci.Med. 27:269-275.

Lecierc, A., F. Lert, C. Fabien (1990) 'Differential mortality: some comparisons between England and Wales, Finland and France, based on inequality measures.' International Journal of Epidemiology 19:53-60. 
Lemmens, P.H.H.M. (1990) Measurement and distribution of alcohol consumption Matastrich: Acade misch Proefschrift Rijksuniversiteit Limburg.

Leeflang. R.L.I. I. P. Spruit (1991) "Gezondheidszorg onder buitentandars." In: C.W. Aakster, G.Kuiper". J.W. Groothoff (red.) Medische Sociologie Groningen: Wolters-Noordholf

Lepore, S.J., G.W. Evans, M.N. Palsane (1991) 'Social Hassies and psychological health in the oontext of chronic crowding." Journal of Health and Social Behaviout $32: 357-367$.

Lewin, J.S. H.Y. Vanderpool (1987) 'Is trequent religlous attendance really conductive to better heath? toward an epidemiology of refilgion.' Social Science and Medicine 24589-600.

Lichtenstein. P., Harris, J.R., Pedersen, N.L. McClearn, G.E. (1992) "Socioeconomic Status and Physical Health, How are they related? An empirical Study on twins reared apant and twins reared together' Social Science \& Medicine 36: $441-450$.

Link, B.G., F.P. Mesagno, M.E. Lubner, B.P. Dohrenwend (1990) "Problems in Measuring Role Strains and Socilal Functioning in relation to psychological symptoms.' Jounal of Health and Social Bohawor. $31: 354-369$

Litwak, E. P. Messeri (1989) "Organizational theory, social supports, and mortally rates: A theoretical convergence." American Sociological Review. 54:49-66.

Luctht. F. van der (1992) Sociale ongelikheid en gezondheid bij kinderen. Groningen: dissertatie RuG.

Luch, F. vall der (1993) "Causatie- on selectieprocessen onder kinderen als verklaring voor sociaaleconomische gezondheidswerschillen." Social-economische gezondheidsverschillen onderzocht 11 : $1-20$.

Luhmann, N. (Hrsg.)(1985a) Soziale Differenzierung Opladen: Westdeutscher Varlag

Luhmann, N. (1985b) "Zum Begriff der sozlalen Klasse." In: N. Luhmann (Hrsg.) Soziale Differenzionung pag.:119-162. Opladen: Westdeuischer Verlag.

Lundberg. 0 . (1991) 'Causal explanations for class inequality in health -an empirical analysis'. Social Science \& Medicine 32: 385-93

Lundman, B., Norberg, ATl. (1993) 'The significance of a sense of coherence fior subjective health in persons with insulin-dependent diebetes." J. Adv. Nurs. 18:381-6.

Lydeard. L. R. Jones (1989) 'Llife Events, Vumerability and Iliness: A selected Roview.' Family Practice. $6: 307-315$.

Maas van der, P.J. J.D.F. Habbema, G.A.M. van den Bos e.a. (1987) Vergelikend buurtonderzoek Amsieralam U. Amsterdam:"Institul Sociale Geneskunde Lniversiteit van Amsterdam.

Macintyre, S. (1986) 'The patterning of health by social position in contemporary Britain: directions for sociological research." Social Science \& Medicine 23,393-415

Macintyre, S. (1988) "A review of the social patterning and significance of measures of height, welght. blood pressure and respiratory function:" Soc.Sci.Med. 27:327-337.

Mackenbiach, ل. P. K. Stronks (1988) Recent Nederlands onderzoek op het gebled van sociaal-economische gezondheidsverschillen. Rotlerdam:Instituut Maatschappellike Gezondheidszorg, Erasmus Universiteit.

Mackenbach, J.P. (1994) Ongazonde verschillen. over sociale straticatie an gezondheid in Naderland. Assen: van Gorcum.

Marmot. M.G. (1986) "Social inequalities in mortatity" the social environment." In P.G. Wikinson Class and Health: research amd longitudinal data. London: Tawistock.

Marshall, T.H. (1977) Class, Chtizenship and Social Dewelopment. Chicago: University of Chicago Prass Martin. P., (1987) The concept of class. In: R.J. Anderson. W.A. Hughes. W.W. Sharrock Classic disoutes in sociology pp 67-96. London: Allensunwin.

McLeod, J.D., A.C. Kessier (1990) 'Socioeconomic Status Differences in Vulnerability to Undesirable life events, Journal of Health and Social Behavior. 31:162-172

Mechanic. D. (1982) Symptoms, Uness Behavior and Holp seeking New York Prodist

Merton. R.K. (1968) Social Theory and Social Stucture, 1968 enlarged edition. New York: the Froe Press Meerling (1981) Methoden en tuchnieken van psychologisch onderzoek dl 2 Meppel: Boom.

Merens-Riedstra. H. (1981) Leven zonder werk een sociaal-wetenschappeilik onderzoek near arbeidsongeschiktheio Maastricht: Academisch Proefschrift, Piiksuniwersiteit Limburg.

Meiman F.j. (1990) 'De klachtgerichte benadering bedreigd ?' Hulsarts en Woldonschap. 33:478-481.

Moen, P., D.Dempster-MlcClain en R.M. Williams (1989) "Social Integration and Longevity: An event history analysis of women's roles and resilience." American Sociological Peview. 54:635-647.

Mootz. M. (1986) 'Health indicators.' Soc. Sci.Med. 22.255-263. 
Mootz, M. J. van den Berg (1989) 'Gezondheidsenquetes en Indicatoren woor gezondheidstoestand in de CBS-Gezondheldsenquete. "Maandber. gezondheid (CBS). 2:5-10.

Mootz, M., M. Konings-van der Snoek (1987) 'Gezonden en zieken vergeleken. Gezondheld \& Samenleving a:241-250

Morgan, M. W. Calnan, N. Manning (1985) Sociological approachos to heath and medicine. London/Sydney: Croom Helm.

Mossey, J.M., E. Shapiro (1982) 'Self-rated health: a predictor of mortality among the elderly.' American Journal of public health 72:800-808.

Navarro, V. (1976) Crisis, health, and medicine. New York/London:Tavistock Publications.

Nifhof, G. (1991) 'Verklaringen van chroniciteit in levenswerhalen. 'In: G.W. Aakster, G. Kuiper, J.W.Groothoff (red) Medische Sociologie. pag.:104-112. Groningen:Woiters-Noordhoff, geheel herziene $4^{\text {bi }}$ druk.

Oaklsy, A. Rajan, L. (1993) What did your baby eat yesterday? Social Factors and infant foeding practices'. Eurcpean Joumal of Public Health 3: 18-27

Oakley. A., Gigby, A.S., Hickey. D. (1993) Woman and children last? Class, health and the role of maternal and child health services'. European Journal of Public Health 3: $220-226$

Oakley, A., Rigby, AS. Hickey, D. (1994) 'Life stress, support and class inequality; Explainig the health of women and children". European Joumall of Public Health 4:81-91.

Porter, H.H. Hook, E.B. (1980) Human Embryonic and Fetal Death New York: Academic Press.

Omran, A.R. (1979) 'Changing patterns of health and disease during the process of national development:' In: G.L. Albrecht, P.C. Higgins (eds) Health, ithess and medicine. pag.:81=93. Chicago: Rand McNally.

Querido, J.D. (1981) 'Morbiditeit en problematiek van alleenstaanden.' Huisarts en wetenschap. 34:173182.

Rahkonen, O. Laheima, E., Huuhka, M. (1994) "Past or present? Childhood living conditions and current social class as determinants of aduit health" paper ESMS-conference, Vienna 1994.

Rall, R., Rimmerman, A. (1993) "Parental attitudes to out-ol-home placement of young children with developmental disabilities." Int. J. Rehabil. Res. 16: 97-105.

Reek. J. van (1983) 'Roakgedrag in Nederland van 1958-1982.' 1.alc.drugs. 9:99-103.

Reek, J. van, R.A. Knibbe. M.J. Drop (1983) 'Ontwikkelingen in alkoholgebruik in Nederland tussen 1958 en 1981. Tijdschrift voor Sociale Gezondheidszorg. 61:954-959.

Reek, J. van, M.J. Drop and J. Joosten (1985) 'Het rookgedrag van Nederlandse schoolkinderen en de inwloed van leeftijdgenoten en ouders.'. Tijdschrift voor alcohol, drugs en andere psychotrope stoffen 11:

Rimlinger, Gi. V. (1966) 'Welfare policy and economic development: A comparative historical perspective.' Journal of Economic History. 26:556-571.

Rosen, G. (1973) 'Disease, debility and death.' In: H.d. Dyos, M. Wolff (eds) The Victorian City, Images and Realities. Vol 2:625-669. London/Eoston.

Pijckevorsel, J.L.A. van, J. de Leeuw (1988) Component and Correspondence Analysis: dimension reduction by functional approximation Chichester: Jahn Wiley.

Schaper, .G. (1990) 'Alcoliol and Mortality" a rewtew of prospective studies.' Br. J. Addiction 85: $837-847$.

Scherbourne, C.D., R.D. Hays (1990) 'Marital status, social support, and health transitions in chronic disease palients.' Journai of Health and Social Behavior. 31:328-343.

Schiller, P.L. J.S. Levin (1988) 'Is there a religious factor in health care utilization?: a review." Soc Sci.Med. 27:1369.1379.

Schnabel, P. (1991) 'De verbreding van de gezinsgeneeskunde to de alleenstaanden. 'Huisarts en Wotenschap. 34:156-157.

Schouten, M. (1976) De socialen zilin in aantocht. De Noderlandse arbeidersbeweging in de negentiende ouw. Amsterdam:Van Gennep.

Schroer CAP, Bullinga RS (1990) Gezondheidsverschillen tussen sociaal-economische statusgroepen: effect van verschillen in leefwilze of arbeidsbelasting? Maastricht: vakgroep Medische Sociologie. RL

Schroer, C.A.P., R.S. Bullinga (1990) 'Gezondheidsverschillen tussen Soclaal-economische statusgroepen.' Bedrijtsgezondheidszorgstudies. 6 Maastricht: $1-41$.

Schuyt, C.J.M. (1991) Op zook naar het hart van de verzorgingsstaat. Leiden: Stenfert Kroese.

SCP (1990) Socialal en Cultureal Rapport. Den Haag:VUGA.

SCP (1991) Sociale allas van de vrouw Den Haag: VUGA.

Seeman "T.E., G.A. Kaplan, L. Knudsen, R. Cohen, J. Guralnik (1987) 'Social newwork ties and mortality among the elderiy in the Alameda county study.: American Journal of Epidemiology. 126: 
Sen, A. (1993) 'The Economics of Life and Death.' Scientific American 268: 18-25.

Sherboume, CD. R.D. Hays (1990) Marital status, sochal suppont and healh transitions in chronito disease patients." Joumal of health and social behavio $31,328-343$.

Shotter, J. (1993) 'Psychology and Citzenship: Identity and Belonging.' in: B. S. Turner(ed, ) Citizenship and social Theory. London: Sage

Siegel, S. (1956) Nonparametric statistics for the behavioral sciences. New York: McGraw-4lil

Stegrist, I., R. Peter, A.Junge. P.Cremer and D. Seidel (1991) Low status control, high eftort at work and ischemic heart disease: prospective evidence from blue-collar men." Soctal Science and Medicine. $31: 1127-1134$.

Sikkel, D. (1984) 'Leefsituatieonderzoek vergelikenderwijs: de VOEG.' Sociaal Gultureel Kwartaaberioht $6: 9-11$.

Singer, E., R. Gartinkel, M. Conen, L. Stole (1976) Mortality and menta: Mealth: Evidence from the motown Manhattan restudy." Social Science and Medicine 10:517-525.

Soderfeldt B. B. Danermark, S. Larsson (1989) 'Class Inequality in Heaith' Journal Soc. Med. 17:207. 215.

Sonsbeek, J.LA. van (1989) 'Gezondhheidsenquetes en (On)gezonde steden.' Mndber gezondheid (CBS). $8: 5-17$.

Sonsbeek, J.LA. van, (1990) De Voeg: klaaglijst of lijst met gezondheidsklachten." Statistische Onderzoekingen M37Den Haag: SDU.

Sprengers, M. F. Tazelaar (1987) "Werkloosheid en sociaal netwerk.' In: I.P. Spruit, F. Tazelaar (red.) Leven met werkloosheid pp.: $187-497$. Groningen: Wolters-Noordholl.

Spruit, L.P. (1988) De betekenis van sociale stratificatie voor gezondheid.' T. Soc. Gezondheidsz. $66: 339-343$

Spruit. I.P. (1990) "Health and social inequitles in the Netherlands: Soc.ScilMed 31:319-329.

Stering. T.D. (1978) "Does smoking kill workers or working kill smokers?". "International woumal of Health Services. 8:437-452.

Stronks, K., J.P. Mackenbach (1988) 'Recent Nederlands onderzoek op het gebied van sociaal-economische gezondheidsverschillen.' Tijdschrift voor Sociale Gezondheidszorg. 66:349-354.

Swaan, A. de (1988) in Care of the State: health care, education and welfare in Europe and the USA in the Modern Efa. Cambridge: Polity Press.

Swinkels, H. (1989) "Gezondheidsenquetes en Trendcilfers gezondheidsenquete 1981-1988," Maandber gezondheid (CBS) . 9:5-24.

Tabachnik, B.G., L.S. Fidell (1989) Using mustivariate statistics $2^{\text {nd }}$ ed. New York: Harper \& Row.

Tellis-Nayak, V. (1982) "The transcendent standard: the religious ethos of the rural elderly.' Gerontologist. 22:359-363.

Tessler R.C., D. Mechanic (1978) 'Psychological distress and Perceived Health Status.' Journal Health \& Social Behavior. 19:254-262.

Thoits, P. (1986) Multiple Identities: examining gender and marital status differences in distress. Journal of Health and Social Behavior 51:259-272.

Thoits, P. (1987) "Gender and Marital Status Differences in Contral and Distress: common stress versus unique stress explanations.' Journal of Health and social behavior $28,7-22$

Thoma. P. (1979) 'Arbeit und Krankheit.' In. B. Geissler, P. Thoma (Hg.) Medizinsoziologio, 20 rev. und erw. Aufl pag. 93-115. Frankfurt New Vork:Campus Veriag.

Townsend. P. N. Davidson (eds) (1982) Inequalities in health. Tho Black Roport. London: Pellican/ Penguin Books.

Tuchman, B.W. (1979) A disiant mirror. The calamitous $14^{\text {th }}$ century. London:Penguin Books/Macmillan.

Tumer, B.S. (1987) Medical power and social knowiedge. London Sage Publications.

Tumer, B.S. (1988) Status Millon Keynes: Open University Press.

Turner, B.S. (1990) 'Outline of a theory of citizenship' Sociollogy 24:189-217.

Tumer, B.S. (1992) Regulating Bodies: Essays in medical sociology. London: Roulledge.

Turner. B.S. (1993) 'Contemporary Problems in the theory of citizenship'. in B.S. Tumer (ed.) Citizenship and Social Theory. London: Sage.

Turnet R.J., S. Noh (1988) 'Physical Disability and Depression: A Longitudinal Analysis.' Joumal of Health and Social Behavior. 29:23-37

Tumer, R.J., C.F. Grindstaff. N. Phillips (1990) 'Social suppon and outcome in teenage pregrancy." Journal of Health and Social Behavior. 31:43-57.

Ubachs, M. (1976) Een eouw modern kapitalisme. De Regouts/Leed en strijd wan Maastrichts proletari. aat. Nijmegen:LINK (Heruitgawe van het in 1934 onder dezellde titel gepublicearde werk) 
Uitee, W. N.D de Graaf. F. van Puijenbroek (1988) Gezonde en ongezonde vraagstellingen TSG 66:333-339.

van Weegel, J. Heydendael. P.H.J.M. (1993) Dakloosheid en Psychische stoonissen, Utrecht: NCGV.

Verbrugge, L.M.(1985) 'Gender and Health: an-update of hypothesis and evidence.' Journal of Health and Social Behavior 26:156-182.

Verbrugge L.M. (1989) 'The twain Meel: Empirical explanations of sex differences in health and mortality. Journal of health and social behavior. 30:282-304.

Verdoom, J.A. (1981) Het gezondheidswezen to Amsterdam in de 19e eeuw. Nimegen:SUN (Heruitgave wan Volksgezondheid en sociale ontwikkeling. Spectrum, Utrecht/Antwerpen, 1965).

Verhoogt, J.P. (1983) 'Sociale strathicate als sociaal probleem. "In D.Th. Kuipers, J. Naafs (red.) Stratificatie anno 1983: Over recente ontwikkelingen inzake theorie, onderzoek en beleid Amsterdam: WU.

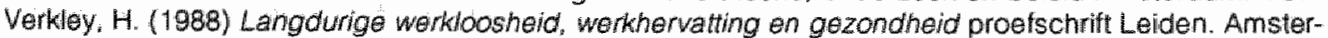
dam: Swetz:Zeitlinger.

Vernon. S.W., P.A. Buffler (1988) 'The status of status inconsistency.' Epidemiologic Reviews. 10:65-86.

Visser. A.PH. (1983) 'De betekenis van de VOEG: enkele gegevens over begripswaliditeit.' Gezondheid wn Samenleving 3:177-188.

Wegistaff, A. P. Paci, E. van Doorslaer (1991) 'On the measurement of inequalities in health." Soc Sci.\&. Med. 33: 545-557.

Wadsworth, M.E.J. (1986) 'Serious illness childhood and its association with later-life achievement'. in: Wikinson, R.G. (ed.) (1986) Class and Health London: Tavistock.

West, P. (1988) 'Inequalities? Social Class differentials in health in British youth.' Soc. Sci.Med. 27:291$-296$.

Wethington, E. R.C. Kessler (1986) "Perceived support, received support, and adjustment to stressfull life events." Journal of Health and Social Behavior. 27:78-89.

Whitehead, M. (1987) The Health Devide Harmondsworth: Penguin Books

Williams D.R. (1990) "Socioeconomic differentials in health: A review and redirection." Social Psychology Quarterly. 53:81-99.

Williams, F. (1983) 'Concepts of Health: an analysis of lay logic.' Sociology 17: 183-205.

Wilkinson, R.G. (ed.) (1986) Class and Health London: Tavistock.

Wilkinson. P.G. (1990) "Income distribution and mortality: a "natural" experiment." Sociology of Health \& Illiness $12391-412$.

Whulk-Lipinski, E. (1990) 'The Polish country profile: ecomomic crisis and inequalities in health.' Soc. Sci. Med. 31:859-866.

Winuk-Lipinski ${ }_{\text {E. }}$, and R. Allsley (1990) 'International comparative analysis: main findings and conclusions." Soc. Sci.Med. 31:879-889.

Zee, J. van der (1982) De vraag naar de diensten van de huisarts Maastricht: dissertatie RL.

Zola, K.I. (1973) De medische macht. Meppel:Boom. 


\section{BIJLAGE}

Schema A Rubrieken van gebruikte variabelen en hun voorkomen in de onderschelden steeproeven van de Nederlandse Bevolking

\begin{tabular}{|c|c|c|c|c|c|c|c|c|}
\hline \multirow[b]{2}{*}{ 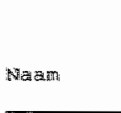 } & \multicolumn{5}{|l|}{ Sirvey } & \multicolumn{2}{|l|}{ Pentel. } & \multirow[b]{2}{*}{ Inthond } \\
\hline & 1978 & 1977 & $\begin{array}{l}1980 \\
\text { COS }\end{array}$ & $\begin{array}{l}2980 \\
50 P\end{array}$ & 1983 & $190 \mathrm{e}$ & 1983 & \\
\hline \multicolumn{9}{|c|}{ Gerandheid } \\
\hline $\mathrm{CHE}, \mathrm{ZIEK}$ & CHSR & CHF_ZLEF & $\mathrm{CH} \mathrm{CH}_{\mathrm{m}} \mathrm{2} \mathrm{I} \mathrm{SR}$ & CHF_CIER & CHA_ZEK & CHRERE & GHR $2-1 E$ & 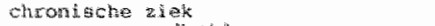 \\
\hline OEQ & $O E G$ & $\mathrm{OES}^{-}$ & 086 & OEG & OEO & ORE & OEQ & ervaren gezondila 1 a \\
\hline WOEG_13 & WOEG 13 & VOEG_13 & Vote 13 & YOEE_L & VOES & VOEG_12 & WEO_ 13 & ervaten \\
\hline \multicolumn{9}{|c|}{ Achnergzordikanmer kan } \\
\hline OP_LFD & $O \mathrm{P}_{-} \mathrm{EPTS}$ & QP LETE & OP_LPrD & DP_LETE & 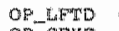 & OP. & 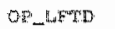 & $10,5 \mathrm{~F}$ \\
\hline OP $-5 \mathrm{SEX}$ & DE_SERE & $O Y_{\perp} S E K E$ & OP_SEX: & $O P_{-}$SEXE & $O P_{\text {m SENE }}$ & OP'_SEXE & $O P-S E N$ & ges lacht \\
\hline \multicolumn{9}{|c|}{ Socialie Differemtiati } \\
\hline OADARTO & GNDNIWO & ONDENTWO & ONDENI VO & OMDENVO & ONDNIWO & 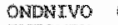 & ONDHEVO & 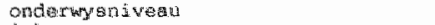 \\
\hline THWOMEH & I NKOWEN & INKOMEN & TW[KOMEN & WWOKAEN & FNKOWEW & INAROASE & XNKOMEN & inkonitera \\
\hline SG_LEF & SC_DEF & $\mathrm{SC}_{1-2} \mathrm{DE}$ & SG_DEF & SOLEP & $S G \_D E F$ & $8 Q_{\triangle} D E F$ & SQ_DE & soctide groep \\
\hline $\begin{array}{l}\text { Letstijt } \\
\text { Metactian }\end{array}$ & peltjke or & cientat & & & & & & \\
\hline PEER & $\begin{array}{l}\text { Pelijke or } \\
\text { KERK }\end{array}$ & $\begin{array}{l}\text { Cisentat } \\
\text { KERK }\end{array}$ & & & & & & \\
\hline POEITTER & POLTHYTER & POLTHTEK & $\begin{array}{l}\text { RERK } \\
\text { POLELETEK }\end{array}$ & NEEK & $\begin{array}{l}\text { RERK } \\
\text { EOHITIEK }\end{array}$ & 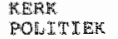 & 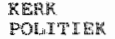 & 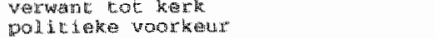 \\
\hline \multicolumn{9}{|c|}{ vxije fijd besteding } \\
\hline VT: 1 & WT. & vrs & & VTS & Wris & & & 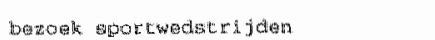 \\
\hline WT2 & vint & $\sqrt{m 2}$ & & $\sqrt{752}$ & WT2 & & & 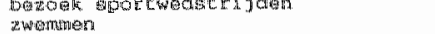 \\
\hline mis & VI: & & & $\mathrm{NT}$ & wr & & & $\begin{array}{l}\text { zumentar } \\
\text { andere watersport }\end{array}$ \\
\hline VT: & $\sqrt{2}$ & $W^{2}$ & & VT4 & wh & & & ghore 1 ith. sport \\
\hline $\mathrm{VT}_{\mathrm{T}} \mathrm{A}$ & & What & & & & & & 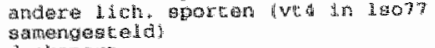 \\
\hline What & $\operatorname{Vxt} 5$ & WS & & $\operatorname{Vrs} 5$ & WTS & & & denkepor \\
\hline Whe & WT 6 & wh & & VTt & WTE & & & 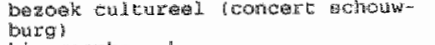 \\
\hline 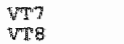 & vin & VT? & & W & VT7 & & & bioscoopbiezork \\
\hline the & WTE & WTB & & val & WTS & & & 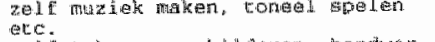 \\
\hline$\sqrt{1} 9$ & $\sqrt{25}$ & VPS & & $\operatorname{veg}$ & VT⿱ & & & 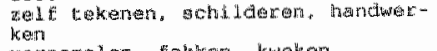 \\
\hline VTa & Fria & & & $\begin{array}{l}\mathrm{VT}^{2} 10 \\
\mathrm{VW}^{\mathrm{T}} \mathrm{N} 1 \mathrm{H}\end{array}$ & visa & & & wertarkelen, rokken, kweker \\
\hline $\ln ^{2}-1$ & $\begin{array}{l}\operatorname{Var} 11 \\
\operatorname{vit} 12\end{array}$ & $\begin{array}{l}\text { VT11 } \\
\text { VT12 }\end{array}$ & & $\begin{array}{l}\text { WN1 } \\
\text { WTI }\end{array}$ & Wh & & & apel let jeg \\
\hline & mis & & & & $\mathrm{mr} 12$ & & & 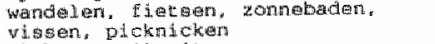 \\
\hline WTI 3 & $\begin{array}{l}\text { VII } \\
\text { VII }\end{array}$ & v:14 & & 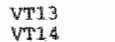 & WP13 & & & clubed, gorjeceiten \\
\hline$\sqrt{2} 15$ & VTI 15 & $\begin{array}{l}\operatorname{Mr} 34 \\
\operatorname{VT} 15\end{array}$ & & $\begin{array}{l}\text { Vrat } \\
\text { vin' } 15\end{array}$ & Wrid & & & dancing, disco \\
\hline Wa 6 & VTT 6 & VE16 & & $\begin{array}{l}\text { VT15 } \\
\text { VTHE }\end{array}$ & $\begin{array}{l}\text { WT15 } \\
\text { WT1 } 16\end{array}$ & & & Iadio luisterer \\
\hline Weating & VWT 17 & $v+17$ & & $\begin{array}{ll}\text { PTHE } \\
\operatorname{Vin} 27\end{array}$ & vit? & & & 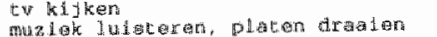 \\
\hline $\operatorname{mog}$ & VT:18: & VI1 & & W & พั1 18 & & & 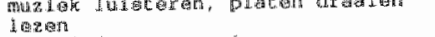 \\
\hline $\begin{array}{l}24 \\
2125\end{array}$ & & $\mathrm{VT} 24$ & & & जT:2 & & & kotern \\
\hline 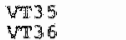 & $\operatorname{Ves} 3$ & Vit 35 & & $\operatorname{vin} 35$ & VT 15 & & & 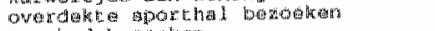 \\
\hline WT. & VT36 & $\sqrt{12} 36$ & & WT: 36 & MT36 & & & 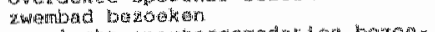 \\
\hline $\mathrm{WT} 3 \mathrm{~T}$ & $\operatorname{vr} 3 y$ & vis 37 & & $w^{3}$ & wit 37 & & & 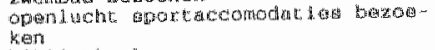 \\
\hline 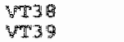 & $\sin 39$ & $\operatorname{var} 38$ & & $4 T 31$ & $\operatorname{van} 3$ & & & 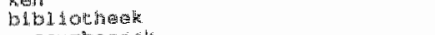 \\
\hline 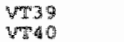 & virs & $\operatorname{van} 399$ & & whes & VEs 39 & & & mu Beumbiat $200 \mathrm{~K}$ \\
\hline 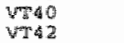 & vT: & Vhe 40 & & WT: 40 & veto & & & 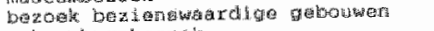 \\
\hline $\begin{array}{l}\mathrm{VT} 4 \mathrm{Z} \\
\mathrm{VT} / 3\end{array}$ & veraz & $\operatorname{VTH} 2$ & & & & & & 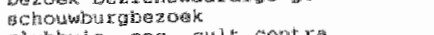 \\
\hline $\begin{array}{ll}\mathrm{VI} \\
\mathrm{W}\end{array}$ & 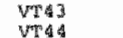 & VI: 43 & & WT4 3 & $\operatorname{Ves} 43$ & & & 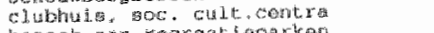 \\
\hline $\begin{array}{l}\sqrt{3} \\
\sqrt{2} \cdot 4\end{array}$ & $\operatorname{vin} 45$ & $\sqrt{14} 4$ & & Wot:4 & m4 & & & 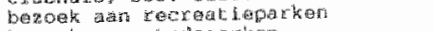 \\
\hline 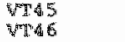 & VI 45 & VTS 5 & & 4705 & $\ln 45$ & & & 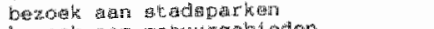 \\
\hline 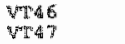 & 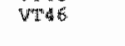 & VT) 6 & & $\operatorname{Vin} 46$ & VTe 6 & & & 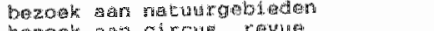 \\
\hline 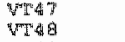 & & VT 47 & & ท. 47 & 1277 & & & 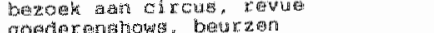 \\
\hline $\begin{array}{l}\sqrt{2} 48 \\
\sqrt{4}+49\end{array}$ & & VT: 8 & & $V D Q$ & $\sqrt{2}+4$ & & & 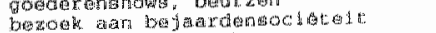 \\
\hline$\sqrt{15} 5$ & & $\mathrm{VT}^{4} \mathrm{~s}$ & & $\operatorname{lng} 49$ & 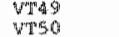 & & & \\
\hline VT5 51 & & Wh: & & $\begin{array}{l}\text { WTS } \\
\operatorname{wan} 51\end{array}$ & vat 1 & & & nelnkelers \\
\hline & & & & & $\sqrt{1} 52$ & & & gerand \\
\hline
\end{tabular}


Schema A Rubrieken van gebruikte vartabelen en hun vookkomen in de onderscheiden steekproeven van de Nederlandse Bevolking (vervolg)

\begin{tabular}{|c|c|c|c|c|c|c|c|c|}
\hline \multirow[b]{2}{*}{ Wastisto } & \multicolumn{5}{|l|}{ Eurwey } & \multicolumn{2}{|l|}{ Parel } & \multirow[b]{2}{*}{ If shoud } \\
\hline & 293 & 1597 & $\begin{array}{l}1969 \\
0196\end{array}$ & $\begin{array}{l}1,900 \\
\text { Sc: }\end{array}$ & 1983 & 109 & 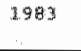 & \\
\hline \multicolumn{9}{|c|}{ MlB kinte Genomite } \\
\hline $\begin{array}{l}\text { ALE } \\
\text { SLLE }\end{array}$ & & & Allici & ALCL & $\begin{array}{l}\text { ALCI } \\
\text { ALE2 }\end{array}$ & $\begin{array}{l}\text { ALC1 } \\
\text { RLEZ }\end{array}$ & $\begin{array}{ll}A C E C L \\
A L C 2\end{array}$ & 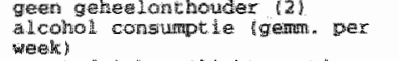 \\
\hline HIS & & & Aldit: & Nos & ALE 3 & $A L C 3$ & ALCW & 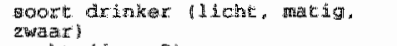 \\
\hline cosk & & & HoOH $\mathrm{I}$ & AONOK2 & ROOKL & $\operatorname{maOKI}$ & ROONI & rooke $(j a-2)$ \\
\hline poover & & & POOKK 2 & DON & $\operatorname{ROON2}$ & ROOKR & 5002 & gemm. arantal a ligargten \\
\hline coors & & & nOONO & PODKA & & ROOK3 & RoON 3 & gemb. antal shagrgies \\
\hline Fooken & & & EDoos & Beoret & FOCNA & ROONA & ROOKA & germ. a antil. pujpen \\
\hline $000 \%$ & & & ROOOKE & Rooks & ROOKS & FoO 5 & Fooks & gemat, aamal slegar \\
\hline \multirow{2}{*}{\multicolumn{9}{|c|}{ 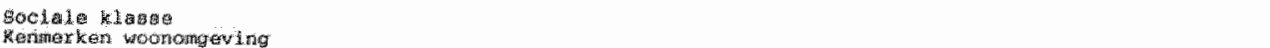 }} \\
\hline 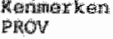 & & & & & & & & \\
\hline $\begin{array}{l}\text { Prov" } \\
\text { uris }\end{array}$ & $\mathrm{PHON}$ & Plogir & How & PHOV & PHOV & PROV & PROY & Detow incie \\
\hline ORACE: & 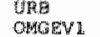 & WHas & Ufiptis & URe & Uake & URB & UR & 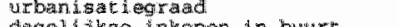 \\
\hline OHOHU & OGG & & $\begin{array}{l}\text { OHGEW } \\
\text { OACREZ2 }\end{array}$ & & 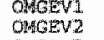 & & & 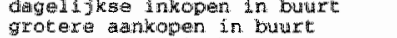 \\
\hline CMOEU & OHW & & 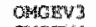 & & OSTEVI & & & 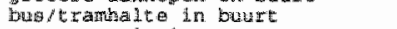 \\
\hline OMeten & OHAOH & HOEYH & OHOHW & & OWGEVA & & & gromvoorzi errich \\
\hline Ohoteris:5 & & & Oefordy & & 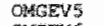 & & & posthatritoor \\
\hline OAdows & OHCOAS & & OMCONWE & & OntG: 146 & & & bats is achool. \\
\hline MES V? & & & 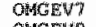 & & OASCEV & & & het farts \\
\hline $\begin{array}{l}\text { OAOEHB } \\
\text { CMEEMO }\end{array}$ & MHEVG & $O H C M D$ & OAGF" & & OAdGEV & & & $\begin{array}{l}\text { cafe, dorpshus } \\
\text { areche }\end{array}$ \\
\hline \multicolumn{9}{|c|}{ Inu i wragtcing } \\
\hline Goond & & & MON1 & & & & & noofobentoner \\
\hline WOON2 & 40042 & 1400012 & & WOOn 2 & WOOE 2 & WOOAN2 & & mondngtype \\
\hline worist & 40013 & & & Woows & WOONN3 & & & complax \\
\hline $\begin{array}{l}\text { WOOMU } \\
\text { WOOR:5 }\end{array}$ & $\begin{array}{l}\text { MOOn! } \\
\text { WOONS }\end{array}$ & 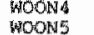 & $1900 \times 14$ & 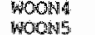 & 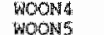 & & & $\begin{array}{l}\text { boutjiatar } \\
\text { mant o } 1 \text { kamers }\end{array}$ \\
\hline wonots & WOON16 & WOONA & WOON⿴囗十⺝ & WOON W & $\begin{array}{l}\text { WOON5 } \\
\text { WOOWE }\end{array}$ & & & 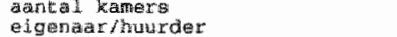 \\
\hline WCON? & & Woon? & WoON? & Woop? & & & & verkoopwatarde \\
\hline Woond & & & Woond & & HOONE & & & hoogte hunf \\
\hline 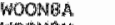 & & & WOOHA & & WOCONBA & & & rente +at lossing hypotheek \\
\hline Wow & WoOnNäI & HCONRH & WOONHA & WOONB & WOC6:A & & & hoogte hunr \\
\hline HODNA & 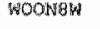 & & & & & & & huurwarade wonsha \\
\hline 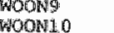 & & WOON9 & WDONLO & & & & & garage \\
\hline 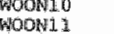 & WOONH & $\begin{array}{l}\text { WOOWI. } \\
100 \mathrm{H} 11\end{array}$ & $\begin{array}{l}\text { WDONAL } \\
\text { WOOH } 11\end{array}$ & $\begin{array}{l}\text { WON } 10 \\
\text { WOONI }\end{array}$ & & & & whin/volkstuin \\
\hline & $\begin{array}{l}\text { WOONH } \\
\text { WOONL }\end{array}$ & $\begin{array}{l}\text { WOOH } 12 \\
\text { woow2 } 2\end{array}$ & woond.2 & & & & & $\begin{array}{l}\text { c.V. } \\
\text { doucher, bad }\end{array}$ \\
\hline GOONL 3 & WOON 11 . 3 & & & WOONI 3 & WOOW13. & & & $\begin{array}{l}\text { douthe, bad } \\
\text { gelud dshindex }\end{array}$ \\
\hline WOOWLA & HOOM:1 & WOONH 4 & WOOH: 4 & WOON14 & & & & - vark kinderem \\
\hline WoONH 5 & MOCHNH & WOON1.5 & WOOHE 5 & HOON:15 & & & & - vary buren \\
\hline WONA & mond & WOOH16 & WWON 16 & WOON1 6 & & & & - yan weoverker \\
\hline SOON1. & HOON2? & WOOA 7 & WOOHW 7 & WOWHב & & & & var terein of merro \\
\hline WOON'1. & WoONA & & & WOON11 & & & & * var bussam, trams \\
\hline $600 \mathrm{N2}$ & คoONL: & NOONH & Woond & WODN29 & & & & - var vliegulugem \\
\hline WOON20 & HOON20 & & NoOK20 & WOOH20 & & & & * Van tinduster \\
\hline WOONA 2 & moOnd 1 & WOMna 1 & & HOONZ 1 & WOON2 2 & & & stankowerlage \\
\hline $400 \mathrm{N2}$ & & & & W0O422 & & & & - viar sloot, riviet \\
\hline FOONA 3 & & & $5000 \mathrm{~N} 23$ & & & & & - vari vertecer \\
\hline MOONZ & & & WOWOA & & & & & - varz indiatide \\
\hline WOON & 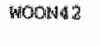 & Wounda.2 & & WOON 42 & 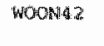 & & & 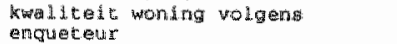 \\
\hline HOHOH & & & Wolow 5 & & HOOA 45 & & & tevrecten met whonruine \\
\hline HOONA6 & & & WOONdi 6 & & HOON & & & 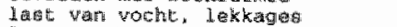 \\
\hline troOks dis & & & Woow 47 & & 600044.7 & & & Jafte valr kou, coche \\
\hline 0010449 & & & & & 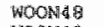 & & & vooroat logge butre \\
\hline WOON & 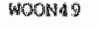 & HOOMU & & & Wook 49 & & & h.h. intonend \\
\hline WOONEOA & & & & & WOOH5 $10 \mathrm{~A}$ & & & huUE SubB date \\
\hline HOCNS & & & & & WOH & & & 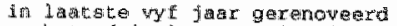 \\
\hline WOONG & & & & & WOON $5 \%$ & & & 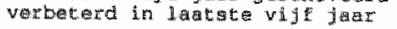 \\
\hline
\end{tabular}


Schema A Rubrieken van gebruikte variabelen an hun woorkomen in de onderschaiden steekproeven van de Nederlandse Bevolking (vervolg)

\begin{tabular}{|c|c|c|c|c|c|c|c|}
\hline \multirow[b]{2}{*}{ 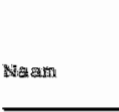 } & \multicolumn{5}{|l|}{ Survesy } & partes & \multirow[b]{2}{*}{ Inhotut } \\
\hline & 1974 & 1977 & $\begin{array}{l}1980 \\
\mathrm{c} 2 \mathrm{~s}\end{array}$ & $\begin{array}{l}1980 \\
\operatorname{scp}\end{array}$ & $19: 93$ & 1983 & \\
\hline \multicolumn{8}{|c|}{ peretctingen } \\
\hline 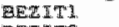 & BERYPI & BEZTTI & & $B E Z E T$ & & & 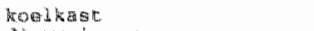 \\
\hline 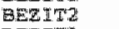 & EERITZ & BERT2 & & & BERCT2 & & 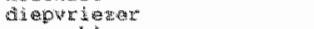 \\
\hline DEZITJ & DEET & BHERT & & gE2TI3 & & & wasinachine \\
\hline BEE ITु & BEEIS I & BEZITU & & BEZI & & & cient 1 Euge \\
\hline BERTIS & BERTTS & BERITS & EEZIPY & BE2 IT 5 & PQRITS & & mastroger \\
\hline PESTE & BEETTS & BE2 ET6 & BERIT6 & BE2 $2+6$ & BE: T: T: & & 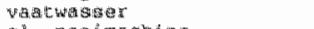 \\
\hline BEETET & BEZITT & $\operatorname{BEZ} 3 \mathrm{TP}$ & & BEZT? & 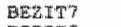 & & 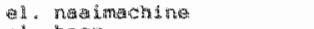 \\
\hline PERTE & & BEXITA & & BEZITB & BEYTT & & Q1. bont \\
\hline 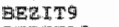 & BERITS & BE2IF9 & 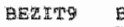 & SEZTT 9 & BEUYTS & & kd euren t. Y \\
\hline BEEITIO & EEEITIO & BK2IT10 & & BESATIO & BEZIW 0 & & Whast nNat: to. \\
\hline EEEITH1. & BEZIT11 & 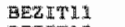 & & BEZITI & & & $p i c k-m p$ \\
\hline DEETTH & BEZIT1 & BETL12 & & BE: 2112 & & & x. actio \\
\hline 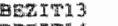 & BEZTTI3 & BEAT I 13 & & GEZTT13 & $B E_{2} T_{1}$ & & pianolongel \\
\hline EZIT14 & EEQTT14 & BEZITIA & & BEZTN" & B日st & & di aprojector \\
\hline 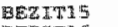 & 8 & EEZTEM & & EEZTTIS & BEZHTS & & E I Imoarme $\mathrm{ra}$ \\
\hline 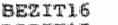 & DEZIF 6 & SEPIT16 & & BEZITIE & BE2I1: 6 & & 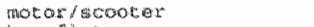 \\
\hline 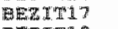 & BE: & BEZITI7 & & BEZTIII 1 & BEXITE & & bromf i be: \\
\hline EEDITI 8 & EEZTTH & BEZIT18 & BEZIT18 & EEZIT" & EERT $1 \mathrm{~T}$ & & alieo \\
\hline EEZT19 & DEZTTY 9 & DEPITI9 & & Degra & BE2 1919 & & bemgal owterent \\
\hline EE2 2020 & Bentra & SERTT20 & BEZ1 1 20 & BEZTT20 & BEZTT20 & & tweed won ing \\
\hline EETrar & 玨EIT21 & EEZIT2I & BEZTT21 & EEZTY 21 & 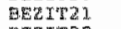 & & gatca- Catavaty \\
\hline 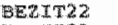 & EEZTT2Z & BERTM22 & BEZTT22 & BEZTT2Z & B⿺辶⿻一𠃋十 22 & & cour-caravan \\
\hline FEZIIZ3 & פEZTT23 & EEOZII23 & BEZTr23 & & DEETI23 & & tell $=$, mocorboot \\
\hline 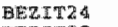 & SLE:T24 & BETIT24 & & BERTR2 & BEETT24 & & roalboot /kano \\
\hline BEZTE2 25 & & & & & EEZCLT25 & & Wideg omera \\
\hline \multicolumn{8}{|c|}{ Wersit tuat ie } \\
\hline WEFFI 1 & WERT 1 & WERKL & WWERXI & WER K.I. & MEER 1 & & becadat work. \\
\hline WERK2 & HERER 2 & WERK2 & WERK2 & WE. & WERR 2 & & Lugn per wekkerkzana \\
\hline WERE 3 & WERT & WER 3 & MVIRK 3 & WERRY & WIERT & & Londanet: \\
\hline WERTE & WERES & WESEKA & & WERKA & 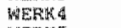 & & 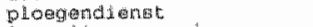 \\
\hline WEERS & WERKS & WEKS & 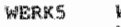 & WERTES & WEER 5 & & Lawa di ige ongeving \\
\hline WEERK 6 & WERKG & NERKG & & WERT 6 & WEDW 6 & & yulit wark \\
\hline HETER & WERET 7 & WERK & & WEFK & WEETE? & & Eebisduer \\
\hline WEEREB & & WER & WBRK & WERKB & WERKE & & Leidingevend \\
\hline WRK9 & & WERRS & WERK 9 & WERR9 & WEHKS & & promot i ekangan \\
\hline WEEK IO & & WERKOLO & WERK I0 & WERK 0 & WEFKIO & & atrik op merk \\
\hline WEREI 1 & & WERKII & WERTII & WERKR 1 & WERMLI & & gevalutidk wh \\
\hline WEER 2 & & HERK12 & WERK12 & WEFRHZ & WEAK12 & & zwat werk \\
\hline WERKIS & & WERK13 & WERK13 & WERR 3 & WEREX 3 & & hoog teano \\
\hline WERK14 & & MgRKI 4 & WEEEI 4 & WEKK 14 & 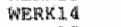 & & aentonig \\
\hline MERKIS & & & WERK 15 & WEFER 5 & 6月TERIS 5 & & cakertheid wert \\
\hline MERK 16 & & & WERKIL & WERE & WERK16 & & yoed salaras \\
\hline \multicolumn{8}{|c|}{ Burgerschap } \\
\hline Whet shoude: & & & & & & & \\
\hline$S A B E N \perp$ PDD & $\begin{array}{l}\text { SANEN_HD } \\
\text { OE_STAAF }\end{array}$ & OP_STHAT & $\begin{array}{l}\text { SAEEN_HD } \\
\text { OP_STAMT }\end{array}$ & $\begin{array}{l}\text { SAHEN } \\
\text { OP } S T A R T\end{array}$ & QP_STEA & 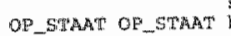 & 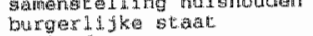 \\
\hline $\begin{array}{l}\text { DP_STHAT } \\
\text { FA }\end{array}$ & & & $\begin{array}{l}\text { OP_STAMT } \\
\text { FASE }\end{array}$ & PASE & FASE & & gezing faso \\
\hline READ & KMND & HWD & $\mathrm{K} \mathrm{IND}$ & KIND & & & kindaten \\
\hline \multicolumn{8}{|c|}{ Lidma is chappem } \\
\hline KIDL & Ti2 DI & LIDL & LTDI & 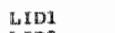 & LT:DI & & polltiok parti \\
\hline LuD2 & EID2 & $\angle L D Z$ & L.ID2 & $\mathrm{HID}$ & LIDT & & vakvereniging \\
\hline Lis & & $\mathrm{LrD} 3$ & & $\operatorname{StD} 3$ & LSD & & zág \\
\hline LIDE & Lid: DU & Q DE\& & & 2106 & $1 \mathrm{XD}$ & & mu 2 i e \\
\hline S.TS & & LDS & & MD5 & 1105 & & Longel \\
\hline L. TDE & Lat06 & LIDE & & LID6 & HDE & & godedirnotig doed \\
\hline LET & ED? & L $20 \%$ & & TID? & UIDJ & & Jeugdwerenting \\
\hline HัTES & $\operatorname{IDQB}$ & WIDE & & LDS: & LIDQ & & wroubaraterangling \\
\hline $\operatorname{Ling}$ & LID9 & LIDS & & LEOS & LID9 & & Bportwerditing \\
\hline SIDIO & LED & LIDU & & ETD 10 & LIDLO & & hobbyolub \\
\hline Ls TE: 1 & LEDI & I.ID11 & & UIDI & LTDIL & & overig \\
\hline $\mathrm{ETDA}$ & & L 1012 & & LIDI2 & $4 I 012$ & & biblintineak \\
\hline
\end{tabular}


Schema A Rubrieken van gebruikte wariabelen en hum woorkomen in de onderscheiden steekproeven van de Nederlandse Bevolking (vervolg)

\begin{tabular}{|c|c|c|c|c|c|c|c|c|}
\hline \multirow[b]{2}{*}{ 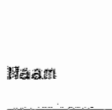 } & \multicolumn{5}{|l|}{ Survey } & \multicolumn{2}{|l|}{ Pand 1} & \multirow[b]{2}{*}{ Introted } \\
\hline & 1976 & 1977 & $\begin{array}{l}1980 \\
085\end{array}$ & $\begin{array}{l}1900 \\
300\end{array}$ & 1904 & 1981 & 293 & \\
\hline \multicolumn{9}{|c|}{ 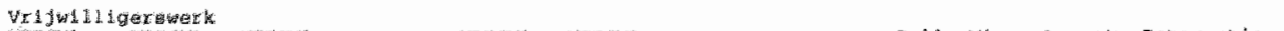 } \\
\hline VHIJWI & 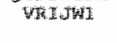 & Maghen & & varutat & 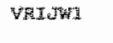 & & & 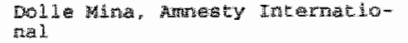 \\
\hline MALUW & Y⿸厂s & WRIJU & & VRTIMI & VRT JWI & & & Politiek \\
\hline 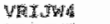 & 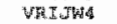 & YRI:HAH & & VI & 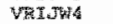 & & & Beroposorgandisation \\
\hline VETUWW & MAt JW & HII I J & & Vetows & MRIJings & & & 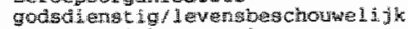 \\
\hline 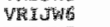 & VRTuthe & VRIJPAS & & VER $\mathrm{E}$ WW & YTH.JWG & & & zang, muzidex, toneel. \\
\hline VER TWT & & WRIJJP & & VR:IJW7 & 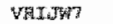 & & & owerig cutruted \\
\hline Vinu & VHe Swe & YMIJTHE & & 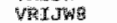 & UEI THE & & & pot \\
\hline 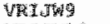 & VRITHS & WITW & & VER 30 & YEIJ ING & & & hobiby \\
\hline VWE WWIO & & WRIJTHO & & VRI.JU10 & VEL I W & & & onderw jo \\
\hline VHATHLOA & & & & 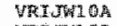 & & & & monol \\
\hline YEI ZWWOP & & & & 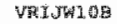 & & & & \\
\hline VWrot 1 & & WR I.JWL1 & & VR $\mathrm{E}$ JW1 1 & YRIJWH 1 & & & kimderopvang \\
\hline VRFWI 2 & VRINWL 2 & WRIJIII 2 & & VRISTIZ & VATJWHil 2 & & & jeugd, clubhu这 \\
\hline VFI, 13 & 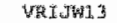 & WTIWLS & & YRT JW13 & HRT ob 13 & & & vrowarerenigung \\
\hline 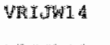 & VRTIUIA & WPT.TWL & & VRTSTH & YRXJTHI & & & $\begin{array}{l}\text { hulp aam buren, bejatrdan. } \\
\text { gehandicapten }\end{array}$ \\
\hline 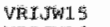 & & & & & MRTuWa & & & vinow thigrop, - cate \\
\hline VET, IWI 6 & UER IJW1. 6 & VRLSWL 6 & & MRUWI的 & YRI I WNA 6 & & & onerig \\
\hline VFIITH 17 & & WRI:JWI & & & & & & 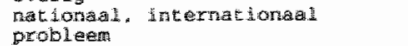 \\
\hline VETJWIS & & WARWWL & & & & & & lokad pobleam \\
\hline Gebtulk & \multicolumn{5}{|c|}{ 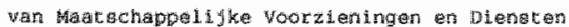 } & & & \\
\hline volorit & voon: 1 & & & vooter 1 & YOORZZ & & & alg. natson. werk \\
\hline Vôk2Z & VOOR22 & & & Voonz 2 & MoOg:2 2 & & & beadrijfanatech, werk \\
\hline VoOR2 3 & voonz 3 & WoOR23 & & VDOR23 & WOORZ 3 & & & getn. soc. dienst \\
\hline Voove & VODORZA & WoORz 4 & & Yoopers of & VOORZ & & & gezingzorg \\
\hline VoON25 & VOOR2S & & & VODRES & Woorzs & & & dienstencenterubejaarden \\
\hline VoOger & VoOnz 6 & & & vookz & VOOR:E & & & bureau tevenskezinurgen \\
\hline Vooken & VOORZ7 & WOQRZ7 & & voonz? & Voor27 & & & Med. Opvodik. Buro \\
\hline VoOHZ & VOORZY & & & VOORE & MOORZB & & & Imst. Med. Pgychthematie \\
\hline VONOHZ & VoORES & & & VODRZS & VOOREY & & & Soc. Paychiatische buenot \\
\hline VOOR210 & & & & VOORR10 & Voon210 & & & Krulisvereniging \\
\hline voOR2 1 & VOORZII & & & VOOR211. & VOORZ11 & & & Wi j kverpleging \\
\hline VoO朋 81.2 & & Wookz12 & & VOORZ12 & YOORZ12 & & & Kramatis \\
\hline VOORZ13 & voome13 & & & Vogtad 13 & MOORZ 13 & & & Cons. Bureal Geb regeling \\
\hline VOOPI 14 & VOORzI4 & Yookgid & & YOORZ14 & VODRZI & & & Soctal Radoman \\
\hline VOOPZ15 & VOOR2: 5 & & & VOORE & VOORZ 15 & & & Wetskink 1 \\
\hline VCota 246 & VOORE 15 & & & voof 216 & WOORZ I. & & & JAC, Reterse \\
\hline vootrizi 7 & VoOrq17 & & & VOORZ17 & VOORZ17 & & & Tel. hulpoi ensten \\
\hline VOOFE 1.8 & & & & VOORZZ 1 D & NOORZL: & & & Cons. Bureau Alic. Drugs \\
\hline
\end{tabular}

Tabel 1 Aantal chronisch zleke hoofden van hutshoudens (\%) in de Nederlandse bevolking 1974-1983

\begin{tabular}{|c|c|c|c|c|c|c|c|}
\hline \multirow[b]{2}{*}{ Besterna } & \multicolumn{5}{|c|}{ Survay } & \multicolumn{2}{|c|}{ Panel } \\
\hline & 1974 & 1977 & $\begin{array}{l}1.980 \\
\text { Cas }\end{array}$ & $\begin{array}{l}1980 \\
\operatorname{sep}\end{array}$ & 1983 & 1981 & 1983 \\
\hline Chronigeh ziek & 32.1 & 54.4 & 33.7 & 46.0 & 49.0 & 26.3 & 24.5 \\
\hline $\begin{array}{l}\mathbb{N} \\
\text { ontbrekende }\end{array}$ & 1966 & 1767 & 1584 & 1498 & 1537 & 499 & 498 \\
\hline wa atneni ngen & & & 15 & & 73 & & 1 \\
\hline
\end{tabular}


Tabel 2 Geloof en poltiek voorkeur van hoofden van hushoudens (s) in surveys en panel

\begin{tabular}{|c|c|c|c|c|c|c|c|}
\hline \multirow[b]{2}{*}{ Bestand } & \multicolumn{5}{|l|}{ Survery } & \multicolumn{2}{|l|}{ Paned } \\
\hline & 1974 & 1977 & $\begin{array}{l}1980 \\
\operatorname{CBS}\end{array}$ & $\begin{array}{l}1980 \\
\operatorname{scP} \\
\end{array}$ & 1983 & 1981 & 1983 \\
\hline \multicolumn{8}{|l|}{ A. Geloof } \\
\hline $\begin{array}{l}\text { Rooms kathol iek } \\
\text { grotestant } \\
\text { arders } \\
\text { geen }\end{array}$ & $\begin{array}{r}34.3 \\
26.3 \\
3.2 \\
36.3\end{array}$ & $\begin{array}{r}36.8 \\
31.5 \\
3.8 \\
28.0\end{array}$ & $\begin{array}{r}34.0 \\
27.8 \\
3.2 \\
32.1\end{array}$ & $\begin{array}{r}35.3 \\
30.4 \\
5.5 \\
28.8\end{array}$ & $\begin{array}{r}37.2 \\
27.8 \\
5.1 \\
30.0\end{array}$ & $\begin{array}{r}33.2 \\
26.2 \\
4.6 \\
36.0\end{array}$ & 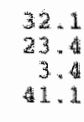 \\
\hline $\begin{array}{l}\text { Total } \\
\text { ontbrekende warnemingen }\end{array}$ & 1960 & $\begin{array}{r}1744 \\
23\end{array}$ & $\begin{array}{r}1586 \\
13\end{array}$ & $\begin{array}{r}1494 \\
4\end{array}$ & $\begin{array}{r}1606 \\
4\end{array}$ & $\begin{array}{r}497 \\
2\end{array}$ & $\begin{array}{r}496 \\
3\end{array}$ \\
\hline \multicolumn{8}{|l|}{$\begin{array}{l}\text { B. politieke overtuighng } \\
\text { politieke voorkeur }\end{array}$} \\
\hline Pvid & 26.5 & 24.8 & 24.5 & & 26.9 & 27.4 & 31.3 \\
\hline CDA & 22.0 & 26.6 & 37.0 & & $25 \cdot 2$ & $27 \cdot 1$ & 27.4 \\
\hline WVD & $15 . \frac{4}{*}$ & 16.3 & 14.9 & & 20.1 & 15.3 & 22.6 \\
\hline$D=66$ & .9 & 3.6 & 12.1 & & 2.5 & 13.0 & 2.5 \\
\hline Kein links & 6.3 & 3.5 & 4.2 & & $4 \cdot 1$ & 5.0 & 6.5 \\
\hline $\begin{array}{l}\text { kiein rechts } \\
\text { confessioneel }\end{array}$ & .8 & .4 & .5 & & .3 & .2 & 1.0 \\
\hline $\begin{array}{l}\text { reats } \\
\text { goen voorkeur }\end{array}$ & $\begin{array}{r}6 \cdot 2 \\
22 \cdot 1\end{array}$ & 21.4 & 6.7 & & $\begin{array}{r}3.2 \\
17 \cdot 6\end{array}$ & $\begin{array}{l}4.5 \\
7.5\end{array}$ & $\begin{array}{l}3.6 \\
2.5\end{array}$ \\
\hline Total & 1863 & 1671 & 1320 & & 1545 & 424 & 395 \\
\hline Ontbrekende waarnemingen & 103 & 96 & 279 & 1498 & 65 & 75 & 103 \\
\hline
\end{tabular}

Tabel 3 Frequent uitgewoerde activiteiten in de vrije tijd

\begin{tabular}{|c|c|c|c|c|c|}
\hline \multirow[b]{2}{*}{ Bestand } & \multicolumn{5}{|c|}{ Survey } \\
\hline & 1974 & 1977 & $\begin{array}{l}1980 \\
\text { C85 }\end{array}$ & $\begin{array}{l}1980 \\
\text { SCP }\end{array}$ & 1983 \\
\hline 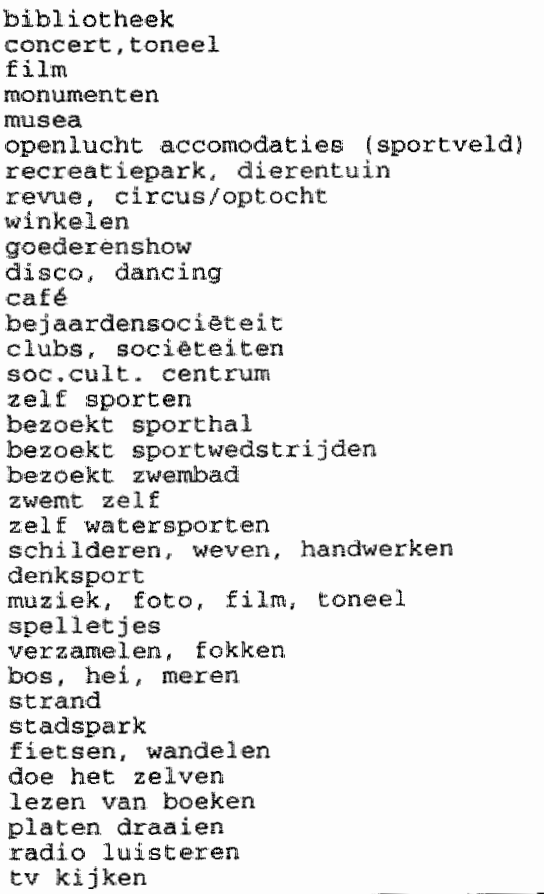 & $\begin{array}{r}8.3 \\
5.5 \\
16.0 \\
7.7 \\
19.3 \\
7.5 \\
8.6 \\
3.9 \\
17.5 \\
9.2 \\
14.6 \\
24.2 \\
26.4 \\
40.4 \\
7.9 \\
43.8 \\
75.9 \\
33.8 \\
47.1 \\
51.8\end{array}$ & $\begin{array}{r}15.0 \\
4.8 \\
5.0 \\
6.5 \\
3.7 \\
37.0 \\
3.2 \\
.7 \\
12.3 \\
1.5 \\
3.5 \\
2.6 \\
11.6 \\
26.9 \\
32.9 \\
1.4 .2 \\
46.1 \\
21.4 \\
5.8 \\
6.3 \\
3.7 \\
39.4 \\
23.7 \\
40.4\end{array}$ & & $\begin{array}{r}14.1 \\
6.3 \\
5.8 \\
8.3 \\
4.3 \\
16.3 \\
4.1 \\
1.0 \\
15.7 \\
2.8 \\
5.1 \\
5.5 \\
2.6 \\
7.8 \\
3.9 \\
21.1 \\
14.4 \\
15.4 \\
10.5 \\
9.2 \\
5.0 \\
25.3 \\
9.7 \\
16.0 \\
2.13 \\
25.3 \\
29.8\end{array}$ & $\begin{array}{r}15.5 \\
3.4 \\
3.4 \\
10.0 \\
5.5 \\
20.1 \\
4.8 \\
.9 \\
15.6 \\
3.3 \\
2.4 \\
6.6 \\
1.6 \\
8.4 \\
5.2 \\
24.8 \\
16.7 \\
17.9 \\
8.6 \\
7.6 \\
5.2 \\
17.8 \\
11.4 \\
16.6 \\
24.0 \\
30.0 \\
31.1 \\
12.2 \\
0.1 \\
51.2 \\
41.5 \\
83.3 \\
37.8 \\
54.2 \\
62.5\end{array}$ \\
\hline
\end{tabular}


Tabel 4 Kenmerken van de woning wan hootden van huilehoudens $(\%)$ maar bestand

\begin{tabular}{|c|c|c|c|c|c|c|c|c|}
\hline \multirow[b]{2}{*}{ Bugation } & \multicolumn{5}{|c|}{ Survey } & \multicolumn{2}{|c|}{ Panel } & \multirow[b]{2}{*}{ 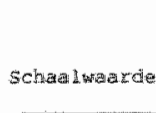 } \\
\hline & $1.9 \%$ & $15 \% 7$ & $\begin{array}{l}\text { 19.9. } \\
\text { Cos }\end{array}$ & $\begin{array}{l}1980 \\
500 \\
505\end{array}$ & 1503 & 901 & 1953 & \\
\hline 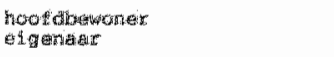 & $\begin{array}{l}99.4 \\
42.0\end{array}$ & $\begin{array}{l}96.6 \\
46:-4.6\end{array}$ & $\begin{array}{l}95.8 \\
53.8\end{array}$ & 53.3 & $\begin{array}{l}79.4 \\
48.3\end{array}$ & & & -6.53 \\
\hline 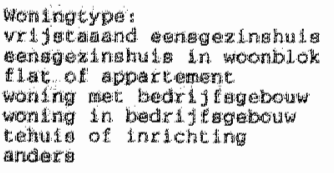 & $\begin{array}{r}18.7 \\
22.7 \\
23.9 \\
3.3 \\
1.8 \\
.7 \\
.9\end{array}$ & $\begin{array}{r}18: 2 \\
52.4 \\
2.4 \\
1.3 \\
0.4 \\
1.3 \\
1.6\end{array}$ & $\begin{array}{l}23.1 \\
52.0 \\
2.4 .9 \\
1.6 \\
2.1 \\
1.1 \\
6.4\end{array}$ & $\begin{array}{l}15 \cdot 2 \\
50.1 \\
23.6 \\
1.7 \\
1.7 \\
2.7 \\
4.7\end{array}$ & $\begin{array}{r}19.8 \\
57.2 \\
19.2 \\
3.0 \\
2.2 \\
2.9\end{array}$ & & & $\begin{array}{r}.55 \\
-.5 \\
-.93 \\
-1.27 \\
-1 . .58 \\
-.98 \\
-.62\end{array}$ \\
\hline 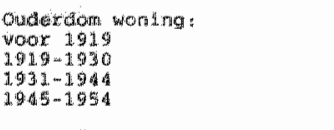 & $\begin{array}{r}12.6 \\
9.6 \\
11.6 \\
31.4\end{array}$ & $\begin{array}{r}12.4 \\
8.2 \\
10.2 \\
27.4\end{array}$ & $\begin{array}{r}13.6 \\
9.9 \\
10.6 \\
7.6\end{array}$ & $\begin{array}{r}1.4 .6 \\
9.1 \\
9.1 \\
7.8\end{array}$ & $\begin{array}{l}9.6 \\
7.9 \\
8.3 \\
8.6\end{array}$ & & & \\
\hline 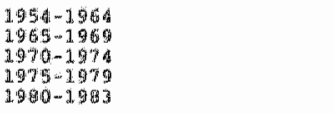 & 3.4 .7 & $\begin{array}{r}1.5 .8 \\
1.8 .3 \\
7.2\end{array}$ & $\begin{array}{l}16.3 \\
12.1 \\
17.6 \\
13.2\end{array}$ & $\begin{array}{l}16.2 \\
14.2 \\
16.0 \\
14.2\end{array}$ & $\begin{array}{r}15.2 \\
1.1 .9 \\
17.1 \\
13.6 \\
8.3\end{array}$ & & & \\
\hline 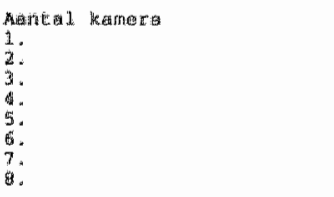 & & $\begin{array}{r}3.3 \\
1.3 .0 \\
3.9 .9 \\
2.7 .5 \\
9.7 \\
3.2 \\
1.5\end{array}$ & 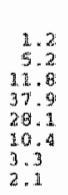 & & $\begin{array}{r}2.0 \\
6.3 \\
10.4 \\
20.5 \\
31.0 \\
23.0 \\
4.6 \\
3.5\end{array}$ & $\begin{array}{r}2.1 \\
9.9 \\
41.5 \\
30.6 \\
10.4 \\
3.0 \\
1.9\end{array}$ & & $\begin{array}{r}-1.09 \\
-.78 \\
-.47 \\
-.15 \\
.115 \\
.77 \\
.79 \\
.79\end{array}$ \\
\hline \multicolumn{9}{|c|}{ 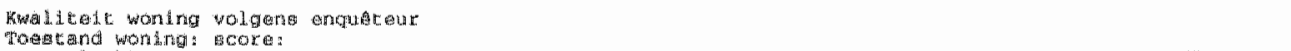 } \\
\hline 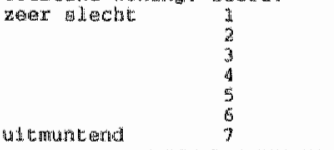 & $\begin{array}{r}2.9 \\
5: 2 \\
10.2 \\
23.6 \\
34.7 \\
23.2\end{array}$ & $\begin{array}{r}3.0 \\
3.6 \\
8.5 \\
2.5 \\
18.2 \\
19.2 \\
29.5\end{array}$ & & & $\begin{array}{r}.9 \\
1.9 \\
4.5 \\
9.9 \\
14.6 \\
19 \times 1 \\
49.0\end{array}$ & $\begin{array}{r}1.9 \\
6.0 \\
1.5 .9 \\
24.3 \\
26.5 \\
24.9\end{array}$ & & $\begin{array}{r}-6.53 \\
-2.06 \\
-1.43 \\
-0.38 \\
0.08 \\
0.08 \\
0.66\end{array}$ \\
\hline
\end{tabular}

Tabel 5. Kenmerken van de werksituatie van hoofdem van huishoudens (\%) maar bestand

\begin{tabular}{|c|c|c|c|c|c|c|c|}
\hline \multirow[b]{2}{*}{ 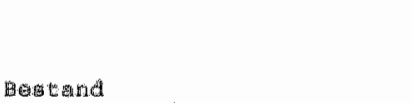 } & \multicolumn{5}{|c|}{ Survey } & \multicolumn{2}{|l|}{ Panel } \\
\hline & 197 & 1977 & 1980 & 1980 & 1983 & 1981 & 1983 \\
\hline 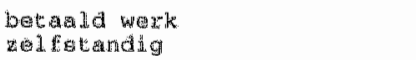 & $\begin{array}{l}84.6 \\
18.6\end{array}$ & $\begin{array}{l}70.7 \\
1.2 .2\end{array}$ & $\begin{array}{l}66.1 \\
12.3\end{array}$ & $\begin{array}{l}67.2 \\
12.1\end{array}$ & $\begin{array}{l}69.0 \\
10.4 .\end{array}$ & *. & . \\
\hline 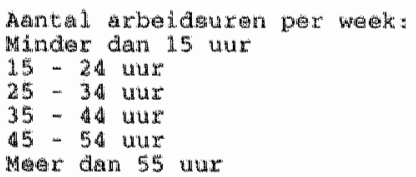 & $\begin{array}{r}.9 \\
2.2 \\
96.9 \\
16.5\end{array}$ & 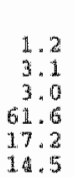 & $\begin{array}{r}1 \cdot 1 \\
3 \cdot 2 \\
2 \cdot 9 \\
60.7 \\
15.6 \\
14.9\end{array}$ & $\begin{array}{r}1.2 \\
3.2 \\
4.0 \\
62.2 \\
9.8 \\
13.8\end{array}$ & $\begin{array}{r}3.1 \\
1.5 \\
3.6 \\
69.8 \\
12.3\end{array}$ & & \\
\hline 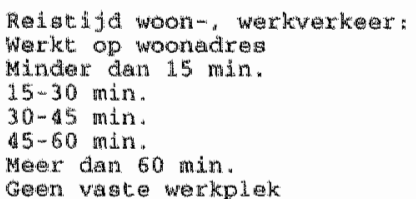 & $\begin{array}{r}10.5 \\
30.8 \\
31.5 \\
10.5 \\
3.4 \\
5.3\end{array}$ & $\begin{array}{r}9.3 \\
30.4 \\
25 \cdot 6 \\
12.5 \\
5.4 \\
7.7\end{array}$ & & $\begin{array}{r}10.3 \\
39 \cdot 5 \\
27.2 \\
11.2 \\
5 \cdot 5 \\
6.2\end{array}$ & $\begin{array}{r}8.2 \\
33.6 \\
26.3 \\
12.9 \\
7.7 \\
5.8 \\
7.6\end{array}$ & & \\
\hline
\end{tabular}




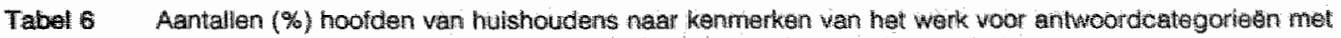

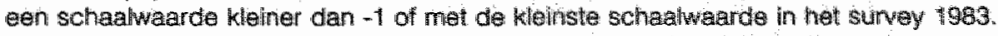

\begin{tabular}{|c|c|c|c|c|c|c|c|}
\hline \multirow[b]{2}{*}{ Rest酒o } & \multicolumn{5}{|c|}{ Surver } & \multicolumn{2}{|l|}{ Pand } \\
\hline & 1974 & 197 & $\begin{array}{l}1980 \\
\mathrm{~m} n \mathrm{Bg}\end{array}$ & $\begin{array}{l}1980 \\
\text { scop }\end{array}$ & 1993 & 1981 & 1963 \\
\hline $\begin{array}{l}\text { Werk is: } \\
\text { pLogemdienst } \\
\text { lawalig } \\
\text { vil } \\
\text { zwaar } \\
\text { stank } \\
\text { gevaarlijk } \\
\text { eertomig } \\
\text { hoog tempo }\end{array}$ & $\begin{array}{r}9 i \cdot 7 \\
27.3 \\
30.5\end{array}$ & $\begin{array}{r}9.9 \\
30.7 \\
34.0 \\
19.9 \\
12.0 \\
24.4 \\
4.6 \\
13.0\end{array}$ & $\begin{array}{r}22.0 \\
12.6 \\
13.3 \\
25.6 \\
4.5 \\
28.5\end{array}$ & $\begin{array}{r}9.2 \\
25.9 \\
31.0 \\
21.1 \\
12.1 \\
27.2 \\
3.7 \\
13.0\end{array}$ & $\begin{array}{r}11.1 \\
25.9 \\
29.0 \\
23.2 \\
11.0 \\
26.7 \\
3.9 \\
11.2\end{array}$ & & \\
\hline
\end{tabular}

Tabel 7 Werkomstandigheden van hoofden van huishoudens (\%) naar bestand

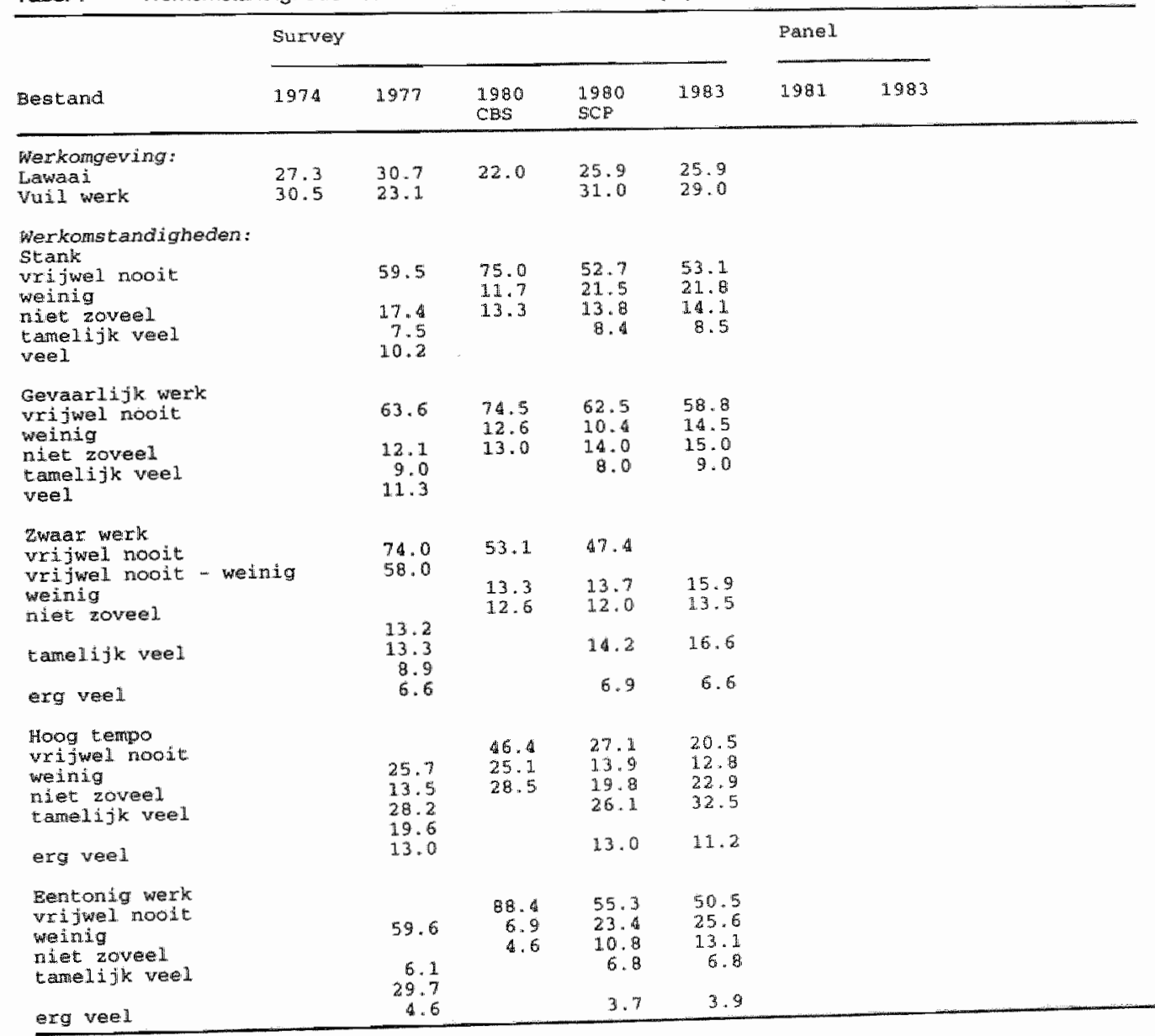


Tabel B Bezt van goederen onder hoolden van hushoudens (\%) naar bestand

\begin{tabular}{|c|c|c|c|c|c|}
\hline \multirow[b]{2}{*}{ E\&g: tal } & \multicolumn{5}{|c|}{ gurvey } \\
\hline & 1973 & 1977 & $\begin{array}{l}1900 \\
\text { CDS }\end{array}$ & $\begin{array}{l}1980 \\
9 C P\end{array}$ & 2583 \\
\hline Luxe bezat & & & & & \\
\hline 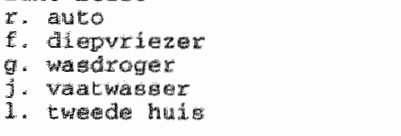 & $\begin{array}{r}69.5 \\
24.0 \\
9.5 \\
6.7 \\
1.4\end{array}$ & $\begin{array}{r}6.2 \\
41.0 \\
10 \cdot 0 \\
10.41 \\
2 \cdot 3\end{array}$ & $\begin{array}{r}69.8 \\
15 \cdot 3 \\
11.3 \\
3.0\end{array}$ & $\begin{array}{r}70.7 \\
13.7 \\
13.9 \\
2.7\end{array}$ & $\begin{array}{r}79.4 \\
58.4 \\
19.5 \\
12.0 \\
2.7\end{array}$ \\
\hline 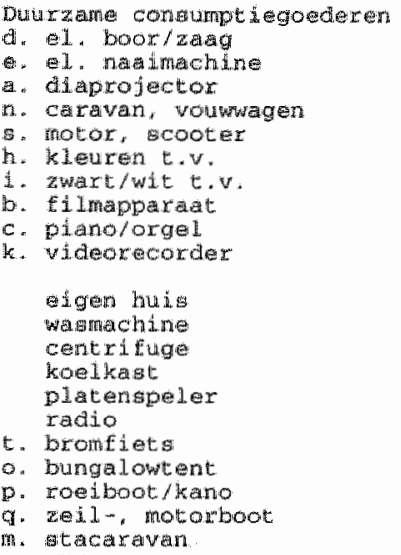 & $\begin{array}{r}91.9 \\
7.4 .6 \\
94.5 \\
73.0 \\
96.9 \\
30.7 \\
9.5 \\
3.4 \\
3.6 \\
1.5\end{array}$ & $\begin{array}{l}90.0 \\
80.2 \\
96.8 \\
84.0 \\
90.0 \\
19.6 \\
12.1 \\
5.8 \\
5.6 \\
3.0\end{array}$ & $\begin{array}{r}6.4 \\
70.7\end{array}$ & $\begin{array}{r}86.9 \\
64.2 \\
96.7 \\
86.2 \\
97.9 \\
15.6 \\
8.4 \\
3.9 \\
2.9\end{array}$ & $\begin{array}{r}76.4 \\
75.2 \\
27.0 \\
9.5 \\
2.4 \\
8.43 \\
38.9 \\
22.2 \\
16.9 \\
10.8 \\
51.7\end{array}$ \\
\hline
\end{tabular}

Tabal $9 \quad$ Burgerlike staat van hootden van huishoudens (\%) naar bestand

\begin{tabular}{|c|c|c|c|c|c|c|c|}
\hline \multirow[b]{2}{*}{ Bestand } & \multicolumn{5}{|c|}{ SWIVWOY } & \multicolumn{2}{|c|}{ Pañel } \\
\hline & 1974 & 1977 & $\begin{array}{l}1980 \\
\mathrm{CBS}\end{array}$ & $\begin{array}{l}1.900 \\
3 \mathrm{CP}\end{array}$ & 1983 & 1901 & 1983 \\
\hline 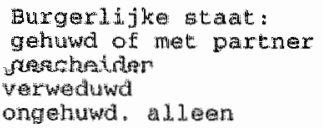 & $\begin{array}{c}93.9 \\
4.3^{2} \\
4.3 \\
1.0\end{array}$ & $\begin{array}{r}78.4 \\
2.3^{2} \\
12.7 \\
6.5\end{array}$ & $\begin{array}{r}71.8 \\
4.4 \\
11.6 \\
12.2\end{array}$ & $\begin{array}{r}71.4 \\
4.6 \\
12.6 \\
12.8\end{array}$ & $\begin{array}{l}9.8 \\
3 \cdot y^{4} \\
4 \cdot 2 \\
7.1\end{array}$ & $\begin{array}{r}75.1 \\
3.4 \\
8.7 \\
11.9\end{array}$ & $\begin{array}{r}73.8 \\
7.5 \\
10.5 \\
8.3\end{array}$ \\
\hline
\end{tabular}

Tabel to Percentage Hoofden van Huishoudens dat lid is van bepaalde verenigingen

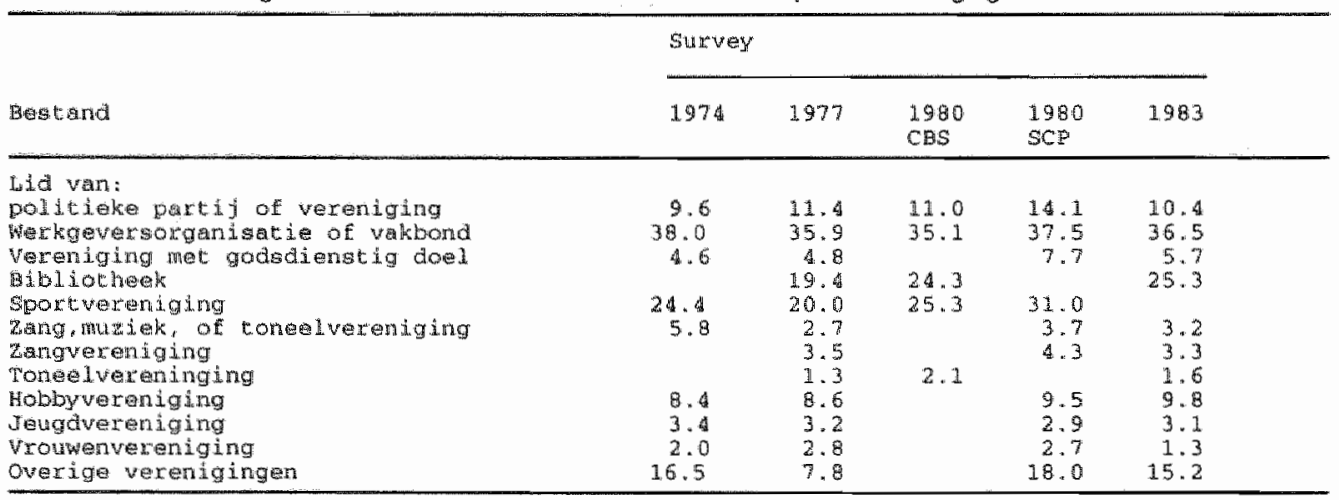


Tabel 11 Percentage hookden van huishoudens dat whilwilligerswerkj doer

\begin{tabular}{|c|c|c|c|c|c|}
\hline \multirow[b]{2}{*}{ Segtand } & \multicolumn{5}{|c|}{ Survey } \\
\hline & 1974 & 1977 & $\begin{array}{l}1980 \\
\text { C.SS }\end{array}$ & $\begin{array}{l}190 \\
9 C \mathrm{P}\end{array}$ & 1983 \\
\hline $\begin{array}{l}\text { Activleste: } \\
\text { akt iegroepen, wereldwinkel, } \\
\text { annesty internationa? }\end{array}$ & $7 \times 2$ & 2.6 & & 3.1 & $3 \cdot 2$ \\
\hline 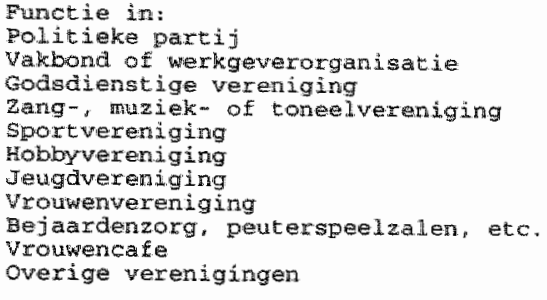 & $\begin{array}{r}1.4 \\
4.9 \\
3.1 \\
3.3 \\
12.5 \\
3.0 \\
2.1 \\
1.7 \\
10.1 \\
0.5\end{array}$ & $\begin{array}{r}2.8 \\
5.0 \\
7.8 \\
3.8 \\
11.1 \\
8.1 \\
3.7 \\
9.5 \\
5.5 \\
5.1\end{array}$ & & $\begin{array}{r}4.9 \\
8.7 \\
20.9 \\
6.7 \\
17.3 \\
18.3 \\
4.5 \\
2.2 \\
7.6 \\
9.8\end{array}$ & $\begin{array}{r}3.2 \\
7.6 \\
10.1 \\
6.2 \\
20.3 \\
11.5 \\
4.2 \\
.5 \\
5.6 \\
.1 \\
3.1\end{array}$ \\
\hline $\begin{array}{l}\text { Orbetald werk: } \\
\text { Orderwijs } \\
\text { Kinderopwing } \\
\text { overig culeureel. }\end{array}$ & & $\begin{array}{l}5.3 \\
1.2 \\
2.9\end{array}$ & & $\begin{array}{l}7.5 \\
2.0 \\
4.6\end{array}$ & $\begin{array}{r}.6 \\
: 5 \\
0.3\end{array}$ \\
\hline
\end{tabular}

Tiabel 12 Percentage hoofden wan huishoudens dat gebruik maakt van bepaalde woorzieningen

\begin{tabular}{|c|c|c|c|c|c|}
\hline \multirow[b]{2}{*}{ Bestand } & \multicolumn{5}{|c|}{ Survay } \\
\hline & 1974 & 1977 & $\begin{array}{l}1980 \\
\mathrm{CBS}\end{array}$ & $\begin{array}{l}1980 \\
5 C P\end{array}$ & 1983 \\
\hline 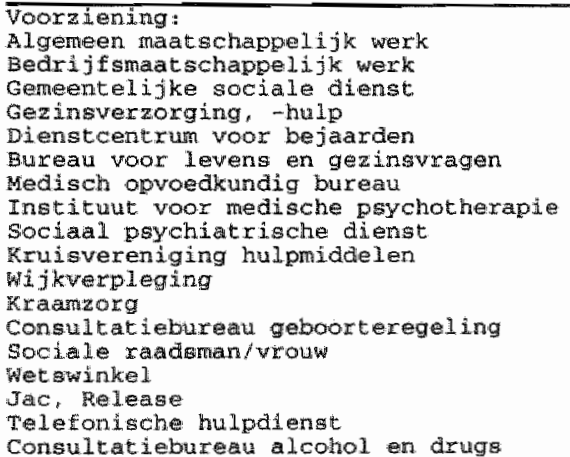 & $\begin{array}{r}2.1 \\
1.5 \\
7.6 \\
5.5 \\
.6 \\
.3 \\
.9 \\
.5 \\
.8 \\
12.3 \\
.8 \\
81.3 \\
.3 \\
.1\end{array}$ & $\begin{array}{l}1.4 \\
1.9\end{array}$ & & $\begin{array}{l}2.5 \\
1.1 \\
5.1 \\
4 \cdot 1 \\
1.6 \\
.8 \\
1.5 \\
1.5 \\
1.2 \\
5.9 \\
5.2 \\
2.1 \\
.7 \\
2.2 \\
2.7 \\
.1 \\
.1 \\
.2\end{array}$ & $\begin{array}{r}3.3 \\
2.6 \\
0.7 \\
4.1 \\
.6 \\
.7 \\
1.0 \\
2.2 \\
1.7 \\
10.9 \\
6.9 \\
2.2 \\
1.4 \\
2.6 \\
2.9 \\
.1 \\
.2 \\
.3\end{array}$ \\
\hline
\end{tabular}




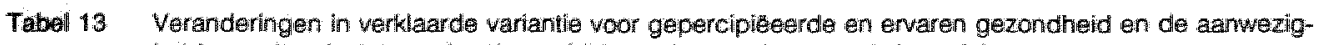
heid wan chronische aandoeningen bij invouring vari het cumulatiemodel.

\begin{tabular}{|c|c|c|c|c|c|c|c|}
\hline \multirow[b]{2}{*}{ Butand } & \multicolumn{5}{|c|}{ Switey } & \multicolumn{2}{|c|}{ panes } \\
\hline & 1974 & 5977 & $\begin{array}{l}1980 \\
C .95\end{array}$ & $\begin{array}{l}2900 \\
560\end{array}$ & 2983 & 1981 & 293 \\
\hline \multicolumn{8}{|l|}{ 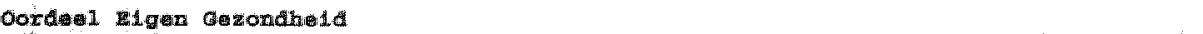 } \\
\hline actulum rond & .049 & .129 & .011 & .101 & .164 & .73 & .035 \\
\hline 815 & .021 & .022 & .038 & .042 & .013 & .013 & .036 \\
\hline 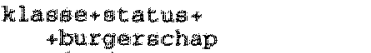 & .046 & .034 & $* 007$ & .061 & 044 & .055 & .005 \\
\hline \multicolumn{8}{|l|}{ Cunulation } \\
\hline Xlats 86 & .004 & .000 & .002 & .001 & .001 & 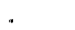 & . \\
\hline Stutede & .002 & .001 & .001 & .000 & .001 & .001 & .020 \\
\hline 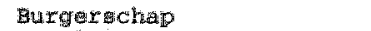 & .011 & .003 & . & .009 & .014 & . & 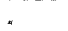 \\
\hline Totalial & 133 & 190 & 160 & .217 & .237 & .141 & .276 \\
\hline adjuted $\mathrm{R}^{2}$ & .109 & .163 & 141 & .189 & .196 & .072 & .115 \\
\hline \multicolumn{8}{|l|}{ 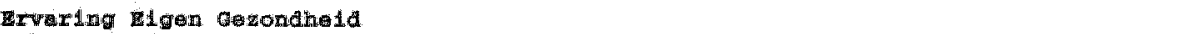 } \\
\hline chtergrond & .0 .2 & .0158 & .081 & .099 & 100 & .079 & .027 \\
\hline SES & .014 & .025 & .028 & .043 & .01. & .059 & .035 \\
\hline 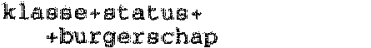 & .042 & .0160 & .086 & .061 & .44 & .035 & .099 \\
\hline \multicolumn{8}{|l|}{ Cumulat 10} \\
\hline Flatese & .001 & .001 & .002 & .001 & .001 & & \\
\hline status a & .002 & 001 & .001 & .004 & .001 & .004 & .020 \\
\hline Bunger chap & .020 & .006 & & .008 & .014 & & \\
\hline Totuma 1 & .111 & .169 & .259 & .216 & .235 & .176 & .171 \\
\hline Adyuged $\mathbb{R}^{2}$ & .086 & .41 & .141 & .189 & .194 & $=110$ & 112 \\
\hline \multicolumn{8}{|l|}{ dhroind the zioktan } \\
\hline achterg nond & .095 & .064 & .065 & .077 & .087 & .124 & .116 \\
\hline SES & .005 & .005 & .032 & .000 & .007 & .022 & .002 \\
\hline 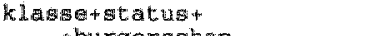 & $.02 \frac{1}{4}$ & .034 & .037 & .021 & .060 & .081 & .062 \\
\hline \multirow{2}{*}{\multicolumn{8}{|c|}{ Cumulats: }} \\
\hline & & & & & & & \\
\hline Kl 1 ase & .002 & .001 & .004 & .000 & .002 & & \\
\hline Status & .001 & .000 & .001 & .007 & .002 & .024 & .002 \\
\hline Burgerschap & .011 & .022 & .005 & .015 & .011 & & \\
\hline Totmal R & .103 & .124 & .139 & .131 & .168 & .251 & .102 \\
\hline $\mathrm{R}$ & .32 & .35 & .37 & .36 & .41 & .50 & .43 \\
\hline
\end{tabular}

P<. 10; 405 
Tabel 14 Samenhang ( $\beta$ ) van cumulatiekenmerken met gepercipiearde en orvangn gezondhoid

\begin{tabular}{|c|c|c|c|c|c|c|c|}
\hline \multirow[b]{2}{*}{ Bestard } & \multicolumn{5}{|l|}{ Shrvey } & \multicolumn{2}{|l|}{ Putition } \\
\hline & $197 \mathrm{~d}$ & 1977 & $\begin{array}{l}1980 \\
6.98\end{array}$ & $\begin{array}{l}1980 \\
302\end{array}$ & 198 & 151 & 1983 \\
\hline \multicolumn{8}{|l|}{ 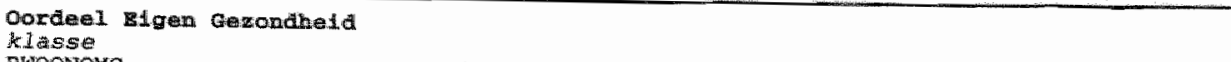 } \\
\hline EWOONOMG & -.018 & & -.039 & & .00 & & \\
\hline RWWWARK & .091 & -.013 & -.134 & .029 & .078 & & \\
\hline \multicolumn{8}{|l|}{ stmatus } \\
\hline RSPRTCLT & .210 & .084 & & .112 & 1076 & & \\
\hline RONTES & & & -.044 & -.052 & .013 & .041 & .136 \\
\hline \multicolumn{5}{|l|}{ Burgerschap } & +023 & .024 & 095 \\
\hline RLTIMIS & .052 & .069 & & .035 & -.126 & & \\
\hline RLIDM13 & -.042 & $=04$ & & $\begin{array}{l}.035 \\
.041\end{array}$ & .050 & & \\
\hline RLIDHZ3 & -.085 & -.003 & & .213 & .182 & & \\
\hline RIDOM123 & -.017 & -.092 & & -0.62 & -.181 & & \\
\hline RWRY 12 & .039 & .058 & & -.076 & -.065 & & \\
\hline RVINEI3 & .029 & .029 & & .050 & .134 & & \\
\hline RVRY23 & -096 & -.004 & & -.016 & -.03 & & \\
\hline RWEY 23 & .054 & .008 & & -127 & .100 & & \\
\hline ROOR 12 & -.026 & -.234 & & .082 & .046 & & \\
\hline RVOOOR 13 & .061 & .230 & & -.061 & .104 & & \\
\hline RVOOR23 & .279 & .070 & & .076 & -.003 & & \\
\hline RVOOR123. & -.070 & .107 & & ${ }^{4} 028$ & .045 & & \\
\hline \multicolumn{8}{|l|}{$\begin{array}{l}\text { Hisvisen Gezondmid (Vomo) } \\
\text { klasse }\end{array}$} \\
\hline RHOONOMG & -.012 & & .043 & & -.113 & & \\
\hline RWRVINRK & -.046 & .108 & .020 & -012 & -.084 & & \\
\hline RDOUREUUX & -.106 & .000 & -.355 & -233 & -.156 & & \\
\hline \multicolumn{8}{|l|}{ sto tus } \\
\hline RSPRTCLT & -.201 & -.097 & & -.100 & .096 & & \\
\hline RONWTHOUD & & & .034 & .002 & .007 & -.058 & -.315 \\
\hline RGEBRUTK & & & -.013 & $-0 A d$ & -.023 & .077 & .033 \\
\hline \multicolumn{8}{|l|}{ burgesschap } \\
\hline RLIDH 12 & -.057 & -.032 & & $\approx 101$ & .092 & & \\
\hline REIDMU 3 & .040 & .015 & & .005 & -.124 & & \\
\hline RLIDH 23 & .012 & .124 & & -.008 & -.044 & & \\
\hline REIDH 123 & .003 & -.095 & & .040 & .101 & & \\
\hline RVRY12 & .001 & .055 & & .04 & .001 & & \\
\hline RVRY 3 & -.018 & -.113 & & .049 & .105 & & \\
\hline RWRY23 & .100 & -.089 & & .082 & .206 & & \\
\hline RWRY 23 & -.082 & .092 & & .054 & -.169 & & \\
\hline RWOOR12 & .090 & .225 & & .001 & -.066 & & \\
\hline RVOORI 3 & -041 & -.143 & & -.019 & .022 & & \\
\hline RVOOR23 & -478 & -.167 & & -.036 & -130 & & \\
\hline RVOOR 123 & -.171 & -018 & & -.011 & -.046 & & \\
\hline
\end{tabular}

Tabol 15 Samenhang (b) van cumulattetemen met de aanwezigheid wan chronische ziøklan

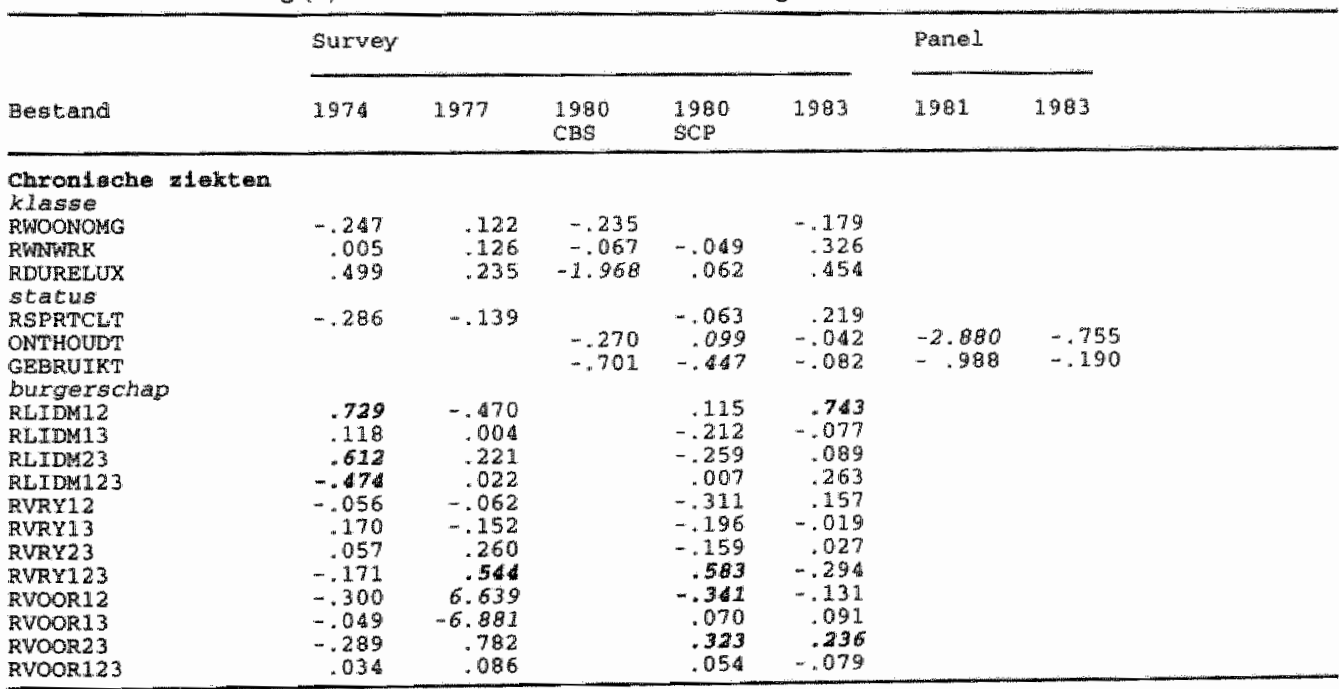


Tabel 16 Veranderingen in verklaarde wariantie voor geperctpiëerde en envaren gezondheid bij invoering van het consistentiemodel

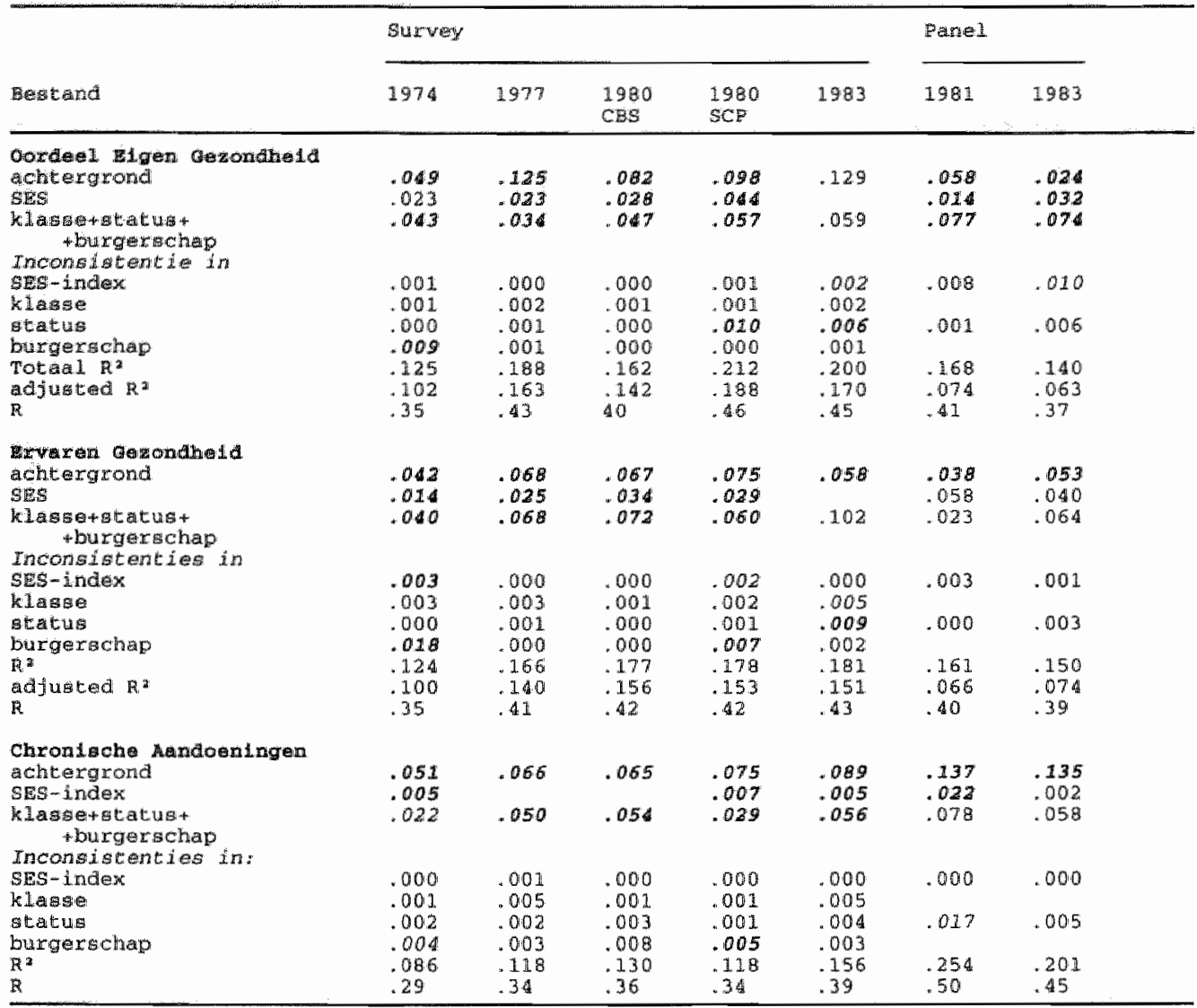

$p<.10 p<.05$ 


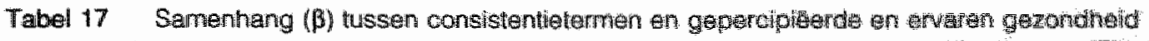

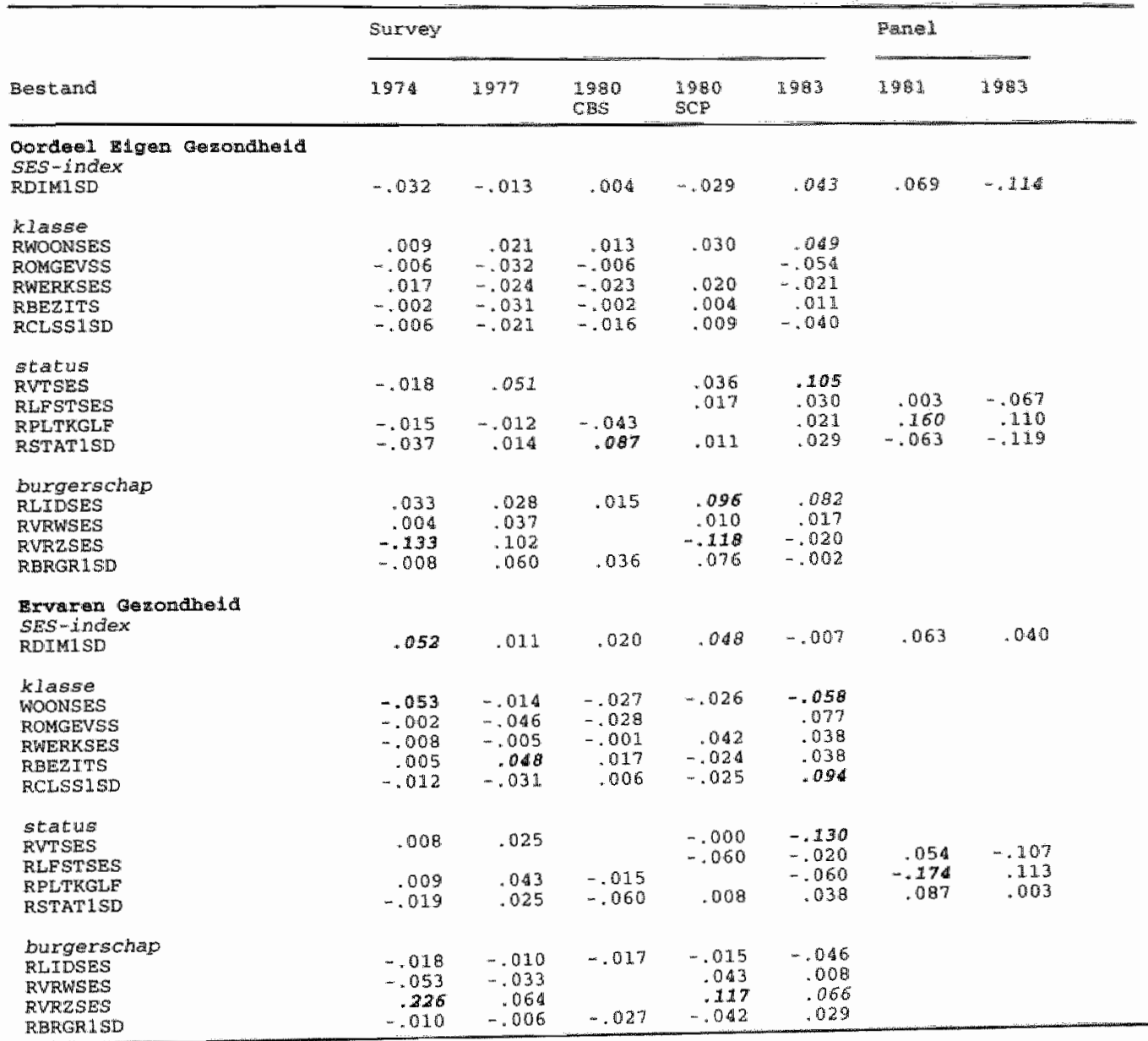


Tabel 18 Samenhang (b) tussen consistentie-termen en de aanwezighaid van chronische aandoeningen

\begin{tabular}{|c|c|c|c|c|c|c|c|}
\hline \multirow[b]{2}{*}{ Bestcand } & \multicolumn{5}{|c|}{ Suryey } & \multicolumn{2}{|l|}{ Panel. } \\
\hline & 1974 & 1977 & $\begin{array}{l}1980 \\
\mathrm{CBS}\end{array}$ & $\begin{array}{l}1980 \\
\$ C E\end{array}$ & 1983 & 1981 & 1983 \\
\hline 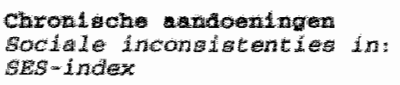 & $m .013$ & .111 & .074 & -.021 & .019 & -.067 & -.004 \\
\hline 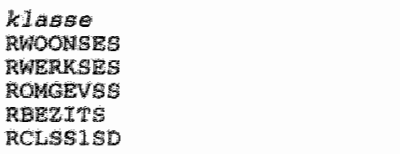 & $\begin{array}{r}.000 \\
-.046 \\
.035 \\
-.079 \\
-.029\end{array}$ & $\begin{array}{r}-.062 \\
.010 \\
-.177 \\
.063 \\
.140\end{array}$ & $\begin{array}{r}-.112 \\
.002 \\
.095 \\
.030 \\
-.057\end{array}$ & $\begin{array}{l}-.032 \\
-.015 \\
-.022 \\
-.144\end{array}$ & $\begin{array}{r}-.005 \\
.124 \\
.025 \\
.093 \\
.220\end{array}$ & & \\
\hline 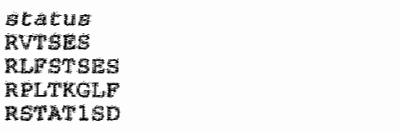 & $\begin{array}{l}.022 \\
.126 \\
.118\end{array}$ & $\begin{array}{r}.010 \\
.021 \\
.097\end{array}$ & $\begin{array}{r}.207 \\
-.089\end{array}$ & $\begin{array}{r}-.044 \\
.156 \\
.110\end{array}$ & $\begin{array}{l}-.097 \\
-.321 \\
-.111 \\
-.169\end{array}$ & $\begin{array}{r}-.451 \\
-.033 \\
.041\end{array}$ & $\begin{array}{l}-.379 \\
-.299 \\
-.129\end{array}$ \\
\hline $\begin{array}{l}\text { Durgerschap } \\
\text { RLIDSES } \\
\text { RVRWSES } \\
\text { RWRZEES } \\
\text { RERGR1SD }\end{array}$ & $\begin{array}{r}.034 \\
-.316 \\
.230 \\
-.102\end{array}$ & $\begin{array}{r}-.028 \\
.186 \\
.196 \\
-.018\end{array}$ & $\begin{array}{l}-.294 \\
-.220\end{array}$ & $\begin{array}{r}. .013 \\
.190 \\
.324 \\
.456\end{array}$ & $\begin{array}{r}-.075 \\
.144 \\
.033 \\
.+79\end{array}$ & & \\
\hline
\end{tabular}




\section{Curriculum Vitae}

De auteur van dit proefschrift is geboren te Amsterdam op 13 maart 1947. In 1967 behaalde hij het diploma gymnasium $\beta$ aan het toenmalige Berlage Lyceum (voorheen Comenus Lyceum) aldaar.

In datzelfde jaar begon hij met de studie Westerse Sociologie aan de Rijksuniversiteit Leiden. In 1974 werd het doctoraalexamen behaald met hoofdwalk sociologie en als belangrijkste bijvakken medische sociologie, methoden en technieken en algemene taalwatenschap.

Sinds juli 1974 is de auteur verbonden aan de vakgroep Medische Sociologie van de Rijksuniversiteit Limburg. Zowel in onderwijs als onderzoek gaat zijn belangstelling uit de maatschappelijke context van gezondheid en ziekte, met name naar de relatie tussen gezin en ziekte. Dat hilj daarbij graag iets verder kijkt dan het gezin alleen, daarvan getuigt dit proefschrift. 